\title{
CYP2D6 and CYP2C19 genotyping in psychiatry
}

Citation for published version (APA):

Koopmans, A. (2021). CYP2D6 and CYP2C19 genotyping in psychiatry: bridging the gap between practice and lab. [Doctoral Thesis, Maastricht University]. ProefschriftMaken. https://doi.org/10.26481/dis.20210512ak

Document status and date:

Published: 01/01/2021

DOI:

10.26481/dis.20210512ak

Document Version:

Publisher's PDF, also known as Version of record

\section{Please check the document version of this publication:}

- A submitted manuscript is the version of the article upon submission and before peer-review. There can be important differences between the submitted version and the official published version of record.

People interested in the research are advised to contact the author for the final version of the publication, or visit the DOI to the publisher's website.

- The final author version and the galley proof are versions of the publication after peer review.

- The final published version features the final layout of the paper including the volume, issue and page numbers.

Link to publication

\footnotetext{
General rights rights.

- You may freely distribute the URL identifying the publication in the public portal. please follow below link for the End User Agreement:

www.umlib.nl/taverne-license

Take down policy

If you believe that this document breaches copyright please contact us at:

repository@maastrichtuniversity.nl

providing details and we will investigate your claim.
}

Copyright and moral rights for the publications made accessible in the public portal are retained by the authors and/or other copyright owners and it is a condition of accessing publications that users recognise and abide by the legal requirements associated with these

- Users may download and print one copy of any publication from the public portal for the purpose of private study or research.

- You may not further distribute the material or use it for any profit-making activity or commercial gain

If the publication is distributed under the terms of Article $25 \mathrm{fa}$ of the Dutch Copyright Act, indicated by the "Taverne" license above, 
CYP2D6 and CYP2C19 genotyping in psychiatry

Bridging the gap between practice and lab

Anne Koopmans 
Printing: Proefschriftmaken.nl

Cover: Julianabrug te Curaçao by Anne Koopmans

ISBN: 978-90-77877-25-4

Publisher: Parnassia Groep, Den Haag

Copyright (c) 2021 A. Koopmans

No part of this thesis may be reproduced or transmitted in any form or by any means, without the prior permission of the author.

Part of the research described in this thesis was financially supported by ZonMw (The Hague, the Netherlands) and by the Parnassia Academy part of Parnassia Psychiatric Institute (The Hague, the Netherlands). Financial support for the publication and distribution of this thesis by the Parnassia Academy and Maastricht University is gratefully acknowledged. 


\section{CYP2D6 and CYP2C19 genotyping in psychiatry \\ Bridging the gap between practice and lab}

\section{Proefschrift}

Ter verkrijging van graad van doctor aan de Universiteit Maastricht op gezag van de Rector Magnificus Prof dr. Rianne M. Letschert volgens het besluit van het College van Decanen

In het openbaar te verdedigen op woensdag 12 mei 2021 om 14.00 uur

door Anne Bregje Koopmans 


\section{Promotores}

Prof. dr. P.N. van Harten

Prof. dr. H.W. Hoek (Rijksuniversiteit Groningen)

\section{Copromotor}

Dr. D.J. Vinkers

Beoordelingscommissie

Prof. dr. T.A.M.J. van Amelsvoort (voorzitter)

Prof. dr. W. Cahn (UMC Utrecht)

Prof dr. M.C. Marcelis

Prof. dr. C.W. Slotema (Erasmus Universiteit Rotterdam) 
Voor Ise en Kees 



\section{TABLE OF CONTENTS}

Chapter $1 \quad$ General introduction and outline of the thesis

Chapter 2 Meta-analysis of probability estimates of worldwide variation 25 of CYP2D6 and CYP2C19

Chapter 3 CYP2D6 and CYP2C19 genotyping in psychiatric patients on psychotropic medication in the former Dutch Antilles

Chapter $4 \quad$ No effect of dose adjustment to the CYP2D6 genotype in patients with severe mental illness

Chapter 5 Proxy WHODAS 2.0 is clinically useful for assessing psychosocial functioning in severe mental illness

Chapter 6 Summary of main findings and general discussion

Chapter $7 \quad$ Impact of the thesis on the scientific and social community

Addendum Nederlandse samenvatting

List of abbreviations

References

Supplemental material

Dankwoord 203

Curriculum Vitae 

De mensen? Er bestaan er geloof ik zes of zeven. Die heb ik jaren geleden eens gezien. Maar je weet nooit waar je ze kunt vinden. De wind jaagt ze in het rond. Ze hebben geen wortels, dat is erg lastig voor ze.

(De bloem uit De Kleine Prins) 



\section{CHAPTER 1}

General introduction and outline of the thesis 

Patient M. is a 27-year-old man. Three years after he had to interrupt his high school education because of cognitive problems, he was diagnosed with schizophrenia. He was then 20 years old. At that time, he was single and working as a mailman. After being admitted to a psychiatric hospital because of screaming at night in the streets, he was prescribed haloperidol (4 mg/day) which had a good effect on his delusion of being poisoned. However, he developed parkinsonism, presenting as walking slowly without arm swing, rigidity, lack of facial expression and a monotonous voice. In the next 3 years, he switched to risperidone ( $4 \mathrm{mg} /$ day), but the parkinsonism persisted although it was a little less than with haloperidol. However, he gained $10 \mathrm{~kg}$ in weight. He lost his job, changed his day and night rhythm, and started to isolate himself. These behaviors were indicated as negative symptoms as a sign of schizophrenia, which made him and his psychiatrist decide to switch to 15 mg/day of aripiprazole. The switch led to psychotic symptoms again and he had to be re-admitted to hospital. There he participated in a prevalence study on CYP enzymes, which revealed he was a poor metabolizer of CYP2D6 (genotype CYP2D6*4/*4). Because haloperidol, risperidone and aripiprazole are all metabolized by the CYP2D6 enzyme, for years he had been given relatively high dosages of antipsychotic medication to control his psychoses. Based on the Dutch KNMP guideline, $2 \mathrm{mg}$ /day of haloperidol was then prescribed, which effectively reduced his psychotic delusions. He did not develop any parkinsonism and was clearly more active. His earlier negative symptoms were now interpreted as secondary negative symptoms caused by the relatively high dosage of haloperidol or risperidone.

This vignette describes how a patient with schizophrenia can go through a long process of trying different medications, sometimes with benefits, but often experiencing life-influencing side effects (1). It also shows that CYP genotyping can provide additional treatment strategies, for example, lowering a dose of an effective antipsychotic drug. 


\section{Chapter 1}

Prescribing antidepressant or antipsychotic medication in psychiatry can be a difficult process, in which possible benefits have to be carefully weighed against frequently occurring side effects. Medication history, age, physical parameters, and other variables are considered in the process of deciding on the appropriate medication. However, strong personalized predictors that could guide the pharmacotherapy are often lacking. Thus, many patients experience the search for the most appropriate medication as a process of trial and error. Genetic factors may play a major role in a drug's effectivity and side effects. It is estimated that one-quarter of the variability in drug response is due to an individual's genotype (2). Of specific interest are the activity of the CYP2D6 and CYP2C19 enzymes because 50-75\% of all antidepressant and antipsychotic drugs are metabolized by one of these two enzymes (https:/www.gipdatabank.nl/servicepagina/open-data) $(3,4)$. Multiple studies show that the activity of the CYP2D6 and CYP2C19 enzymes is related to the prevalence of side effects and to treatment response (5-7).

What would happen if we were to choose and optimize the dose of psychiatric medication according to a CYP genetic profile?

Studies on the Caribbean island of Curaçao show there is a relatively high prevalence of drug-induced movement disorders, such as parkinsonism, tardive dyskinesia, and especially tardive dystonia, in patients with mental disorders (8). A large percentage of the population also suffers from metabolic syndrome (9), and in some subpopulations in the Caribbean region, the prevalence of poor metabolizers of CYP2D6 is extremely high ( 10\%) (10).

Until now, we did not know what the prevalence of non-normal CYP metabolizers was in this island population. In European populations, the prevalence of slow and ultrarapid metabolizers is $5 \%$ and $3 \%$, respectively (11). Knowing the prevalence of non-normal CYP metabolizers in the island's population is of major clinical importance, especially if there is a clear relationship between the prevalence of nonnormal metabolizers and the occurrence of side effects and treatment resistance. Genotyping could offer the possibility of preventing side effects by indicating a different type of antipsychotic or antidepressant medication, or a different dose, according to an individual's genetic profile. A better response to prescribed medication would improve daily functioning and quality of life. Given these major benefits, the cost of genotyping will be worthwhile.

In this thesis I investigate whether CYP genotyping improves treatment outcomes in psychiatric patients. First, I provide a systematic review and meta-analysis to report a worldwide epidemiological perspective. Thereafter, I will focus on patients with severe mental illness on Curaçao and whether genotyping leads to healthcare benefits. 
CYP450

There is tremendous variation in the speed at which individuals metabolize medication into inactive compounds in the liver. The effect of most medication is determined by the rate at which it is metabolized.

The so-called 'phase I reaction' by the cytochrome P450 (CYP) is responsible for the metabolization of lipophilic medication into more hydrophilic compounds, which are then excreted via the kidneys $(12,13)$. There are many factors influencing the speed at which the CYP450 metabolizes, for example, diet, medication, alcohol, drugs, smoking, pregnancy and age (14-19).

However, one of the most important factors is an individual's combination of genetic variants or alleles (denoted by *). These alleles can be determined by collecting blood or specimens and detecting insertions, deletions, and gene rearrangements in their DNA.

Depending on the number of functional alleles, genotypes can be translated into a predicted phenotype. In ascending metabolization rate, they can be divided into poor metabolizers (PM), intermediate metabolizers (IM), normal metabolizers (NM, also referred to as extensive metabolizers EM) and ultrarapid metabolizers (UM). Because the serum level of medication is related to the activity of the enzyme, which is partly determined by the individual genotype, the same dosage will lead to a higher serum level in PMs and IMs than in NMs, and to a lower serum level in UMs than NMs (Figure 1). The serum level is often related to the effectivity of the drug and to the risk of dose-related side effects (20-25). 


\section{Chapter 1}

Figure 1.

Schematic adaptation of doses due to genotypes causing differences in drug metabolism and elimination (26).

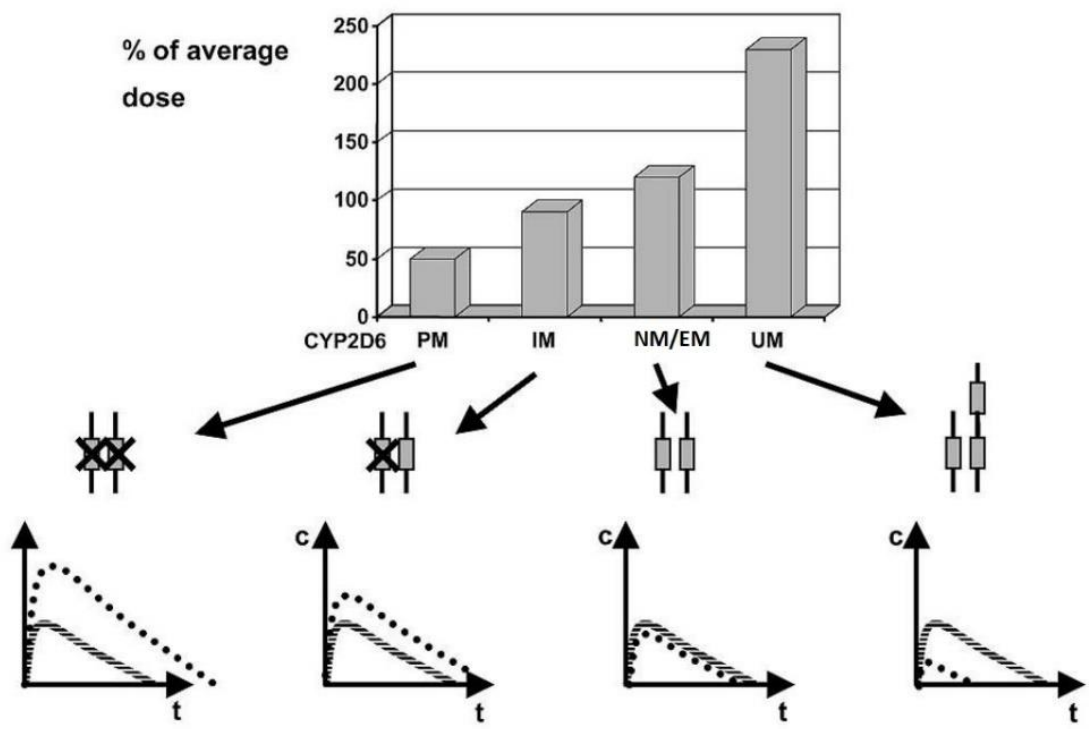

PM=poor metabolizer, $I M=$ intermediate metabolizer, NM/EM=normal/extensive metabolizer, UM=ultrarapid metabolizer $c=$ concentration of drugs in blood, $t=$ time in hours

There are eight gene families (CYP1A2, CYP2B6, CYP2C8, CYP2C9, CYP2C19, CYP2D6, CYP2E1 and CYP3A4) relevant to pharmacotherapy; each is responsible for the metabolism of a different group of medications. Most medication is mainly metabolized by one enzyme, but the process can be taken over by other enzymes if a certain enzyme is not functioning or is occupied with the metabolization of other biochemicals.

The CYP2D6 and CYP2C19 enzymes are specifically relevant to the metabolism of psychiatric drugs (27-32). Both genes are highly polymorphic, which means that there are many allelic variants accounting for the enzyme's functionality. So far, more than 100 variants of the CYP2D6 gene and more than 50 variants of the CYP2C19 gene have been identified. Each allelic variant has its own properties and the functionality of the CYP2D6 and CYP2C19 alleles are listed in PharmVar (https://www.pharmvar.org/gene). The combination of alleles is translated into a predicted phenotype as shown in Tables 1 and $2(33,34)$. 
Table 1. Allele combinations of CYP2D6 leading to predicted phenotypes

\begin{tabular}{|l|l|l|l|l|l|l|l|l|l|l|l|l|l|}
\hline Allele & *1 & *2 & *3, & *4 & *5 & *6 & *7 & *8 & *9 & *10 & *17 & *29 & *41 \\
\hline *1 & NM & NM & IM & IM & IM & IM & IM & IM & NM & NM & NM & NM & NM \\
\hline *2 & & NM & IM & IM & IM & IM & IM & IM & NM & NM & NM & NM & NM \\
\hline *3 & & & PM & PM & PM & PM & PM & PM & IM & IM & IM & IM & IM \\
\hline *4 & & & & PM & PM & PM & PM & PM & IM & IM & IM & IM & IM \\
\hline *5 & & & & & PM & PM & PM & PM & IM & IM & IM & IM & IM \\
\hline *6 & & & & & & PM & PM & PM & IM & IM & IM & IM & IM \\
\hline *8 & & & & & & & PM & PM & IM & IM & IM & IM & IM \\
\hline *9 & & & & & & & & & IM & IM & IM & IM & IM \\
\hline *10 & & & & & & & & & & IM & IM & IM & IM \\
\hline *17 & & & & & & & & & & & IM & IM & IM \\
\hline *29 & & & & & & & & & & & & IM & IM \\
\hline *41 & & & & & & & & & & & & & IM \\
\hline
\end{tabular}

PM=poor metabolizer, IM=intermediate metabolizer, $N M=$ normal metabolizer,

UM=ultrarapid metabolizer

${ }^{1}$ The CYP2D6 UM variant is a result of 1 to 10 gene duplications

Table 2. Allele combinations of CYP2C19 leading to predicted phenotypes

\begin{tabular}{|c|c|c|c|c|}
\hline Allele & *1 & *2 & *3 & *17 \\
\hline *1 & NM & IM & IM & UM \\
\hline *2 & & PM & PM & IM \\
\hline *3 & & & PM & IM \\
\hline *17 & & & & UM \\
\hline
\end{tabular}

PM=poor metabolizer, IM=intermediate metabolizer, $N M=$ normal metabolizer, UM=ultrarapid metabolizer 


\section{Chapter 1}

\section{Drug interactions}

When prescribing medication metabolized by CYP2D6 or CYP2C19 enzymes, drug interactions must also be considered. There are two possibilities by which comedication (medication taken at the same time) can influence the speed at which the enzyme metabolizes. Inhibiting medication competes with the substrate drugs or inactivates the metabolizing enzyme and thus lowers the level of metabolism of the substrate drug, which can result in toxic serum levels. Inducing medication increases the rate of metabolization by the enzyme, which can result in sub-therapeutic serum levels. One important combination seen in psychiatry is a prescription for omeprazole (for reducing stomach acid), which inhibits the CYP2C19 activity, with a selective serotonin reuptake inhibitor (SSRI), which is metabolized by the CYP2C19 enzyme (e.g. escitalopram, citalopram and sertraline. Another common combination is that of a CYP2D6-inhibiting antidepressant (e.g. fluoxetine or bupropion) prescribed with an antipsychotic which is metabolized by the CYP2D6 enzyme (e.g. aripiprazole or risperidone).

\section{CYP2D6}

In 1988 CYP2D6 was determined to be the enzyme responsible for inter-individual differences in response to debrisoquine (an antihypertensive drug) and sparteine (an antiarrhythmic) (35). Later, it was discovered that this enzyme was metabolizing $20 \%$ of all medication prescribed (36). It was mapped to the 22q13.1 chromosome and the first genetic variations were reported in 1990 (37,38). Medications metabolized by CYP2D6 include first- and second-generation antipsychotics, SSRIs, and tricyclic antidepressants (TCA) (Table 3). See also https://cpicpgx.org/genes-drugs.

In patients with schizophrenia, drug-induced movement disorders are a major side effect of antipsychotic medication. These disorders can be divided into acute (starting shortly after taking a dopamine-blocking agent) and tardive (arising months to years after using dopamine-blocking agents) syndromes. The most important acute syndromes are parkinsonism, akathisia and acute dystonia, while the tardive syndromes are tardive dyskinesia and tardive dystonia. Because of the symptoms' visibility and the impaired movement control, these medications are linked to great impairment and poorer treatment adherence (39). Drug-induced movement disorders are often dose-dependent and occur above a certain level (78\%) of dopamine D2 receptor occupancy $(40,41)$. They are found to be more prevalent in PMs and IMs. However, clinical response to antipsychotic medication is significantly increased if D2 occupancy exceeds 65\% (41), and UMs only benefit from higher doses of antipsychotics than those given to NMs (22). 
A meta-analysis of patients with schizophrenia has shown an increased risk of druginduced tardive dyskinesia and parkinsonism in patients with a non-NM genotype on typical antipsychotic medication (6). The costs of treatment and length of hospitalizations of PMs and UMs are, on average, longer than for IMs and NMs $(5,42)$. In another cost analysis of patients with schizophrenia in Denmark, it was found that total health costs among all extreme metabolizers (PM+UM) were $177 \%$ higher than among the NMs, and that genotyping could lead to lower treatment costs (7). Recently, a study of patients with schizophrenia showed that those who had pharmacogenetic testing prior to a switch or to start of antipsychotics showed less side effects than patients receiving treatment as usual, even though the effects were minimal and not significant (43). The Pharmacogenetics Working Group guidelines from the Royal Dutch Association for the Advancement of Pharmacy recommend genotype-guided dose adjustments for patients with a non-normal CYP2D6 genotype, and use of haloperidol, risperidone, aripiprazole and zuclopenthixol (44).

TCAs have a narrow therapeutic window to reach maximal efficiency and a minimum number of side effects. Optimal plasma concentrations have been defined for their use. PMs and IMs are thought to be more vulnerable for side effects and treatment failure than NMs. Although there is limited evidence of the benefits of genotyping on efficacy and toxicity, clinical guidelines recommend dose adjustments in patients on SSRIs or TCAs with non-NM genotypes (45-47). 


\section{Chapter 1}

Table 3. Antidepressant and antipsychotic medication metabolized by CYP2D6 or CYP2C19"

CYP2D6

CYP2C19

\begin{tabular}{|c|c|c|}
\hline \multicolumn{3}{|l|}{ Antipsychotics } \\
\hline aripiprazole* & $x$ & \\
\hline Brexpiprazole* & $x$ & \\
\hline clozapine & $x$ & \\
\hline haloperidol* & $x$ & \\
\hline perphenazine & $x$ & \\
\hline pimozide* & $x$ & \\
\hline risperidone* & $x$ & \\
\hline zuclopenthixol* & $x$ & \\
\hline \multicolumn{3}{|l|}{ Antidepressants } \\
\hline amitriptyline* & $\mathrm{x}$ & $\mathrm{x}$ \\
\hline citalopram* & & $x$ \\
\hline clomipramine* & $x$ & $x$ \\
\hline desipramine* & $x$ & \\
\hline duloxetine & $x$ & \\
\hline escitalopram* & & $\mathrm{x}$ \\
\hline fluoxetine & $x$ & \\
\hline fluvoxamine & $x$ & \\
\hline imipramine* & $x$ & $\mathrm{x}$ \\
\hline mirtazapine & $x$ & \\
\hline nortriptyline* & $x$ & \\
\hline paroxetine* & $x$ & \\
\hline sertraline* & $x$ & $\mathrm{x}$ \\
\hline venlafaxine* & $x$ & \\
\hline vortioxetine & $x$ & \\
\hline
\end{tabular}

\# Table 3 is based on information from the PharmKGB Clinical Guideline Annotations, consulted 5 November 2020. See also https://www.pharmgkb.org/

*Therapeutic dose recommendations 


\section{CYP2C19}

Medications metabolized by CYP2C19 include SSRIs and TCAs (Table 3) The gene was mapped to the $10 \mathrm{q} 24$ chromosome and the first genetic variations were reported in 1995 (48). Multiple studies have shown a relationship between the CYP2C19 genotype and plasma concentrations of TCAs; extreme metabolizers have increased risk for side effects and treatment failure (49-52). Treatment effects of SSRIs are less dose-dependent than for antipsychotics and there is conflicting evidence on the influence of CYP2C19 on response and toxicity (53). Nonetheless, a few studies show an overall improvement of depressive symptoms in patients on genotype-guided treatment (54-56).

\section{Curaçao}

Both CYP2D6 and CYP2C19 genes are highly polymorphic and the prevalence of the different CYP alleles varies widely across ethnic groups (57). It is speculated that because CYP2D6 has a high affinity with alkaloids, it may have played a role in detoxification when people had to eat toxic plants during periods of starvation. It is thought that selection pressure favored survival of ultrarapid metabolizers in, for example, Ethiopia, where the population expanded rapidly between 10,000-20,000 years ago (58). Research into CYP enzymes in Latin America also shows large interethnic differences, with the prevalence of CYP2D6 PM varying from 0-10.2\% (10).

Until now, the prevalence of CYP2D6 and CYP2C19 in the group of Caribbean islands that made up the former Netherlands Antilles was not known (59). The population of Curaçao originated from Western Africa and has admixed with European immigrants and Native South Americans (60). Together with Aruba and Bonaire, Curacao forms the 'ABC' islands. Until 2010, these islands (together with St Maarten, Saba and St. Eustatius) formed the Netherlands Antilles. Curaçao is one of the western Leeward Antilles in the Caribbean and the island now has about 156,223 inhabitants (61). In January 2020, there are some 166,265 immigrants (first- and second generation) from the former Netherlands Antilles living in the Netherlands (62). This group, and particularly the second-generation immigrants, has a high risk of developing psychotic disorders and are more often retained for compulsory admission to a psychiatric hospital $(63,64)$.

The healthcare system on Curaçao is based on the Dutch healthcare system. All inhabitants have access to high standard healthcare and have medical insurance coverage. However, the Caribbean lifestyle is characterized by sedentary behavior and an unhealthy diet, so that obesity and metabolic syndrome are both widespread problems. The whole Caribbean region is currently suffering from an obesity and diabetes epidemic (9). De Caluwe has recently shown that especially female 


\section{Chapter 1}

Caribbean patients with severe mental illness (SMI) are at risk for metabolic syndrome, with a prevalence of $63.6 \%$ vs. $33.1 \%$ in other ethnicities (9). A high prevalence of dose-dependent movement disorders, especially dystonia, was also found by a naturalistic cohort study in an 18-year follow-up of patients with schizophrenia on Curaçao $(8,65,66)$. If the prevalence of slow or rapid metabolizers in this population is related to their side effects and treatment resistance, it would be a clinically important factor. We therefore wanted to determine if the prevalence of poor-, intermediate- and ultrarapid metabolizers is different than in European populations, for example. Since some studies have also shown a correlation between CYP activity and the occurrence of schizophrenia (67), we decided to investigate if CYP prevalence differs between the Antillean population with and without psychiatric disorders. We studied both populations on the island of Curaçao, but also collected DNA samples from sputum of immigrants from the former Netherlands Antilles at events they held in the Netherlands. To evaluate the health benefit to general practice, we have sent our genotyping results to general practitioners in the Netherlands.

\section{Severe mental illness and measures of functioning}

Patients with severe mental illnesses (SMI) are known to suffer particularly from side effects and poor medication response (1,68-70). A study in 1827 patients showed that over $90 \%$ reported at least one drug-induced side effect and high levels of distress (1). When patients suffer from one movement disorder, the chances of developing a second or third movement disorder are increased (71). These side effects impair their psychosocial functioning and quality of life (1). Genotyping in patients with SMI can help personalize treatment, and potentially reduce side effects and levels of distress in slower metabolizers; it can increase treatment effects in rapid metabolizers; and eventually lead to better psychosocial functioning and better quality of life (72). We therefore selected a group of 45 patients with SMI and a nonnormal metabolizer profile from Curaçao and adjusted their medication to better fit their CYP2D6 profile. We investigated if this intervention influenced their side effects, treatment response and daily functioning.

The term 'Severe Mental Illness' was introduced by the USA Substance Abuse and Mental Health Services Administration to differentiate between psychiatric patients with and without problems in daily functioning (73). Central to the monitoring of their recovery process is the measurement of patients' psychosocial functioning. This can be measured using the WHODAS 2.0 questionnaire, introduced in DSM-5. It has been validated across different cultures, and can measure function in six domains. Although the patient version has shown reliable clinical outcomes, there was limited evidence so far for use of the proxy version. We used the proxy version in our SMI 
population to see if it could parry problems with cognitive deficits and lack of disease insight, and whether it was useful for measuring disease outcomes (74-76).

\section{Outline of this thesis}

Although there is a wealth of information and clinical guidelines recommend genotype-guided dose adjustments, pharmacogenetics is still not widely used. The work in this thesis aimed to bridge the gap between the scientific evidence for pharmacogenetic testing and clinical psychiatric practice (77).

In chapter 2 we review the literature on CYP2D6 and CYP2C19 genotypes worldwide. We included studies which fulfil criteria for use in clinical practice and estimated the probability of an individual having a non-NM metabolizer profile.

In chapter 3 we describe how we determined the prevalence of CYP2D6 and CYP2C19 genotypes in patients with severe mental illnesses (SMI) and in volunteers from the general population in the former Netherlands Antilles. This meant we could analyze the data to detect differences in prevalence between patients with SMI and the general population.

In chapter 4 we assess the clinical utility of CYP2D6 genotyping by prospectively investigating the influence of dose adjustments on psychiatric symptoms, side effects, and functioning in patients with SMI.

In chapter 5 we describe how we measured the psychosocial functioning of patients with $\mathrm{SMI}$ and assess the relationship with their psychiatric symptoms, side effects, and quality of life. We used the (proxy) WHODAS 2.0 questionnaire, which was adopted by DSM- 5 .

Finally, in the general discussion (chapter 6), our findings are placed in a broader perspective, focusing on arguments for and against genotyping in psychiatric patients. The chapter concludes with possible directions for future research. 



\section{CHAPTER 2}

\section{Meta-analysis of probability estimates of worldwide variation of CYP2D6 and CYP2C19}

Anne B. Koopmans

Mario H. Braakman

David J. Vinkers

Hans W. Hoek

Peter N. van Harten 


\section{Chapter 2}

\section{Abstract}

Extensive migration has led to the necessity of knowledge regarding the treatment of migrants with different ethnical backgrounds. This is especially relevant for pharmacological treatment, because of the significant variation between migrant groups in their capacity to metabolize drugs. For psychiatric medications, CYP2D6 and CYP2C19 enzymes are clinically relevant. The aim of this meta-analysis was to analyze studies reporting clinically useful information regarding CYP2D6 and CYP2C19 genotype frequencies, across populations and ethnic groups worldwide. To that end, we conducted a comprehensive meta-analysis using Embase, PubMed, Web of Science and PsycINFO (>336 000 subjects, 318 reports). A non-normal metabolizer (non-NM) probability estimate was introduced as the equivalent of the sum-prevalence of predicted poor, intermediate and ultrarapid metabolizer CYP2D6 and CYP2C19 phenotypes. The probability of having a CYP2D6 non-NM predicted phenotype was highest in Algeria (61\%) and lowest in Gambia (2.7\%) while the probability for CYP2C19 was highest in India (80\%) and lowest in countries in the Americas, particularly Mexico (32\%). The mean total probability estimates of having a non-NM predicted phenotype worldwide were $36.4 \%$ and $61.9 \%$ for CYP2D6 and CYP2C19, respectively.

We provide detailed tables and world maps summarizing clinically relevant data regarding the prevalence of CYP2D6 and CYP2C19 predicted phenotypes and demonstrating large inter-ethnic differences. Based on the documented probability estimates, pre-emptive pharmacogenetic testing is encouraged for every patient who will undergo therapy with a drug(s) that is metabolized by CYP2D6 and/or CYP2C19 pathways, and should be considered in case of treatment resistance or serious side effects. 


\section{Introduction}

Migration is a growing global phenomenon so that Western-trained psychiatrists are increasingly treating migrants with different cultural and ethnic backgrounds(78). In the psychopharmacological treatment of migrants, variation in drug metabolism is an important aspect that must be taken into account (79). In psychiatry, CYP2D6 and CYP2C19 are important drug metabolizing enzymes (27-32). For example, drugs that are metabolized by CYP2D6 include first and second generation antipsychotics, selective serotonin receptor inhibitors, and tricyclic antidepressants (29). Among those metabolized by CYP2C19 are benzodiazepines, selective serotonin receptor inhibitors, and tricyclic antidepressants (29). Individuals' genetic variation is the most important factor influencing the kinetics of drug metabolism, and thus may contribute to intolerability-related discontinuation or treatment failure (80).

The outcome of a pharmacogenetic test (i.e. a patient's genotype, sometimes also referred to as diplotype) can be translated into a predicted phenotype. A combination of functional and non-functional alleles are responsible for the activity of the enzymes. There are four phenotype groups: poor (PM), intermediate (IM), normal (NM) (previously referred to as 'extensive'), and ultrarapid metabolizers (UM), which are used to predict whether and how well a drug is metabolized. The same drug dosage may lead to a higher plasma level in PMs and IMs, compared to NMs, because of slower drug clearance, while UMs may have lower plasma levels than NMs because of a higher rate of drug clearance. Plasma levels are often related to the efficacy of a drug and the risk of dose-related side effects, with more severe side effects found in PMs and IMs than NMs (20-25).

The prevalence of CYP polymorphisms also varies considerably across ethnic groups and plays a major role in inter-individual and inter-ethnic differences in drug metabolism and response (57). For example, in European populations, just 2-3\% of the population have a CYP2D6 UM profile, compared to $20-29 \%$ in East-African populations (11,81). In contrast, CYP2C19 PMs are considerably more frequent in Asians ( 12\%) than in Europeans ( 2\%) (82). Some allelic variants such as CYP2D6*40 and $* 45$ are only seen in specific populations $(83,84)$.

The Clinical Pharmacogenetics Implementation Consortium (CPIC) has published guidelines with recommendations for drug choice and dosage based on phenotype predictions $(44,46,47,85)$.

Other groups, including the Royal Dutch Association for the Advancement of Pharmacy - Pharmacogenetics Working Group (DPWG), have also published guidelines (information for both organizations is available through the Pharmacogenomics Knowledge Base at https://www.pharmgkb.org/guidelines). CYP2D6 and CYP2C 19 allele frequency information has been compiled by CPIC and is available at https://www.pharmgkb.org/page/cyp2d6RefMaterials. Gaedigk et al, 


\section{Chapter 2}

Fricke-Galindo et al and Llerena et al have described CYP2D6 and CYP2C19 phenotype prediction from genotype across world populations $(11,82,86)$.

Although there is a wealth of information, pharmacogenetics is still not being widely used in clinical practice. Several studies have shown the relationship between CYP activity, blood serum levels, and side-effects, but there have been few studies on clinical effectivity. Most of the studies are cross-sectional and observational, while prospective studies are often underpowered $(7,27,87,88)$. For some drugs, clinicians are used to working with therapeutic drug monitoring and they may prefer this over genotyping.

Another reason is the lack of education of practitioners on this topic and the belief that pharmacogenetics "is not ready" for use in daily clinical practice (89-92). Despite these barriers, pharmacogenetics is increasingly being adopted by major health centers, and the body of literature in support of pharmacogenetic testing is growing $(5,7,42,87,93-96)$.

The aim of our meta-analysis was to assess studies reporting clinically useful information about CYP2D6 and CYP2C19 genotype frequencies across populations and ethnic groups worldwide. We introduce the concept of the non-normal metabolizer (non-NM) probability estimate, for which we calculated the sumprevalence of a population for having a poor, intermediate or ultrarapid CYP2D6 or CYP2C19 predicted phenotype. The sum-prevalence of these three predicted phenotypes presents a single measurement for non-normal metabolism in the populations of interest. It is defined as the equivalent of the prevalence of PM + IM + UM predicted phenotypes of the enzyme in percentages.

\section{Methods}

For this study we followed the checklist in the Preferred Reporting Items for Systematic Reviews and Meta-Analyses (PRISMA) statement $(97,98)$. The protocol for the current systematic review was not registered prior to the review.

\section{Review of literature}

We conducted a literature review using the Embase, PubMed, Web of Science and PsycINFO databases (1990-2019). The terms 'CYP2D6' AND/OR 'CYP2C19' AND 'prevalence' OR 'ethnicity' OR 'race' AND 'healthy subject' OR 'normal control', and variations on these terms and the names of different countries and continents were used in all fields. The last search was conducted on July 3rd, 2019. 
Our inclusion criteria were: (1) CYP2D6 or CYP2C19 allele frequencies from original data were reported; (2) the evaluated subjects did not have a specific disease (controls from case-control studies were included); (3) ethnicity was reported; (4) the article was published in English; (5) a minimum of 20 participants was investigated. If only an abstract was available, the article was included if all the above information was available and (6) in order to be able to calculate a probability estimate, it was necessary to assess a minimum number of non-functional alleles and alleles with decreased function as well as a number of gene duplications. The genotyping assay included at least the following allelic variants: CYP2C19*2 and ${ }^{*} 17$ in Africans, Americans, Europeans, Middle Easterners, Central/ South East-Asians and African Americans. CYP2C19*2, *3 and *17 in Oceanians and CYP2C19*2 and *3 in East Asians. CYP2D6*2, *5, *17, *29 and *41 in Africans. CYP2D6*2 and *4 in Americans. CYP2D6*2 and * 10 in East Asians. CYP2D6*2, 4 and *41 in Europeans. CYP2D6*2, *4, ${ }^{*} 10$ and $* 41$ in Middle Easterners and Central/South East-Asians. CYP2D6*5 in Oceanians. CYP2D6*2, *4* 17 and *29 in African Americans.

An eligibility assessment was performed independently in a standardized manner by A.K. and D.V. The first screening was based on the article abstracts; the next selection was based on the full text. Disagreements between the two reviewers were resolved by discussion to reach a consensus.

\section{Data extraction}

The data were independently extracted from the studies by two investigators (A.K. and P.B.) and randomly checked by two investigators (D.V. and A.K.). For some studies, authors were contacted for clarification of the data.

Information was extracted from each study as follows: (1) ethnicity of the participants; (2) definition of ethnicity (self-reported or genetic ancestry); (3) country of the studied population; (4) number of study participants; (5) study design (prevalence study, case-control study, experimental study); (6) allele frequencies; (7) diplotype frequencies; (8) predicted phenotype frequencies.

Star $\left(^{*}\right)$ alleles were assigned according to the Pharmacogenetic Variation (PharmVar) Consortium at https://www.pharmvar.org $(99,100)$.

\section{Ethnicity and Geographical regions}

To be able to compare outcomes with previous meta-analyses, reported ethnicity was assigned to geographic regions, as done in previous meta-analysis about this subject, according to the Human Genome Diversity Project (101). Seven major 


\section{Chapter 2}

regions were considered: Africa, Americas (including Latino Americans and indigenous inhabitants of North America and Canada), East Asia, Europe (including North Americans and Canadians), the Middle East, Oceania and Central/Southeast Asia; with one exception, namely that African-Americans were listed separately from Africans (11). Here, the frequencies of PM, IM, EM, and UM are reported by ethnicity, whereas the probability estimates of being a non-normal metabolizer are reported by country. In many studies, these two factors -country and ethnicity- overlap, but for some studies we had to assign an ethnicity to a country to be able to show the information in world maps (i.e. the two factors were not distinguished). The origin of the investigated ethnicity determined the country and region to which a population was assigned. An exception was made for Latin America, in which the population is an admixture of multiple origins (e.g. European, African, Asian and Amerindian) and no clear lineages can be determined; they were all considered as populations of the Americas and determined as belonging to the country they live in $(102,103)$. For some ethnicities we could not determine a country of origin (for example, East Asians or Europeans) so we have indicated them as 'missing' in the figures.

\section{Translation of genotype into phenotype}

For each geographical region, the mean frequency of alleles was determined. In order to predict CYP2D6 and CYP2C19 phenotype frequencies from genotype data we applied the activity score (AS) system to both genes (the AS system is widely used for CYP2D6 and was adapted to CYP2C19 to facilitate the translation process) (33). Briefly, a normal function allele was valued as 1 , decreased function alleles as 0.25 or 0.5 , a non-functional allele as 0 , and increased function allele as 1.5. Gene duplications received double the value of their singleton counterparts. Homozygous carriers of non-functional alleles were classified as PMs (AS $=0)$. Carriers with one functional or decreased function allele and one non-functional allele, and those carrying two decreased function alleles were classified as IMS (AS = 0.25-1) (33). Homozygous carriers of normal function alleles, and heterozygous carriers with one decreased function and one normal function allele, were classified as NMs (AS = 1.25-2.25) (33). Carriers of one or more increased function alleles, and carriers of a duplication or multiplication of a functional allele, were classified as UMs (AS >2.25) (33) (https://cpicpgx.org/resources/term-standardization/). CYP2C19 rapid and ultrarapid metabolizers were pooled and analyzed as UMs. The functionality of the CYP2D6 and CYP2C19 alleles was classified as listed by PharmVar in Table 1.

In this meta-analysis, we applied strict criteria. To maximize the accuracy of the frequencies of the predicted phenotypes, we only predicted a phenotype if the original publication reported a minimum of non-/decreased function alleles and the assays included tests for gene duplications. Since the prevalence of alleles differed 
greatly per region, we used criteria specific for each geographical region. Alleles more prevalent than 0.05 (5\%) in the major region (Table 2) had to be investigated in the countries within that region to be included in the phenotype predictions.

Table 1. Functionality of CYP2D6 and CYP2C19 alleles (https://www.pharmvar.org/gene)

\begin{tabular}{|c|c|c|}
\hline & CYP2D6 & CYP2C19 \\
\hline 0 & $\begin{array}{l}* 3-* 8, * 15, * 18, * 31, * 36, * 47, \\
* 51, * 56, * 57, * 62, * 92, * 100 \text { and } \\
* 101\end{array}$ & $\begin{array}{l}* 2, * 3, * 4, * 5, * 6, * 7, * 8, * 23 \text { and } \\
\star 24\end{array}$ \\
\hline $0.25-0.5$ & $\begin{array}{l}* 9, * 10, * 17, * 29, * 41, * 49, * 50, \\
* 54, * 55, * 59 \text { and } * 72\end{array}$ & $* 9, * 10, * 12, * 16, * 25$ and $* 27$ \\
\hline 1 & $\begin{array}{l}* 1, * 2, * 27, * 39, * 45, * 46 \text { and } \\
* 48\end{array}$ & $* 1, * 13, * 15$ and $* 18$ \\
\hline 1.5 & $* 53$ & $* 77$ \\
\hline Unknown & $\begin{array}{l}{ }^{*} 43,{ }^{*} 60, * 65, * 82, * 84, * 85 \text { and } \\
* 86\end{array}$ & \\
\hline
\end{tabular}

\section{Calculations and statistics}

All analyses were performed with IBM SPSS Statistics Version 25. If only diplotypes were reported, single allele frequencies were calculated. If only single allele frequencies were reported, diplotype frequencies were calculated using the Hardy Weinberg Equilibrium (HWE) $\left(p^{2}+2 p q+q^{2}=1\right)$. For studies that did not report the prevalence of $C Y P 2 D 6^{*} 1$, the allele frequency was calculated as $100 \%$ minus the sum of variants(11). The diplotypes were translated into predicted phenotypes according to the CPIC.

We introduce here the concept of the non-normal metabolizer (non-NM) probability estimate. It is defined as the sum of the prevalence of PM + IM + UM predicted phenotypes of the enzymes CYP2D6 or CYP2C19 in percentages. Thus, it is equivalent to the prevalence (as percentage) of all the non-normal phenotypes in a population. We use the term probability estimate exclusively in this sense and it is in fact a proportion of the possible outcomes in a population. It is equal to $100 \%$ minus the $\%$ of NM in a given population.

The studies were weighted by sample size (number of participants) when we calculated the mean predicted phenotypes per country and ethnicity. 


\section{Chapter 2}

\section{Results}

Of the 2873 publications retrieved from the database 318 original research papers met our inclusion criteria (Figure 1.). The analyses of CYP2D6 ( $n=200$ papers) and CYP2C19 ( $n=159$ papers) included 261296 and 257745 healthy individuals. The alleles most frequently investigated were CYP2D6 * $1-{ }^{*} 6,{ }^{*} 10, * 17$ and CYP2C19 * $1-$ *3. Allele frequencies are shown per major geographical region in Table 2 . The most frequently observed variant alleles across all subjects were CYP2D6*2, *4, *10 and $* 41$, and CYP2C19*2 and *17. As expected, allele frequencies varied substantially among ethnicities and countries. We found 89 studies that reported on more than one ethnic group. Overall, African and Middle Eastern countries were underrepresented, while European populations were the most frequently investigated.

Figure 1. Flow diagram of the studies included in the analyses

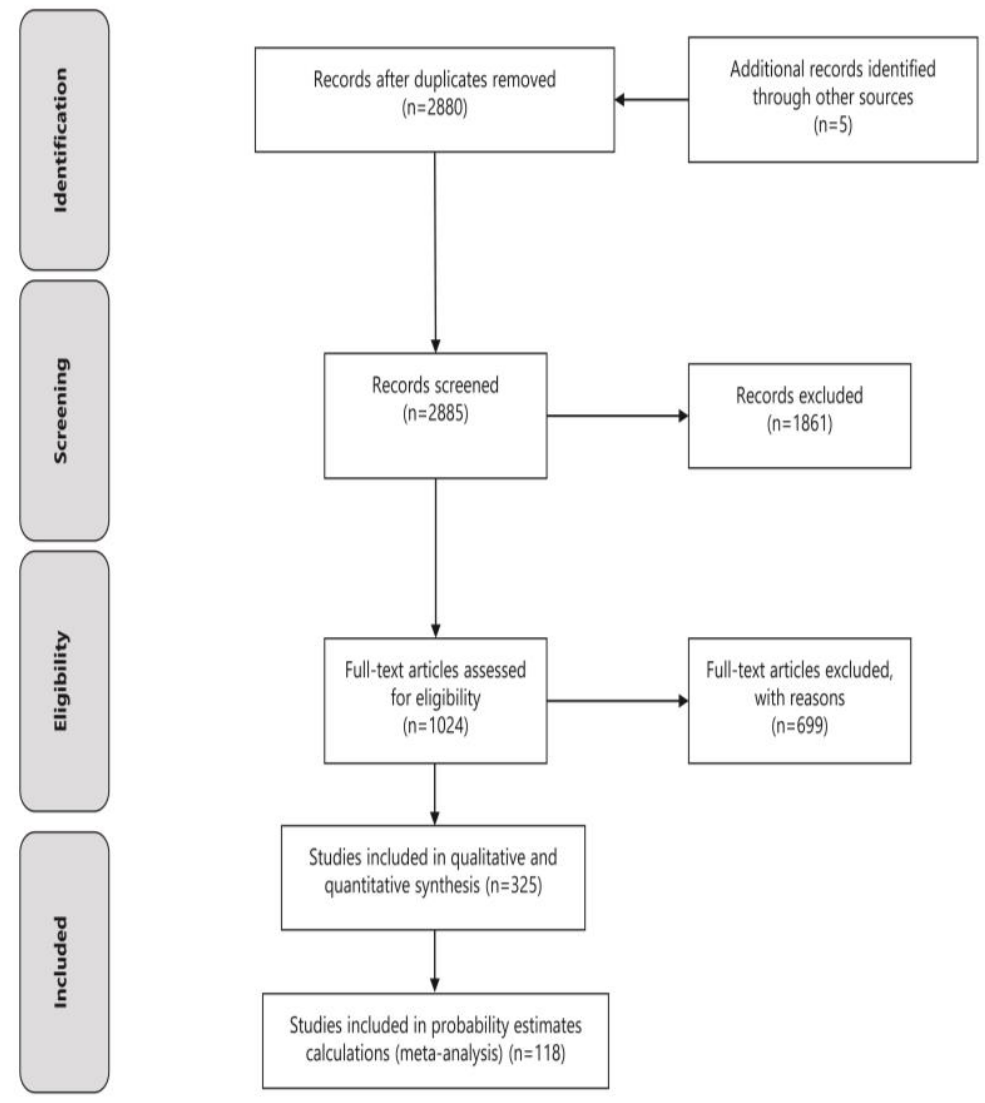




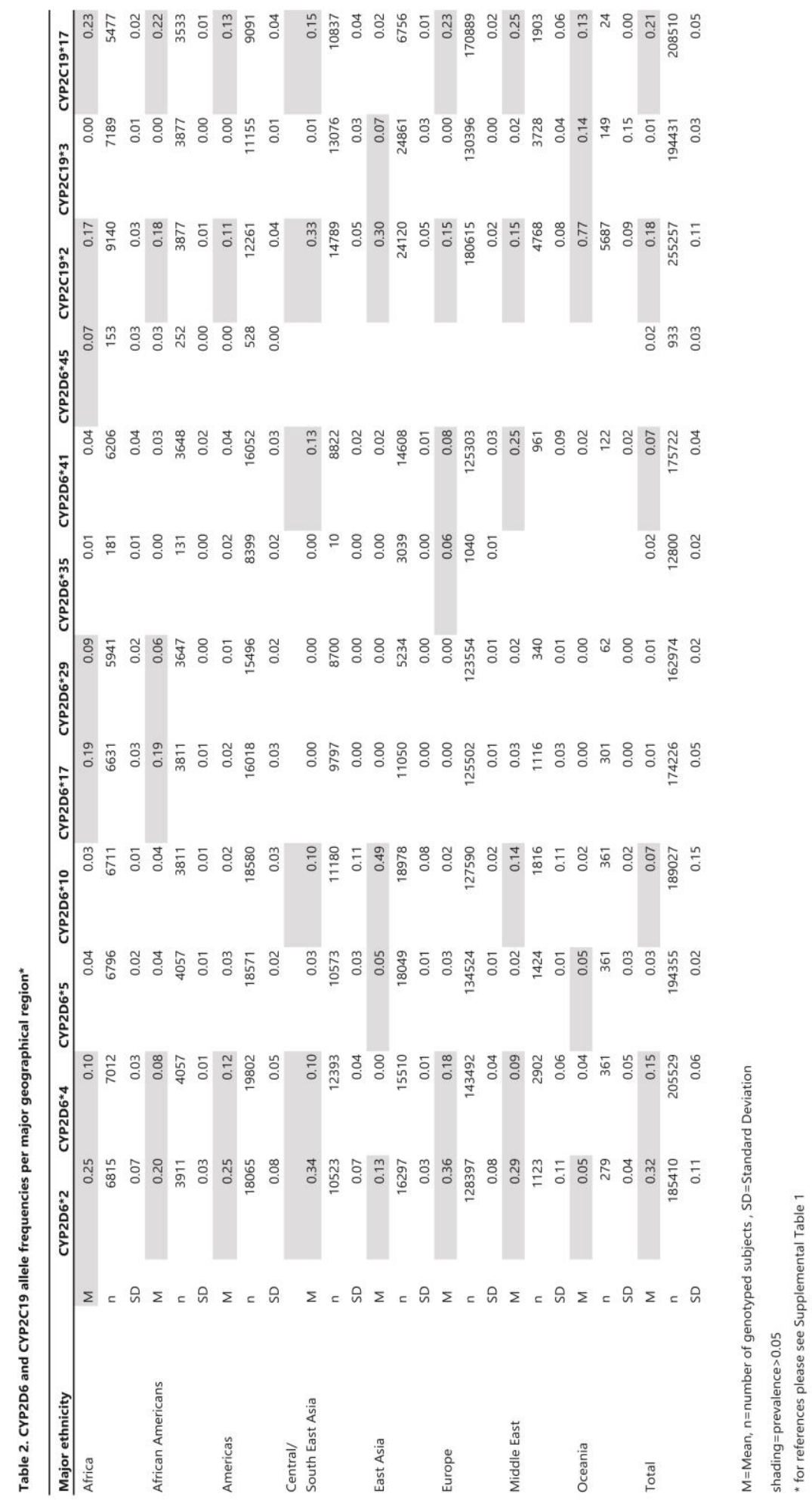




\section{Chapter 2}

\section{CYP2D6}

\section{Prevalence of predicted phenotypes by ethnicity}

Predicted phenotype was reported or could be inferred from 51 studies for 116 ethnicities, covering $n=194714$ individuals. These studies were selected for fulfilling the minimum number of alleles tested as prescribed by our region-specific criteria. Due to the high frequency of allele duplications, high percentages of CYP2D6 UM were found in the Mozabite people, a Berber ethnic group in the Sahara, North Africa (39.5\%)(104); in non-Austronesian Melanesians (21.5\%) (104), and in the ethnoreligious Druze from the Middle East (21.4\%) (104). High percentages of CYP2D6 PM were found in Europeans, for example in the British (12.1\%) (105), the Danish (10.6\%)(106) and Basque (French) people (9.7\%) (104) due to the high frequency of CYP2D6*4. Frequencies of CYP2D6 predicted phenotypes by ethnicity are summarized in Table 3. 


\section{Worldwide variation of CYP2D6 and CYP2C19}

Table 3. Mean frequencies of CYP2D6 predicted phenotypes per ethnicity

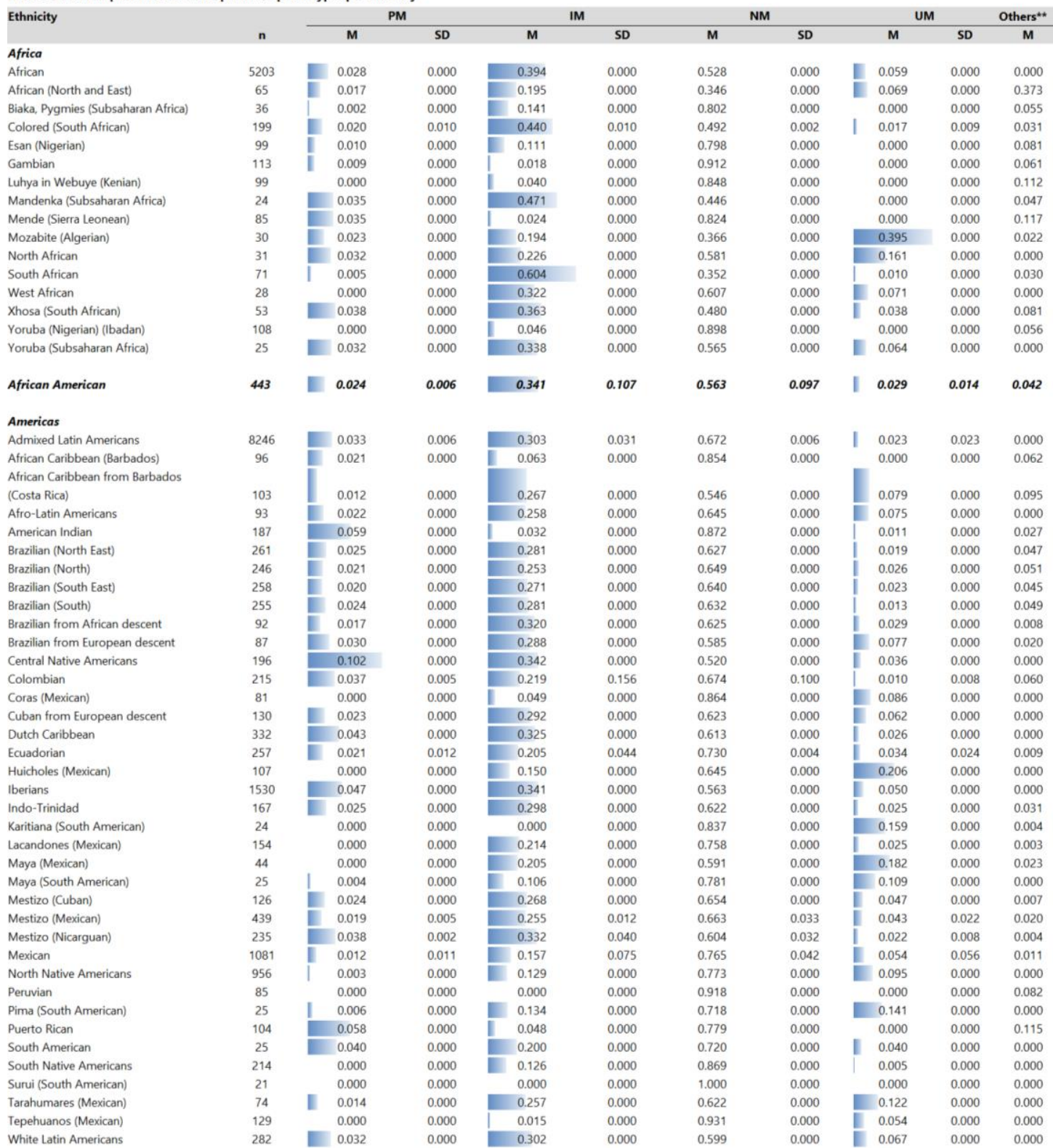




\section{Chapter 2}

\section{Central/South East Asia}

Balochi (Central/South Asia)

Bengali

Brahui (Central/South Asia)

Burusho (Central/South Asia)

Gujarati (Indian)

Hazara (Central/South Asia)

Kalash (Central/South Asia)

Makrani (Central/South Asia)

Pathan (Central/South Asia)

Punjabi (Indian)

Sindhi (Central/South Asia)

South Asian

South East Asia

Tamil (Sri Lankan)

Telugu (Indian)

Uyghurs (Central/South Asia)

Viet Kinh (Vietnamese)

Western India

\section{East Asia}

Chinese

Dai (Chinese)

East Asian

Han (Chinese)

Han (East Asia)

Japanese

Shanghai (Chinese)

Shantou (Chinese)

Shenyang (Chinese)

South Korean

Tibetan Chinese

Xi'an (Chinese)

Yakut (East Asia)

\section{Europe \\ Basque (French) \\ British \\ Danish \\ Estonian \\ European \\ European (USA) \\ Finnish \\ Finnish (East) \\ Finnish (West) \\ French \\ German \\ Hungarian \\ Iberian (Spanish) \\ Jewish (Ashkenazi) \\ Lithuania \\ Ravenna Italian \\ Roma (Italian) \\ Russian \\ Sardinian (Italian) \\ Spanish \\ Toscani (Italian)}

Middle East

Arabian Bedouins (Israel)

Bedouin (Middle Eastern)

Druze (Middle Eastern)

Jewish (Israel)

Palestinian (Westbank)

\section{Oceania}

Aboriginal (North West Australia)

non-Austronesian Melanesian

Total

\begin{tabular}{l|l}
194714 & 0.049
\end{tabular}
0.097

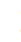

122

$96739-\quad 0.050$

\begin{tabular}{l|l}
305 & 0.060
\end{tabular}

\begin{tabular}{ll}
$956-0.026$ \\
\hline
\end{tabular}

$86 \quad 0.021$

56

$25 \quad 0.048$

$113 \quad 0.070$

\begin{tabular}{l|l}
107 & 0.028
\end{tabular}

$5249 \quad 0.043$

$104 \quad 0.012$

$122-0.040$

$122 \quad 0.066$

\begin{tabular}{l|l}
25 & 0.040
\end{tabular}

0.063

0.051

0.047 \begin{tabular}{l|l}
112 & 0.083
\end{tabular}

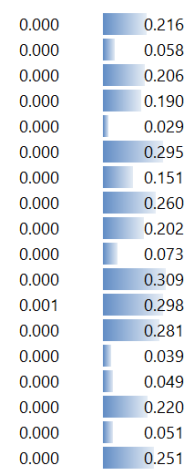

0.000
0.000
0.000
0.000
0.000
0.000
0.000
0.000
0.000
0.000
0.000
0.004
0.000
0.000
0.000
0.000
0.000
0.000

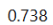

0.884

0.784

0.800

0.951

0.608

0.843

0.720

0.753

0.906

0.666

0.733

0.719

0.882

0.882

0.770

0.949

0.694

\subsection{8}

0.000

0.000

0.007

0.000

0.003

0.000

0.000

0.000

0.004

0.000

0.000

0.000

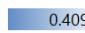

0.012

0.559

0.957

0.451

0.660

0.548

0.732

0.582

0.410

0.584

0.647

0.844

0.544

0.696

0.381

0.221

0.000

\begin{tabular}{l|ll}
0.000 & 0.445 & 0.000 \\
0.000 & 0.121 & 0.000 \\
0.000 & 0.352 & 0.000 \\
0.000 & $\mathbb{1} 0.039$ & 0.000 \\
0.001 & 0.383 & 0.001 \\
0.007 & 0.285 & 0.135 \\
0.008 & $\mathbb{1} 10.030$ & 0.000 \\
0.000 & 0.241 & 0.000 \\
0.000 & 0.220 & 0.000 \\
0.000 & 0.360 & 0.000 \\
0.000 & 0.350 & 0.000 \\
0.000 & 0.365 & 0.000 \\
0.000 & 0.019 & 0.000 \\
0.002 & 0.371 & 0.004 \\
0.000 & 0.207 & 0.000 \\
0.000 & 0.319 & 0.000 \\
0.000 & 0.312 & 0.000 \\
0.000 & 0.302 & 0.000 \\
0.000 & 0.368 & 0.000 \\
0.000 & 0.351 & 0.000 \\
0.000 & $\mathbb{1} 0.065$ & 0.000
\end{tabular}

0.431

0.747

0.525

0.888

0.539

0.599

0.877

0.670

0.672

0.561

0.540

0.508

0.916

0.502

0.781

0.543

0.610

0.557

0.519

0.539

0.869

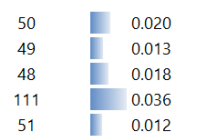

\begin{tabular}{l|ll}
0.000 & 0.220 & 0.000 \\
0.000 & 0.245 & 0.000 \\
0.000 & 0.225 & 0.000 \\
0.042 & 0.442 & 0.055 \\
0.000 & 0.209 & 0.000
\end{tabular}

0.720

0.590

0.536

0.405

0.683

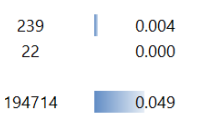

0.000

0.000

$\begin{array}{ll}0.180 & 0.000 \\ 0.002 & 0.000 \\ & \\ 0.287 & 0.149\end{array}$

0.816

0.781

0.644

$0.000+\quad 0.000$

\begin{tabular}{l|l}
0.000 & 0.024
\end{tabular}

\begin{tabular}{l|l}
0.035 & 0.027
\end{tabular}

\begin{tabular}{l|l}
0.152 & 0.019
\end{tabular}

$0.011-0.065$
0.000

$\begin{array}{lll}0.000 & 0.068\end{array}$

$\begin{array}{ll}0.000 & 0.091\end{array}$

$\begin{array}{ll}0.000 & 0.031\end{array}$

$0.000 \quad 0.040$

$0.000 \quad \square \quad 0.019$

0.000

0.003

0.000

0.000

0.000

0.000

0.000
0.000

0.000

0.000

0.087

0.000

0.006
0.008

0.061

0.026

1. 0.053

0.000

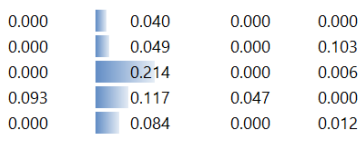

n=number of genotyped subjects, SD=Standard Deviation,

PM=Poor Metabolizers, IM=Intermediate Metabolizers, NM= Normal Metabolizers, UM= Ultrarapid Metabolizers

${ }^{*}$ for references please see Supplemental Table 2

** a SNP combination that could not be assigned to a known allele/phenotype 


\section{Probability estimates by country}

The probability of having a CYP2D6 non-NM predicted phenotype is the highest in Algeria (non-NM probability estimated to be $61.2 \%)(* 4, * 17, * 41$ and duplications)(104), Argentina (non-NM probability estimate $51.4 \%)(* 4, * 41$ and duplications)(10), and France (non-NM probability estimate 50.4\%) ( $* 4, * 5, * 41$ and duplications)(104). The CYP2D6 non-NM probability estimate was lowest in several populations from Africa (Gambia 2.7\%, Kenya 4.0\% and Sierra Leone 5.9\%) and South-East Asia (Vietnam 5.1\%, Sri Lanka 7.8\%) (105). See Figure 2 for CYP2D6 nonNM probability estimates and Figure 3 for CYP2D6 non-NM probability estimates plotted on a world map.

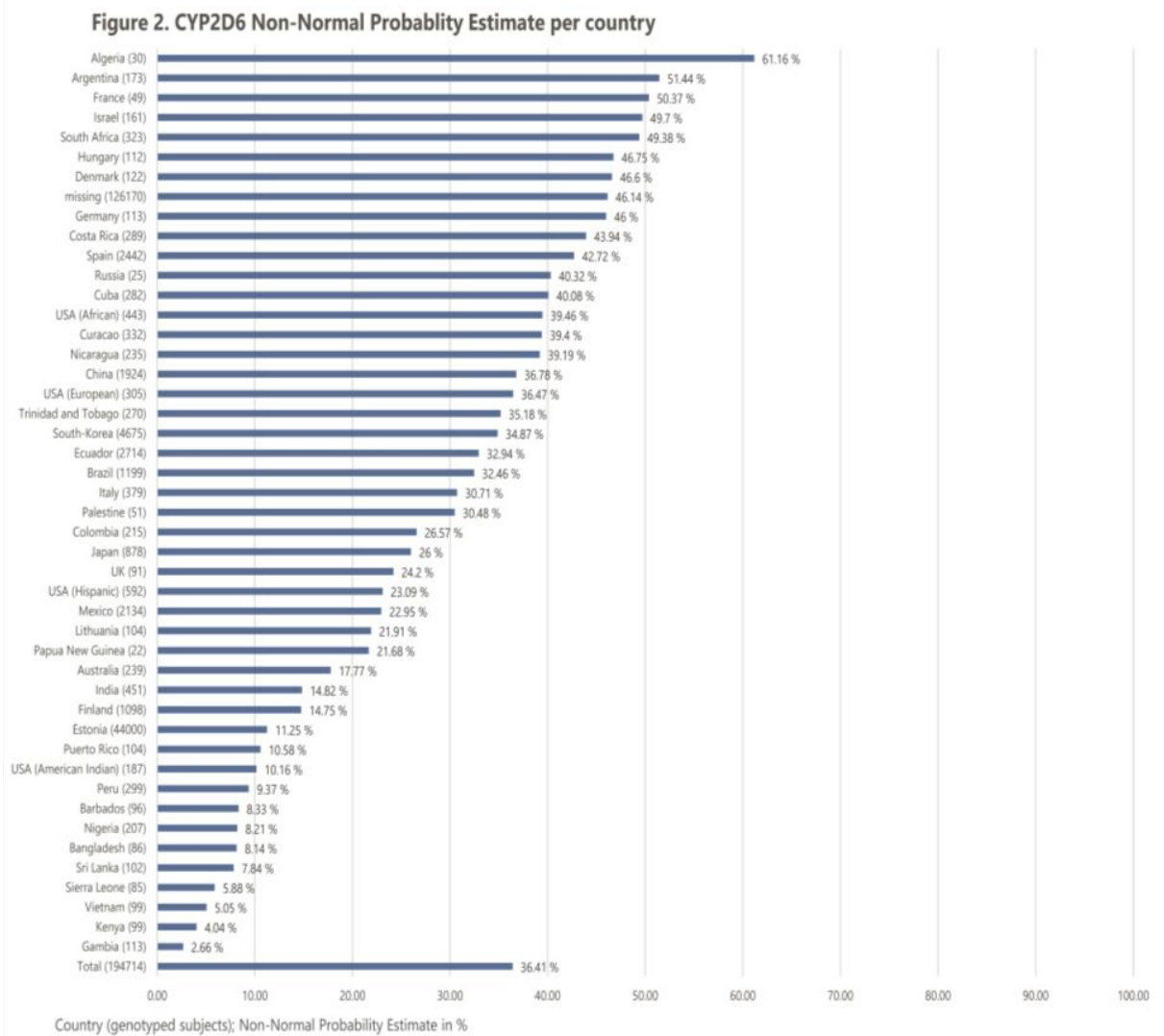


Chapter 2

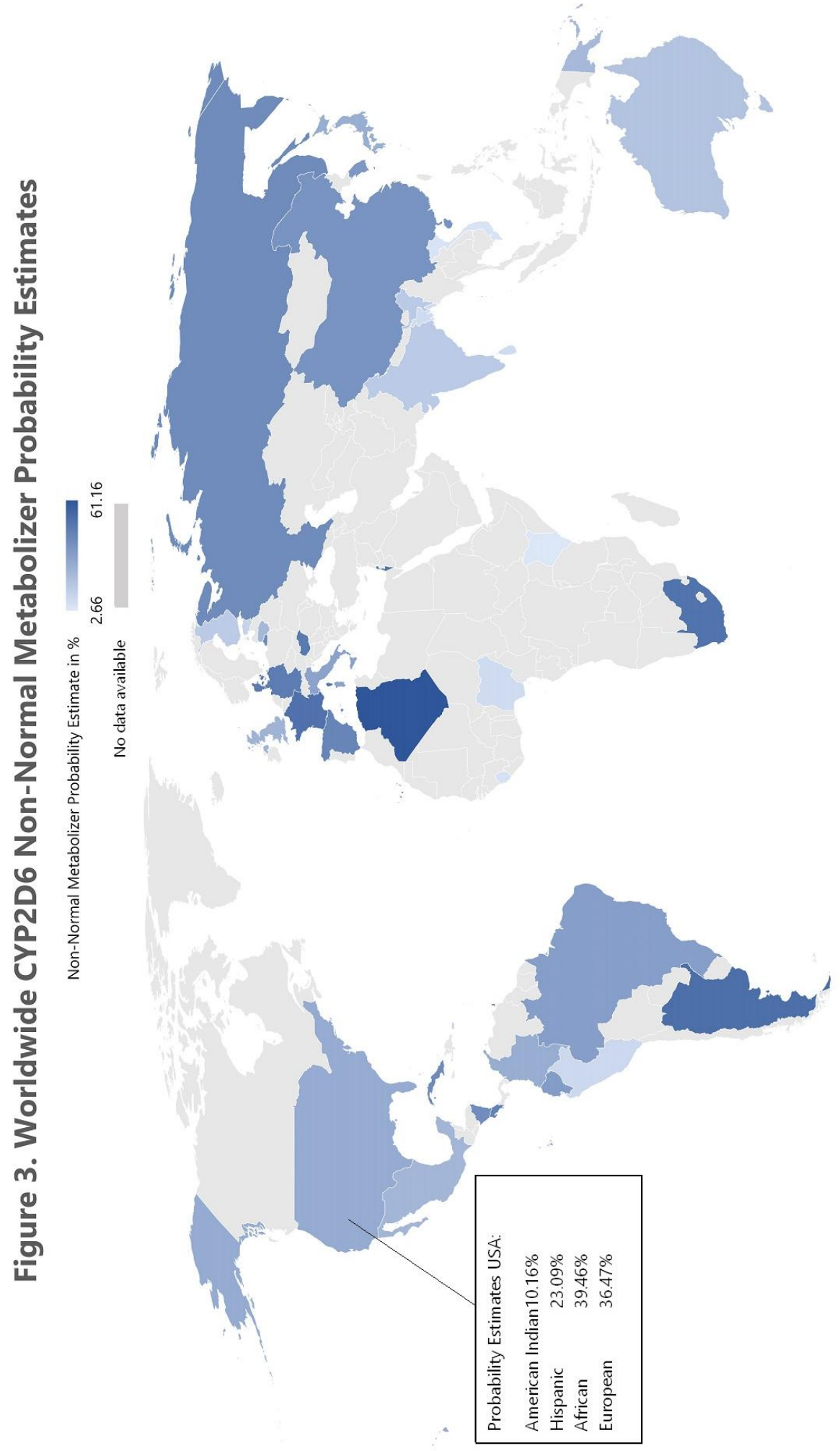


CYP2C19

Prevalence of predicted phenotypes by ethnicity

Data were retrieved from 73 studies describing 225173 subjects of 85 ethnic groups/countries. These studies were selected for fulfilling the minimum number of alleles tested as prescribed by our region-specific criteria. The UM predicted phenotype is rather common in Ecuadorian Mestizos (41.4\%) (107), Dargins (39.8\%) (108), and ethnic groups living in the North Caucasus in Russia, and in Burushu, Pakistan $(39.0 \%)(109,110)$ owing to a high prevalence of over $20 \%$ of CYP2C19*17 in all these populations. High percentages of CYP2C19 PMs were found in Indian and Pakistani populations (Naik 31.0\% (111) and Saraiki 20.0\% (110)), Tohoku Japanese (18.9\%) (112), and in Chinese Hui $(28.0 \%)(113,114)$ due to the presence of the CYP2C19*2 and *3 non-functional alleles. Table 4 summarizes the frequencies of CYP2C19 predicted phenotypes by ethnicity. 


\section{Chapter 2}

Table 4. Mean frequencies of CYP2C19 predicted phenotypes per ethnicity*

\begin{tabular}{|c|c|c|c|c|c|c|c|c|c|c|}
\hline \multirow[t]{2}{*}{ Ethnicity } & \multirow[b]{2}{*}{$\mathbf{n}$} & \multicolumn{2}{|c|}{ PM } & \multicolumn{2}{|c|}{ IM } & \multicolumn{2}{|c|}{ NM } & \multicolumn{2}{|c|}{ UM } & \multirow{2}{*}{$\begin{array}{c}\text { Others }^{* *} \\
\text { M }\end{array}$} \\
\hline & & $M$ & SD & M & SD & M & SD & M & SD & \\
\hline \multicolumn{11}{|l|}{ Africa } \\
\hline African & 5203 & 0.033 & 0.000 & 0.310 & 0.000 & 0.344 & 0.000 & 0.335 & 0.000 & 0.000 \\
\hline \multicolumn{11}{|l|}{ Cape Mixed Ancestry } \\
\hline (South African) & 75 & 0.080 & 0.000 & 0.400 & 0.000 & 0.350 & 0.000 & 0.170 & 0.000 & 0.000 \\
\hline Tzotziles (Ugandese) & 99 & 0.020 & 0.000 & 0.230 & 0.000 & 0.510 & 0.000 & 0.240 & 0.000 & 0.000 \\
\hline Xhosa (South African) & 100 & 0.030 & 0.000 & 0.490 & 0.000 & 0.390 & 0.000 & 0.090 & 0.000 & 0.000 \\
\hline African American & 3533 & 0.039 & 0.007 & 0.308 & 0.001 & 0.337 & 0.013 & 0.316 & 0.020 & 0.001 \\
\hline
\end{tabular}

\section{Americas}

\begin{tabular}{|c|c|c|c|c|c|c|c|c|c|c|}
\hline Admixed Latin Americans & 5789 & 0.011 & 0.000 & 0.192 & 0.000 & 0.661 & 0.000 & 0.210 & 0.000 & 0.000 \\
\hline \multicolumn{11}{|l|}{ African Caribbeans from } \\
\hline Barbados (Costa Rica) & 46 & 0.000 & 0.000 & 0.315 & 0.000 & 0.345 & 0.000 & 0.326 & 0.000 & 0.014 \\
\hline Brazilian & 1043 & 0.018 & 0.000 & 0.230 & 0.000 & 0.482 & 0.000 & 0.270 & 0.000 & 0.000 \\
\hline Bribri (Costa Rican) & 23 & 0.000 & 0.000 & 0.082 & 0.000 & 0.834 & 0.000 & 0.087 & 0.000 & 0.000 \\
\hline Costa Rican & 36 & 0.000 & 0.000 & 0.219 & 0.000 & 0.717 & 0.000 & 0.056 & 0.000 & 0.008 \\
\hline Dutch Caribbean & 332 & 0.041 & 0.000 & 0.241 & 0.000 & 0.372 & 0.000 & 0.345 & 0.000 & 0.001 \\
\hline Ecuadorian & 139 & 0.008 & 0.000 & 0.243 & 0.000 & 0.591 & 0.000 & 0.159 & 0.000 & 0.000 \\
\hline Guarani (Brazil) & 90 & 0.012 & 0.000 & 0.197 & 0.000 & 0.771 & 0.000 & 0.019 & 0.000 & 0.000 \\
\hline Guaymi (Costa Rican) & 24 & 0.000 & 0.000 & 0.000 & 0.000 & 0.960 & 0.000 & 0.040 & 0.000 & 0.000 \\
\hline Mestizo (Costa Rican) & 141 & 0.000 & 0.000 & 0.144 & 0.000 & 0.671 & 0.000 & 0.177 & 0.000 & 0.008 \\
\hline Mestizo (Ecuadorian) & 297 & 0.007 & 0.000 & 0.151 & 0.000 & 0.428 & 0.000 & 0.414 & 0.000 & 0.000 \\
\hline Mestizo (Mexican) & 300 & 0.000 & 0.000 & 0.170 & 0.000 & 0.660 & 0.000 & 0.170 & 0.000 & 0.000 \\
\hline Mexican & 568 & 0.014 & 0.007 & 0.208 & 0.007 & 0.696 & 0.070 & 0.082 & 0.084 & 0.000 \\
\hline
\end{tabular}

Central/ South East Asia

Buruhi (Pakistani)

Burushu (Pakistani)

Hazara (Pakistani)

Indian (West)

Kalash (Pakistani)

Koya (Indian)

Naik (Indian)

Pakistani

Parsi (Pakistani)

Pathan (Pakistani)

Punjabi (Pakistani)

Saraiki (Pakistani)

Sindhi (Pakistani)

South Asian

Tamil (Indian) (South)

\begin{tabular}{c|c|c|}
\hline 118 & 0.060 \\
28 & 0.000 \\
102 & 0.000 \\
102 & 0.123 \\
64 & 0.050 \\
460 & 0.152 \\
100 & 0.310 \\
685 & 0.121 \\
90 & 0.000 \\
170 & 0.070 \\
218 & 0.070 \\
59 & 0.200 \\
179 & 0.089 \\
8256 & 0.118 \\
206 & 0.184 \\
\hline
\end{tabular}

\begin{tabular}{l|l|l}
0.000 & 0.600 & 0.000 \\
\hline 0.000 & 0.150 & 0.000 \\
0.000 & 0.410 & 0.000 \\
0.000 & 0.455 & 0.000 \\
0.000 & 0.560 & 0.000 \\
0.000 & 0.499 & 0.000 \\
0.000 & 0.450 & 0.000 \\
0.013 & 0.452 & 0.014 \\
0.000 & 0.320 & 0.000 \\
0.000 & 0.460 & 0.000 \\
0.000 & 0.460 & 0.000 \\
0.000 & 0.400 & 0.000 \\
0.000 & 0.453 & 0.000 \\
0.000 & 0.458 & 0.000 \\
0.000 & 0.310 & 0.000
\end{tabular}

0.200
0.460
0.270
0.299
0.280
0.150
0.130
0.184
0.300
0.320
0.280
0.300
0.352
0.280
0.288

\begin{tabular}{l|l|}
\hline 0.000 & 0.140 \\
\hline 0.000 & 0.390 \\
0.000 & 0.320 \\
0.000 & 0.123 \\
0.000 & 0.110 \\
0.000 & 0.197 \\
0.000 & 0.110 \\
0.047 & 0.243 \\
0.000 & 0.380 \\
0.000 & 0.150 \\
0.000 & 0.190 \\
0.000 & 0.100 \\
0.000 & 0.106 \\
0.000 & 0.162 \\
0.000 & 0.219 \\
\hline
\end{tabular}

$\begin{array}{ll}0.000 & 0.000 \\ 0.000 & 0.000 \\ 0.000 & 0.000 \\ 0.000 & 0.000 \\ 0.000 & 0.000 \\ 0.000 & 0.003 \\ 0.000 & 0.000 \\ 0.020 & 0.000 \\ 0.000 & 0.000 \\ 0.000 & 0.000 \\ 0.000 & 0.000 \\ 0.000 & 0.000 \\ 0.000 & 0.000 \\ 0.000 & 0.000 \\ 0.000 & 0.000\end{array}$

\section{East Asia}

Bai (Chinese)

Chinese

East Asian

Hakka (Chinese)

Han (Chinese)

Han (Chinese) (North)

\begin{tabular}{c|c|}
\hline 202 & 0.095 \\
754 & 0.127 \\
5407 & 0.142 \\
6686 & 0.131 \\
1972 & 0.144 \\
1000 & 0.137 \\
1127 & 0.146 \\
180 & 0.118 \\
\hline 265 & 0.280 \\
\hline 2577 & 0.175 \\
107 & 0.075 \\
265 & 0.117 \\
553 & 0.123 \\
96 & 0.135 \\
96 & 0.073 \\
96 & 0.042 \\
1962 & 0.131 \\
96 & 0.041 \\
\hline 57 & 0.189 \\
\hline 459 & 0.095 \\
96 & 0.146 \\
\hline
\end{tabular}

\begin{tabular}{l|ll}
0.000 & 0.425 & 0.000 \\
0.025 & 0.463 & 0.008 \\
0.013 & 0.463 & 0.019 \\
0.000 & 0.452 & 0.000 \\
0.043 & 0.437 & 0.038 \\
0.000 & 0.488 & 0.000 \\
0.000 & 0.502 & 0.000 \\
0.000 & 0.516 & 0.000 \\
0.023 & 0.441 & 0.070 \\
0.038 & 0.488 & 0.038 \\
0.000 & 0.318 & 0.000 \\
0.039 & 0.439 & 0.043 \\
0.056 & 0.427 & 0.047 \\
0.000 & 0.385 & 0.000 \\
0.000 & 0.365 & 0.000 \\
0.000 & 0.327 & 0.000 \\
0.020 & 0.474 & 0.030 \\
0.000 & 0.406 & 0.000 \\
0.000 & 0.575 & 0.000 \\
0.035 & 0.382 & 0.070 \\
0.000 & 0.313 & 0.000
\end{tabular}

0.473
0.410
0.380
0.417
0.416
0.373
0.349
0.365
0.279
0.333
0.607
0.443
0.450
0.469
0.510
0.598
0.391
0.563
0.213
0.530
0.521

\begin{tabular}{l|l}
0.000 & 0.000 \\
0.016 & 0.001 \\
0.013 & 0.021 \\
0.000 & 0.000 \\
0.064 & 0.002 \\
0.000 & 0.000 \\
0.000 & 0.000 \\
0.000 & 0.000 \\
0.093 & 0.000 \\
0.040 & 0.003 \\
0.000 & 0.000 \\
0.081 & 0.000 \\
0.099 & 0.000 \\
0.000 & 0.000 \\
0.000 & 0.021 \\
0.000 & 0.033 \\
0.030 & 0.003 \\
0.000 & $\mid$
\end{tabular}

$\begin{array}{ll}0.000 & 0.006 \\ 0.003 & 0.000 \\ 0.011 & 0.000 \\ 0.000 & 0.000 \\ 0.009 & 0.002 \\ 0.000 & 0.002 \\ 0.000 & 0.003 \\ 0.000 & 0.001 \\ 0.000 & 0.000 \\ 0.005 & 0.001 \\ 0.000 & 0.000 \\ 0.000 & 0.000 \\ 0.000 & 0.000 \\ 0.000 & 0.011 \\ 0.000 & 0.031 \\ 0.000 & 0.000 \\ 0.007 & 0.000 \\ 0.000 & 0.000 \\ 0.000 & 0.023 \\ 0.000 & 0.000 \\ 0.000 & 0.010\end{array}$




\begin{tabular}{|c|c|c|c|c|c|c|c|c|c|c|}
\hline \multicolumn{11}{|l|}{ Europe } \\
\hline Avars (Russian) & 90 & | 0.016 & 0.000 & 0.222 & 0.000 & 0.453 & 0.000 & 0.309 & 0.000 & 0.000 \\
\hline Danish & 276 & 0.022 & 0.000 & 0.258 & 0.000 & 0.442 & 0.000 & 0.279 & 0.000 & 0.000 \\
\hline Dargins (Russian) & 50 & 0.003 & 0.000 & 0.095 & 0.000 & 0.504 & 0.000 & 0.398 & 0.000 & 0.000 \\
\hline Estonian & 44000 & 0.024 & 0.000 & 0.236 & 0.000 & 0.359 & 0.000 & 0.381 & 0.000 & 0.000 \\
\hline European & 96882 & 0.027 & 0.005 & 0.274 & 0.020 & 0.374 & 0.012 & 0.329 & 0.008 & 0.000 \\
\hline European (USA) & 17810 & | 0.023 & 0.002 & 0.255 & 0.005 & 0.410 & 0.010 & 0.311 & 0.007 & 0.000 \\
\hline Faroese & 311 & 0.032 & 0.000 & 0.309 & 0.000 & 0.460 & 0.000 & 0.199 & 0.000 & 0.000 \\
\hline Finnish (North) & 497 & 0.003 & 0.000 & 0.111 & 0.000 & 0.585 & 0.000 & 0.300 & 0.000 & 0.000 \\
\hline Greek & 283 & || 0.021 & 0.000 & 0.219 & 0.000 & 0.442 & 0.000 & 0.318 & 0.000 & 0.000 \\
\hline Hispanic (USA) & 3509 & 0.021 & 0.000 & 0.226 & 0.006 & 0.531 & 0.007 & 0.223 & 0.001 & 0.000 \\
\hline Jewish & 250 & 0.044 & 0.000 & 0.252 & 0.000 & 0.416 & 0.000 & 0.288 & 0.000 & 0.000 \\
\hline Jewish (Ashkenazi) & 5326 & | 0.023 & 0.001 & 0.253 & 0.010 & 0.457 & 0.013 & 0.264 & 0.005 & 0.004 \\
\hline Jewish (Sephardi) & 135 & 0.012 & 0.000 & 0.160 & 0.000 & 0.522 & 0.000 & 0.267 & 0.000 & 0.039 \\
\hline Laks (Russian) & 46 & 0.034 & 0.000 & 0.300 & 0.000 & 0.372 & 0.000 & 0.294 & 0.000 & 0.000 \\
\hline Macedonian & 184 & \ 0.027 & 0.000 & 0.234 & 0.000 & 0.418 & 0.000 & 0.321 & 0.000 & 0.000 \\
\hline Nanai (Russian) & 70 & 0.108 & 0.000 & 0.442 & 0.000 & 0.423 & 0.000 & 0.028 & 0.000 & 0.000 \\
\hline Norwegian & 309 & 0.013 & 0.000 & 0.279 & 0.000 & 0.395 & 0.000 & 0.314 & 0.000 & 0.000 \\
\hline Scandinavian & 394 & 0.020 & 0.000 & 0.242 & 0.000 & 0.450 & 0.000 & 0.288 & 0.000 & 0.000 \\
\hline Spanish (North) & 282 & 0.018 & 0.000 & 0.213 & 0.000 & 0.500 & 0.000 & 0.269 & 0.000 & 0.000 \\
\hline Swedish & 185 & 0.026 & 0.000 & 0.269 & 0.000 & 0.410 & 0.000 & 0.296 & 0.000 & 0.000 \\
\hline \multicolumn{11}{|l|}{ Middle East } \\
\hline Caspian (Iranian) & 73 & 0.012 & 0.000 & 0.194 & 0.000 & 0.518 & 0.000 & 0.275 & 0.000 & 0.000 \\
\hline Fars (Iranian) & 180 & 0.033 & 0.000 & 0.298 & 0.000 & 0.287 & 0.000 & 0.382 & 0.000 & 0.000 \\
\hline Iranian & 232 & 0.030 & 0.015 & 0.224 & 0.014 & 0.414 & 0.005 & 0.331 & 0.023 & 0.002 \\
\hline Kurd (Iranian) & 95 & 0.077 & 0.000 & 0.401 & 0.000 & 0.259 & 0.000 & 0.264 & 0.000 & 0.000 \\
\hline Lure (Iranian) & 80 & 0.127 & 0.000 & 0.459 & 0.000 & 0.033 & 0.000 & 0.381 & 0.000 & 0.000 \\
\hline Saudi Arabian & 393 & 0.005 & 0.001 & 0.150 & 0.001 & 0.603 & 0.178 & 0.242 & 0.176 & 0.001 \\
\hline Turk (Iranian) & 110 & 0.072 & 0.000 & 0.392 & 0.000 & 0.214 & 0.000 & 0.321 & 0.000 & 0.000 \\
\hline Turkish & 369 & I 0.027 & 0.031 & 0.163 & 0.186 & 0.485 & 0.206 & 0.325 & 0.011 & 0.000 \\
\hline \multicolumn{11}{|l|}{ Oceania } \\
\hline Pacific Islander & 24 & 0.000 & 0.000 & 0.167 & 0.000 & 0.583 & 0.000 & 0.250 & 0.000 & 0.000 \\
\hline Total & 225173 & 0.042 & 0.041 & 0.290 & 0.079 & 0.386 & 0.071 & 0.287 & 0.111 & 0.000 \\
\hline
\end{tabular}

$\mathrm{n}=$ number of genotyped subjects, $\mathrm{SD}=$ Standard Deviation,

PM=Poor Metabolizers, IM=Intermediate Metabolizers, $\mathrm{NM}=$ Normal Metabolizers, $\mathrm{UM}=$ Ultrarapid Metabolizers

* for references please see Supplemental Table 3

** a SNP combination that could not be assigned to a known allele/phenotype 


\section{Chapter 2}

\section{Probability estimates by country}

The probability of having a CYP2C19 non-NM predicted phenotype due to high frequencies of the non-functional CYP2C19*2 allele and/or the increased function CYP2C19*17 allele is highest in India (non-NM probability estimate $80.1 \%$ ) $(111,115,116)$, Pakistan (non-NM probability estimate $74.8 \%)(110,117,118)$, and Iran (non-NM probability estimate $69.2 \%)(119,120)$. The probability is lowest in countries in the Americas, particularly Mexico (non-NM probability estimate 31.7\%) (121-123) and Costa Rica (non-NM probability estimate 33.9\%) (124). CYP2C19 non-NM probability estimates are shown in Figure 4 and Figure 5 displays CYP2C19 non-NM probability estimates on a world map.

Figure 4. CYP2C19 Non-Normal Probability Estimate per country

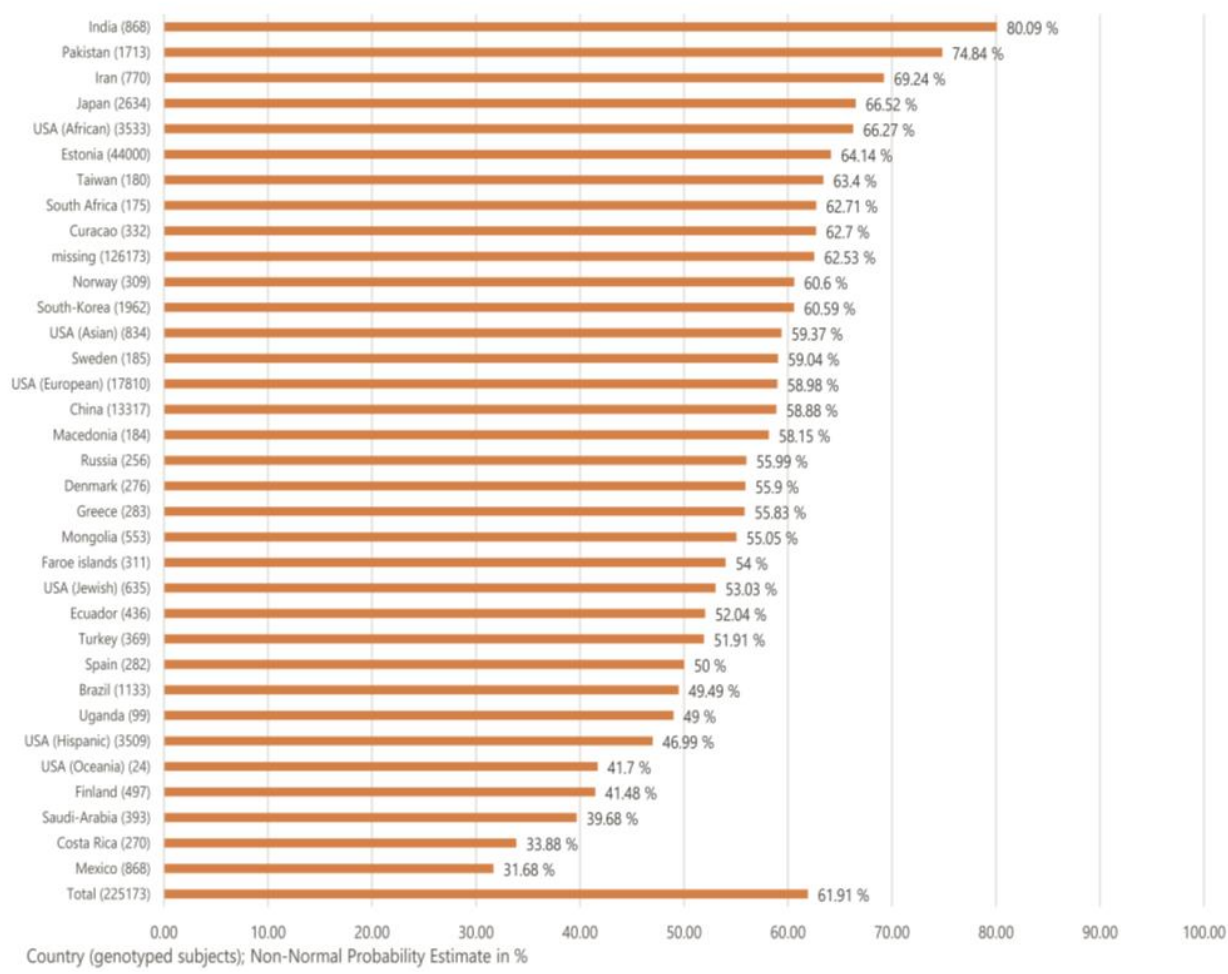


Worldwide variation of CYP2D6 and CYP2C19
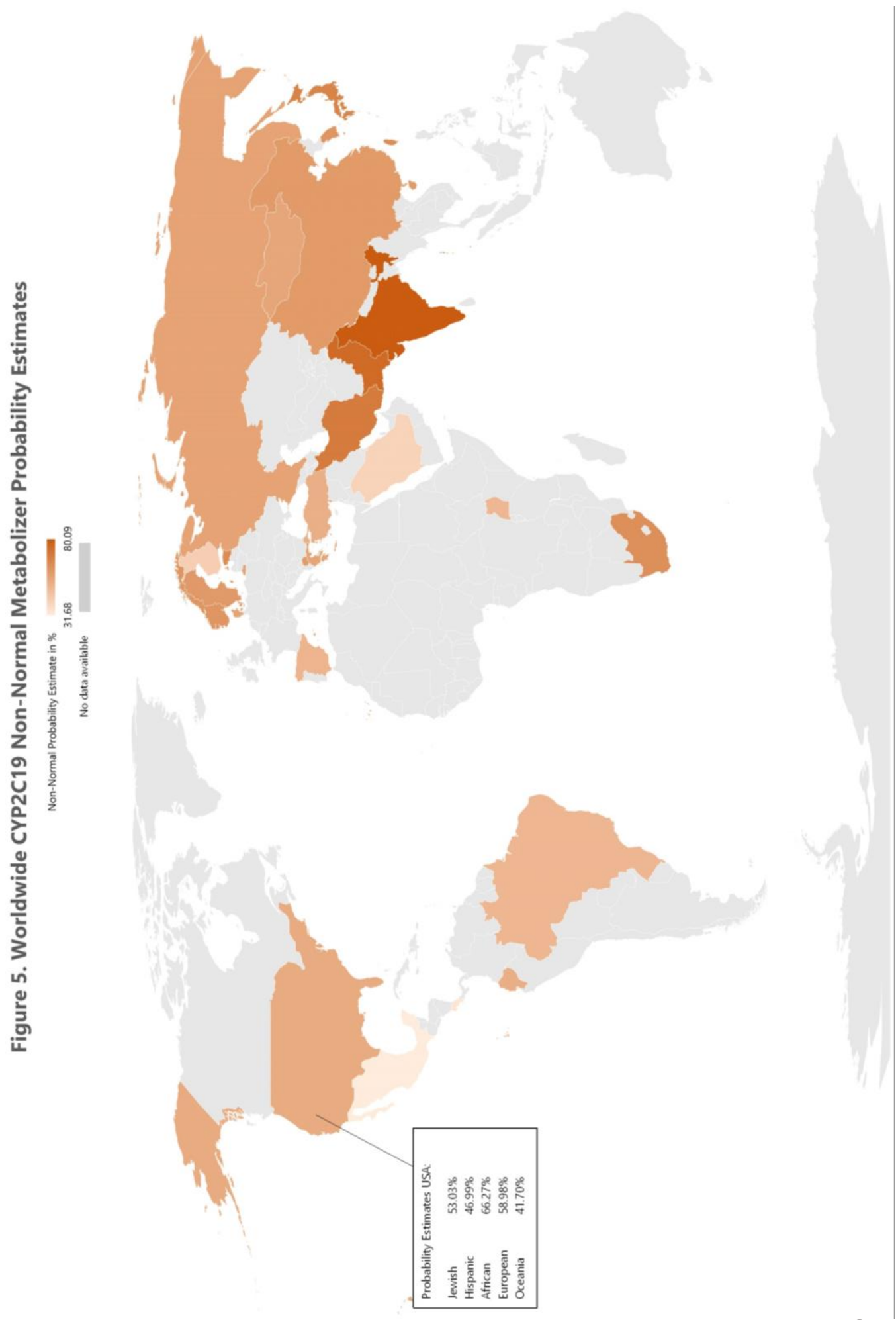


\section{Chapter 2}

\section{Discussion}

In this meta-analysis we introduce a clinical useful concept of a non-normal metabolizer (non-NM) probability estimate as the equivalent of the sum-prevalence (in percentages) of PM + IM + UM predicted CYP2D6 and CYP2C19 phenotypes. The mean totals of non-NM probability estimates worldwide were $36.4 \%$ (CYP2D6) and $61.9 \%$ (CYP2C19). This means that more than half of all psychiatric patients have a non-normal predicted CYP2D6 and/or CYP2C19 metabolizer phenotype. Since $>75 \%$ of the psychopharmacological drugs are metabolized by one or both of these enzymes $(29,125)$, the results of our meta-analysis emphasize the importance of integrating pharmacogenetic information into clinical practice, especially when treating patients who have had adverse drug events or shown treatment resistance.

We included a total of 318 studies in our meta-analysis of CYP2D6 and CYP2C 19 genotypes in healthy populations of which genotype requirements were fulfilled by 118 studies (37\%). This is an important requirement, because having too few CYP2D6 or CYP2C19 alleles in a study may not accurately determine predicted phenotype from genotype data.

\section{Diversity within major ethnicities}

Although grouping populations can simplify reporting of pharmacogenetic alleles, we grouped ethnicities within geographical regions to enable comparisons with other published meta-analyses $(126,127)$. The prevalences of our CYP2D6 predicted phenotypes were in general agreement with those reported by Gaedigk et al(11). However, our data predicted a higher percentage of UMs for Africans (i.e. 5.5\%, $n=562$ versus $3.8 \%, n=430$ ). This difference may be explained by the fact that we weighted the number of genotyped subjects when calculating the mean allele frequencies for our meta-analysis. In Gaedigk et al's report, studies were not weighted by sample size, so small studies might have had a bigger influence on the mean. We also included two studies in Africans that were not included by Gaedigk et al due to their small sample size and thus not meeting their requirements of at least 50 study subjects; they both reported higher frequencies of UMs $(104,128)$. In contrast, in the South Central Asian population the percentage of UMs found by Gaedigk et al was higher than those reported here, $2.8 \%(n=370)$ vs. $2.1 \%(n=434)$, due to the inclusion of two studies in South East Asians in this meta-analysis, which found no ultrarapid metabolizers $(128,129)$

In contrast with Fricke-Galindo et al (82) and the CPIC's CYP2C19 allele frequency table (https://www.pharmgkb.org/page/cyp2c19RefMaterials), we found a much higher prevalence of $25.0 \%$ for CYP2C19 UMs in Oceania (vs. $0 \%$ and $1.5 \%$ ). This is because we only included studies investigating the CYP2C 19*17 increased function 
allele, which leads to rapid and ultrarapid metabolizer predicted phenotypes. Studies that do not investigate this allele yield underestimates of the prevalence of UMs.

\section{Clinical practice}

Some issues need to be addressed in translating genotype data to information useful for clinical practice. Although prevalences of non-NM are high, there is no conclusive evidence whether CYP genotyping is beneficial for clinical outcomes in psychiatric practice. There are a few prospective studies analyzing the clinical utility of CYP genotyping and they report contradictory outcomes in diverse populations $(7,87,88)$. So far, it is still unclear which patient groups might benefit from genotyping and see better treatment outcomes. One reason for the uncertainty is the possibility of the transformation of genotypic EMs into phenotypic PMs by multiple causes, for example, due to smoking, CYP2D6 and CYP2C19 inhibiting medication (e.g. bupropion and esomeprazole), CYP2D6 and CYP2C19 inducing medication (e.g. oritavancin and carbamazepine), and inflammation or co-morbidities $(16,130)$. This phenomenon is called phenoconversion: it has been described in diverse populations $(17,18,131)$. If this is happening on a large scale, it means genotypic outcomes could be unreliable for use in clinical practice. It may already influence outcomes of studies on the effectivity of CYP genotyping in clinical practice (88). Another issue may arise with genotyping patients who have been on treatment for several years, because their brain has adapted to the changed levels of neurotransmitters and the sideeffects are no longer reversible $(132,133)$.

Lastly, the category of the intermediate metabolizer has been the subject of debate(134). In this meta-analysis we categorized the IM as defined by the CPIC (33). Because IMs only show minor differences in metabolism from EMs (135), one could categorize them in the NM group. However, other studies have indicated that IMs show lower oral drug clearance, higher blood serum levels, and have higher chances of side-effects than EMs (136-138). For this reason, we consider the IM status is clinically relevant for psychiatric patients and guidelines for some medications are now advising dose adjustments for this predicted phenotype $(44,139)$. Estimations of the worldwide prevalence of only PM+UM were $7.75 \%$ (CYP2D6) and $32.94 \%$ (CYP2C19) (Supplemental Figures 1+2).

\section{Strengths and limitations}

We included studies with a small number of participants $(n \geq 20)$, as well as controls from case-control studies, which increased the number of studies we could include. Bias was minimized by excluding studies of populations diagnosed with a disease to 


\section{Chapter 2}

prevent confounding our data (i.e. disease-associations with specific allele frequencies (140-146)). On the other hand, some large studies had to be excluded due to their inclusion of non-healthy individuals which might have biased the outcomes of some countries (147).

Another strength is that we used region-specific inclusion criteria to maximize the accuracy of the phenotype predictions $(11,82,86)$. This helped to avoid applying criteria based on studies in Western countries to other regions of the world. This led to the exclusion of studies reporting on too few allelic variants, and of studies focusing on the determination of only poor or ultrarapid metabolizers in a population $(81,148,149)$.

Studies reporting allele frequencies of merely CYP2C19*2 and *3 or studies investigating CYP2D6 allele duplications, but with no minimum set of variants, are certainly of scientific importance, but not of practical importance for clinicians because no complete risk inventory of the metabolizer phenotype could be determined. Because we excluded studies not investigating CYP2C19*17, we had only one report describing Oceanians $(n=24)(150)$, which did not identify any PMs.

A limitation is that we were depended on the sensitivity of the tests of the individual studies. For example, because of overlap in SNPs in the CYP2D6*10 and *36 and in the CYP2D6*17 and *40 allele, a slight over- or underestimation of some predicted phenotypes might have been reported in some studies (151).

The inclusion of studies with a small number of participants (20-50) could have led to an over- or underestimation of predicted phenotypes in some populations, but the influence on the mean prevalence was minimized by weighting the number of genotyped subjects. We may still have made over- or underestimates where there are few studies for a certain region/country along with a relatively small number of studied subjects. Because few studies reporting specific minority ethnicities met our inclusion criteria, we did not want to exclude potentially valuable information from our meta-analysis by setting too-stringent participant number requirements.

Although we only included studies on homogenous ethnic groups in this metaanalysis, we are aware of the limitations of grouping ethnicities based on selfreported ethnicity. Although ancestry based on genetic information is more objective than self-reported ethnicity, much of the research into CYP genotypes has been based on self-reported ethnicity, while for a few minority populations, some genetic data were systematically analyzed. In a study of 103,006 participants with 23 ethnicities, a very high correspondence was found between self-reported ethnicity and genetic ancestry (152). Only African-Americans and Latino-Americans demonstrated a higher degree of ancestral admixture than self-reported. 
Second, although studies of genetic ancestry show there is a strong linkage between belonging to an ethnic group and coming from a certain geographical region, ethnicity is not always the same as geographical region (101). Ethnic groups migrate and although some ethnicities show almost no admixture with the local ethnicity even many years after migration, other ethnicities do show a mixture of multiple ancestors.

Especially in countries in the Americas, North America and Canada ethnic backgrounds can be diverse and individual ethnicity is increasingly blurred by admixture, making self-reported ethnic background or geographical location less predictive for a correct estimation on a non-normal metabolizer predicted phenotype (130). The probability estimates per country (Figures 2-5) are means of the probability estimates of these different ethnicities and must therefore be interpreted with caution.

The total means are mean probability estimates of all the included populations and represent a worldwide mean probability estimate. Because countries were not weighted by number of inhabitants, small countries with large study populations have a relatively large influence on the estimated mean. In addition, some geographical regions were significantly under-investigated (Africa and the Middle East) and their predicted phenotype distributions are not adequately represented in the total estimated means.

\section{Conclusions}

In this comprehensive meta-analysis of worldwide CYP2D6 and CYP2C19 genotype variation, ( $>336,000$ subjects, 318 reports), we found that the mean total probability estimates for a non-normal metabolizer predicted phenotype are $36.4 \%$ for CYP2D6 and $61.9 \%$ for CYP2C19. The estimates reveal a large geographical variation (3-61\% and $32-80 \%$, respectively). Our results suggest that more than half of the world population has a non-normal CYP2D6 and/or CYP2C19 metabolizer predicted phenotype. Based on the documented probability estimates, pre-emptive pharmacogenetic testing is encouraged for every patient who will undergo therapy with a drug(s) that is metabolized by CYP2D6 and/or CYP2C19 pathways, and should be considered in case of treatment resistance or serious side effects.

Secondly, many of the studies were not relevant for clinical practice, because they only investigated a minimum number of allelic variants and thus any phenotype prediction is unlikely to be accurate. Especially when estimating the prevalence of the CYP2C19 UM predicted phenotype, studies in all regions except for East Asia, should genotype on ${ }^{*} 17$ to come to a reliable phenotype prediction. We therefore recommend that when allele frequencies are being studied, a minimum number of 


\section{Chapter 2}

alleles - depending on the geographical region - must be assessed to be able to predict phenotypes as accurately as possible (153).

\section{Acknowledgments}

We thank Andrea Gaedigk for critical discussion regarding the content. We thank Tale Evenhuis of the University of Leiden and all the members of the library of Parnassia Psychiatric Institute for assisting in the search and collection of articles. In addition, we thank Petra Burgisser for helping import the data into our database, and Mathijs Deen for assisting with the statistics. We thank Judith Offringa for editing a near-final version of the manuscript.

\section{Declaration of interest}

None

\section{Author contributions}

Study conception and design: A.K., D.V., M.B., P.v.H., H.W.H.

Acquisition of data: A.K., D.V.

Analysis and interpretation of data: A.K., D.V., M.B.

Drafting of manuscript: A.K.

Critical revision: D.V., M.B., P.v.H., H.W.H. 


\section{CHAPTER 3}

CYP2D6 and CYP2C19 genotyping in psychiatric patients on psychotropic medication in the former Dutch Antilles

Anne B. Koopmans

David J. Vinkers

Petra J.A. Gelan

Hans W. Hoek

Peter N. van Harten 


\section{Chapter 3}

\section{Abstract}

Aim: This study was aimed to assess the prevalence of CYP2D6 and CYP2C19 polymorphisms in psychiatric patients and in volunteers from Dutch Caribbean origin.

Methods: In total, 435 individuals were genotyped for CYP2D6 and CYP2C19. Of these, 269 were psychiatric patients living in Curaçao and 166 were volunteers from the Dutch Caribbean population.

Results: No differences in prevalence of alleles were found.

Conclusion: Although prevalence of alleles appeared to be very different from African and Caucasian populations, the distribution into predicted phenotypes shows an equal distribution as in Caucasians.

ClinicalTrials.gov: Cost-effectiveness of CYP2D6 and CYP2C19 Genotyping in Psychiatric Patients in Curaçao; Identifier: NCT02713672;

URL: https://clinicaltrials.gov/ct2/show/NCT02713672?term $=$ CYP2D6\&rank $=5$ 


\section{Introduction}

The cytochrome P450 (CYP) is the most important pathway for the metabolization of lipophilic drugs into more hydrophilic compounds, which can be excreted by the kidneys. Humans have 57 genes that encode for over 30 related isoenzymes with different substrate specificities (12). The isoenzymes CYP2D6 and CYP2C19 are highly genetically polymorphic and are specifically related to the metabolism of psychiatric drugs (27-31). Depending on the number of functional alleles, individuals are classified as Poor Metabolizer (PM), Intermediate Metabolizer (IM), Extensive Metabolizer (EM) or Ultrarapid Metabolizer (UM) (6). Because of the lower metabolization ratio, PMs and IMs have higher blood concentrations at recommended dosages of the medication metabolized by the CYP enzymes; this makes them more vulnerable to the dose-dependent adverse effects of psychotropics in normal dosages $(22,24,154-156)$. Simultaneously, exceeding D2 receptor occupancy leads to suboptimal subjective experiences in patients with schizophrenia, leading to less effective treatment (157).

Studies in psychiatric patients found a significant relationship between the CYP2D6 profile and extrapyramidal symptoms $(21,138,158-161)$.

In addition to the role of CYP2D6 genetic polymorphisms in drug metabolism, CYP2D6 is suggested to play a role in the risk for developing a mental disorder. In biochemical studies CYP2D6 was suggested to be functionally similar to the dopamine transporter and to have an endogenous neuroactive substrate or product (162); this has been proposed as an explanation for the relationship found between personality and activity of CYP2D6 (163). Also a lower frequency of poor metabolizers was found among inpatients with schizophrenia (67), although earlier studies did not find these differences $(83,106,164-168)$.

The prevalence of CYP polymorphisms varies considerably across ethnic groups, which leads to great interindividual drugs responses across different ethnicities (57). In Caucasian populations, for example, the prevalence of CYP2D6 UM ranges from $1-10 \%(13,169,170)$ as compared to $20-29 \%$ in specific African populations (81). Allelic variants * 29 and $* 17$ are considered unique to Sub-Saharan African populations (171).

Curaçao is one of the western Leeward Antilles in the Caribbean. Together with Aruba and Bonaire it forms the 'ABC' islands. Until 2010, these islands (together with St Maarten, Saba and St. Eustatius) formed the Netherlands Antilles. The population originates mainly from Western Africa but has admixed with European immigrants and Native South Americans. Recently it has been shown that the complex interactions between the populations in the Caribbean are reflected in a unique composition of genes. Also was shown, that the extensive population stratification implies that medically relevant genetic variants may be geographically restricted (60). 


\section{Chapter 3}

In a recently published systematic review Céspedes-Garro et al. argue that research activity on pharmacogenetics in Caribbean populations is limited and the prevalence of CYP2D6 and CYP2C19 in the former Netherlands Antilles remains unknown (59). Therefore, we investigated the prevalence of CYP2D6 and CYP2C19 in a population from the Dutch Caribbean. To test the hypothesis that CYP2D6 may play a role in the risk for severe psychiatric disorders, we compared the prevalence of CYP2D6 between psychiatric patients on psychotropic medication and individuals from the general population of Dutch Caribbean origin.

\section{Methods}

\section{Setting and study population}

This study was performed on the Caribbean island of Curaçao and also in the Netherlands. The population of Curaçao (approx. 150,000 inhabitants) is mainly of African descent. Participants were recruited from the Klinika Capriles (the only psychiatric hospital on the island), the psychiatric ward of the local prison (FOBA), and the psychiatric outpatient department on the island (Psychiaters Maatschap Antillen). All three institutions provide specialist mental health care and diagnoses are assigned by psychiatrists.

The majority of patients in these institutions are suffering from severe mental illness. Earlier studies in this population showed that $77.3 \%$ of the patients is diagnosed with schizophrenia (8). The objectives of the study were explained to all patients in their native language and they were asked to participate before enrollment. All participants provided written informed consent after explanation of the study, and received a gift token of about 10 euro if they participated.

The study protocol was approved by the Institutional Review Board of Maastricht University (the Netherlands) and ethical approval to collect samples was received according to local policies by the patient board of the Klinika Capriles. The procedures were in accordance with the ethical standards of the Helsinki Declaration of 1975 (as revised in 1983).

Inclusion criteria were: 1) Antillean ethnicity, defined in line with the concepts used by Statistics Netherlands (CBS) as birth on the former Netherlands Antilles and birth of at least one parent on the former Netherlands Antilles, 2) age 18 years or older, 3) use of an antipsychotic or antidepressant drug, and 4) written informed consent. Clinical information about the use of cardiovascular, intramuscular and other medication was also collected. 
To compare our findings with an Antillean population from the general population, we asked Dutch Caribbean visitors at several large Antillean gatherings in the Netherlands for permission to examine their CYP2D6 and CYP2C19 profile. Curaçao is a former Dutch colony and since decennia inhabitants from Curaçao are migrating to the Netherlands. Currently there are as many Antilleans living in the Netherlands as in Curaçao (62). This sample was constructed between June 2012 and March 2013. The inclusion criteria were in line with the Curaçao part of the study, with the exception that no antipsychotic or antidepressant drugs were used. Participants were asked about medication use and their health condition. Participants received a gift token of 25 euro.

We compared the prevalence of the Dutch Caribbean population with populations from Caucasian and African origin. To enable a valid comparison between the prevalence of predicted phenotypes, our results were compared with studies having a similar methodology. Although we searched for studies reporting predicted phenotypes and determining (minimally) the same polymorphisms as in our study, this appeared to be more difficult than expected. Therefore, we decided that Greece and Portugal could represent the Caucasian population, and that Uganda could represent Sub-Saharan Africa (172-174).

To evaluate clinical relevancy of genotyping in psychiatric practice, we evaluated if there were any differences in clinical admission, prison admission, use of intramuscular emergency medication, clozapine, biperidene and cardiovascular medication between the different phenotype groups.

To evaluate possible clinical consequences, patients were selected for dose adjustment based on their CYP2D6 and CYP2C19 genotype. The influence of dose adjustment on psychiatric well-being and side effects was assessed. The results of this study have been reported in a separate paper (88).

\section{CYP2D6 and CYP2C19 genotyping}

Saliva from each participant was collected with a 2-ml cannula OG-500 DNA Genotek. The saliva was kept at room temperature and sent to the Erasmus Medical Center (Rotterdam, the Netherlands) for genotyping. Samples were analyzed using the INFINITI DNA chip (Autogenomics, Carlsbad, CA) for detection of CYP2D6 polymorphisms *1, *2 $(2850 \mathrm{C}>\mathrm{T}$ and $1584 \mathrm{C}>\mathrm{G}), * 3(2549 \mathrm{del}), * 4(1846 \mathrm{G}>\mathrm{A}), * 5$ (deletion), *6 (1707delT), *7 (2935A $>C), * 8(1758 G>T), * 9\left(2615 \_2617\right.$ delAAG), *10 $(100 \mathrm{C}>\mathrm{T}), * 17(1023 \mathrm{C}>\mathrm{T}), * 29(1659 \mathrm{G}>\mathrm{A}), * 41(2988 \mathrm{G}>\mathrm{A})$ and gene duplication. For samples that did not yield a valid result in the INFINITI DNA chip, Taqman (ABI Prism 9700 HT Sequence detection system) and PCR-RFL was used. CYP2C19 polymorphisms *1, ${ }^{*} 2(19154 \mathrm{G}>\mathrm{A})$ and ${ }^{*} 17 \quad(-806 \mathrm{C}>\mathrm{T})$ and duplications were 


\section{Chapter 3}

determined using Taqman and PCR-RFL. The different variants of CYP2D6 and CYP2C19 at the DNA and protein level are described at http://www.cypalleles.ki.se.htm.

Genotypes were grouped according to the Dutch Pharmacogenetic Guideline of the Royal Dutch Association for the Advancement of Pharmacy (consensus meeting). A normal function allele is scored 1 , a reduced function allele is scored 0.5 and a nonfunctional allele scored 0 (http://www.cypalleles.ki.se/CYP2D6.htm). Homozygous carriers of deficient alleles are classified as PMs (0). Carriers with one functional allele and one non-functional allele and homozygous carriers of reduced function alleles are classified as IMs (0.5-1). Homozygous carriers of normal function alleles and carriers of one reduced function and one normal function allele are classified as EMs (1.5-2). Carriers of one or more increased function alleles and carriers of a duplication or multiplication of a functional allele are classified as UMs $(>2)(175,176)$. CYP2D6 polymorphisms * 1 and $* 2$ were classified as $1, * 3-* 8$ as 0 and $* 9, * 10, * 17, * 29$ and *41 as 0.5 . Carriers of two *1 polymorphisms were classified as EMs. Carriers of one CYP2C19*2 polymorphism were classified as IMs and carriers of one and two *17 polymorphisms as UMs. Carriers of $* 2$ in combination with $* 17$ were classified as IMs (47).

\section{Statistical analysis}

Analyses were performed with IBM SPSS statistics (version 22) and GENEPOP $(177,178)$. The significance limit used in all analyses was $a=0.05 . A \chi^{2}$ test was used to make comparisons between the groups in prevalence and clinical parameters. A Fisher exact test was used if expected cell count was lower than 5 . We used a Bonferroni correction if multiple tests were performed. The distributions of the polymorphisms were examined to see if they followed Hardy-Weinberg equilibrium. 


\section{Results}

\section{Curaçao}

From the total inpatient population of 196 patients of the Klinika Capriles (the only psychiatric hospital in Curaçao), 180 (91.8\%) patients met the inclusion criteria and participated in this study. Furthermore, all 10 patients of the forensic psychiatric ward in the local prison, and 79 outpatients who met the inclusion criteria were included, yielding a total of 269 study participants.

Four saliva samples (collected from 3 inpatients at Klinika Capriles and 1 outpatient) were lost during transport to the Netherlands. In 13 samples, CYP2D6 was repeated using Taqman and PCL-RFL. Genotyping succeeded for CYP2D6 in 231 (85.9\%) participants and for CYP2C19 in 187 (69.5\%) participants. Failure of genotyping was due to the low quality DNA obtained from the buccal swabs. Patients in Curaçao were instructed to deliver saliva by the local nurses, which could explain less accurate collection of saliva. The samples, which could not be used for genotyping, had a lack of saliva or were contaminated with food residues. There were no significant differences between those with a successful CYP2D6 or CYP2C19 genotyping and those without regarding gender, place of treatment, use of antipsychotics, antidepressants and other medication.

No differences in clinical admission, prison admission, use of intramuscular emergency medication, clozapine, biperidene and cardiovascular medication were found between the CYP2D6 and CYP2C19 phenotype groups. Age was significantly different between the CYP2C19 phenotype groups (ANOVA $p=0.008$ ). Table 1 presents the characteristics of the different phenotype groups.

Out of the 269 patients, $42.0 \%$ used antipsychotic or antidepressive medication metabolized by CYP2D 6 and $1.5 \%$ used antidepressive medication metabolized by CYP2C19. In total $7.4 \%$ of the patients were using CYP2D6 or CYP2C19 inhibiting medication. 


\begin{tabular}{|c|c|c|c|c|c|c|c|}
\hline \multirow{2}{*}{$\begin{array}{l}\text { Patient } \\
\text { characteristics }\end{array}$} & \multicolumn{4}{|c|}{ CYP2D6, n (\%) } & \multicolumn{3}{|c|}{ CYP2C19, n (\%) } \\
\hline & $\begin{array}{l}\text { PM, } n=13 \\
(5.6)\end{array}$ & $\begin{array}{l}\text { IM, } n=73 \\
(31.6)\end{array}$ & $\begin{array}{l}E M, n=139 \\
(60.2)\end{array}$ & $\begin{array}{l}\text { UM, } n=6 \\
(2.6)\end{array}$ & $\begin{array}{l}\text { IM, } n=55 \\
(29.4)\end{array}$ & $\begin{array}{l}E M, n=79 \\
(42.2)\end{array}$ & $\begin{array}{l}\text { UM, } n=53 \\
(28.3)\end{array}$ \\
\hline Male & $6(46.2)$ & $49(67.1)$ & $90(64.7)$ & $5(83.3)$ & $39(70.9)$ & $52(65.8)$ & $38(71.7)$ \\
\hline Age & 48.08 & 49.74 & 48.59 & 39.67 & 45.89 & 51.42 & 45.30 \\
\hline Inpatient & $7(53.8)$ & $45(61.6)$ & $97(69.8)$ & $1(16.7)$ & $36(65.5)$ & $53(67.1)$ & $39(73.6)$ \\
\hline Outpatient & $5(38.5)$ & $24(32.9)$ & $38(27.3)$ & $4(66.7)$ & $16(29.1)$ & $21(26.6)$ & $12(22.6)$ \\
\hline Prison & $1(7.7)$ & $4(5.5)$ & $4(2.9)$ & $1(16.7)$ & $3(5.5)$ & $5(6.3)$ & $2(3.8)$ \\
\hline $\begin{array}{l}\text { Intramuscular } \\
\text { emergency } \\
\text { medication }\end{array}$ & $2(18.2)$ & $9(14.1)$ & $17(144)$ & $1(16.7)$ & $5(9.4)$ & $13(17.3)$ & $6(12.2)$ \\
\hline Clozapine & $1(9.1)$ & $9(14.1)$ & $16(13.7)$ & $1(16.7)$ & $7(13.5)$ & $11(14.7)$ & $6(12.2)$ \\
\hline Biperidene & $4(36.4)$ & $26(40.6)$ & $42(35.6)$ & $1(16.7)$ & $17(32.1)$ & $34(45.3)$ & $16(32.7)$ \\
\hline $\begin{array}{l}\text { Cardiovascular } \\
\text { medication }\end{array}$ & $3(27.3)$ & & & & $14(26.4)$ & $27(36.5)$ & $10(20.8)$ \\
\hline $\begin{array}{l}{ }^{+} \text {CYP2D } 6 \text { genotyping } \\
\text { EM: Extensive metab }\end{array}$ & $\begin{array}{l}=231 ; \text { CYP2C } \\
\text { zer; IM: Interm }\end{array}$ & genotyping $n=$ & $\begin{array}{l}=187 . \\
\text { er; PM: Poor me }\end{array}$ & 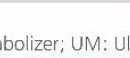 & 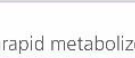 & & \\
\hline
\end{tabular}

\section{The Netherlands}

In the Netherlands, 166 Dutch Caribbean participants were genotyped. These participants were selected from the general population, 68 (41.0\%) were using medication (mostly cardiovascular drugs). The CYP2D6 could not be established in three persons and the CYP2C19 genotype remained unknown in 21 persons.

\section{Genotypes}

In total, 435 Dutch Caribbean persons from two samples were genotyped. The genotyping was in both groups in concordance with Hardy-Weinberg equilibrium (psychiatric patients in Curaçao; CYP2D6 p =0.07, CYP2C19 p=0.38; Dutch Caribbeans in the Netherlands; CYP2D6 $\mathrm{p}=0.28$, CYP2C19 $\mathrm{p}=0.92)$.

There were no differences between the Dutch Caribbean psychiatric group from Curaçao and the Dutch Caribbean non-psychiatric group living in the Netherlands in gender. Mean age was higher in the psychiatric patients group 49.5 (13.0) versus 44.6 (15.9) years $(p=0.0005)$.

No significant differences in CYP2D6 and CYP2C19 allelic frequency between the two groups were found. The frequencies of the CYP2D6 predicted phenotypes showed an equal distribution between the two groups. In the Dutch Caribbean nonpsychiatric group living in the Netherlands there were significantly more CYP2C 19 
poor metabolizers than in the Dutch Caribbean psychiatric group from Curaçao (Fisher exact $\mathrm{p}=0.02$ ).

Table 2 and 3 present these results, compared with other ethnic populations. CYP2D6*17 was the most prevalent mutant allele (16.2\%). The most frequent nonfunctioning CYP2D 6 allele was *4. Table 4 presents the prevalence of the predicted phenotypes.

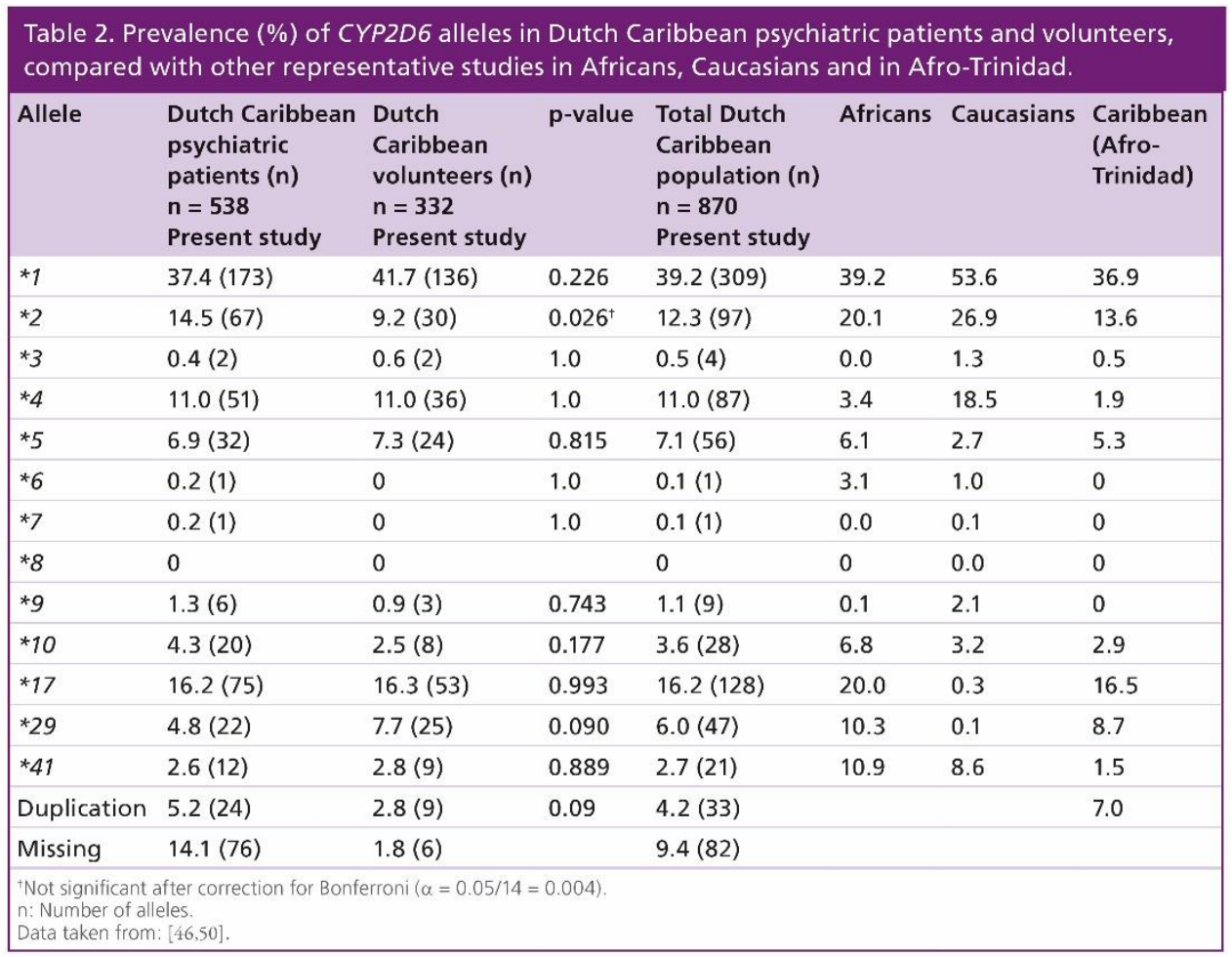




\section{Chapter 3}

Table 3. Prevalence (\%) of CYP2C19 alleles in Dutch Caribbean psychiatric patients and volunteers, compared with other representative studies in Africans and Caucasians.

\begin{tabular}{|c|c|c|c|c|c|c|}
\hline Allele & $\begin{array}{l}\text { Dutch Caribbean } \\
\text { psychiatric patients } \\
\text { (n) } n=538 \\
\text { Present study }\end{array}$ & $\begin{array}{l}\text { Dutch Caribbean } \\
\text { volunteers }(n) \\
n=332 \\
\text { Present study }\end{array}$ & $p$-value & $\begin{array}{l}\text { Total Dutch Carib- } \\
\text { bean population }(\mathrm{n}) \\
\mathrm{n}=870 \\
\text { Present study }\end{array}$ & Africans & Caucasians \\
\hline$* 1$ & $67.1(251)$ & $61.4(178)$ & 0.125 & $64.6(429)$ & 68.0 & 63.0 \\
\hline$* 2$ & $14.7(55)$ & $16.2(47)$ & 0.595 & $15.4(102)$ & 15.0 & 15.0 \\
\hline$* 17$ & $18.2(68)$ & $22.4(65)$ & 0.177 & $20.0(133)$ & 16.0 & 21.0 \\
\hline Duplication & - & - & & - & & \\
\hline Missing & $30.5(164)$ & $12.6(42)$ & & $23.7(206)$ & & \\
\hline
\end{tabular}

Table 4. Prevalence (\%) of CYP2D6 and CYP2C19 phenotypes in Dutch Caribbean persons compared with other representative studies in Africans and Caucasians.

\begin{tabular}{|c|c|c|c|c|c|c|c|c|c|c|c|c|}
\hline \multirow[t]{2}{*}{ Phenotype } & \multicolumn{6}{|c|}{ CYP2D6 } & \multicolumn{6}{|c|}{ CYP2C19 } \\
\hline & $\begin{array}{l}\text { Dutch } \\
\text { Caribbean } \\
\text { psychiatric } \\
\text { patients }(n) \\
n=269 \\
\text { Present study }\end{array}$ & $\begin{array}{l}\text { Dutch } \\
\text { Caribbean } \\
\text { volunteers } \\
(n) n=166 \\
\text { Present } \\
\text { study }\end{array}$ & p-value & $\begin{array}{l}\text { Total Dutch } \\
\text { Caribbean } \\
\text { population } \\
\text { (n) } n=435 \\
\text { Present } \\
\text { study }\end{array}$ & $\begin{array}{l}\text { Africans } \\
\text { (Sub- } \\
\text { Saharan) } \\
\text { (n) }\end{array}$ & $\begin{array}{l}\text { Caucasians } \\
\text { (Portugal) } \\
\text { (n) }\end{array}$ & $\begin{array}{l}\text { Dutch } \\
\text { Caribbean } \\
\text { psychiatric } \\
\text { patients }(n) \\
n=269 \\
\text { Present study }\end{array}$ & $\begin{array}{l}\text { Dutch } \\
\text { Caribbean } \\
\text { volunteers } \\
(n) n=166 \\
\text { Present study }\end{array}$ & p-value & $\begin{array}{l}\text { Total Dutch } \\
\text { Caribbean } \\
\text { population }(n) \\
n=435 \\
\text { Present study }\end{array}$ & $\begin{array}{l}\text { Africans } \\
\text { (Uganda) }\end{array}$ & $\begin{array}{l}\text { Caucasians } \\
\text { (Greece) }\end{array}$ \\
\hline PM & $5.6(13)$ & $4.3(7)$ & 0.553 & $5.0(20)$ & $1.24(7)$ & $6.3(19)$ & $0(0)$ & $4.1(6)$ & 0.007 & $1.8(6)$ & 2 & 2.1 \\
\hline IM & $31.6(73)$ & $32.5(53)$ & 0.848 & $32.0(126)$ & & $32.7(98)$ & $29.4(55)$ & $24.1(35)$ & 0.284 & $27.1(90)$ & 23 & 22.0 \\
\hline EM & 60.1 (139) & $61.3(100)$ & 0.814 & $60.7(239)$ & & $56.3(169)$ & $42.2(79)$ & $37.2(54)$ & 0.356 & $40.0(133)$ & 51 & 44.1 \\
\hline UM & $2.6(6)$ & $2.6(3)$ & 0.620 & $2.3(9)$ & $6.74(43)$ & $4.7(14)$ & $28.3(53)$ & $34.5(50)$ & 0.230 & $31.0(103)$ & 24 & 31.8 \\
\hline Missing & $14.1(38)$ & $1.8(3)$ & & $9.0(41)$ & & & $30.5(82)$ & $12.7(21)$ & & $23.7(103)$ & & \\
\hline
\end{tabular}




\section{Discussion}

\section{Comparison with other ethnicities}

To our knowledge, this is the first study to investigate the prevalence of the polymorphisms of CYP2D6 and CYP2C19 in this specific Caribbean population. The former Netherlands Antilles have a long history of different ancestors and the current population is very heterogeneous. Arawaks were the native inhabitants before Europeans colonized the island and brought slaves from West Africa to the island. Immigrants from Latin America, other Caribbean islands and East Asia, came to the islands after slavery was abolished and admixed with the local inhabitants (179). Moreno-Estrada et al. found that this admixture can result in geographically restricted medically relevant genetic variations (60). Therefore, it is important to investigate the impact of this admixture of ancestors on allele composition.

One difficulty in comparing our prevalence rates with others is the ongoing detection of unknown mutations, which has resulted in overestimation of the prevalence of wild type genotype, namely CYP2D $6^{*} 1$ and CYP2C19*1. To allow to predict the correct phenotype in patients of all nationalities, we tested for the most common gene mutations worldwide; CYP2D $6 * 1, * 2, * 3, * 4, * 5, * 6, * 7, * 8, * 9, * 10, * 17, * 29, * 41$ and CYP2C19*1, ${ }^{*} 2 * 17(180)$. (180). CYP2C19*17 is a relatively novel variant causing ultrarapid metabolism and is responsible for the overestimation of extensive metabolizers in many studies (174). In the present study we found a high prevalence of CYP2C19*17, i.e. $20.0 \%$.

Furthermore, noteworthy is the relatively high prevalence of CYP2D6*4 of $11.0 \%$. In Sub-Saharan African populations non-functional alleles as * 4 occur at a relatively low frequency with a median rate of $3.36 \%$. Only in the Ghanaian population a higher rate of $7 \%$ is reported (57). This is interesting because the ancestors of the inhabitants of Curaçao are suggested to originate mainly from West Africa, which could imply a Ghanaian heritage (179). Another explanation could be heritage from the Dutch colonists because, in Caucasians, the polymorphism is relatively prevalent (18.5\%) (176). In the present study, the frequency of CYP2D6 alleles is similar to that in an Afro-Caribbean population from Trinidad and Tobago - who are also suggested to originate from (West) Africa - except for the prevalence of $* 4$, which is $1.94 \%$ in Trinidad and Tobago [45].

Reduced function allele CYP2D6 *17 occurs at a prevalence of $16.2 \%$ in Curaçao compared to $20 \%$ in Sub-Saharan Africa and a very low prevalence of $0.32 \%$ in Caucasians (176). CYP2D6*10, which can be as high as $74 \%$ in Asian populations, is not as prevalent in the Curaçao population (i.e. 3.6\%) (114). This suggests that the inhabitants of the former Netherlands Antilles are mainly an admixture of Caucasians and Sub-Saharan Africans, with much less admixture between descendants of the African slaves and the Asian immigrants. 


\section{Chapter 3}

The prevalence of the polymorphisms CYP2C19 is less widely distributed among the different ethnicities. With a prevalence of normal function CYP2C19 *1 of $64.6 \%$ in inhabitants of the Dutch Caribbean, this almost equals the prevalence of $68 \%$ in Africans and $63 \%$ in Caucasians. Reduced function allele *2 and *17 are prevalent in amounts similar to those in Africans and Caucasians (181).

Comparison of the predicted phenotypes with other ethnicities provides interesting insights: even though CYP2D6 genotypes differ greatly between the investigated population and Caucasians, the prevalence of predicted phenotypes is very similar.

\section{Comparison between psychiatric patients and general population}

We found no difference between the allelic frequencies in the cohort of psychiatric patients versus a comparable group of non-psychiatric Dutch Caribbean volunteers. Several clinical studies found lower frequencies of CYP2D6 poor metabolizers in admitted patients with schizophrenia $(22,67)$, whereas other did not find this difference $(83,106,164-168)$. A possible explanation for this is that CYP2D6 plays a role in the biotransformation of several neurotransmitters. CYP2D6 may be involved in the formation of dopamine from tyramine and therefore contributes to vulnerability for schizophrenia and may have influence over personality $(140,162)$. There is, however, no evidence that these biochemical processes occur in psychiatric patients.

In the present study, almost $30 \%$ of the psychiatric population is outpatient. Moreover, because the control group is from the same ethnic background, our findings are not influenced by ethnic differences. The studies which found a difference investigated a selected inpatient population compared with healthy outpatient volunteers $(22,67)$. In patients with depression it was shown that length of hospitalization is correlated with CYP2D6 functional status (5). The selection of inpatients might have confounded the results. In our population there were no differences in predicted phenotype frequencies between in and outpatients.

We found no CYP2C19 poor metabolizers in psychiatric patients in contrast to $4.1 \%$ in the healthy volunteers. The absence of CYP2C19 poor metabolizers is also reported in Panamanian Indian and Mexican populations $(182,183)$. The Indian in heritage could be an explanation for the low prevalence among our subjects. There is no convincing relationship between CYP2C19 and psychiatric symptoms(46). Although in a Swedish population poor metabolizers had significantly lower levels of depressive symptoms than extensive metabolizers, with a stronger relationship in the younger age groups (184). This might also have influenced the mean age in our psychiatric population. 


\section{Limitations}

A limitation of this study is the selection of a heterogeneous group of psychiatric patients. We have not investigated the prevalence of CYP2D6 or CYP2C19 in specific psychiatric disorders. Since we wanted to investigate the prevalence in a group for which results could have clinical implications, we investigated prevalence in all patients with a psychiatric disorder and use of psychotropic medication.

Another important limitation of this study is the relatively large percentage of missing saliva samples as compared to studies investigating DNA by blood sampling. However, because genotyping from saliva is non-invasive, we were able to genotype a large cohort of individuals. Unfortunately, genotyping of CYP2C19 failed in of 24\% of the samples. Nevertheless, because no differences were found between the successfully genotyped group and the group with missing genotype and results are within expected frequencies of the HWE, missing data are not expected to have influenced our results.

A third limitation is the relatively small sample size of the study because of the small percentages we found for some CYP2D6 polymorphisms. For this reason, these findings cannot be generalized to the broader community based on this study alone.

\section{Conclusion}

In summary, this study reveals a unique composition of alleles in the population of the former Netherlands Antilles. The complex admixture of ancestors was shown in the unique composition of alleles of CYP2D6. Although we found a completely different allele composition than found in Caucasians, the translation into predicted phenotypes shows an almost similar distribution between these groups.

No differences in allelic frequency were found between psychiatric patients and nonpsychiatric volunteers. Although a higher frequency of CYP2C19 poor metabolizers was observed in the non-psychiatric volunteer group.

These findings imply that, in clinical practice the same attention should be paid to altered drug clearance in (former) inhabitants from the Dutch Caribbean, as is paid to Caucasians. 


\section{Chapter 3}

\section{Summary points}

- We found a unique prevalence of specific CYP2D6 and CYP2C19 alleles in the Dutch Caribbean population.

- $\quad$ The most frequent non-functioning CYP2D6 allele in the Dutch Caribbean population is * 4 .

- $\quad$ The most frequent variant CYP2C 19 allele causing ultrarapid metabolism in the Dutch Caribbean population is * 17 .

- No significant difference was found in the alleles in psychiatric and nonpsychiatric Dutch Caribbean subjects.

- No significant difference was found for variability of CYP2D6 activity between the Dutch Caribbean population and Caucasian populations.

- $\quad$ There were significantly more CYP2C19 poor metabolizers in the Caribbean non-psychiatric volunteer group.

- $\quad$ The same attention should be paid to altered drug clearance in inhabitants from the Dutch Caribbean, as is paid to Caucasians.

- $\quad$ Our findings provide further evidence for geographic-specific admixture and uniqueness and heterogeneity of populations of Caribbean descent. 


\section{Acknowledgments}

The authors thank F.G.M. Heijtel MD and G.M. Matroos MD, psychiatrists at the Psychiaters Maatschap Antillen, and also staff at the Klinika Capriles and the psychiatric ward of the local prison in Curaçao for facilitating recruitment.

Reproduced from Pharmacogenomics (2017) 18:1003-1012. doi:10.2217/pgs-20170011 with permission of Future Medicine Ltd.

\section{Financial disclosures}

This study was funded by ZonMW, the Netherlands Organisation for Health Research and Development (Protocol ID 70-72600-98-005). The authors have no other relevant affiliations or financial involvement.

\section{Ethical conduct of research}

The authors state that they have obtained appropriate institutional review board approval and have followed the principles outlined in the Declaration of Helsinki for all human or animal experimental investigations. In addition, informed consent has been obtained from the participants involved. 



\title{
CHAPTER 4
}

No effect of dose adjustment to the CYP2D6 genotype in patients with severe mental illness

\author{
Anne B. Koopmans \\ David J. Vinkers \\ Igmar T. Poulina \\ Petra J.A. Gelan \\ Ron H.N. van Schaik \\ Hans W. Hoek \\ Peter N. van Harten
}

Front Psychiatry (2018) 9 (August) doi:10.3389/fpsyt.2018.00349 


\section{Chapter 4}

\section{Abstract}

Background The CYP2D6 enzyme is involved in the metabolism of numerous psychopharmacological drugs. Guidelines recommend how to adjust the dose of medication based on the CYP2D6 genotype.

Aims To evaluate the effect of dose adjustment to the CYP2D6 genotype and phenotype, in patients with severe mental illness (SMI) already receiving psychopharmacological treatment.

Method A total of 269 psychiatric patients (on the island Curaçao) receiving antipsychotic treatment were genotyped for CYP2D6. Of these, 45 patients were included for dose adjustment according to the clinical guideline of the Royal Dutch Association for the Advancement of Pharmacy, i.e. 17 CYP2D6 poor metabolizers, 26 intermediate metabolizers, and 2 ultrarapid metabolizers. These 45 patients were matched for age, gender and type of medication with a control group of 41 patients who were CYP2D6 extensive metabolizers (i.e. with a normal CYP2D6 function). At baseline and at 4 months after dose adjustment, subjective experience, psychopathology, extrapyramidal side-effects, quality of life, global functioning were assessed in these two groups.

Results At baseline, there were no differences between the groups regarding the prescribed dosage of antipsychotics, the number of side-effects, psychiatric symptoms, global functioning or quality of life. After dose adjustment, no significant improvement in these parameters was reported.

Conclusion In psychiatric patients with $\mathrm{SMI}$ already receiving antipsychotic treatment, dose adjustment to the CYP2D6 genotype or phenotype according to the guidelines showed no beneficial effect. This suggest that dose adjustment guidelines are currently not applicable for patients already using antipsychotics.

Keywords: CYP2D6, severe mental illness (SMI), guidelines, dose adjustment, genotyping, psychopharmacology, personalized medicine 


\section{Introduction}

The cytochrome P450 isozymes, in particular CYP2D6, is responsible for the biotransformation of many psychopharmacological drugs $(12,13)$. Substrates of CYP2D6 include first generation antipsychotics, selective serotonin receptor inhibitors and tricyclic antidepressants ${ }^{1}$. Based on genetic variation, patients can be divided into poor metabolizers (PM), intermediate metabolizers (IM), extensive metabolizers (EM) and ultrarapid metabolizers (UM). The recommended dosages of psychopharmacological medication that are metabolized by this enzyme are based on the metabolism of the most common genotype, i.e. the EM type (i.e. a normal CYP2D6 function). However, because the plasma level of a drug is related to the genotype, the same dosage will probably lead to a higher plasma level in PMs and IMs, as compared to EMs, and to a lower plasma level in UMs as compared to EMs. The plasma level is often related to the effectiveness of the drug and the risk of doserelated side-effects $(20-23,25)$. Also, when physicians prescribe a drug metabolized by CYP2D6 without taking into account the genotype, the hospital stay is longer (and the costs higher) in patients with a PM and UM profile(5).

Clinical guidelines recommend dose adjustment according to the CYP2D6 genotype $(44,85,185)$. However, the current guidelines do not differentiate between patients that start versus those that are already receiving psychopharmacological treatment. Patients with severe mental illness (SMI) are especially known to suffer from problems with adverse drug reactions, lack of medication effect, and new models of care are warranted $(1,68-70,186)$. In a study in patients with SMI, more adverse drug events and higher costs were found in the extreme metabolizer groups(42). In a cost analysis study it was found that genotyping in patients with schizophrenia could lead to lower treatment costs (7).

Genotyping in patients with SMI could potentially individualize treatment, reduce side-effects in slower metabolizers and increase treatment effects in rapid metabolizers. Until now, it remains unclear whether routine CYP2D6 genotyping is efficacious in patients with SMI already undergoing psychopharmacological treatment and evidence of clinical utility of CYP2D6 genotyping in patients being prescribed antipsychotics is lacking $(6,27,187)$. We hypothesized that dose adjustment of antipsychotics to the CYP2D6 genotype and phenotype would be beneficial regarding side-effects, psychiatric symptoms, quality of life, and/or global functioning. The aim of the present study was to evaluate the effect of dose adjustment to the CYP2D6 genotype and phenotype, in patients with SMI already receiving psychopharmacological treatment. The dose adjustment group consisted of patients with a PM, IM or UM profile using antipsychotics metabolized by CYP2D6, whereas the control group consisted of patients with an EM geno-/ phenotype. The effect of dose adjustment of the antipsychotics on psychopathological symptoms, side-effects and well-being was evaluated. 


\section{Chapter 4}

\section{Methods}

\section{Patients}

This study was performed on the Caribbean island, Curaçao: this is one of the western Leeward Antilles in the Caribbean with about 160,000 inhabitants ${ }^{2}$. Patients were recruited via the Klinika Capriles (the psychiatric hospital on the island), the psychiatric ward of the local prison (FOBA), and the psychiatric outpatient clinic (Psychiaters Maatschap Antillen).

After being informed about the study procedures, all patients signed written informed consent. Inclusion criteria were: Antillean ethnicity (defined in line with the concepts used by the Central Office of Statistics in the Netherlands, as birth on the former Netherlands Antilles and birth of at least one parent on the former Netherlands Antilles); age $\geq 18$ years; use of an antipsychotic or antidepressant drug; able and written informed consent. All participants in both groups received a token for 25 Netherlands Antillean Guilder (about US \$13) if they completed the study.

All DNA samples were genotyped July 2012 for CYP2D6 *1, *2, *3, *4, *5, *6, *7, *8, $* 9$, *10, *17, *29,*41 in the Erasmus Medical Center (Rotterdam, the Netherlands) and gene duplication and grouped according to the predicted phenotype for CYP2D6 as described earlier (188).

Diagnoses, demographic information and information on psychiatric and somatic medication was derived from the electronic patient file. The following psychiatric drugs were considered to have a major dependence on the CYP2D6 enzyme for their elimination: amitriptyline, aripiprazole, atomoxetine, clomipramine, imipramine, haloperidol, nortriptyline, paroxetine, pimozide, risperidone, venlafaxine and zuclopenthixol $(44,85)$.

Based on the CYP2D6 genotype or phenotype, patients were selected who were recommended a dose adjustment of their psychopharmacological medication according to the guideline of the Royal Dutch Association for the Advancement of Pharmacy (updated until July 2013). In this guideline, recommendations were developed for 53 drugs based on a systematic review of the literature. In CYP2D6 PM, IM or UM patients, using medication metabolized by CYP2D6, it is advised to switch to a drug that is not metabolized by CYP2D6. An alternative is to adjust the dosage with dose reductions of respectively 25 to $50 \%$ of the original dose in IMs and PMs $(44,85)$.

To increase the power of the present study, patients who were PM or IM based on inhibiting medication were also included in the dose adjustment group (189). 
Patients using strong CYP2D6 inhibitors (bupropion, cinacalcet, fluoxetine, paroxetine, quinidine) according to Flockhart's interaction table, were classified as being PM $(176,189)$.

The selected patients were matched for age, gender and type of medication with a control group of patients who were CYP2D6 extensive metabolizers.

All prescribed antipsychotics were calculated to a 'defined daily dose' (DDD) as reported by the World Health Organization (WHO) (190). This is a unit of measurement and defined as the assumed average maintenance dose per day for a drug used for its main indication in adults. The total equivalent of the DDD was calculated for every patient. The study protocol was approved by the Institutional Review Board of Maastricht University (the Netherlands) and ethical approval to collect DNA samples was received according to local policies by the institutional review board of the Klinika Capriles (Curaçao).

The study was registered in an international trial registry at http://www.clinicaltrials.gov (NCT02713672). All procedures were in accordance with the ethical standards of the Declaration of Helsinki 1975 (as revised in 1983).

\section{Assessments}

Each patient underwent a thorough assessment of psychopathology, subjective experience, extrapyramidal symptoms, quality of life, global functioning and metabolic parameters at baseline (T0) (November-December 2014) and at four months after dose adjustment (T1) (April-June 2015). Information about drug and alcohol use was registered.

The severity of the patient's psychopathology was assessed with the Brief Psychiatric Rating Scale (BPRS) (191). Extrapyramidal symptoms were assessed with the St. Hans Rating Scale (SHRS) (192). Akathisia was measured with the Barnes Rating Scale for drug-induced akathisia (BARS) $(193,194)$. Quality of life was assessed with the EQol 5-D (EQ 5-D) (195). Global functioning was assessed with the WHO Disability Assessment Schedule 2.0 36-item proxy-administered version (WHODAS 2.0) and was administered with a personal caregiver $(196,197)$; scores were recalculated to a standardized score. In all above-mentioned scales, higher scores indicate more severe symptoms. Subjective experience was measured with the Subjective WellBeing Under Neuroleptics Scale (SWN-20) (198). Scores were recalculated, with higher scores indicating a higher level of well-being. For patients who were unable to read Dutch, the questions were translated into Papiamento (a local language). The investigator, a resident in psychiatry, was trained by professionals in scoring the SHRS, BARS and the WHODAS 2.0. Patients receiving depot medication were 


\section{Chapter 4}

measured the same number of days after administration of the depot at T0 and at T1.

Secondary outcome measurements were metabolic parameters (blood pressure, body mass index (BMI), waist size, cholesterol, HDL, LDL, triglycerides, glucose, $\mathrm{HbA} 1 \mathrm{C}$ and prolactin) and in 31 of the 60 patients receiving antipsychotics metabolized by CYP2D6 (dose adjustment group $n=22$, control group $n=9$ ), the plasma levels of antipsychotics were measured.

\section{Procedures}

After baseline measurements, another psychiatrist in training prescribed the dose adjustments. A standard procedure for dose adjustments was followed. Lowering the dose was done in steps according to a local protocol ${ }^{3}(199)$. Tranquilizing medication with inhibitory activity was replaced by benzodiazepines. By removing the inhibiting medication, no further dose reduction was necessary in these patients. Complex cases were discussed with the research team during a regular meeting and individual dose adjustment plans were made.

\section{Statistical analysis}

Analyses were performed with IBM SPSS statistics (version 22). Differences between groups were tested with a Chi-square test for dichotomous variables and an independent t-test for continuous variables. ANOVA was used to compare means between the geno-/phenotypes. Non-parametric tests were used for variables not normally distributed (i.e. SHRS, BARS, EQ 5-D). Differences at T1 that were present at T0 were corrected for in an ANCOVA model. The relation between geno-/pheno and DDD was investigated with Kendall's tau. All tests were two-tailed. The significance level was set at $p<0.05$. After Bonferroni correction, the significance level used was $\mathrm{p}<0.005(0.05 / 11)$.

To analyse all aspects of deterioration, psychiatric well-being was evaluated on (one of) three scored items: i.e. deterioration was defined as a specific report by caregivers or a physician, or a >5-point increase on the BPRS, or on the WHODAS 2.0.

A post-hoc power analysis showed that a $25 \%$ reduction of the psychiatric symptoms, or a $30 \%$ reduction of the symptoms measured by WHODAS 2.0 , or a $75 \%$ reduction of the Parkinson symptoms, results in a power of $80 \%$ at a significance level of 0.05 . 


\section{Results}

\section{Baseline characteristics}

The study population consisted of 269 long-term psychiatric patients, of which $94 \%$ was diagnosed with a psychotic disorder. Other diagnoses were major depressive disorder, bipolar disorder, substance abuse and intellectual disability. No regular drug or alcohol use was reported in any of the questionnaires. A quarter of the patients was outpatient. The majority (92\%) was admitted in a long-term treatment facility or institutional housing at the start of genotyping and had a long treatment history. Every patient was genotyped 2.5 years before the start of the intervention, and for at least this period in treatment. Patients were stable on antipsychotic treatment for at least 2.5 years, three patients switched once from antipsychotic during this treatment period.

Genotyping succeeded in 231 participants. Failure of genotyping was due to the low quality DNA obtained from the buccal swabs. Frequencies of PMs, IMs and UMs were similar to those found in an Antillean population without psychiatric disease(188); Caucasian populations(188); and in patients using antipsychotic medication not metabolized by CYP2D6.

In total 111 out of 269 patients were using medication metabolized by CYP2D6. In total, 153 patients were prescribed two types of antipsychotics and 24 patients used antidepressant medication. Because the admitted patients received their medication from the nurses and two third of the patients were using depot medication we could account for medication adherence in $90 \%$ of the included patients. Figure 1 presents an overview of the patient selection and study procedure. The medication in the dose adjustment group was haloperidol $(n=15)$, risperidone $(n=21)$ and zuclopenthixol $(n=9)$. 


\section{Chapter 4}

Figure 1. Study procedure and inclusion of participants

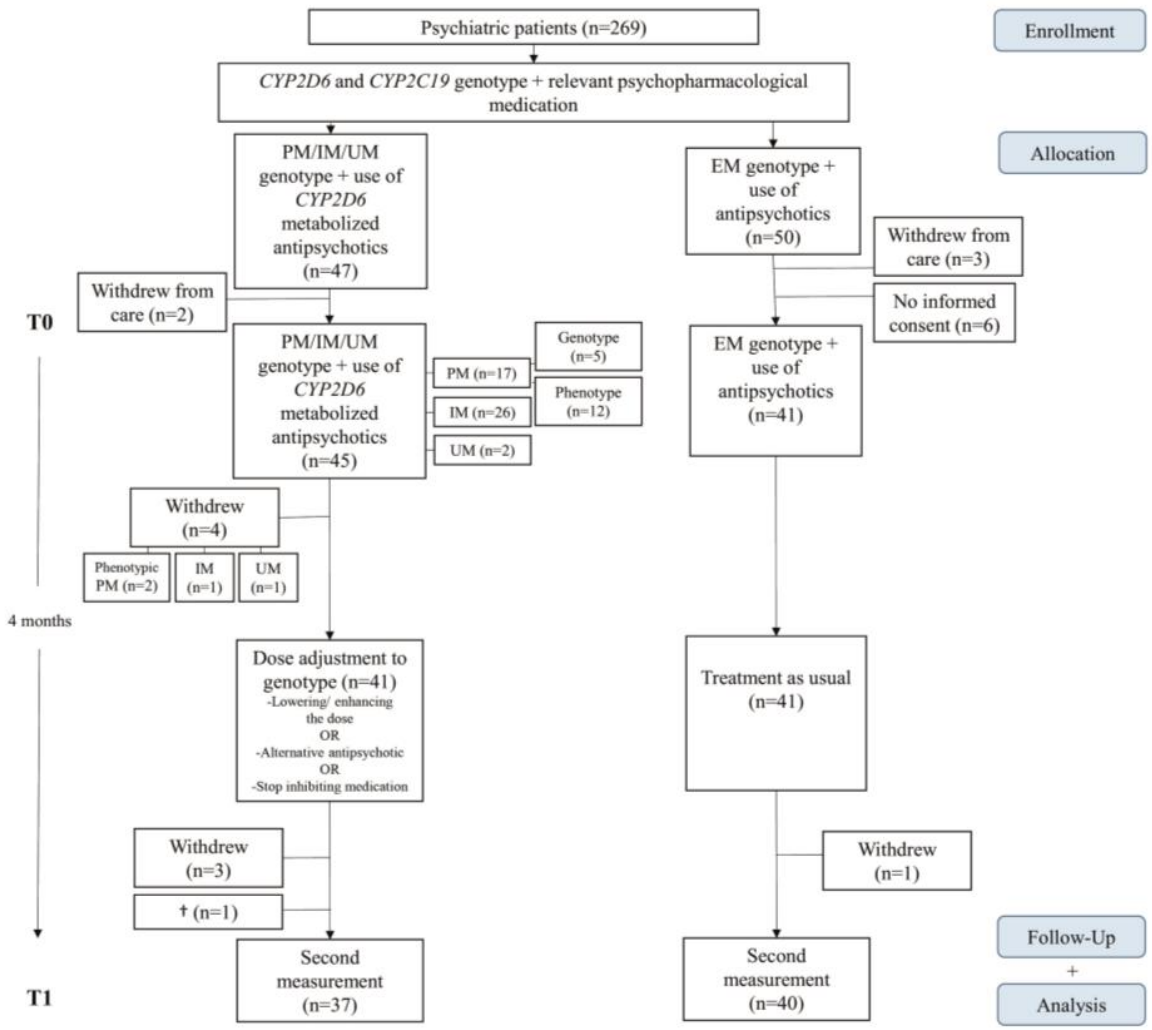

$\mathrm{PM}=$ poor metabolizer; $\mathrm{IM}=$ Intermediate Metabolizer, $\mathrm{UM}=$ Ultrarapid Metabolizer; $\mathrm{EM}=$ Extensive Metabolizer

Out of 41 patients, 16 patients received a dose reduction. The mean dose reduction was $0.60 \mathrm{DDD}$, (1.4 DDD in PMs, $0.54 \mathrm{DDD}$ in IMs) which equals a reduction from 5 to $2 \mathrm{mg}$ risperidone. Other patients stopped with their inhibiting medication or received alternative antipsychotic medication. Table 1 presents the patient characteristics and the outcome of measurements at T0 and T1.

Four months after dose adjustment (T1), 81 (94\%) patients were assessed for the follow-up measurements; one patient had died of cancer, two patients had withdrawn from psychiatric care, and two patients did not want to participate a second time. 
TABLE 1 | Clinical characteristics, baseline, and delta scores of the dose adjustment and control group.

\begin{tabular}{|c|c|c|c|c|c|c|}
\hline & $\begin{array}{c}\text { T0 } \\
\text { dose adjustment group } \\
n=45 \\
\text { Mean (SD) }\end{array}$ & $\begin{array}{c}\text { T0 } \\
\text { control group } \\
n=41 \\
\text { Mean (SD) }\end{array}$ & $p$-value ${ }^{\star}$ & $\begin{array}{c}\text { T1-T0 } \\
\text { dose adjustment group } \\
n=37 \\
\text { Mean (SD) }\end{array}$ & $\begin{array}{c}\text { T1-T0 } \\
\text { control group } \\
n=40 \text { Mean }(S D)\end{array}$ & $p$-value \\
\hline Male $(n)$ & 30 & 25 & 0.58 & & & \\
\hline Female $(n)$ & 15 & 16 & 0.58 & & & \\
\hline Age (years) & $52.4(12.0)$ & $50.3(10.8)$ & 0.15 & & & \\
\hline Depot medication & 30 & 27 & 0.59 & & & \\
\hline Outpatient & 14 & 9 & 0.34 & & & \\
\hline Defined daily dose & 1.65 & 1.92 & 0.17 & & & \\
\hline $\begin{array}{l}\text { BPRS: } \\
24 \text { items (1-7) }\end{array}$ & $1.79(0.51)$ & $1.66(0.43)$ & 0.26 & $-0.26(0.26)$ & $-0.17(0.27)$ & 0.15 \\
\hline $\begin{array}{l}\text { SWN-20: } \\
20 \text { items }(1-6)\end{array}$ & $4.59(0.95)$ & $4.45(1.02)$ & 0.59 & $0.29(0.66)$ & $-0.06(0.57)$ & 0.04 \\
\hline $\begin{array}{l}\text { WHODAS 2.0: } \\
32 \text { items (1-5) (standardized } \\
\text { total score) }\end{array}$ & $32.06(16.28)$ & $30.40(16.89)$ & 0.69 & $5.47(17.50)$ & $2.93(10.63)$ & 0.52 \\
\hline $\begin{array}{l}\text { EQ 5-D: } \\
5 \text { items (1-3) }\end{array}$ & $1.30(0.31)$ & $1.31(0.38)$ & 0.78 & $-0.07(0.37)$ & $-0.05(0.24)$ & 0.74 \\
\hline $\begin{array}{l}\text { Dyskinesia SHRS: } \\
18 \text { items: }(0-6)\end{array}$ & $0.61(0.70)$ & $0.78(0.87)$ & 0.58 & $0.19(0.55)$ & $0.045(0.57)$ & 0.33 \\
\hline $\begin{array}{l}\text { Parkinsonism SHRS: } \\
10 \text { items }(0-6)\end{array}$ & $0.97(1.12)$ & $1.00(1.33)$ & 0.70 & $0.47(0.76)$ & $0.04(0.72)$ & 0.05 \\
\hline $\begin{array}{l}\text { Dystonia SHRS: } \\
2 \text { items (0-6) }\end{array}$ & $0.06(0.34)$ & $0.27(1.05)$ & 0.36 & $0(0.51)$ & $-0.20(1.00)$ & 0.70 \\
\hline $\begin{array}{l}\text { BARS: } \\
3 \text { items }(0-3)\end{array}$ & $0.10(0.40)$ & $0.37(0.73)$ & 0.01 & $0.13(0.54)$ & $-0.26(0.70)$ & $0.25^{\star *}$ \\
\hline Blood pressure $(\mathrm{mmHg})$ & $124 / 81(14 / 10)$ & $125 / 79(17 / 11)$ & 0.60 & $\begin{array}{l}1.50(15.48) \\
/-0.76(9.72)\end{array}$ & $\begin{array}{l}-1.89(15.29) \\
/-0.76(9.72)\end{array}$ & 0.37 \\
\hline BMI & $26.6(6.4)$ & $27.3(6.7)$ & 0.66 & $-0.05(1.51)$ & $-0.64(1.45)$ & 0.12 \\
\hline Cholesterol (mg/dl) & $159.8(37.7)$ & $160.0(34.4)$ & 0.99 & $8.8(22.6)$ & $6.4(13.6)$ & 0.63 \\
\hline $\mathrm{HDL}(\mathrm{mg} / \mathrm{dl})$ & $45.4(15.1)$ & $42.4(10.7)$ & 0.34 & $3.5(6.5)$ & $1.2(6.3)$ & 0.19 \\
\hline LDL (mg/dl) & $92.7(33.8)$ & $92.1(31.3)$ & 0.94 & $6.4(19.8)$ & $8.1(20.6)$ & 0.76 \\
\hline Triglyceride (mg/dl) & $104.5(41.4)$ & $111.6(56.7)$ & 0.57 & $-5.7(28.4)$ & $-6.6(38.6)$ & 0.93 \\
\hline Prolactin (ng/ml) & $37.3(62.1)$ & $20.2(14.4)$ & 0.22 & $-13.0(37.5)$ & $2.6(10.0)$ & 0.11 \\
\hline Fasting glucose (mg/dl) & $112.0(25.1)$ & $103.2(32.0)$ & 0.24 & $-4.1(14.8)$ & $-4.2(17.4)$ & 0.98 \\
\hline $\mathrm{HbA} 1 \mathrm{c} \%$ & $4.5(1.5)$ & $5.4(1.5)$ & 0.33 & $-0.1(0.0)$ & $-0.08(0.43)$ & 0.95 \\
\hline
\end{tabular}

-Significance level after Bonferroni correction p < 0.005. "ANCOVA test corrected for differences at TO that were present at T1; BPRS, Brief Psychiatric Rating SCale; SWN-20, Subjective Well-being Under Neuroleptics; WHODAS, World Health Organization Disability Assessment Schedule; SHRS, St. Hans Rating Scale; BARS, Bames Rating Scale for drug-induced akathisia.

\section{Baseline (TO)}

At baseline, no differences were found between the geno-/phenotype and the mean prescribed dose of antipsychotics as shown in Figure 2. In the dose adjustment group the mean DDD was 1.65 (SD 0.83) and in the control group it was 1.92 (SD 0.97) (Ns). PMs, IMs and UMs were prescribed the same amounts of psychopharmacological medication as the EMs.

Second, we found no difference in dose-dependent adverse drug reactions between the normal and extreme metabolizers. Movement disorders were equally distributed in both groups. There were no differences in metabolic parameters. 


\section{Chapter 4}

Third, no differences were found between the normal and extreme metabolizers for psychiatric symptoms, subjective well-being and quality of life. There were no differences in psychiatric symptoms as measured by subscales of the BPRS.

Because only 13 of the patients worked, the four items of the WHODAS 2.0 concerning work were omitted. Patients with a PM genotype or phenotype scored higher on the WHODAS 2.0 than the IMs (PM 41.5, IM 26.6, EM 29.1, UM 34.0) $(p=0.007)$; however, this difference was not significant after Bonferroni correction $(p=0.005)$.

Fourth, no significant differences were found between the dose adjustment and the control group in mean therapeutic drug plasma levels of antipsychotics metabolized by CYP2D6 (analysed with the Mann-Whitney $U$ test). The mean therapeutic plasma levels at T0 of respectively the dose adjustment and the control group were for haloperidol $0.0015 \mathrm{mg} / \mathrm{l}(\mathrm{SD} 0.0013)(\mathrm{n}=4)$ and $0.0023 \mathrm{mg} / \mathrm{l}(\mathrm{SD} 0.0006)(\mathrm{n}=3)$ $(p=0.35)$; risperidone $0.0173 \mathrm{mg} / \mathrm{l}(\mathrm{SD} 0.0164)(\mathrm{n}=9)$ and $0.0073 \mathrm{mg} / \mathrm{l}(\mathrm{SD} 0.0081)$ $(n=3)(p=0.34) ; z u c l o p e n t h i x o l 0.0143 \mathrm{mg} / \mathrm{l}(S D$ 0.0167) $(n=9)$ and $0.0160 \mathrm{mg} / \mathrm{l}(\mathrm{SD}$ $0.0227)(n=2)(p=0.91)$. In the dose adjustment and control group there was a linear incremental relationship between dose and plasma level (data not shown).

Separate analyses were performed with the exclusion of the 12 patients with a PM profile who were selected due to inhibiting medication (data not shown); however, this exclusion had no effect on the results. There were no differences in outcomes between males and females (data not shown). Table 2 shows the individual therapeutic plasma levels of antipsychotics ( $\mathrm{mg} / \mathrm{l})$ metabolized by CYP2D6 of the nine patients in the dose adjustment group who participated in the measurements at T0 and T1. 
Figure 2. Prescribed dose of antipsychotics in DDD per CYP2D6 geno/phenotype group at baseline

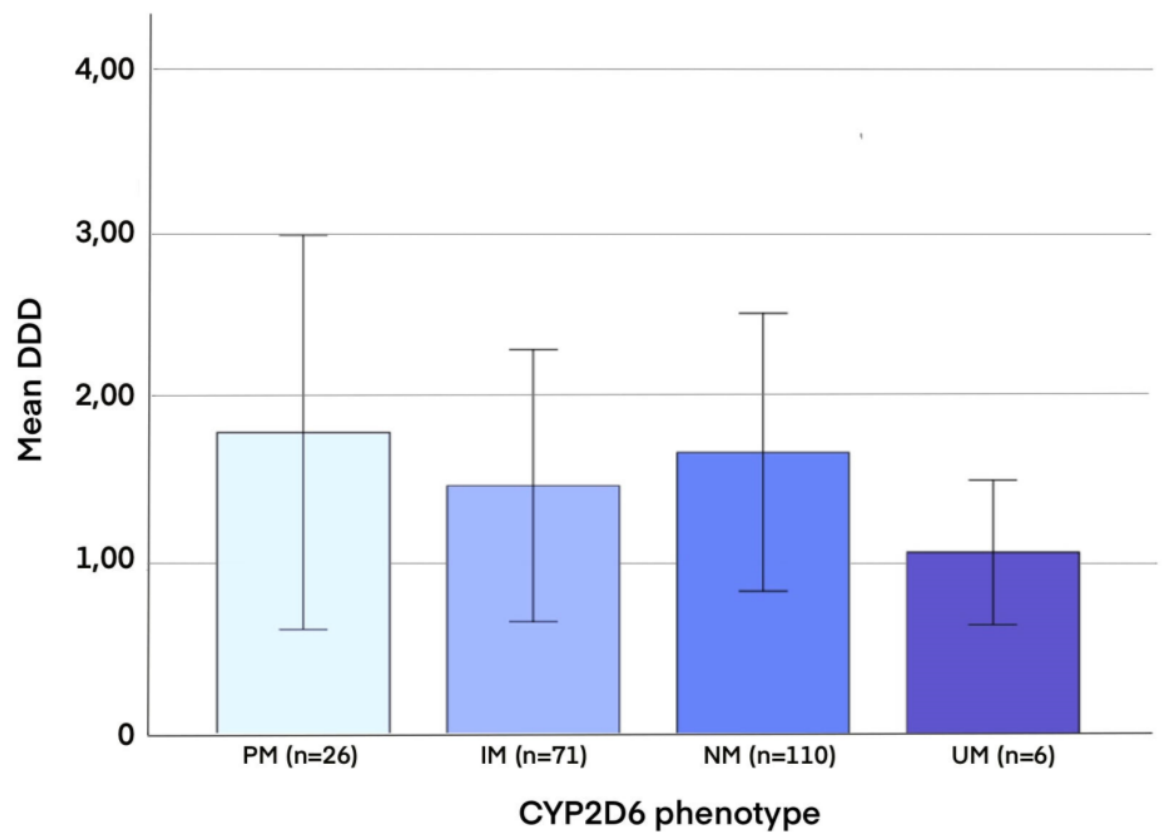

Error bars +/- 1 SD, DDD=defined daily dose, $\mathrm{PM}=$ poor metabolizer,

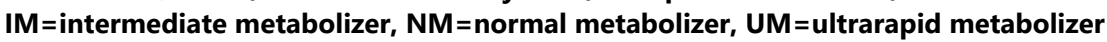

TABLE 2 | Therapeutic plasma levels of antipsychotics (mg/l) metabolized by CYP2D6 of the nine patients in the dose adjustment group measured at T0 and T1.

\begin{tabular}{|c|c|c|c|c|c|c|c|c|c|c|c|}
\hline & \multirow{2}{*}{$\begin{array}{c}\text { Dose } \\
\text { adjustment (\%) }\end{array}$} & \multirow{2}{*}{$\begin{array}{c}\text { Plasma level } \\
\text { change (\%) }\end{array}$} & \multicolumn{3}{|c|}{ TO } & \multicolumn{2}{|r|}{$\mathrm{T} 1$} & \multirow[b]{2}{*}{$\mathbf{z}$} & \multicolumn{3}{|c|}{ T1-T0 } \\
\hline & & & H & $\mathbf{R}$ & $\mathbf{z}$ & H & $\mathbf{R}$ & & H & $\mathbf{R}$ & $\mathbf{z}$ \\
\hline Participant 1 & -25 & & & & 0.0120 & & & Undetectable* & & & \\
\hline Participant 2 & -25 & -54 & & 0.0130 & & & 0.0060 & & & -0.0070 & \\
\hline Participant 3 & -25 & -44 & & & 0.0250 & & & 0.0140 & & & -0.0110 \\
\hline Participant 4 & -25 & & & & Undetectable* & & & 0.0050 & & & \\
\hline Participant 5 & STOP & & & 0.0350 & & & Undetectable* & & & & \\
\hline Participant 6 & STOP & -65 & & 0.0260 & & & 0.0090 & & & -0.0170 & \\
\hline Participant 7 & STOP & 0 & 0.0010 & & & 0.0010 & & & 0.0000 & & \\
\hline Participant 8 & STOP & & & & Undetectable* & & & Undetectable ${ }^{\star}$ & & & \\
\hline Participant 9 & STOP & & & & Undetectable* & & & 0.0110 & & & \\
\hline
\end{tabular}

"All patients were using depot medication and medication adherence was guaranteed, therefore a lab result of $O$ was interpreted as undetectable. $H$, Haloperidol; R, Risperidone; $Z$, Zuclopenthixol; STOP, stopped with inhibiting medication. 


\section{Chapter 4}

\section{Effect of dose adjustment}

No significant effect of dose adjustment was found on psychiatric symptoms, quality of life, or global functioning. Of the 41 patients receiving dose adjustment, six returned to the original dose of the antipsychotics because of deterioration after dose adjustment. Deterioration of psychiatric symptoms resulted in two clinical admissions of outpatients of the dose adjustment group, whereas no admissions were reported in the control group; this difference was not significant.

There was no significant difference in deterioration in psychiatric symptoms between the two groups. In the dose adjustment group, 16 patients (39\%) showed a decline in one of three aspects (defining deterioration) compared with 14 patients (34\%) in the control group. In patients who deteriorated, the mean prescribed dose of antipsychotics (in DDD) after dose adjustment was equivalent to the DDD in patients who remained stable (data not shown). Table 1 shows the mean changes in scores after dose adjustment (T1-T0). There were no differences in outcomes between males and females (data not shown).

Effect of dose adjustment on side-effects and well-being

Dose adjustment did not result in a significant improvement of parkinsonism, dyskinesia, dystonia or akathisia. There was a slight improvement (6\%) in well-being as measured by the SWN-20. However, this is not considered a clinical relevant finding and is not significant after Bonferroni correction.

Effect of dose adjustment on metabolic parameters

Table 1 shows changes in metabolic parameters from baseline until after dose adjustment; no significant differences were found between the two groups. 


\section{Discussion}

This study rejected the hypothesis that patients with SMI on antipsychotic treatment in a clinical setting benefit from dose adjustment based on the CYP2D6 genotype or phenotype. Importantly, at baseline, no differences were found in the severity of side-effects or global/psychiatric functioning between the dose adjustment group (with PM, IM and UM) and control group (with EM). There was no effect of dose adjustment on these parameters.

We expected before we started the study that during years of treatment, clinicians would have optimized dosages to the geno-/phenotype based on side-effects or effectiveness of the drugs used. However, at baseline, the CYP2D6 PMs, IMs and UMs used the same amount of antipsychotics as the EMs. This finding motivated us to find out if dose adjustment could improve the clinical picture. A possible explanation for the absence of an effect, which could also explain the deterioration of some patients, is that long-term use of antipsychotics induces structural brain changes and adaptation of the brain to the changed dopamine levels occurs (132). It is suggested that antipsychotics play a role in the progressive reduction of brain size and enlargement of ventricular spaces in patients with schizophrenia, which is associated with involuntary movement disorders $(200,201)$. Studies show that patients with long-term antipsychotic treatment have a threefold increase in loss of dopamine terminals in the substantia nigra (15\% per decade vs. $5 \%$ in healthy controls) which is suggested to play a role in persistent parkinsonism and tardive dyskinesia (202). Additionally, it is reported that only $3 \%$ of patients discontinuing movement disorder-causing agents, resolved spontaneously from tardive syndromes and a reduction of the dosage of antipsychotics did not decrease the severity of parkinsonism $(66,133)$. It could be that in this clinical population, a dose adjustment to CYP2D6 might have had an effect in an earlier disease stadium but after years of treatment has come too late.

Another possible explanation for these findings is that in both our study groups, the baseline dosage of antipsychotics may have been so high (average DDD 1.65) that D2 receptor occupancy exceeded the optimal window for subjective well-being and to forestall extrapyramidal side-effects $(40,41)$. This could explain why we found no differences in the prevalence of movement disorders and subjective well-being between the dose adjustment group and control group. However, no improvements in extrapyramidal and psychiatric symptoms were found in our patients using lower dosages of antipsychotics (DDD 1.0, after reduction DDD 0.5).

Lastly, the role of the CYP2D6 genotype as a major factor in the metabolization of antipsychotics might be overestimated. The present study supports this hypothesis by showing no differences in plasma levels of drugs in the different phenotypes. 


\section{Chapter 4}

Another clinical study showed, that a proportion of healthy individuals with a PM genotype are phenotypically EMs as measured by CEIBA metabolization (203).

In clinical practice, in patients with $\mathrm{SMI}$, common factors as co-morbidities, inflammation, age, smoking and drug/alcohol use, could cause conversion of genotypic PMs into phenotypic EMs and the other way around (14-19). This undetected phenomenon, named phenoconversion, might explain the negative outcome effects in the present study.

Although a small group of patients $(n=14)$ remained stable with lower dosages of antipsychotics, no patients improved in clinical symptoms. This relatively minor saving in direct costs, did not weigh up to the costs of genotyping a large group of patients $(n=269)$.

\section{Strengths and limitations}

This is the first study which prospectively investigated the clinical utility of dose adjustment to the CYP2D6 genotype or phenotype in patients on antipsychotic medication(6). The representativity was high as we were able to approach all psychiatric patients, with a homogenous African-Caribbean background in a restricted area, i.e. we included all three psychiatric institutes on the island of Curaçao. When including patients, no selection was made regarding the type of psychiatric care, medication, presence of side-effects or treatment response. This has resulted in a heterogeneous group of patients, representative for a general clinical population. It allowed us to analyse the effects of genotyping and dose adjustment in a clinical setting and has led to results with practical clinical value. We have no treatment history of the patients more than 2.5 years before the start of the dose adjustment but we know from clinical practice that patients with SMI make several switches in antipsychotics during the course of their illness and treatment. Earlier studies, in a larger population from this same clinic $(66,204)$ show this is also true for this population.

Although a large cohort of 269 psychiatric patients was genotyped, only a small number of patients (45) had an extreme geno-/phenotype and used medication metabolized by CYP2D6; therefore, a randomized controlled trial design was not possible. A control group was used to investigate differences between normal and extreme metabolizers before dose adjustment and to monitor possible effects from time. Furthermore, the design of the study, with a rater who was blinded to whether a patient was in the dose adjustment group or the control group, reduced possible expectation bias. 
Ideally we would have analysed the effect of dose adjustment in patients using only one type of antipsychotic medication, due to the small numbers of extreme metabolizers this was not possible. Because all the investigated antipsychotics are metabolized by CYP2D6 as reported in the Flockhart table, it is very unlikely that this accounted for the absence of an effect.

At last, the Food and Drugs Administration (FDA) provides a list of strong and weak inhibitors and, by inclusion of patients with a PM/IM phenotype based on interacting medication, greatly improved the prediction of the correct phenotype and has increased the power of the study $(176,189)$. Post hoc power analysis showed that the number of included patients was high enough to demonstrate clinical relevant results. Moreover, not one out of 45 patients showed an evident improvement in side effects, psychiatric symptoms or functioning after dose adjustment and six patients returned to their original doses, due to deterioration of psychiatric symptoms. This supports the conclusion that adjustment of the dose based on the CYP2D6 geno-/ phenotype had no effect.

\section{Author contributions}

Study conception and design: AK, DV, IP, PG, RS, PH, HH

Acquisition of data: AK, DV, PG

Analysis and interpretation of data: AK, DV

Drafting of manuscript: AK

Critical revision: $A K, D V, I P, P G, R S, P H, H H$

\section{Declaration of interest}

None. 


\section{Chapter 4}

\section{Acknowledgments}

The authors thank F.G.M. Heytel MD and G.M. Matroos MD, psychiatrists at the Psychiaters Maatschap Antillen, and staff at the Klinika Capriles and at the psychiatric ward of the local prison (Curaçao) for facilitating recruitment.

\section{Funding}

This study was funded by ZonMW, the Netherlands Organisation for Health Research and Development (Protocol ID 70-72600-98-005). The supporters had no role in the design, analysis, interpretation, or publication of this study.

\section{Data Availability Statement}

Datasets are available on request:

The raw data supporting the conclusions of this manuscript will be made available by the authors, without undue reservation, to any qualified researcher.

\section{Footnotes}

1 Flockhart DA. P450 Drug Interaction Table (Division of Clinical Pharmacology, Indiana University). July 12, 2013. Available at: http://medicine.iupui.edu/clinpharm/ddis/main-table/. Accessed 2013.

${ }^{2}$ Central Bureau of Statistics Curaçao. Available at: http://www.cbs.cw. Accessed 2017.

${ }^{3}$ Switching antipsychotics available at: http://wiki.psychiatrienet.nl/index.php/SwitchAntipsychotics Accessed 2014 


\section{CHAPTER 5}

Proxy WHO Disability Assessment Schedule 2.0 is clinically useful for assessing psychosocial functioning in severe mental illness

Anne B. Koopmans

Daphne van Hoeken

Diana E. Clarke

David J. Vinkers

Peter N. van Harten

Hans W. Hoek

Front Psychiatry (2020) 11 (April) :1-8. doi:10.3389/fpsyt.2020.00303 


\section{Chapter 5}

\section{Abstract}

Aims: This study explores how well the World Health Organization Disability Assessment Schedule (WHODAS 2.0) assesses problems with psychosocial functioning in patients with severe mental illness (SMI). Further, we assessed the relationships between psychosocial functioning and psychopathology, medication side effects, treatment setting, and quality of life.

Methods: We performed an observational, cross-sectional study on the island of Curaçao to assess psychosocial functioning in 77 patients with SMI; they mainly had psychotic disorders. We interviewed their healthcare providers using the proxy version of the WHODAS 2.0. In addition, patients were examined for psychiatric symptoms, medication side effects (including drug-induced movement disorders), and quality of life. Associations were examined with Spearman's rank correlation ( $\rho$ ).

Results: Difficulties in psychosocial functioning were reported by patients with SMI in the WHODAS 2.0 domains of Understanding and communicating (Mean $(M)=34.5$, standard deviation $(S D)=18.6)$, Participation in society $(M=25.5, S D=15.6)$, and Getting along with people $(M=24.1, S D=16.1)$. Notably, outpatients had more problems participating in society than inpatients $(M=33.6, S D=18.5$ versus $M=23.2$, $S D=14.1, p=0.03)$. A positive correlation was observed between drug-induced parkinsonism and the WHODAS 2.0 total score $(\rho=0.30 ; p=0.02)$, as well as with various subscales, getting around and household activities.

Conclusion: The proxy version of the WHODAS 2.0 is clinically useful for patients with severe mental illness. The highest scores on the WHODAS 2.0 were found in domains related to interactions with other people and to participation in society. Inpatient status appeared to aid participation in society; this might be due to living in the sheltered clinic environment and its associated daily activities. We further found that drug-induced parkinsonism was associated with a broad spectrum of psychosocial disabilities. 


\section{Introduction}

The term 'Severe Mental IIIness' (SMI) was introduced by the USA Substance Abuse and Mental Health Services Administration to differentiate between psychiatric patients with and without problems in daily functioning. Criteria for SMI include excessive disturbance and clinically significant distress or impairment in social, occupational or other important areas of functioning. Although, potentially, all DSM5 diagnoses can be involved,

most of the patients who qualify as severely mentally ill have been diagnosed with schizophrenia, or another psychotic or major mood disorder. The prevalence of SMI in the USA is about $5 \%$ in adults (73).

In the aim of treatment of patients with SMI, there is currently a shift in focus from care to recovery. Recovery is a process in which the most important goal is to regain a meaningful life in the community, including participation in valued activities and fulfillment of social roles (205-208). Participation in everyday activities, such as occupational or educational activities, coupled with adequate social functioning, are considered important indicators of recovery $(206,209)$. Central to the monitoring of the recovery process is the measurement of patients' psychosocial functioning.

In DSM-5, the World Health Organization Disability Assessment Schedule (WHODAS 2.0) was introduced as a better measure of psychosocial functioning in individuals with psychiatric disorders (210) than the earlier Global Assessment of Functioning (GAF). The WHODAS 2.0 was explicitly designed to exclude items on pathology to avoid confounding symptoms and functioning, which is a core problem with the GAF (211).

Impaired psychosocial functioning in patients with SMI is multifactorial: adverse medication reactions (parkinsonism, obesity), and treatment setting (in- or outpatient) may influence functional recovery (1,186,212-214). For example, the medication side effect parkinsonism is associated with poor vocational performance (212)' while some studies show positive results for community-based rehabilitation versus in-hospital treatment in patients with SMI (213-215).

The WHODAS 2.0 offered valuable insight into patients' experiences, had acceptable validity and psychometric properties, but it was challenging to use with patients with long-term psychotic disorders and several limitations were reported (74,76), e.g., caregivers generally reported worse functioning than patients themselves. A lack of insight (i.e., awareness of their illness and its consequences) in patients with SMI meant they registered fewer difficulties than expected in the questionnaire (74-76). Researchers also had to try hard to keep such patients focused on answering the questions, possibly because they had cognitive deficits (76). Using the proxy version of the WHODAS 2.0 could parry these limitations, since the interview is done with 


\section{Chapter 5}

the patient's healthcare professional or a family member. Yet, to our knowledge, there are only a few publications about using it for patients with severe (neuro)psychiatric disorders $(75,216,217)$. One study, in Ethiopia in patients with SMI, found that the proxy version had acceptable validity and psychometric properties, but higher mean values and better responsiveness to change than the patient interview version (75).

Our study explored the use of the proxy version of the WHODAS 2.0 for assessing psychosocial functioning in a population with SMI. Further, we assessed the relationships between functioning and psychopathology, medication side effects, treatment setting, and quality of life.

\section{Methods}

Our study was performed in the well-defined geographical area of Curaçao, an island in the Caribbean and part of the former Dutch Antilles. The study was also part of a clinical trial on CYP2D6 and CYP2C19 genotyping in patients with SMI (88) Our study population of 77 patients with SMI was part of the Curaçao Extrapyramidal Syndromes studies cohort (I-XIII) $(8,66)$. AK, DV, PH and HH have worked as medical doctors on Curaçao.

Our participants were inpatients recruited in November-December 2014 from the Klinika Capriles (the only psychiatric hospital on the island) and from the psychiatric ward of the prison, and outpatients recruited from the psychiatric outpatient clinic (Psychiaters Maatschap Antillen).

Inclusion criteria for the study were: (1) Antillean ethnicity, defined according to the Dutch Central Bureau of Statistics as born on the former Netherlands Antilles, with at least one parent also born on the former Netherlands Antilles; (2) aged 18 years or older, and (3) meeting SMI criteria, defined as having a mental disorder causing functional impairment as shown by the need for intensive psychiatric care in or out of hospital. Exclusion criteria were: (1) refusal to give written informed consent, or (2) no family member or healthcare professional available and willing to participate in the study.

We approached 86 patients, of whom 77 (90\%; 30 females, 47 males) met our inclusion criteria. Eight patients were excluded because they had no healthcare professional or family member available for interview; one patient died before inclusion. After being informed about the study procedures, all patients signed an informed consent form. 
Of the 77 proxy questionnaires, two were completed by family members and 75 by healthcare professionals. The healthcare professionals were all nurses, with patient contact at least once a week.

\section{Measurements}

Each patient had a thorough assessment of psychopathology, subjective experience, extrapyramidal symptoms, quality of life, and global functioning. Demographic information was registered. In line with a previous study on SMI patients on Curaçao (8), in this study we used the diagnosis registered by the treating psychiatrist. The healthcare system on Curaçao meets Western standards and the majority of medical specialists are trained in the Netherlands. Information on psychiatric and somatic medication was derived from the electronic patient file. Until recently, Dutch was the only official language on Curaçao and we were able to communicate in Dutch with all healthcare professionals and family members. However, not all our study participants had completed secondary school education, and for those who did not understand Dutch (32 out of 77 patients), we communicated in the local language, Papiamentu, with the help of a bilingual hospital resident-in-psychiatry. To prevent outcome effects because of inter-rater variability, all measurements were done by the same investigator (AK). To prevent halo effects, the nurses were interviewed for the WHODAS with the interviewer blinded to the patient concerned. In this way we could ensure that there was no clinical prejudice in the way the interviewer scored the WHODAS items.

\section{Functioning}

Functioning was measured using the official Dutch translation of the proxy interview version of the WHODAS 2.0 (32 items), which was used with well-informed healthcare professionals or family members (218). Ideally we would also have used the patient version of the WHODAS 2.0 to provide information on the relationship between the two versions of the scale. This information would have helped to strengthen the rationale to use the proxy version of the scale. Previous studies have reported that patients with schizophrenia and schizoaffective disorders are poor raters of their level of functioning but good raters of other characteristics such as quality of life (219221). Higher levels of depressive symptoms are associated with underestimations in self-reports, while delusions and suspiciousness are associated with overestimation of functioning compared to interviewer judgments $(222,223)$. In addition, co-authors $\mathrm{DH}$ and HH cooperated in the World Health Organization's (WHO) development of the WHODAS 2.0 and concluded that the patient version was difficult to administer to patients with schizophrenia (224). Also, in a small pilot study, first author AK tested 


\section{Chapter 5}

this questionnaire. She found that concentration problems hampered the completion of the WHODAS 2.0 questionnaire, possibly due to its length (36 items) and the complex wording of some of the items. These concentration problems negatively affected the reliability of the answers and prompted our use of the informant version. Furthermore, almost none of the patients in the pilot and current study had completed secondary school, which may also explain the difficulties observed in the pilot patients when completing the WHODAS 2.0. Their low level of education may have resulted in problems in answering the complex questions. These observations supported our use of the informant version.

The questionnaire measures patients' functioning in six domains: (1) understanding and communicating (6 items), (2) getting around (5 items), (3) self-care (4 items), (4) getting along with people (5 items), (5) work and household activities (each 4 items), and (6) participation in society (8 items). Four items on work were not included in our study because almost none of the participants had a job - this is in line with the instructions in the Manual for WHO Disability Assessment Schedule WHODAS 2.0 (225).

Standardized summary scores range from $0-100$, with higher scores indicating greater levels of disability in functioning (225).

The patient interview version of WHODAS has a robust factor structure that is replicated across countries and populations, has high internal consistency (Cronbach's $\alpha$ coefficient of 0.96 for its 36 items, good test-retest reliability (intraclass correlation coefficient of 0.98 ), good concurrent validity with other quality of life and handicap scales (correlation coefficients $0.45-0.65$ ), and a reasonable sensitivity to change (effect sizes $0.44-1.38)(196,226)$. In the general population $90 \%$ has a total score of 35 or lower, indicating little or no disability in functioning (225). The proxy interview version shows good internal consistency (0.82-0.99) and good convergent validity in patients with severe mental disorders (75). It has a moderate sensitivity to change (0.14-0.57), which is nonetheless more sensitive than the patient version in this specific (SMI) population (0.17-0.35) (75).

The interviewer, a resident-in-psychiatry (AK), was trained by experts $(\mathrm{DH}$ and $\mathrm{HH})$ in scoring the WHODAS 2.0.

\section{Symptom severity and side effects}

The severity of patients' psychopathology was assessed with the Brief Psychiatric Rating Scale (BPRS; 24 items). This rating scale has five subscales: Affect (anxiety, guilt, depression, somatic); Positive Symptoms (thought content, conceptual disorganization, hallucinatory behavior, grandiosity); Negative Symptoms (blunted 
affect, emotional withdrawal, motor retardation); Resistance (hostility, uncooperativeness, suspiciousness); and Activation (excitement, tension, mannerisms-posturing) $(191,227,228)$. Extrapyramidal side effects were assessed with the St. Hans Rating Scale (SHRS), a multidimensional rating scale for the evaluation of dyskinesia (18 items), parkinsonism (10 items), and dystonia (2 items) induced by antipsychotics. The dyskinesia is scored in two situations: in passive and active circumstances (192). Akathisia, a movement disorder and medication side effect, was measured using the Barnes Akathisia Rating Scale for drug-induced akathisia (BARS; 3 items) $(193,194)$.

For all the above scales, higher scores indicate more severe symptoms. AK, a resident-in-psychiatry, was the interviewer for all the scales; she was trained by experts in scoring the SHRS and BARS (PH and $\mathrm{HH})$, and this included a training course with 10 Antillean patients with SMI on Curaçao.

Patient experience of psychopharmacological medication side effects was measured with the Subjective Well-Being Under Neuroleptics Scale (SWN-20; 20 items). This is a self-rating scale that assesses subjective experience over the preceding seven days (198). For patients who were unable to read Dutch, the SWN-20 questions were translated into Papiamentu. Scores of negative statements were recoded to indicate that higher scores on all statements reflected higher levels of well-being. Druginduced weight gain was measured using Body Mass Index (BMI).

\section{Quality of life}

Quality of life was assessed with the EQol 5D (EQ-5D; 5 items), a widely-used scale that measures health status on five dimensions: (1) mobility, (2) self-care, (3) daily activities, (4) pain/discomfort, and (5) anxiety/depression (195,229). Higher scores indicate a lower quality of life. The EQ-5D shows some overlap with several WHODAS 2.0 domains, including getting around, self-care, and work and household activities.

\section{Statistics}

All analyses were performed with IBM SPSS Statistics Version 25. Normality of the data distribution for all measurements was assessed by inspecting Q-Q plots. We conducted multiple regression analyses to identify how much age and gender contributed independently to the WHODAS 2.0 outcomes. The Mann-Whitney $U$ test was used to compare outcomes between in- and outpatients. Correlations between the WHODAS 2.0 and the other measures were examined using Spearman's rank correlation $(\rho)$, with the significance level set at $p<0.05$. 


\section{Chapter 5}

\section{Results}

\section{Patient characteristics}

Eighteen (23.4\%) patients were outpatients and 59 (76.6\%) were inpatients. The inpatients lived in housing on the clinic site and had been there for at least 2.5 years. Of those included in the study, $95 \%$ had a diagnosis of a psychotic disorder. Other diagnoses included depression, bipolar disorder, substance abuse, and intellectual disability. All patients were using antipsychotic medication (of these, 40 (52\%) used biperidene and 45 (58\%) were prescribed two types of antipsychotics). Antidepressant medication was prescribed for 7 (9\%) of the patients, while $8(10 \%)$ were using anti-epileptic medication and 33 (42\%) were using cardiovascular medication.

\section{Distribution of total and domain scores of functioning}

The WHODAS 2.0 mean standardized domain and total scores are shown in Table 1. The mean total score of the 32-item WHODAS 2.0 scale was $31.2(S D=16.5)$ with a minimum score of 2.5 and a maximum score of 78.9. Twenty percent of patients had a total score $\geq 35$, which falls above the $90^{\text {th }}$ percentile of overall disability in functioning according to general population data for the WHODAS 2.0 interview version (225).

Multiple regression analyses showed no difference in the distribution of WHODAS 2.0 scores according to age or gender.

Re-analysis of the outcomes, excluding the two questionnaires filled out by family members, did not change the results.

\begin{tabular}{|c|c|c|c|c|c|c|c|c|c|c|c|}
\hline \multirow[t]{2}{*}{ Measurements } & \multicolumn{3}{|c|}{ Total } & \multicolumn{3}{|c|}{ Inpatients } & \multicolumn{3}{|c|}{ Outpatients } & \multicolumn{2}{|c|}{ Mann Whitney-U } \\
\hline & $\mathrm{N}$ & Mean & SD & $\mathrm{N}$ & Mean & SD & $\mathrm{N}$ & Mean & SD & $\mathbf{u}$ & p-value \\
\hline Age in years & & 51.4 & 11.4 & & 52.4 & & & 48.2 & & 404.5 & .128 \\
\hline Female (\%) & & 38.9 & & & 39.0 & & & 38.9 & & & $.994^{\prime \prime}$ \\
\hline \multicolumn{12}{|l|}{ WHODAS 2.0 domains } \\
\hline Understanding and communicating & 77 & 34.5 & 18.6 & 59 & 35.3 & 18.0 & 18 & 31.9 & 20.8 & 470 & .46 \\
\hline Getting around & 77 & 14.1 & 18.6 & 59 & 13.2 & 18.1 & 18 & 17.0 & 20.4 & 465 & .41 \\
\hline Self-care & 77 & 9.0 & 11.1 & 59 & 8.9 & 11.5 & 18 & 9.0 & 10.1 & 510 & .79 \\
\hline Getting along with people & 69 & 24.1 & 16.1 & 55 & 23.4 & 16.2 & 14 & 26.8 & 16.2 & 327.5 & .39 \\
\hline Household activities & 75 & 18.5 & 21.0 & 59 & 17.1 & 20.6 & 16 & 23.8 & 22.4 & 389.5 & .27 \\
\hline Participation in society & 74 & 25.5 & 15.6 & 58 & 23.2 & 14.1 & 16 & 33.6 & 18.5 & 292.5 & $.02^{*}$ \\
\hline Total score ${ }^{\dagger}$ & 66 & 31.2 & 16.5 & 54 & 29.6 & 15.5 & 12 & 38.3 & 19.6 & 223.0 & .09 \\
\hline
\end{tabular}


Functioning and psychopathology

The correlations between psychopathological symptoms as measured by the BPRS and WHODAS 2.0 scores are shown in Table 2.

\begin{tabular}{lcccccc} 
TABLE 2 I Correlations (Spearman mo) between scores on WHO Disability Assessment Schedule (WHODAS) 2.0 and other measures in patients with severe mental illness. \\
\hline
\end{tabular}

SMI, severe mental illiness; WHODAS, World Health Organization Disability Assessment Schedule; BPRS, Brief Psychiatric Rating Scale; SHRS, St. Hans Rating Scale; BARS, Bames Akathisia Rating Scale for drug-induced akathisia; EQ-5D, EQol 5-D; SWN-20, Subjective Well-Being Under Neuroleptics Scale; BMI, body mass index, 'standardized total score of the 32 item scale (exclusion of work items), " significant at.05 level, " significant at.01 level

Functioning and medication side effects

The correlations between SHRS, BARS, SWN-20, and BMI scores with WHODAS 2.0 scores are shown in Table 2. The results indicate that a higher level of drug-induced parkinsonism was associated with more problems in functioning in the areas understanding and communicating, getting around and household activities.

Higher well-being under neuroleptics is associated with better functioning in the domain of understanding and communicating.

Functioning and quality of life

The correlations between the EQ-5D and WHODAS 2.0 scores are shown in Table 2. A higher WHODAS 2.0 score (worse global functioning) is associated with a higher EQ-5D score (lower quality of life). 


\section{Chapter 5}

\section{Discussion}

This study is one of the first to examine WHODAS 2.0 proxy scores of psychosocial functioning in patients with SMI. Our results show that symptom severity and medication side effects have a negative association with functioning, quality of life, and subjective well-being in patients with SMI. They also recorded the highest scores on WHODAS 2.0 domains related to interactions with other people and participating in society, revealing their greater psychosocial disabilities in these areas. These results are consistent with earlier findings, in which psychotic patients reported problems with community activities and experienced barriers in their environment (76).

\section{Psychopathology}

The correlation between psychopathology symptoms and participation in society confirms earlier findings in SMI populations, in which patients with more severe psychopathology reported more difficulties in functioning on the WHODAS 2.0 (12and 36-item versions), whereas patients with fewer mental health problems reported better scores for recovery $(75,216,230)$. We did not find a significant correlation between psychosocial functioning and positive symptoms; this is in agreement with an earlier study in patients with schizophrenia, which found no relationship between positive symptoms and social network size (231). It suggests that the primary focus of traditional treatment on symptoms like hallucinations and thought disorders is not necessarily associated with better functioning.

\section{Treatment setting}

In contrast to our expectations, outpatients reported more problems with participation in society than inpatients. This contrasts with results from a previous validation study of patients with schizophrenia, in which outpatients demonstrated better social functioning than inpatients, as rated by independent assessors (232). There are several possible explanations: first, inpatients may have better participatory skills than outpatients. This seems unlikely however, because their psychopathology symptoms did not differ. Another explanation stems from healthcare professionals perhaps having different frames of reference for in- and outpatients and their participation in society. For outpatients they may have other insights into barriers for functioning (e.g. stigmatization) in society. It is possible that long- and short-term inpatients and their healthcare professionals are accustomed to the status quo and have lower expectations of life than outpatients (and their healthcare professionals) 
who are constantly confronted with their disabilities when trying to operate in society.

The third, and in our opinion the most plausible, explanation is that participation is easier in the sheltered environment of an inpatient setting, in which co-citizens also have severe mental disorders, and where social activities are organized, patients are encouraged to participate in activities, basic life needs are taken care of, and barriers and problems are partly resolved by caregivers.

\section{Medication side effects}

There was a significant correlation between drug-induced parkinsonism and problems in getting around and performing household activities. This could be related to the symptoms of drug-induced parkinsonism such as tremor, bradykinesia, rigidity and postural instability (233). These motor symptoms can directly influence walking pattern and daily household tasks $(234,235)$. In addition, there was a significant correlation between parkinsonism and understanding and communicating. This is in line with earlier reports about the non-motor signs of druginduced parkinsonism e.g. cognitive dysfunction, apathy and mood disorders (236238). Hence, drug-induced parkinsonism appears to be associated with a broad spectrum of dysfunction and may be a barrier to recovery.

\section{Strengths and limitations}

We studied a difficult-to-examine population of severely ill psychiatric patients who were recruited from all three psychiatric institutions on Curaçao. There was no selection regarding the type of psychiatric care or medication, presence of side effects, or treatment response when the participants were recruited. This resulted in a group of patients who are representative of the general population with SMI on Curaçao. Although nearly half of our participants were unable to communicate in Dutch, we were able to use the official Dutch translation of the WHODAS 2.0, as all the healthcare professionals are educated in Dutch. So far, no local-language versions of the WHODAS 2.0 are available for populations in the Caribbean who do not speak English or Dutch. Although it would have been valuable to interview a relative, most of the patients did not have an engaged relative. A personal healthcare provider who was engaged with all the patient's personal activities was interviewed instead. In a previous study assessing patient functioning, it was found that highcontact clinicians generated ratings of everyday functioning that were more closely linked to patients' ability scores than those from friends or relatives (239). 


\section{Chapter 5}

Not all patients were able to read the Dutch language. To be able to administer the SWN-20 self-report questionnaire to these patients, it was translated by a bilingual (Papiamentu-Dutch) resident-in-psychiatry. No back translation was performed and we did not formally ensure whether the validity and reliability of the questionnaire were still intact. Failure to complete back translation of the SWN-20 might have affected the reliability and validity of the data from the questionnaire and its subsequent correlation with the WHODAS 2.0 and its domains. Our examination of the correlation between the WHODAS 2.0 and its domains and the SWN-20 in the subset of patients who completed the Dutch version of the scale $(n=38)$ showed similar results to those on the subset that completed the translated version of the SWN-20 $(n=39)$. This indicates that the negative impact of the failure to back translate was minimal.

Problems with using questionnaires on functioning with patients with poor insight and cognitive deficits, as reported in earlier studies and confirmed in a pilot study, were parried by using the proxy-version with well-informed third parties. A limitation of this study is that we did not interview the patients themselves using the WHODAS 2.0, because a pilot study with the patient version of the questionnaire showed that patients' concentration problems negatively affected the reliability of their answers. Therefore we could not compare the information given by patients with that from their proxies.

Responder bias (judgment differences between healthcare professionals attending inpatients vs. outpatients) could not be ruled out, however, the results indicate that useful information on psychosocial functioning can be retrieved from proxies.

Lastly, both the small sample size and the non-normal distribution of our data, requiring non-parametric tests, are challenges for the power of our analyses, and thus the strength of our findings. Non-parametric tests (here: Spearman rho and Mann Whitney) have less statistical power than their parametrical equivalents. As our main purpose was to explore relationships between different measures, we chose to show all individual results of our small sample size study. Thus, together with the fact that the study has a cross-sectional design, the results need to be treated with caution. Future studies, using larger sample sizes are needed to confirm our findings.

\section{Conclusions}

In this exploratory study, we show that the proxy version of the WHODAS 2.0 is a clinically useful instrument for patients with severe mental illness and that it provides good insight into the psychosocial functioning of these patients. In patients with lack of insight into their disease or severe cognitive deficits, this proxy questionnaire version can be used to determine useful information about patients' problems in 
psychosocial functioning. The highest scores on the WHODAS 2.0 (i.e., indicating the greatest difficulties in functioning) were found in domains related to interactions with other people and participation in society. Inpatients were reported to experience fewer problems with participation in society than outpatients, which could be due to the adapted circumstances and sheltered environment of the clinic. We found druginduced parkinsonism is associated with a broad spectrum of social disabilities. Before any practice or policy recommendations can be made, our results need to be replicated, preferably with larger samples. Wherever possible, researchers should include the patient interview version of the WHODAS 2.0 in order to compare the outcomes of the two versions of the questionnaire.

\section{Conflict of Interest Statement}

The authors declare they have no personal, financial or professional conflict of interests.

\section{Author Contributions Statement}

Study conception and design: AK, DV, DH, DC, $\mathrm{PH}, \mathrm{HH}$

Acquisition of data: AK

Analysis and interpretation of data: AK, DV, DC, DH

Drafting of manuscript: AK

Critical revision: $\mathrm{AK}, \mathrm{DC}, \mathrm{DH}, \mathrm{DV}, \mathrm{PH}, \mathrm{HH}$

All authors read and approved the manuscript.

\section{Funding}

This study was funded by the Netherlands Organization for Health Research and Development (ZonMW, Protocol ID 70-72600-98-005). ZonMW provided financial support only and had no role in the analysis or interpretation of the data, nor in the preparation, review, or approval of the manuscript. 


\section{Chapter 5}

\section{Acknowledgments}

We thank F.G.M. Heytel, MD, and G.M. Matroos, MD, psychiatrists at the Psychiaters Maatschap Antillen, and the staff at the Klinika Capriles and the psychiatric ward of the local prison on Curaçao for facilitating recruitment. We also thank S.G. Smith, PhD, science writer, and J.L. Senior for editing the manuscript; Mathijs Deen, statistician, for assisting with the statistics, and Igmar Poulina, MD, for translating the Subjective Well-Being Under Neuroleptics (SWN-20) into Papiamentu.

\section{Contribution to the Field Statement}

For years, the focus of treatment in psychiatric patients with severe psychiatric disorders has been symptom-oriented. But more recently the aim of treatment has been focusing on recovery, in which the most important goal is to regain a meaningful life in the community. Central to the monitoring of the recovery process is the measurement of psychosocial functioning, for which DSM-5 recommends the use of the WHODAS 2.0. This instrument has been shown to give valuable insight into patients' experiences, but it is difficult to use with patients with long-term psychotic disorders because of their lack of insight (i.e., awareness of their illness and its consequences) and cognitive deficits. We show that the proxy version of the WHODAS 2.0 can parry these limitations and that it is a clinically useful instrument to measure psychosocial functioning in patients with severe mental illness. In our study population, the highest scores on the WHODAS 2.0 were found in domains related to interactions with other people and to participation in society. Inpatients appeared to have fewer problems with participation in society; this could be due to their living in a sheltered clinical environment and the associated daily activities. We further found that drug-induced parkinsonism was associated with a broad spectrum of psychosocial disabilities. 


\section{Declarations}

Ethics approval and consent to participate

The study protocol was approved by the Institutional Review Board of Maastricht University, the Netherlands. The procedures were in accordance with the ethical standards of the Helsinki Declaration of 1975 (as revised in 1983). All patients signed written informed consent forms after being informed about the study procedures. The study was registered in an international trial registry at http://www.clinicaltrials.gov (NCT02713672).

\section{Availability of data and materials}

The raw data supporting the conclusions of this manuscript will be made available by the authors, without undue reservation, to any qualified researcher 



\section{CHAPTER 6}

Summary of main findings and general discussion 



\section{Summary of main findings}

In chapter 1 we introduced CYP enzymes. The effect of most medication is determined by the rate at which it is metabolized by CYP enzymes in the liver.

In psychiatry, CYP2D6 and CYP2C19 are the most important enzymes. A combination of functional and non-functional alleles is responsible for the activity of these enzymes. There are four phenotype groups: poor (PM), intermediate (IM), normal (NM) (previously referred to as 'extensive'), and ultrarapid metabolizers (UM), which are used to predict whether and how well a drug is metabolized. In this thesis, I have attempted to bridge the outcomes of pharmacogenetic studies with psychiatric clinical practice. The aims and outlines of the different studies in this thesis were described and explained.

In chapter 2 we reviewed the literature about the prevalence of CYP2D6 and CYP2C19 in different ethnicities worldwide. We translated the predicted phenotypes into a probability estimate of having a non-normal metabolizer status, defined by the prevalence of $P M+I M+U M$ in percentages. The mean probability estimates worldwide are $36.4 \%$ for CYP2D6 and $61.9 \%$ for CYP2C19, with a very large geographical variation (min-max $2.7-61.2 \%$ for CYP2D6 and $31.7-80.1 \%$ for CYP2C19). This means that more than half of the world population has a non-normal CYP2D6 and/or CYP2C19 metabolizer phenotype. The world maps show the geographical regions and countries for which information is available, but also highlight the regions with little or no information, especially in Africa and the Middle East.

In chapter 3 we assessed the prevalence of CYP2D6 and CYP2C19 genotypes in psychiatric patients and in the general population of Dutch Caribbean origin. Arawak's were the native inhabitants of Curaçao. In 1499, Spanish Europeans colonized the island and brought in slaves from West Africa. Immigrants from Latin America and other Caribbean islands came in after slavery was abolished and admixed with the local inhabitants (179). We investigated the impact of this admixture of ancestors on their allele composition and we analyzed if there were differences between psychiatric patients and the general population. In total, 435 individuals were genotyped for CYP2D6 and CYP2C19. No differences in the prevalence of alleles was found between the general population and psychiatric patients. The prevalence of CYP2D6 predicted phenotypes is PM $=5 \%, \mathrm{IM}=32 \%$, $\mathrm{NM}=61 \%$ and $\mathrm{UM}=2 \%$, and of CYP2C19 predicted phenotypes $\mathrm{PM}=2 \%, \mathrm{IM}=$ $27 \%, N M=40 \%$ and $\mathrm{UM}=31 \%$. This distribution is in fact very similar to that seen in Europeans (188).

In chapter 4 we tested the hypothesis that dose adjustment to the CYP2D6 phenotype in patients with severe mental illness (SMI) can reduce side effects and improve treatment outcomes in slow metabolizers. If this is true, we would expect 


\section{Chapter 6}

better psychosocial functioning and an increase in quality of life. Of the 269 patients with SMI who were genotyped, we selected all those with a non-normal metabolizer profile and using psychiatric medication metabolized by CYP2D6 $(n=45) ; 12$ of the 45 patients were defined as PMs because they were on CYP2D6 inhibiting medication. We compared them with 45 patients with a normal metabolizer profile. Four months after dose adjustments, patients were examined on the same parameters. Not one of the patients of the dose adjustment group improved in symptoms, side effects, global functioning or quality of life. Six patients deteriorated of whom two patients had to be admitted to the psychiatric hospital because of psychotic decompensation. High maintenance doses, irreversibility of side effects and adaptation of the brain to the changed dopamine levels, are possible explanations for the absence of an effect.

In chapter 5 we administered the WHODAS 2.0 proxy-administered version in 77 caregivers of patients with SMI so that we could investigate its relationship with psychiatric symptoms, place of treatment, and side effects. The highest scores on the WHODAS 2.0 are found in domains related to interactions with other people and participation in society. Contrary to our expectations, inpatient status appeared to protect patients in their participation/activities in society. This could be because the sheltered environment of a clinic and the associated adjustments in daily activities makes participating in the local society easier.

In patients with a lack of disease insight or severe cognitive deficits, this proxy version of the questionnaire proved useful in gaining more information about their psychosocial disability. 


\section{Discussion}

After the introduction of antipsychotics and antidepressants in the 1950s, the effectivity of these drugs was demonstrated in numerous double-blind controlled trials $(240,241)$. However, antipsychotics and antidepressants produce several side effects, especially in patients with severe mental illness, who are prescribed these drugs for years and who often have severe side effects. Because there is a wide variability in individual response to standard doses of these drugs, finding the right drug type and dose is a challenging task for the clinician and can take months or even years (6). Pharmacogenetic testing of individual patients for CYP2D6 and CYP2C19 (referred to here as CYP genotyping) could offer more insight into the optimal drug type and dose they require for a good treatment response.

Currently, therapeutic drugs monitoring (TDM) is used to analyze if a dose prescription results in the desired serum level in the blood. It can be argued that genotyping is superior to TDM because it gives a life-long insight into metabolization of medication. However, other factors that can also influence serum levels, are not assessed with genotyping.

So far there has been no conclusive evidence that CYP genotyping is beneficial for clinical outcomes. Pharmacokinetic studies have shown the influence of the CYP2D6 enzyme on serum levels of medication $(23,242,243)$, while relationships between clinical parameters and CYP2D6 activity have also been investigated $(21,244,245)$. Based on these studies, pharmacogenetic guidelines now advise adjusting the dose or changing the medication to fit the phenotype $(44,139,246)$. However there is only scarce evidence to show improvement in clinical outcomes after genotyping $(6,27,87)$. There is, therefore, an urgent need for conclusive advice on using CYP genotyping in psychiatry. In this thesis, we have tried to bridge the gap between the evidence from pharmacogenetic studies and clinical psychiatric practice. We have shown there is a huge variation in phenotypes in different ethnicities, which might explain differences in patients' response to medication. We found, however, no evidence for the clinical relevance of CYP genotyping in patients with severe mental illness (SMI). We conclude that it is still too early to start routine genotyping in this patient population. 


\title{
Chapter 6
}

\section{CYP genotyping and clinicians}

\author{
"What do I have to do with this?!"
}

This was the reply from a general practitioner (GP) on receiving the laboratory result with a patient's CYP2D6 and CYP2C19 profile. When we correctly informed pharmacies and GPs about their patients' phenotype (92), it became clear that not all GPs were able to use this information. We informed 132 GPs about their patients' phenotype and after one year we asked if they had adjusted treatment to the phenotype. Only 4 (3\%) responded and they had not used the information. This is in line with a 2017 study in the Netherlands that found genotyping results were available to GPs for only $3.1 \%$ of the genotyped patients and at pharmacies for $5.9 \%$ of their patients (92). In 2014, few psychiatrists were ordering a pharmacogenetic test (91). However, one study on patients with schizophrenia found positive effects of genotyping on their physician's opinion regarding the patient's clinical status (although there was no evidence of improvement of side effects) (89). In 2018 the FDA cautioned that there may be a lack of clinical evidence supporting the utility of clinical pharmacogenetic testing. Although this statement was not agreed on by professionals investigating CYP genotyping in clinical practice (247).

At the start of this PhD project in 2014, it seemed that CYP genotyping was not being adopted in standard psychiatric care and was dependent on the individual preference of the clinician. Until now routine pharmacogenetic testing has not been translated into psychiatric practice $(248,249)$.

\section{Prevalences of CYP2D6 and CYP2C19 worldwide}

A review of the literature in 2019 showed that a large percentage of the world population does not has a normal metabolizer phenotype. In chapter 2 we introduced the concept of a probability estimate for having a non-normal phenotype, as defined by the total prevalence of $\mathrm{PM}+\mathrm{IM}+\mathrm{UM}$. Worldwide, the probability estimates of non-normal metabolizers are 36.4\% for CYP2D6 and $61.9 \%$ for CYP2C19. There is also a large geographical variation in the prevalences of CYP2D6 (2.7-61.2\%) and CYP2C19 (31.7-80.1\%). The Mozabite people in Algeria, for example, have a $61 \%$ chance of having a non-normal metabolizer phenotype; it is therefore not appropriate to start with them on the same dose of an antipsychotic or antidepressant as a patient from Peru who has a relatively low chance $(13 \%)$ of having a non-normal phenotype (10). Since $50-70 \%$ of antidepressants and antipsychotics are metabolized by one of these CYP enzymes, regular dosing 
Summary of main findings and general discussion

guidelines will not apply to most patients (https://www.gipdatabank.nl/servicepagina/open-data) $(3,4)$. The observed variation of genotypes between ethnicities worldwide strongly suggests that pre-emptive CYP genotyping should be performed for every patient who will need therapy involving drugs that are metabolized by CYP2D6 and/or CYP2C19 enzymes.

\section{Prevalences of CYP2D6 and CYP2C19 on Curaçao}

In one study, we looked in detail at the Caribbean island of Curaçao, part of the former Netherlands Antilles, and where the population is a mix between native inhabitants, immigrants and descendants of former African slaves. Earlier studies there showed that psychiatric patients were vulnerable for developing side effects such as movements disorders and metabolic syndrome $(8,65)$. We hypothesized that this vulnerability might be explained by a higher prevalence of slow medication metabolizers in the population. We therefore determined the prevalences of CYP2D6 and CYP2C19 genotypes on the island and, indeed, found a completely different allele composition than in Europeans, although the translation into predicted phenotypes showed an almost similar distribution between the two groups. These findings imply that, in the Netherlands, the same attention should be paid to altered drug metabolism in immigrant families from the former Netherlands Antilles as is paid to Europeans in clinical practice. Our results also suggested that the inhabitants of Curaçao are mainly an admixture of Europeans and Sub-Saharan Africans, with much less input from Asians.

In addition to the role of its polymorphisms in drug metabolism, it has also been suggested that CYP2D6 contributes to the susceptibility for schizophrenia, because of its role in the biotransformation of tyramine to dopamine (162). In a recent genome-wide association study, CYP2D6 expression was mentioned as a possible risk factor in the development of schizophrenia (250). In our study, we found no differences in CYP2D6 allele frequencies between psychiatric patients and the general island population. There is no evidence that CYP2D6 biotransformation of tyramine into dopamine actually increases susceptibility for schizophrenia. One explanation could be that studies that found lower percentages of poor metabolizers (PM) in patients with schizophrenia might have compared a selected inpatient group with healthy outpatient volunteers, which biased the results (67). In our study, almost $30 \%$ of our psychiatric population were outpatients, so the chances of bias were lower. Moreover, because our control group was from the same mixed ethnic background, our results were not affected by ethnic differences. We found no poor metabolizers of CYP2C19 in the psychiatric patients, in contrast to $4.1 \%$ in the volunteers from the general Antillean population. But because the *2 allele, which causes the PM phenotype $\left({ }^{*} 2 /{ }^{*} 2\right)$, was equally prevalent in both groups $(14.7 \%$ vs. 


\section{Chapter 6}

$16.2 \%, p=0.595)$, we think this finding is coincidental. The absence of poor metabolizers of CYP2C19 has also been reported in Panamanian Indian and Mexican populations $(182,183)$. The Indian heritage in the Netherlands Antilles could explain the low prevalence of CYP2C19 PM among our subjects. There is no convincing relationship between CYP2C19 and psychiatric symptoms (46).

\section{Analyzing functioning in patients with SMI using WHODAS 2.0}

While investigating the prevalence of CYP genotypes in the population of Curaçao, we also assessed the psychosocial functioning of those patients with severe mental illness (SMI). For years, treatment of psychiatric patients with severe psychiatric disorders has focused on their symptoms. The main treatment aim was remission of psychotic symptoms and behavioral problems. This approach is, however, not necessarily associated with better disease outcomes over time, since symptomatic remission is only partly connected to social functioning and quality of life (251). In recent years, treatment has focused on recovery, in which the most important goal is to regain a meaningful life in the community, including being able to participate in worthwhile activities and fulfilling social roles (205-208). We assessed the psychosocial functioning of patients with SMI using the World Health Organization Disability Assessment Schedule (WHODAS 2.0)(252).

Contrary to our expectations, we found that inpatients had fewer problems in participating in society than outpatients. We suggest being in the sheltered environment of a psychiatric hospital, with its associated adjustments in daily activities, may encourage participation in society. For example, nurses wake patients as part of their daily routine and help them attend creative and social activities organized by the hospital. Inpatients know each other and are mutually tolerant.

Another possibility is that inpatients and their healthcare professionals are accustomed to the status quo and may have lower expectations from life than outpatients (and their healthcare professionals) who are constantly confronted with their disabilities when in contact with society. These different frames of reference could partly explain the higher level of disfunction amongst outpatients.

Another important finding was the relationship between side effects and psychosocial functioning. Particularly drug-induced parkinsonism was associated with a broad spectrum of psychosocial disabilities, such as getting around and performing household activities. This is good reason for psychiatrists to pay more attention to the effect of adjusting dose to the CYP2D6 phenotype, in patients with parkinsonism. 
Effectivity of CYP2D6 genotyping

In our patients with SMI on Curaçao, we also planned to investigate the effectivity of CYP genotyping on treatment outcomes. At the start of the project, we intended to evaluate dose adjustments to the CYP2C19 phenotype as well. Although about $60 \%$ of our patients had a non-normal CYP2C19 predicted phenotype, we were not able to include any in our study who needed a dose adjustment according to the guidelines (there were no patients with a non-normal CYP2C19 phenotype using medication metabolized by the CYP2C19 enzyme). CYP2C19 genotyping therefore had no added value in this group. In other populations, where patients are mainly prescribed medication metabolized by the CYP2C19 enzyme, genotyping may well predict response in certain individuals, but it is not yet clear if this will translate to better clinical outcomes (253).

Before we could make dose adjustments to the CYP2D6 phenotype, we had to find out if psychiatrists had already adjusted doses because of side effects or treatment resistance. By recalculating the medication doses to a Defined Daily Dose (DDD), we found that the average DDD in the whole group was 1.68 (SD 0.92). There was no correlation between the predicted phenotypes and the prescribed dose of antipsychotics (Figure 2, chapter 4), PMs, IMs and UMs were prescribed the same amounts of psychopharmacological medication as the NMs, even when we only included antipsychotics metabolized by the CYP2D6 enzyme. We even found higher doses of antipsychotic medication in slow metabolizers (PM 1.86 (SD 1.21) vs. UM 1.12 (SD 0.44), $p=0.16$ ) (Figure 2, chapter 4), and again when we analyzed the DDD of medication metabolized by the CYP2D6 enzyme.

In a Russian study of inpatients with schizophrenia, there were also no differences found in mean dose of antipsychotic medication between the CYP2D6 metabolizer groups with an average DDD 1.7 (254). In a Swedish study, significantly lower doses of antipsychotics were found in PM- than EM outpatients. This could be due to a lower average prescribed DDD in this group of patients (DDD $=0.6$ ), which would make any differences in the effects of medication more clear than in patients on higher doses (255).

When we compared the in- and outpatients in our population, we found a DDD = 1.8 in the inpatient group versus a DDD $=1.2$ in the outpatient group $(p<0.001)$. In the outpatient group, we did not find a correlation between CYP2D6 activity level and DDD. Apparently, the clinical differences seen in tardive dyskinesia and parkinsonism are not large enough to stimulate psychiatrists to adjust dose to an individual phenotype. Our results also confirmed this: we found no differences in drug-induced movement disorders nor in metabolic parameters between the different metabolizer groups. Thus, it is even more important to study whether CYP 


\section{Chapter 6}

genotyping and medication adjustments actually result in better treatment outcomes.

Many antipsychotics, especially those metabolized by CYP2D6 (haloperidol, aripiprazole and risperidone) have bell-shaped dose-response curves, which means that treatment response decreases if the dose is are higher than optimal (256). With these types of antipsychotics, PMs automatically have a higher chance of being prescribed a dose above the optimal one for them and therefore a lower treatment response. Also, higher plasma levels of antipsychotic medication show lower levels of subjective wellbeing in patients with schizophrenia (257). Positron emission tomography (PET) studies showed that when dopamine 2 receptor occupancy exceeds $78 \%$, the likelihood of extra pyramidal symptoms is significantly increased, whereas an occupancy between $60-70 \%$ is optimal in patients with schizophrenia $(41,157)$. It could be that doses were far above the $78 \%$ occupancy even after dose reduction and that might explain why we found no differences in symptoms between the two groups (Figure 1). Some studies found differences in tardive dyskinesia and parkinsonism between patients with a normal (NM) and a reduced metabolism (PM + IM). Patients in these studies were also taking antipsychotic medication long term, but again in significantly lower doses (DDD $=0.3-1)(43,160,258,259)$. 
Figure 1. Schematic adaptations of the dose concentration relationship, after a single dose of antipsychotic medication, before and after $\mathbf{5 0 \%}$ dose reduction
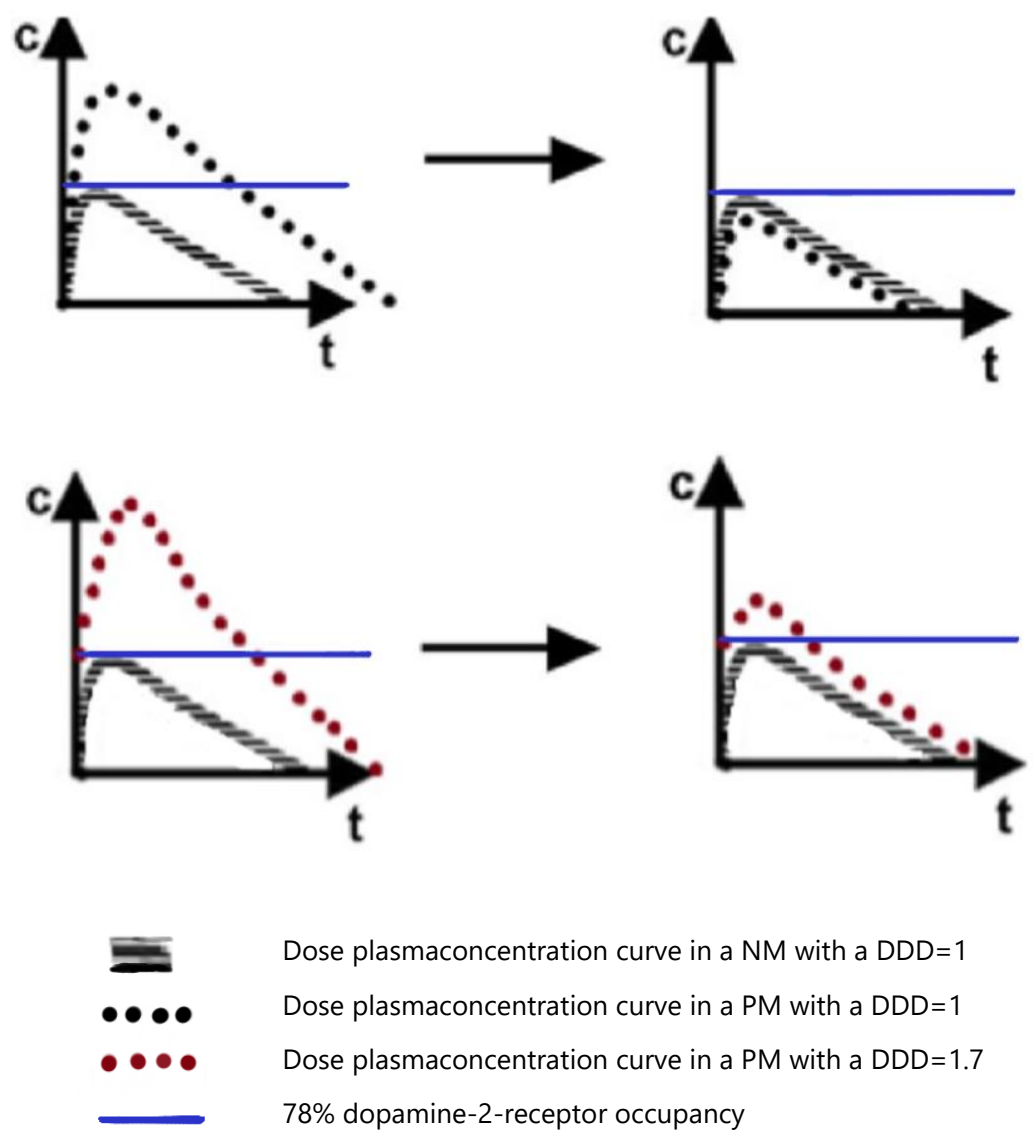

$D D D=$ Defined Daily Dose, $c=$ concentration of drugs in blood, $t=$ time in hours

Most of the studies on movements disorders between metabolizer groups were underpowered and the results did not reach significant difference. When the results were pooled in a meta-analysis, the differences in severity of drug-induced movement disorders were considered too small to be clinically meaningful $(O R=$ 1.24) $(27,160,258-260)$. We also found no differences at the start of our study, nor a trend toward improvement after dose adjustment. Even in a subanalysis of 16 patients using small doses (DDD $\leq 1.0$ ), we saw no improvements in the intervention group. This supports the idea that differences in movements disorders between 


\section{Chapter 6}

metabolizer groups are too small to be demonstrated in small clinical trials or in clinical practice.

Another explanation for the lack of effect from CYP genotyping on psychiatric symptoms or side effects could be that long-term use of antipsychotics induces structural changes in the brain (132). In a review, the process of sensitization and tolerance to antipsychotics was proposed to explain why clinical trials fail to demonstrate efficacy of novel treatments (261); and chronic use of antipsychotics induced changes in neuroplasticity and the patient's brain became sensitive to antipsychotic medication (262). Sensitization leads to increased behavioral side effects. A prior antipsychotic treatment history and subsequent withdrawal because of dose adjustment could cause a 'supersensitivity psychosis', i.e. a drug-induced psychotic relapse following an interruption of chronic antipsychotic treatment. The drug-induced increase in the mesolimbic dopamine postsynaptic D2 (high) receptors, which has been shown in animal models, is suggested to be the underlying mechanism (263). A Japanese study has shown a higher prevalence of supersensitivity psychosis in CYP2D6 poor metabolizers, although the results did not reach significance. They hypothesized that a higher risperidone concentration in PMs leads to a higher risk of this type of psychosis (264). The supersensitivity psychosis might explain the deterioration of some patients after dose adjustment in our study sample $(n=6)$.

Liu and Takeuchi have recently proposed an algorithm for dose reduction of antipsychotics with only a fraction (no more than 25\%) of the dose to be reduced at any time, and with at least a 6 -month stabilization period to prevent psychotic decompensation (265). This is in marked contrast with the $50 \%$ dose reduction, taken in two steps over 4 months, we adopted in our study setting.

More support for this sensitivity hypothesis is that drug-induced movement disorders are not as reversible as initially thought. Earlier studies reported that only $3 \%$ of patients who discontinued the drugs causing their movement disorder showed improvement in tardive syndromes (133). A lower dose of antipsychotics did not decrease the severity of parkinsonism in patients with SMI on high doses (66). In this clinical population, perhaps a dose adjustment to match their CYP2D6 phenotype would have had an effect in an earlier phase of treatment, but the years had led to irreversible neuroplastic changes.

When we searched the literature, we found most of the studies reporting potential clinical benefits from CYP genotyping were observational; they found extreme metabolizers had longer stays in psychiatric hospital $(5,42,138,266)$. We found only three prospective studies that reported an effect of CYP genotyping on side effects for patients with schizophrenia with non-normal CYP2D6 metabolizer profiles $(7,43,254)$. There were two differences between these studies and our study. First, in 
two studies reporting on the average dose of antipsychotics, the average DDD was around 1 compared with DDD = 1.68 in our population. Second, in all three studies, patients were selected for CYP genotyping when there was an intention to start antipsychotic treatment or to switch drug type, and clinical reasoning was part of the decision to adopt genotype-guided treatment. In the study by Herbild et al., for example, there was only the additional information on the patient's genotype and a recommendation to adjust the pharmacological treatment accordingly, but the decision adjust the dose was left to the clinician. Our study was different in the timing and instructions on dose adjustment: there was no clinical reason to genotype the patients and the dose reductions were purely guided by genotype and not by the patient's clinical symptoms. Many of the patients in our study who received adjustments were already relatively stable on their dose regimes, although their doses were high, they were suffering from diverse side effects, and many were admitted to psychiatric wards for chronically ill patients.

This means that in other studies finding an effect of CYP genotyping, there was already a clinical reason or intention to change from standard dosing regimens. These patients were not stable on their dosing regimens or were suffering from so many side effects that they had already requested a change in medication. In our study, every patient's dose was adjusted, clinical symptoms were not taken into account. We excluded only those patients who were unwilling to have their dose adjusted $(n=3)$. It is possible that a selected group of patients who do not respond on standard treatment regimes would see more benefit from genotype-guided treatment. This could be revealed when there is a reassessment of the standard treatment and/or when clinical pros and cons are being carefully weighed. The large group of patients who benefit from standard treatment without too many side effects would not necessarily benefit more from genotype-guided treatment and dose adjustments. In 15\% (6/45) of the patients we investigated adjusting the dose even caused their condition to deteriorate.

\section{Pharmacokinetics}

The majority of evidence for CYP genotyping in pharmaceutical guidelines comes from studies on the relationship between CYP activity and the plasma concentrations of psychiatric medication (267-269). The relationship between the plasma concentration of antipsychotic medication and clinical outcomes is a topic of ongoing debate. For example, some studies found no correlation between plasma concentration of active moiety and clinical efficacy of risperidone $(270,271)$.

We were able to measure the plasma levels of haloperidol, zuclopenthixol and risperidone in 31 patients at the start of the study. Only for risperidone was there a moderate correlation between metabolic activity and plasma level (Pearson 


\section{Chapter 6}

correlation coefficient $-0.5 ; p=0.08$ ) (with higher plasma levels in PMs than in NMs and UMs). This is in line with another study that found a correlation between risperidone concentration and CYP2D6 activity (272). However, it is in contrast with studies in natural cohorts of patients with schizophrenia that found correlations between haloperidol and zuclopenthixol plasma levels and CYP2D6 activity $(22,258)$. It should be noted that, in those studies, body weight and smoking were equally important determinants of haloperidol clearance.

\section{Conclusions}

Since 1988, more than 3000 papers on CYP2D6 and/or CYP2C19 have been published. Probability estimates of a person having a non-normal metabolizer profile show that about 36.4\% (CYP2D6) and 61.9\% (CYP2C19) of the world population has a non-normal metabolism, which suggests that genotyping may be highly relevant to clinical practice. This is supported by pharmacokinetic studies. However, these studies have mostly been conducted by pharmacologists and pharmacogeneticists, and they do not offer translation of genotyping results to clinical practice. This thesis has attempted to bridge the gap between the evidence from pharmacogenetic studies and psychiatric practice.

The majority of the evidence for current treatment guidelines comes from studies on the relationship between CYP activity and plasma levels of psychiatric medication (267-269). Although plasma levels are clinically relevant, the 'proof of the pudding' is if genotype-guided treatment results in more effectivity and/or fewer or less severe side effects.

Studies showing trends in clinical validity in patients with SMI are often underpowered. Patient groups on lower doses of antipsychotics seem to benefit the most from genotype-guided treatment. There is also some evidence that CYP2D6 and CYP2C19 genotyping, as additional information next to clinical considerations, can benefit treatment outcomes (psychopathology and side effects).

Although it might appear that genotyping is without risk, our study of 45 patients showed that six deteriorated after their dose was adjusted, including two who had to be admitted to a psychiatric hospital because of psychotic decompensation.

It could be that in patients on years of antipsychotic treatment, following genotyping guidelines without carefully considering clinical symptoms and side effects, will do more harm than good. 
Directions for further research

The results of this thesis call for modesty regarding the benefits of genotyping in patients with severe mental illness. Future studies should focus on the clinical utility of CYP genotyping in psychiatric practice. First, patients with SMI have often been using antipsychotic medication for several years. Irreversible neuroplastic changes in the brain might explain the negative results for CYP genotyping in our study. It is therefore necessary to study if genotyping should be used at an earlier phase of the disorder, in patients without a medication history. It might even prevent the development toward SMI. Future studies should be performed prospectively and focus on patients with a first psychotic episode, with a blank or short history of antipsychotic use.

Second, studies providing evidence for cost effectiveness show that differences between metabolizer groups only become significant when patients using medication not metabolized by CYP2D6 are excluded from the analysis (42). Studies also easily become underpowered when patients with a normal metabolizer phenotype are included in the analysis (7). This means that to be able to estimate effects of routine CYP2D6 genotyping, the studies should include large numbers of patients using medications metabolized by CYP2D6.

In the Netherlands, antipsychotics metabolized by CYP2D6 (haloperidol, risperidone, aripiprazole and zuclopenthixol) form $41 \%$ of that medication prescribed (https://www.gipdatabank.nl/servicepagina/open-data)(2017). In about 36\% (PM + IM+ UM) of these patients (273), the Royal Association for the Advancement of Pharmacy would advise adjusting the dose to phenotype $(44,85)$. Thus, if all patients using antipsychotics are genotyped for CYP2D 6 , around $15 \%(0.41 * 0.36)$ of them may benefit from dose adjustment. This means that about seven patients have to be genotyped for one patient to benefit from genotype-guided dose adjustments in one patient, or in other words, the number to screen is seven.

Large randomized controlled trials are therefore needed. Confounders such as inhibiting medication, treatment adherence, drug and alcohol use, and inflammation should be considered and drug-plasma levels should be measured. When evaluating the outcomes, the focus should not only be on primary disease symptoms and side effects, but also on recovery of function. In patients with cognitive deficits or lack of disease insight, the WHODAS 2.0 proxy version proved to be a powerful clinical instrument.

Lastly, research on genotype frequencies should focus on regions that are underinvestigated such as the Middle East and Africa. When individuals are included in a study, their ethnicity must be well defined, preferably by confirming three generations of lineage. Most importantly, a minimum number of alleles and 


\section{Chapter 6}

duplications must be investigated to avoid overestimation of the wildtype/normal phenotype.

This thesis shows there are many studies that hold value for clinical practice, but the field would benefit from much more communication between the disciplines to make evidence from the laboratory useful for patients in clinical practice. 


\section{CHAPTER 7}

Impact of the thesis on the scientific and social community 

According to the global burden of disease studies, about $16 \%$ of the global population is suffering from a mental disorder or addiction (274). A considerable amount of these patients uses antipsychotic or antidepressant medication. Mental disorders cause considerable burden of disease, in 2016 globally, 162.5 million Disability Adjusted Life Years (DALYs) were lost due to mental or addictive disorders, about $7 \%$ of all DALYs lost by disease (274).

In 2017, almost 1.5 million people in the Netherlands, were prescribed an antidepressant or antipsychotic drug

(https://www.gipdatabank.nl/servicepagina/open-data). Unfortunately, many of these patients discontinue their treatment because of in-effectivity of the treatment or life-influencing side effects $(1,240,241)$. Patients with SMI, with a long history of antidepressant or antipsychotic drugs, are especially known to suffer from problems with adverse drug reactions and lack of medication effect $(1,69,70)$. Side-effects can impair psychosocial functioning and may influence the quality of life $(1,186)$. There is a need for tools which enhance effectivity and lower the risk on side-effects of pharmacological treatment.

Of specific interest are the activity of the CYP2D6 and CYP2C19 enzymes because about $50-75 \%$ of all antidepressant and antipsychotic drugs is metabolized by either one of these enzymes (https://www.gipdatabank.nl/servicepagina/open-data) $(29,275)$. There are studies showing that the activity of the CYP2D6 and the CYP2C19 enzymes is related to the prevalence of side effects and treatment response $(6,22)$. Also, the costs of treatment and length of hospitalization of poor metabolizers (PMs) and ultrarapid metabolizers (UMs) are on average, longer than of intermediate metabolizers (IMs) and normal metabolizers (NMs) $(5,42)$. In a cost analysis study in patients with schizophrenia in Denmark, overall health costs were found to be $177 \%$ higher in all extreme metabolizers (PM + UM) compared to NMs and that genotyping could lead to lower treatment costs (7). A study in patients with schizophrenia showed that patients receiving pharmacogenetic testing prior to a switch or start of antipsychotics showed some improvement in side effects compared to the patients receiving treatment as usual, even though effects were minimal and not significant (43). It is hypothesized that CYP genotyping can lead to better treatment outcomes and reduced treatment costs (7).

Precision or personalized medicine may optimize treatment decisions by a tailormade strategy for each individual patient. Pharmacogenetic testing is becoming more and more available and prices of testing are dropping (276). A genetic test for CYP2D6 and CYP2C19 costs about $€ 260$ in an academic hospital in the Netherlands (Erasmus Mc Rotterdam). It is becoming available for a bigger public and psychiatrists are encouraged to perform pharmacogenetic testing. In some hospitals, testing is routine practice, while in others pharmacogenetic testing is seldom done. There are guidelines from the Royal Dutch Association for the Advancement of 


\section{Chapter 7}

Pharmacy available with instruction how to handle with the outcomes of a genetic test, but there are still some issues to address before implementing it in clinical practice.

First, there is a lack of communication between test manufacturers and clinicians, which is required to narrow the gap between the availability and implementation of these tests in psychiatric practice (276). Second, there is still no consensus under psychiatrists if genotyping is (cost) effective and which patient groups could benefit from this diagnostic tool.

This thesis aimed to narrow the gap between evidence from pharmacogenetic studies and clinical psychiatric practice. It is intended to facilitate the clinical working doctor (general practitioners, psychiatrists and all medical doctors prescribing antidepressants or antipsychotics), especially those working with patients with SMI.

We investigated the probability of having a non-normal phenotype in different ethnicities and analyzed whether CYP genotyping could yield better treatment outcomes (psychopathology, side-effects and functioning) for patients with Severe Mental Illness.

In this thesis we introduced a new term: 'non-normal probability estimate'. Introducing this term to the field of pharmacogenomics made it possible to see which ethnicities are at the highest risk for developing dose dependent side effects or treatment failure. The information is presented in world maps, and for the first time it is visualized which world areas are under investigated and have to be focus of research. The prevalence of non-normal CYP2D6 and CYP2C19 phenotypes for the different ethnicities are gathered in two world maps, which is an important step in a globalizing world and may be especially helpful in the treatment of migrants.

We found that $36 \%$ of the world population is having a non-normal CYP2D6 phenotype and that $62 \%$ is having a non-normal CYP2C19 phenotype. We know now, that to come to a reliable test outcome, one should minimally genotype alleles, that are prevalent in the specific geographic region a patient is from. In inhabitants from the former Netherlands Antilles the same attention should be paid to altered drug clearance, as is paid to Europeans.

Also, we conclude that for patients with SMI on years of antipsychotic treatment, CYP2D6 genotyping is not effective. CYP genotyping did not show any effects on side-effects, psychopathology, functioning or quality of life. Pre-existent high maintenance dosages, irreversibility of side effects and adaptation of the brain to years of D2 receptor antagonism, are possible explanations why genotyping in this population did not show a beneficial effect on one of these parameters. This study is suggesting that routine genotyping in this patient population is not effective and urges to modesty in genotyping. This insight saves us from needless diagnostic testing and pseudo-certainty about medication effects. Although it seems that, 
besides extra costs, genotyping is without risk, our study showed that six patients deteriorated after dose adjustment and even two patients had to be admitted in psychiatric hospital because of psychotic decompensation. When following genotyping guidelines without carefully considering clinical symptoms and side effects it could be that genotype guided treatment will do more harm than good. It is highly necessary to study if genotyping in an earlier phase of the disorder, in patients without a long medication history, may be beneficial in terms of effectiveness and side effect profile.

Lastly, we found that the proxy version of the WHODAS 2.0 is a useful instrument for measuring functioning when patients are not able to complete the questionnaire themselves.

The results of the thesis have been published in four scientific journals, of which three are in open access journals and one journal which supplies the article to membered universities or after payment. To inform a broader public of clinicians working in the Netherlands, an article in Dutch will be written and will be submitted to The Journal of Psychiatry.

Individual test outcomes were communicated to general practitioners and pharmacists in the Netherlands and to the psychiatrists at Curaçao. Wherever there were questions about the relevance or practical implications of the test outcomes, they were answered according to the latest scientific knowledge. Findings from the studies were presented at diverse congresses and symposia worldwide. The committee that is writing the Dutch guideline Pharmacogenetics in Psychiatry personally have been informed of the results of the study that shows that routine genotyping in patients with SMI did not show any beneficial effects. Table 1 is summarizing where the research for this thesis was presented. In these meetings, clinicians, fellow researchers and policy makers were informed about the latest results and invited to discuss the possible benefits from genotyping in clinical practice.

Results of the meta-analysis about worldwide prevalence of CYP2D6 and CYP2C19 phenotypes and the non-normal probability estimates, are freely available for a bigger public on the website www.ethnopsychopharmacology.com. This website is an initiative from Prof. M. Braakman and is a platform for scientific data about psychopharmacology and ethnicity. 


\section{Chapter 7}

Table 1. Congresses at which (preliminary) findings of this thesis were presented

\begin{tabular}{|c|c|c|c|}
\hline DATE & MEETING & TYPE & PLACE \\
\hline 2014 & ZonMw Diversity congress & oral presentation & $\begin{array}{l}\text { The Hague, the } \\
\text { Netherlands }\end{array}$ \\
\hline 2014 & $\begin{array}{l}\text { Educational presentation for doctors } \\
\text { in training to psychiatrist, Parnassia } \\
\text { Group The Hague }\end{array}$ & oral presentation & $\begin{array}{l}\text { The Hague, the } \\
\text { Netherlands }\end{array}$ \\
\hline 2014 & $\begin{array}{l}\text { Congress of Dutch Caribbean } \\
\text { foundation for clinical higher } \\
\text { education (NASKHO) }\end{array}$ & workshop & Willemstad, Curaçao \\
\hline 2015 & $\begin{array}{l}\text { Research day of School for Mental } \\
\text { Health \& Neuroscience Research } \\
\text { (MHENS) Maastricht university }\end{array}$ & poster presentation & $\begin{array}{l}\text { Maastricht, the } \\
\text { Netherlands }\end{array}$ \\
\hline 2016 & $\begin{array}{l}\text { Congress of Dutch Association for } \\
\text { Psychiatry (NVvP) }\end{array}$ & poster presentation & $\begin{array}{l}\text { Maastricht, the } \\
\text { Netherlands }\end{array}$ \\
\hline 2017 & $\begin{array}{l}\text { European Conference of } \\
\text { Schizophrenia Research (ECSR) }\end{array}$ & workshop & Berlin, Germany \\
\hline 2018 & $\begin{array}{l}\text { Congress of Dutch Association for } \\
\text { Psychiatry (NVvP) }\end{array}$ & workshop & $\begin{array}{l}\text { Maastricht, the } \\
\text { Netherlands }\end{array}$ \\
\hline 2018 & $\begin{array}{l}\text { American Psychiatric Association } \\
\text { (APA) Research Program }\end{array}$ & $\begin{array}{l}\text { oral presentation+ } \\
\text { poster presentation }\end{array}$ & New York, USA \\
\hline 2019 & $\begin{array}{l}\text { Scientific-Educational program of } \\
\text { Education Consortium } \\
\text { Parnassia-LUMC-Rivierduinen }\end{array}$ & oral presentation & $\begin{array}{l}\text { Leiden, the } \\
\text { Netherlands }\end{array}$ \\
\hline
\end{tabular}




\section{ADDENDUM}

Nederlandse samenvatting

List of abbreviations

References

Supplemental material

Dankwoord

Curriculum Vitae 


\section{NEDERLANDSE SAMENVATTING}

De enzymen CYP2D6 en CYP2C19, werkzaam in de lever, spelen een belangrijk rol in de afbraak van bijna alle antipsychotica en antidepressiva. CYP2D6 is verantwoordelijk voor de afbraak van o.a. haloperidol, aripiprazol, risperidon, amitriptyline en nortriptyline (29). CYP2C19 o.a. voor de afbraak van citalopram, sertraline en clomipramine (29). Er zijn allerlei factoren van invloed op de snelheid waarmee deze enzymen medicatie afbreken, bijvoorbeeld het gebruik van alcohol, drugs, sigaretten, medicatie en ook voeding, zwangerschap of infecties (14-19). Eén van de belangrijkste factoren is echter de manier waarop het enzym gecodeerd is in het DNA, ook wel het polymorfisme genoemd. Elk enzym wordt gecodeerd door twee allelen en afhankelijk van het aantal actieve allelen kan het genotype vertaald worden naar een fenotype. De fenotypen van CYP2D6 en CYP2C19 worden ingedeeld in vier groepen: trage metaboliseerders (PM), intermediaire metaboliseerders (IM), normale metaboliseerders (NM, voorheen EM) en ultrasnelle metaboliseerders (UM) (33). Een snel CYP2D6 en/of CYP2C19 metabolisme leidt bij een normale dosering tot een lagere dan gemiddelde spiegel van het medicament en veelal tot verminderde effectiviteit omdat het medicijn sneller uit het lichaam verwijderd wordt en dus minder lang werkzaam is. Terwijl een langzaam metabolisme bij een normale dosering leidt tot een hogere dan gemiddelde spiegel en vaak tot meer (dosisafhankelijke) bijwerkingen (20-25). Naast verhoogde gevoeligheid voor bijwerkingen is er ook een verband aangetoond tussen een vertraagd fenotype en hogere zorgkosten $(7,42)$. Snelle metaboliseerders bleven achteraf gezien langer opgenomen in het ziekenhuis omdat het langer duurde voordat ze goed waren ingesteld op medicatie $(5,42,138,266)$. Richtlijnen adviseren om dosisaanpassingen te doen bij patiënten met een PM, IM of UM-fenotype om een optimaal effect te bewerkstellingen en bijwerkingen terug te dringen. Het is echter niet duidelijk of het bepalen van CYP2D6 en CYP2C19 in de praktijk ook leidt tot meer effectiviteit en minder bijwerkingen. Er is veel discussie in de recente literatuur of we nu juist wel of niet vaker moeten genotyperen $(2,277,278)$. In 2018 ging er zelfs een waarschuwing uit van de FDA (Food and Drug Administration) dat er onvoldoende evidentie was voor het op grote schaal klinisch toepassen van CYP genotypering (247). Het is dus belangrijk om hier meer duidelijkheid over te krijgen.

Prevalentie van de verschillende allelen en dus ook de fenotypen verschillen sterk per etniciteit. Bijvoorbeeld, in Europese populaties is de prevalentie van CYP2D6 UM $3 \%$ in vergelijking tot $20-29 \%$ in Afrikaanse populaties (11,81). CYP2C19 PMs komen vaker voor in Azië (12\%) dan in Europa (2\%) (82). In hoofdstuk 2, hebben wij onderzocht hoe vaak de deze fenotypen wereldwijd voorkomen en welke etniciteiten de grootste kans hebben op een niet-normaal fenotype. De kans op een nietnormaal fenotype is gedefinieerd als de prevalentie van PM + IM + UM. We konden uiteindelijk 118 studies includeren in de meta-analyse. We vonden dat wereldwijd de 
kans op een niet-normaal CYP2D6 fenotype 36\% en een niet normaal CYP2C19 fenotype $62 \%$ is. Dit betekent dat meer dan de helft van de wereldbevolking een niet-normaal CYP2D6 en/of CYP2C19 fenotype heeft. De kansen op een niet-normaal fenotype hebben we weergegeven in wereldkaarten. Op die manier is ook duidelijk geworden dat er met name in Afrika en het Midden-Oosten nog weinig prevalentie onderzoek gedaan is.

Het eiland Curaçao, onderdeel van de voormalige Nederlandse Antillen, heeft een populatie met een diverse genetische achtergrond. Het grootste deel van de bewoners stamt af van de slaven uit West-Afrika. Er is verder vermenging met de inheemse Indiaanse populatie en er zijn Chinezen, Europeanen en Zuid-Amerikanen naar het eiland gemigreerd. Deze bijzondere combinatie aan afstammelingen heeft geleid tot een bevolkingsgroep met een eigen unieke DNA-samenstelling. Het is echter nog onbekend wat de prevalentie is van de CYP2D6 en CYP2C19 fenotypen. In sommige populaties in de Latijns-Amerikaanse regio is de prevalentie van PMs extreem hoog (10\%). Daarnaast is het aantal psychiatrische patiënten dat last heeft van bijwerkingen hoog. Zo werd in eerdere studie (The Curaçao Extrapyramidal Symptoms Study) aangetoond dat door medicatie-geïnduceerde bewegingsstoornissen vaak voorkomen en soms heftig verlopen (8). Voorbeelden van dit soort bewegingsstoornissen zijn: parkinsonisme, (combinatie van tremor, bewegingsarmoede en rigiditeit), dyskinesie (onwillekeurige spierbewegingen) en acathisie (bewegingsonrust). Zou het mogelijk zijn om dit soort bijwerkingen te verminderen als we de medicatie aan zouden passen aan de CYP fenotypen?

In hoofdstuk 3 hebben wij onderzocht hoe vaak de fenotypen voorkomen op Curaçao. De onderzochte groep bestond uit een 269 psychiatrische patiënten op Curaçao en 166 mensen uit de algemene bevolking afkomstig van Curaçao woonachtig in Nederland. De prevalentie van de CYP2D6 fenotypen zijn als volgt: $\mathrm{PM}=5 \%, \mathrm{IM}=32 \%, \mathrm{NM}=61 \%$ en $\mathrm{UM}=2 \%$. De prevalentie van de CYP2C19 fenotypen zijn $\mathrm{PM}=2 \%, \mathrm{IM}=27 \%, \mathrm{NM}=40 \%$ en $\mathrm{UM}=31 \%$. Deze prevalenties blijken zeer vergelijkbaar met die van Europeanen. Er zijn geen verschillen in prevalentie tussen psychiatrische patiënten en niet-psychiatrische vrijwilligers gevonden.

In hoofdstuk 4 hebben we onderzocht of het bepalen van de genotypen van CYP2D6 en CYP2C19 zinvol kan zijn bij patiënten met ernstige psychiatrische aandoeningen (EPA).

Om de effectiviteit van CYP2D6 en CYP2C19 genotypering in patiënten met EPA te onderzoeken hebben we uit de groep van 269 patiënten waarvan we het genotype bepaald hadden, alle patiënten geselecteerd met een niet-normaal CYP2D6 en/of CYP2C19 fenotype en medicatie gebruik door het betreffende metaboliserende enzym. We konden 45 patiënten includeren die op basis van de richtlijn van de KNMP 
een dosis aanpassing nodig hadden op basis van hun fenotype. Zij werden gematcht met een controlegroep van $41 \mathrm{NM}$-patiënten. Alle 45 patiënten werden geselecteerd vanwege een dosisaanpassing op basis van het CYP2D6 profiel, er waren geen patiënten met een niet-normaal CYP2C19 fenotype en medicatie gemetaboliseerd door CYP2C19. De patiënten werden vóór en vier maanden na de dosisaanpassing gemeten op psychopathologie, metabole bijwerkingen en bewegingsstoornissen, sociaal functioneren en kwaliteit van leven. Bij aanvang van de studie werd geen verschil in gemiddelde-dosering-voorgeschreven-antipsychotica tussen de verschillende fenotypen gevonden. Blijkbaar deden artsen geen aanpassing naar het fenotype op basis van klinische verschillen, mogelijk omdat de verschillen klinisch onvoldoende zichtbaar waren. Er waren geen verschillen in psychopathologie, bijwerkingen, het functioneren en kwaliteit van leven tussen de dosisaanpassing- en de controlegroep vóór en na de dosisverandering. Wij hebben hieruit geconcludeerd dat dosisaanpassing op basis van CYP2D6 fenotype geen effectieve interventie is in psychiatrische patiënten reeds langdurig ingesteld op antipsychotica. We hebben hiervoor verschillende mogelijke verklaringen.

Allereerst denken we dat langdurig antipsychotica leidt tot adaptatie aan veranderde dopamineconcentraties waardoor chronisch gebruik leidt tot structurele veranderingen in breinvolume, dopamine-2 en serotonine receptor concentratie en verhoogde affiniteit van de dopaminereceptor voor endogeen dopamine $(132,261,262)$. Er zijn studies die laten zien dat bewegingsstoornissen als gevolg van langdurig antipsychotica gebruik niet in remissie gaan als de medicatie in dosering verlaagd of gestaakt wordt, terwijl dit wel altijd verondersteld werd $(66,133)$. Tevens zijn er aanwijzingen voor het controversiële idee dat chronische blootstelling aan antipsychotica leidt tot verhoogde gevoeligheid voor psychose (262). Deze verhoogde gevoeligheid wordt ook wel het 'Dopamine Supersensitiviteit Syndroom' genoemd $(261,263)$. Bij afbouwen van medicatie kan er een 'supersensitiviteitspsychose' ontstaan als gevolg van supergevoelige dopamine 2 receptoren die zonder antipsychotica direct ontregelen. Dit mechanisme zou verklaren waarom een groot gedeelte $(n=6)$ van de patiënten die een dosisaanpassingen hadden gekregen decompenseerde na dosisaanpassing.

Een tweede verklaring voor het uitblijven van effect van dosisaanpassing, is dat patiënten relatief hoge doseringen antipsychotica gebruikten (DDD = 1.68). Mogelijk is dit ook gerelateerd aan de veronderstelling dat sensitiviteit voor dopamine vraagt om steeds verdere verhoging van de dosering om psychose te voorkomen. Eerder is in onderzoek aangetoond dat er boven een bepaalde dopamine D2 receptor bezetting een aanzienlijk grotere kans is op bewegingsstoornissen (41). De kans is groot dat de patiënten die dosisaanpassing hebben gekregen nog steeds ver boven die bezettingsgraad zaten waardoor de dosisverlaging geen invloed heeft gehad op deze bijwerkingen. 
Dit betekent dat in de dagelijkse klinische praktijk bij patiënten reeds ingesteld op antipsychotica, CYP2D6 genotypering vooralsnog geen routinematige interventie hoeft te worden. Omdat het uitblijven van een effect voor een belangrijk deel verklaard wordt door het feit dat patiënten reeds ingesteld waren op medicatie, zouden wij toekomstige onderzoekers adviseren zich te richten op patiënten zonder medicatievoorgeschiedenis.

Wij hebben in hoofdstuk 5 onderzocht, of de WHODAS 2.0 proxy-versie (World Health Organization Disability Assessment Score) waardevolle informatie kan geven over het functioneren van patiënten met ernstige psychiatrische aandoeningen. De WHODAS 2.0 is opgenomen in de DSM-5 ter vervanging van de GAF (Global Assessment of Functioning), het is een vragenlijst die is ontwikkeld om ziekte en cultuur overstijgend te meten hoeveel last mensen hebben van een aandoening in het dagelijks leven (211). Patiënten met ernstige psychiatrische aandoeningen (schizofrenie, bipolaire stoornis, ernstige depressieve stoornis) hebben echter vaak last van cognitieve stoornissen waardoor het soms moeite kost de aandacht bij de vragenlijsten te houden $(75,76,216)$. Soms zorgt beperkt ziekte-inzicht tot andere uitkomsten dan wordt ingeschat door behandelaren of naasten. Wij hebben bij 77 verzorgers van patiënten met EPA deze vragenlijst afgenomen en een goed beeld gekregen van het functioneren van deze patiënten. De hoogste scores voor disfunctioneren werden gevonden in de domeinen die gingen over interacties met andere mensen en deelname van de samenleving. Tegen onze verwachting in vonden wij dat opgenomen patiënten minder moeite hadden met deelname aan de samenleving dan ambulante patiënten. Een verklaring zou kunnen zijn dat de samenleving waarin de opgenomen patiënten deelnemen beschermd is en dat dagelijkse activiteiten aangepast zijn aan de mate van disfunctioneren waardoor deelname relatief makkelijk is. Het zou echter ook zo kunnen zijn dat verzorgenden van opgenomen patiënten een ander referentiekader gebruiken dan verzorgenden van ambulante patiënten. Een andere belangrijke bevinding was dat de bijwerking parkinsonisme geassocieerd is met een breedspectrum van disfunctioneren zoals rondlopen en uitvoeren van huishoudelijke taken.

Concluderend, vonden wij dat wereldwijd de kans op een niet-normaal CYP2D6 fenotype $36 \%$ en een niet normaal CYP2C19 fenotype 62\% is. Dit betekent dat meer dan de helft van de wereldbevolking een niet-normaal CYP2D6 en/of CYP2C19 fenotype heeft. Dosisaanpassing op basis van fenotype bij patiënten reeds langdurige ingesteld op antipsychotica, op het eiland Curaçao is echter niet zinvol gebleken. Terwijl de verdeling van de fenotypen bij bewoners van Curaçao, zeer vergelijkbaar is met die van gezonde vrijwilligers en met de verdeling van fenotypen onder Europeanen. De proxy-versie van de WHODAS 2.0, opgenomen in de DSM-5 ter vervanging van de GAF, is een klinisch bruikbaar instrument om functioneren te meten bij patiënten met ernstige psychiatrische aandoeningen. 
Aanbevelingen voor de toekomst

Hoewel er multipele studies zijn, die het verband aantonen tussen CYP enzymen en de hoogte van de bloedspiegel van een medicament, zijn er slechts enkele studies die onderzoek hebben gedaan naar het effect van genotypering op klinische uitkomsten. Het grotendeel van de studies bij patiënten met antipsychotica gebruik zijn observationeel, retrospectief en hebben kleine patiënten aantallen. In Nederland wordt ongeveer $40 \%$ van de voorgeschreven antipsychotica (haloperidol, risperidone, aripiprazole en zuclopenthixol) gemetaboliseerd door CYP2D6. In ongeveer 36\% (PM + IM+ UM) van deze patiënten adviseert de KNMP een dosisaanpassing. Dit betekent dat $15 \%(0.41 * 0.36)$ van alle patiënten die gebruik maken van antipsychotica zouden kunnen profiteren van genotypering. Of te wel een 'number needed to screen' van 7.

Toekomstig onderzoek zou zich met behulp van een prospectief design, moeten richten op het effect van genotypering op behandeleffecten en bijwerkingen bij patiënten met een eerste psychotische episode die geen of een korte behandelvoorgeschiedenis hebben. 



\section{LIST OF ABBREVIATIONS}

$A B C=$ Aruba Bonaire Curaçao

ANCOVA = Analysis of Covariance

ANOVA = Analysis of Variance

BARS = Barnes Rating Scale for drug-induced akathisia

$\mathrm{BMI}=$ Body Mass Index

BPRS $=$ Brief Psychiatric Rating Scale

CEIBA = cocktail of caffeine, omeprazole, dextromethorphan and losartan

$\mathrm{CPIC}=$ Clinical pharmacogenetics implementation consortium

CYP2C19 = Cytochrome P450 2C19, member of the CYP2C subfamily

CYP2D6 = Cytochrome P450 2D6, member of the CYP2C subfamily

CYP450 = Cytochrome P450

DALY = Disability Adjusted Life Years

DDD = Defined Daily Dose

DNA = Deoxyribonucleic acid

DPWG = Dutch Pharmacogenetics Working Group

DSM-5 = Diagnostic and Statistical Manual of mental disorders

$\mathrm{EM}=$ Extensive Metabolizer

$E P A=$ Ernstige Psychiatrische Aandoeningen

Eq5D $=$ EQol 5-D

FDA $=$ Food and Drug Administration

GAF $=$ Global Assessment of Functioning

HWE = Hardy Weinberg Equilibrium

$\mathrm{IM}=$ Intermediate Metabolizer

KNMP = Koninklijke Maatschappij ter bevordering der Pharmacie

$\mathrm{NM}=$ Normal Metabolizer 
$N V v P=$ Nederlandse Vereniging voor Psychiatrie

PM = Poor Metabolizer

SAMSHA = Substance Abuse and Mental Health Services Administration

SD = Standard Deviation

SHRS $=$ St. Hans Rating Scale

$\mathrm{SMI}=$ Severe Mental IIInesS

SWN-20 = Subjective Well-being under Neuroleptics scale

$\mathrm{TCA}=$ Tricyclic Antidepressant

TDM = Therapeutic Drug Monitoring

$\mathrm{UM}=$ Ultrarapid Metabolizer

WHO $=$ World Health Organization

WHODAS 2.0 $=$ WHO Disability Assessment Schedule 2.0 


\section{REFERENCES}

1. Covell NH, Weissman EM, Schell B, McCorkle BH, Summerfelt WT, Weiden $\mathrm{PJ}$, et al. Distress with medication side effects among persons with severe mental illness. Adm Policy Ment Health (2007) 34 (5)435-442.

doi:10.1007/s10488-007-0131-1

2. van Westrhenen $\mathrm{R}$, Aitchison $\mathrm{KJ}$, Ingelman-Sundberg M, Jukić MM. Pharmacogenomics of Antidepressant and Antipsychotic Treatment: How Far Have We Got and Where Are We Going? Front Psychiatry (2020) 11 (March)1-11. doi:10.3389/fpsyt.2020.00094

3. Alshabeeb MA, Deneer VHM, Khan A, Asselbergs FW. Use of Pharmacogenetic Drugs by the Dutch Population. Front Genet (2019) 10 (July)1-9. doi:10.3389/fgene.2019.00567

4. Jarvis JP, Peter AP, Shaman JA. Consequences of CYP2D6Copy-number variation for pharmacogenomics in psychiatry. Front Psychiatry (2019) 10 (JUN)1-14. doi:10.3389/fpsyt.2019.00432

5. Ruaño G, Szarek BL, Villagra D, Gorowski K, Kocherla M, Seip RL, et al. Length of psychiatric hospitalization is correlated with CYP2D6 functional status in inpatients with major depressive disorder. Biomark Med (2013) 7 (3)429-439. doi:10.2217/bmm.13.16

6. Fleeman N, McLeod C, Bagust A, Beale S, Boland A, Dundar, Y, et al. The clinical effectiveness and cost-effectiveness of testing for cytochrome P450 polymorphisms in patients with schizophrenia treated with antipsychotics: a systematic review and economic evaluation. Health Technol Assess (Rockv) (2010) 14 (3)1-157. doi:10.3310/hta14030

7. Herbild L, Andersen SE, Werge T, Rasmussen HB, Jürgens G. Does pharmacogenetic testing for CYP450 2D6 and 2C19 among patients with diagnoses within the schizophrenic spectrum reduce treatment costs? Basic Clin Pharmacol Toxicol (2013) 113 (4)266-272. doi:10.1111/bcpt.12093

8. van Harten PN, Matroos GE, Hoek HW, Kahn RS. The prevalence of tardive dystonia, tardive dyskinesia, parkinsonism and akathisia. The Curaçao extrapyramidal syndromes study: I. Schizophr Res (1996) 19 (2-3)195-203. doi:10.1016/0920-9964(95)00096-8

9. de Caluwé L, van Buitenen N, Gelan PJ, Crunelle CL, Thomas R, Casseres S, et al. Prevalence of metabolic syndrome and its associated risk factors in an African-Caribbean population with severe mental illness. Psychiatry Res (2019) 281 (April)112558. doi:10.1016/j.psychres.2019.112558 
10. Naranjo M-EG, Rodrigues-Soares F, Peñas-Lledó EM, Tarazona-Santos E, Fariñas $\mathrm{H}$, Rodeiro I, et al. Interethnic Variability in CYP2D6, CYP2C9, and CYP2C19 Genes and Predicted Drug Metabolism Phenotypes Among 6060 Ibero- and Native Americans: RIBEF-CEIBA Consortium Report on Population Pharmacogenomics. Omi A J Integr Biol (2018) 22 (9)575-588. doi:10.1089/omi.2018.0114

11. Gaedigk A, Sangkuhl K, Whirl-Carrillo M, Klein T, Leeder JS. Prediction of CYP2D6 phenotype from genotype across world populations. Genet Med (2017) 19 (1)69-76. doi:10.1038/gim.2016.80

12. Nelson DR, Koymans L, Kamataki T, Stegeman JJ, Feyereisen R, Waxman DJ, et al. P450 superfamily: update on new sequences, gene mapping, accession numbers and nomenclature. Pharmacogenetics (1996) 6 (1)1-42. doi:10.1097/00008571-199602000-00002

13. Ingelman-Sundberg M. Genetic polymorphisms of cytochrome P450 2D6 (CYP2D6): clinical consequences, evolutionary aspects and functional diversity. Pharmacogenomics J (2005) 5 (1)6-13. doi:10.1038/sj.tpj.6500285

14. Shah RR, Smith RL. Addressing phenoconversion: the Achilles' heel of personalized medicine. Br J Clin Pharmacol (2014) 79 (2)222-240. doi:10.1111/bcp.12441

15. Shah RR, Smith RL. Inflammation-induced phenoconversion of polymorphic drug metabolizing enzymes: Hypothesis with implications for personalized medicine. Drug Metab Dispos (2014) 43 (3)400-410. doi:10.1124/dmd.114.061093

16. Shah RR. Pharmacogenetics and precision medicine: Is inflammation a covert threat to effective genotype-based therapy? Ther Adv Drug Saf (2017) 8 (9)267-272. doi:10.1177/2042098617712657

17. Berm E, Kok R, Hak E, Wilffert B. Relation between CYP2D6 genotype, phenotype and therapeutic drug concentrations among nortriptyline and venlafaxine users in old age psychiatry. Pharmacopsychiatry (2016) 49 (05)186-190. doi:10.1055/s-0042-105443

18. Preskorn SH, Kane CP, Lobello K, Nichols Al, Fayyad R, Buckley G, et al. Cytochrome $\mathrm{P} 4502 \mathrm{D} 6$ phenoconversion is common in patients being treated for depression. J Clin Psychiatry (2013) 74 (06)614-621. doi:10.4088/JCP.12m07807

19. Preskorn SH. Prediction of individual response to antidepressants and antipsychotics: an integrated concept. Dialogues Clin Neurosci (2014) 16545- 
554. Available at: http://www.ncbi.nlm.nih.gov/pubmed/4336923

20. de Leon J, Susce MT, Pan R-M, Fairchild M, Koch WH, Wedlund PJ. The CYP2D6 Poor Metabolizer phenotype may be associated with risperidone adverse drug reactions and discontinuation. J Clin Psychiatry (2005) 66 (01)15-27. doi:10.4088/JCP.v66n0103

21. Patsopoulos NA, Ntzani EE, Zintzaras E, loannidis JPA. CYP2D6 polymorphisms and the risk of tardive dyskinesia in schizophrenia: a metaanalysis. Pharmacogenet Genomics (2005) 15 (3)151-158. doi:10.1097/01213011-200503000-00003

22. Brockmöller J, Kirchheiner J, Schmider J, Walter S, Sachse C, Mulleroerlinghausen $\mathrm{B}$, et al. The impact of the polymorphism on haloperidol pharmacokinetics and on the outcome of haloperidol treatment. Clin Pharmacol Ther (2002) 72 (4)438-452. doi:10.1067/mcp.2002.127494

23. Lisbeth P, Vincent $H$, Kristof M, Bernard S, Manuel M, Hugo N. Genotype and co-medication dependent CYP2D6 metabolic activity: effects on serum concentrations of aripiprazole, haloperidol, risperidone, paliperidone and zuclopenthixol. Eur J Clin Pharmacol (2016) 72 (2)175-184. doi:10.1007/s00228-015-1965-1

24. Schenk PW, van Vliet $M$, Mathot $R$ a a, van Gelder $T$, Vulto a $G$, van Fessem $\mathrm{M}$ a C, et al. The CYP2C19*17 genotype is associated with lower imipramine plasma concentrations in a large group of depressed patients. Pharmacogenomics J (2010) 10 (3)219-25. doi:10.1038/tpj.2009.50

25. Kawanishi C, Lundgren S, Ågren $\mathrm{H}$, Bertilsson L. Increased incidence of CYP2D6 gene duplication in patients with persistent mood disorders: ultrarapid metabolism of antidepressants as a cause of nonresponse. A pilot study. Eur J Clin Pharmacol (2004) 59 (11)803-807. doi:10.1007/s00228-0030701-4

26. Kirchheiner J, Bertilsson L, Bruus H, Wolff a, Roots I, Bauer M. Individualized medicine - implementation of pharmacogenetic diagnostics in antidepressant drug treatment of major depressive disorders. Pharmacopsychiatry (2003) 36 Suppl 3 (Ccm)S235-43. doi:10.1055/s-2003-45136

27. Fleeman N, Dundar Y, Dickson R, Jorgensen A, Pushpakom S, Mcleod C. Cytochrome P450 testing for prescribing antipsychotics in adults with schizophrenia: systematic review and meta-analyses. Pharmacogenomics J (2011) 111-14. doi:10.1038/tpj.2010.73

28. Ingelman-Sundberg M. Pharmacogenetics of cytochrome P450 and its 
applications in drug therapy: the past, present and future. TRENDS Pharmacol Sci (2004) 25 (4)193-200. doi:10.1016/j.tips.2004.02.007

29. Weide J van der, Hinrichs JWJ. The influence of cytochrome P450 pharmacogenetics on disposition of common antidepressant and antipsychotic medications. Clin Biochem Rev (2006) 27 (1)17-25. Available at: http://www.pubmedcentral.nih.gov/articlerender.fcgi?artid=1390790\&tool= pmcentrez\&rendertype $=$ abstract

30. Arranz MJ, de Leon J. Pharmacogenetics and pharmacogenomics of schizophrenia: a review of last decade of research. Mol Psychiatry (2007) 12 (8)707-47. doi:10.1038/sj.mp.4002009

31. Weide J Van Der, Steijns LSW. Cytochrome P450 enzyme system: genetic polymorphisms and impact on clinical pharmacology. Ann Clin Biochem (1999) 36722-729.

32. Kirchheiner J, Nickchen K, Bauer M, Wong ML, Licinio J, Roots I, et al. Pharmacogenetics of antidepressants and antipsychotics: the contribution of allelic variations to the phenotype of drug response. Mol Psychiatry (2004) 9 (5)442-473. doi:10.1038/sj.mp.4001494

33. Caudle KE, Dunnenberger HM, Freimuth RR, Peterson JF, Burlison JD, WhirlCarrillo $\mathrm{M}$, et al. Standardizing terms for clinical pharmacogenetic test results: Consensus terms from the Clinical Pharmacogenetics Implementation Consortium (CPIC). Genet Med (2017) 19 (2)215-223. doi:10.1038/gim.2016.87

34. Caudle KE, Sangkuhl K, Whirl-Carrillo M, Swen JJ, Haidar CE, Klein TE, et al. Standardizing CYP 2D6 Genotype to Phenotype Translation: Consensus Recommendations from the Clinical Pharmacogenetics Implementation Consortium and Dutch Pharmacogenetics Working Group. Clin TransI Sci (2019)1-9. doi:10.1111/cts.12692

35. Gonzales FJ, Skoda RC, Kimura S, Gelboin H V, Hardwick JP, Meyer UA. Charcterization of the common genetic defect in humans deficient in debrisoquine metabolism. Nature (1988) 331 (4)442-446.

36. Ingelman-Sundberg M, Oscarson M, McLellan RA. Polymorphic human cytochrome P450 enzymes: an opportunity for individualized drug treatment. Trends Pharmacol Sci (1999) 20 (8)342-349. doi:10.1016/S01656147(99)01363-2

37. Eichelbaum M, Baur M, Dengler H, Osikowska-Evers B, Tieves G, Zekorn C, et al. Chromosomal assignment of human cytochrome $P-450$ 
(debrisoquine/sparteine type) to chromosome 22. Br J Clin Pharmacol (1987) 23 (4)455-458. doi:10.1111/j.1365-2125.1987.tb03075.x

38. Nofziger C, Turner AJ, Sangkuhl K, Whirl-Carrillo M, Agúndez JAG, Black JL, et al. PharmVar GeneFocus: CYP2D6. Clin Pharmacol Ther (2020) 107 (1)154170. doi: $10.1002 /$ cpt.1643

39. Fleischhacker W, Meise U, Günther V, Kurz M. Compliance with antipsychotic drug treatment: influence of side effects. Acta Psychiatr Scand (1994) 382115 .

40. de Haan L, Lavalaye J, van Bruggen $\mathrm{M}$, van Nimwegen L, Booij J, van Amelsvoort T, et al. Subjective experience and dopamine D2 receptor occupancy in patients treated with antipsychotics: clinical implications. Can J Psychiatry (2004) 49 (5)290-296. doi:10.1177/070674370404900503

41. Kapur S, Zipursky R, Jones C, Remington G, Houle S. Relationship between dopamine D2 occupancy, occupancy, clinical response, and side effects: $A$ double-blind PET study of first-episode schizophrenia. Am J Psychiatry (2000) 157 (4)514-520. doi:10.1176/appi.ajp.157.4.514

42. Chou WH, Yan FX, de Leon J, Barnhill J, Rogers T, Cronin M, et al. Extension of a pilot study: impact from the cytochrome P450 2D6 polymorphism on outcome and costs associated with severe mental illness. J Clin Psychopharmacol (2000) 20 (2)246-51. Available at: http://www.ncbi.nlm.nih.gov/pubmed/10770465

43. Arranz MJ, Gonzalez-Rodriguez A, Perez-Blanco J, Penadés R, Gutierrez B, Ibañez $\mathrm{L}$, et al. A pharmacogenetic intervention for the improvement of the safety profile of antipsychotic treatments. Transl Psychiatry (2019) 9 (1)177. doi:10.1038/s41398-019-0511-9

44. Swen JJ, Nijenhuis M, de Boer A, Grandia L, Maitland-van der Zee AH, Mulder $\mathrm{H}$, et al. Pharmacogenetics: from bench to byte-an update of guidelines. Clin Pharmacol Ther (2011) 89 (5)662-673. doi:10.1038/clpt.2011.34

45. Stingl JC, Brockmöller J, Viviani R. Genetic variability of drug-metabolizing enzymes: the dual impact on psychiatric therapy and regulation of brain function. Mol Psychiatry (2012) (May 2012) doi:10.1038/mp.2012.42

46. Hicks JK, Swen JJ, Thorn CF, Sangkuhl K, Kharasch ED, Ellingrod VL, et al. Clinical pharmacogenetics implementation consortium guideline for CYP2D6 and CYP2C19 genotypes and dosing of tricyclic antidepressants. Clin Pharmacol Ther (2013) 93 (5)402-408. doi:10.1038/clpt.2013.2 
47. Hicks JK, Bishop J, Sangkuhl K, Müller D, Ji Y, Leckband S, et al. Clinical pharmacogenetics implementation consortium (CPIC) guideline for CYP2D6 and CYP2C19 genotypes and dosing of selective serotonin reuptake inhibitors. Clin Pharmacol Ther (2015) 98 (2)127-134. doi:10.1002/cpt.147

48. Gray IC, Nobile C, Muresu R, Ford S, Spurr NK. A 2.4-megabase physical map spanning the CYP2C gene cluster on chromosome 10q24. Genomics (1995) 28 (2)328-332. doi:10.1006/geno.1995.1149

49. Vos A De, Weide J Van Der, Loovers H. Association between CYP2C19* 17 and metabolism of amitriptyline, citalopram and clomipramine in Dutch hospitalized patients. Pharmacogenomics J (2010) 11 (5)359-367. doi:10.1038/tpj.2010.39

50. Hodgson K, Tansey K, Dernovšek MZ, Hauser J, Henigsberg N, Maier W, et al. Genetic differences in cytochrome P450 enzymes and antidepressant treatment response. J Psychopharmacol (2014) 28 (2)133-141. doi:10.1177/0269881113512041

51. Rudberg I, Mohebi B, Hermann M, Refsum H, Molden E. Impact of the Ultrarapid CYP2C19*17 Allele on Serum Concentration of Escitalopram in Psychiatric Patients. (2008) 83 (2)322-327. doi:10.1038/sj.clpt.6 100291

52. Matchar DB, Thakur ME, Grossman I, McCrory DC, Orlando L a, Steffens DC, et al. Testing for Cytochrome P450 Polymorphisms in Adults With NonPsychotic Depression Treated With Selective Serotonin Reuptake Inhibitors (SSRIs). Agency Healthc Res Qual (2007) (146)1-77.

53. Shelton RC, Parikh S V., Law RA, Rothschild AJ, Thase ME, Dunlop BW, et al. Combinatorial Pharmacogenomic Algorithm is Predictive of Citalopram and Escitalopram Metabolism in Patients with Major Depressive Disorder.

Psychiatry Res (2020) 290 (December 2019)113017. doi:10.1016/j.psychres.2020.113017

54. Hall-Flavin DK, Winner JG, Allen JD, Carhart JM, Proctor B, Snyder KA, et al. Utility of integrated pharmacogenomic testing to support the treatment of major depressive disorder in a psychiatric outpatient setting. Pharmacogenet Genomics (2013) 23 (10)535-548. doi:10.1097/FPC.0b013e3283649b9a

55. Hall-Flavin DK, Winner JG, Allen JD, Jordan JJ, Nesheim RS, Snyder KA, et al. Using a pharmacogenomic algorithm to guide the treatment of depression. Transl Psychiatry (2012) 2 (10)e172-e172. doi:10.1038/tp.2012.99

56. Greden JF, Parikh S V., Rothschild AJ, Thase ME, Dunlop BW, DeBattista C, et al. Impact of pharmacogenomics on clinical outcomes in major depressive 
disorder in the GUIDED trial: $A$ large, patient- and rater-blinded, randomized, controlled study. J Psychiatr Res (2019) 111 (November 2018)59-67. doi:10.1016/j.jpsychires.2019.01.003

57. Bradford LD. CYP2D6 allele frequency in European Caucasians, Asians, Africans and their descendants. Pharmacogenomics (2002) 3 (2)229-43. doi:10.1517/14622416.3.2.229

58. Ingelman-Sundberg M. Genetic polymorphisms of cytochrome P450 2D6 (CYP2D6): clinical consequences, evolutionary aspects and functional diversity. Pharmacogenomics J (2005) 5 (1)6-13. doi:10.1038/sj.tpj.6500285

59. Céspedes-Garro C, Naranjo M-EG, Rodrigues-Soares F, LLerena A, Duconge J, Montané-Jaime LK, et al. Pharmacogenetic research activity in Central America and the Caribbean: a systematic review. Pharmacogenomics (2016) 17 (15)1707-1724. doi:10.2217/pgs-2016-0053

60. Moreno-Estrada A, Gravel S, Zakharia F, McCauley JL, Byrnes JK, Gignoux CR, et al. Reconstructing the population genetic history of the Caribbean. PLoS Genet (2013) 9 (11)e1003925. doi:10.1371/journal.pgen.1003925

61. Central Bureau of Statistics Curaçao. General Facts Curaçao. Available at: http://www.cbs.cw. (2020)

62. Centraal Bureau voor de Statistiek Den Haag: Bevolking; geslacht, leeftijd generatie en migratieachtergrond.

https://opendata.cbs.nl/statline/\#/CBS/nl/dataset/37325/table?fromstatweb. (2020)

63. Veling W, Selten J-P, Veen N, Laan W, Blom JD, Hoek HW. Incidence of schizophrenia among ethnic minorities in the Netherlands: a four-year firstcontact study. Schizophr Res (2006) 86 (1-3)189-93.

doi:10.1016/j.schres.2006.06.010

64. Vinkers DJ, Barendregt M, de Beurs E, Hoek HW, Rinne TH. Etnische verschillen tussen pro Justitia gerapporteerde verdachten. Tijdschr Psychiatr (2011) 53 (11)801-811.

65. Harten PN Van, Ph D, Hoek HW, Matroos GE, Os J Van. Incidence of Tardive Dyskinesia and Tardive Dystonia in African Caribbean Patients on Long-Term Antipsychotic Treatment: The Curaçao Extrapyramidal Syndromes Study V. (2006)1921-1928.

66. Mentzel CL, Bakker PR, van Os J, Drukker M, Matroos GE, Hoek HW, et al. Effect of Antipsychotic Type and Dose Changes on Tardive Dyskinesia and Parkinsonism Severity in Patients With a Serious Mental Illness. J Clin 
Psychiatry (2017) 78 (3)e279-e285. doi:10.4088/JCP.16m11049

67. Llerena A, Dorado P, Peñas-Lledó EM, Cáceres MC, De la Rubia A. Low frequency of CYP2D6 poor metabolizers among schizophrenia patients. Pharmacogenomics J (2007) 7 (6)408-10. doi:10.1038/sj.tpj.6500439

68. Thümmler S, Dor E, David R, Leali G, Battista M, David A, et al. Pharmacoresistant severe mental health disorders in children and adolescents: Functional abnormalities of cytochrome P450 2D6. Front Psychiatry (2018) 9 (JAN)1-5. doi:10.3389/fpsyt.2018.00002

69. West JC, Wilk JE, Olfson M, Rae DS, Marcus S, Narrow WE, et al. Patterns and quality of treatment for patients with schizophrenia in routine psychiatric practice. Psychiatr Serv (2005) 56 (3)283-291. doi:10.1176/appi.ps.56.3.283

70. Wullschleger A, Khazaal Y, Heinze M. Editorial: New models of care for patients with severe mental illness-Bridging in- and outpatients. Front Psychiatry (2018) 9 (January)9-10. doi:10.3389/fpsyt.2018.00003

71. van Harten PN, Hoek HW, Matroos GE, Koeter M, Kahn RS. The interrelationships of tardive dyskinesia, parkinsonism, akathisia, and tardive dystonia: the Curacao Extrapyramidal Syndromes Study II. Schizophr Res (1997) 26235-242.

72. Fan M, Bousman CA. Estimating the Potential Impact of CYP2C19 and CYP2D6 Genetic Testing on Protocol-Based Care for Depression in Canada and the United States. Mol Neuropsychiatry (2019) 5 (1)27-33. doi:10.1159/000504253

73. Center for Behavioral Health Statistics and Quality. 2016 National survey on drug use and health: Methodological summary and definitions. Rockville, MD: Substance Abuse and Mental Health Services Administration. (2017) (9) Available at: www.samhsa.gov/data/population-data-nsduh

74. Habtamu K, Alem A, Medhin G, Fekadu A, Prince M, Hanlon C. Development and validation of a contextual measure of functioning for people living with severe mental disorders in rural Africa. BMC Psychiatry (2016) 16 (1)311. doi:10.1186/s12888-016-1022-3

75. Habtamu K, Alem A, Medhin G, Fekadu A, Dewey M, Prince M, et al. Validation of the World Health Organization Disability Assessment Schedule in people with severe mental disorders in rural Ethiopia. Health Qual Life Outcomes (2017) 15 (1)64. doi:10.1186/s12955-017-0647-3

76. Chopra PK, Couper JW, Herrman H. The assessment of patients with longterm psychotic disorders: Application of the WHO Disability Assessment 
Schedule II. Aust N Z J Psychiatry (2004) 38 (9)753-759. doi:10.1080/j.14401614.2004.01448.x

77. Burke W. Clinical Validity and Clinical Utility of Genetic Tests. Curr Protoc Hum Genet (2009) 81 (9)1-14. doi:10.1002/0471142905.hg0915s60

78. Bhugra D, Gupta S, Bhui K, Craig T, Dogra N, Ingleby JD, et al. WPA guidance on mental health and mental health care in migrants. World Psychiatry (2011) 10 (1)2-10. Available at: http://www.ncbi.nlm.nih.gov/pubmed/21379345

79. Perlis RH. Abandoning personalization to get to precision in the pharmacotherapy of depression. World Psychiatry (2016) 15 (3)228-235. doi:10.1002/wps.20345

80. Kishimoto T, Hagi K, Nitta M, Kane JM, Correll CU. Long-term effectiveness of oral second-generation antipsychotics in patients with schizophrenia and related disorders: a systematic review and meta-analysis of direct head-tohead comparisons. World Psychiatry (2019) 18 (2)208-224. doi:10.1002/wps.20632

81. Aklillu E, Persson I, Bertilsson L, Johansson I, Rodrigues F, IngelmanSundberg M. Frequent distribution of ultrarapid metabolizers of debrisoquine in an Ethiopian population carrying duplicated and multiduplicated functional CYP2D6 alleles. J Pharmacol Exp Ther (1996) 278 (1)441-446.

82. Fricke-Galindo I, Céspedes-Garro C, Rodrigues-Soares F, Naranjo MEG, Delgado Á, de Andrés F, et al. Interethnic variation of CYP2C19 alleles, 'predicted' phenotypes and 'measured' metabolic phenotypes across world populations. Pharmacogenomics J (2016) 16 (2)113-123. doi:10.1038/tpj.2015.70

83. Cai W-M, Nikoloff DM, Pan R-M, de Leon J, Fanti P, Fairchild M, et al. CYP2D6 genetic variation in healthy adults and psychiatric African-American subjects: implications for clinical practice and genetic testing. Pharmacogenomics J (2006) 6 (5)343-350. doi:10.1038/sj.tpj.6500378

84. Gaedigk A, Bhathena A, Ndjountché L, Pearce RE, Abdel-Rahman SM, Alander SW, et al. Identification and characterization of novel sequence variations in the cytochrome P4502D6 (CYP2D6) gene in African Americans. Pharmacogenomics J (2005) 5 (3)173-182. doi:10.1038/sj.tpj.6500305

85. Swen JJ, Wilting I, Goede A de, Grandia L, Mulder H, Touw D, et al. Pharmacogenetics: From Bench to Byte. Clin Pharmacol Ther (2008) 83 (5)781-787. doi:10.1038/sj.clpt.6100507 
86. LLerena A, Naranjo MEG, Rodrigues-Soares F, Penas-LLedó EM, Fariñas H, Tarazona-Santos E. Interethnic variability of CYP2D6 alleles and of predicted and measured metabolic phenotypes across world populations. Expert Opin Drug Metab Toxicol (2014) 10 (11)1569-1583. doi:10.1517/17425255.2014.964204

87. Rosenblat JD, Lee Y, McIntyre RS. Does Pharmacogenomic Testing Improve Clinical Outcomes for Major Depressive Disorder? J Clin Psychiatry (2017) 78 (06)720-729. doi:10.4088/JCP.15r10583

88. Koopmans AB, Vinkers DJ, Poulina IT, Gelan PJA, van Schaik RHN, Hoek HW, et al. No effect of dose adjustment to the CYP2D6 genotype in patients with severe mental illness. Front Psychiatry (2018) 9 (August) doi:10.3389/fpsyt.2018.00349

89. Borden BA, Galecki P, Wellmann R, Danahey K, Lee SM, Patrick-Miller L, et al. Assessment of provider-perceived barriers to clinical use of pharmacogenomics during participation in an institutional implementation study. Pharmacogenet Genomics (2019) 29 (2)31-38. doi:10.1097/FPC.0000000000000362

90. Nurnberger Jl, Austin J, Berrettini WH, Besterman AD, DeLisi LE, Grice DE, et al. What Should a Psychiatrist Know About Genetics? J Clin Psychiatry (2018) 80 (1)e144-e151. doi:10.4088/JCP.17nr12046

91. Salm M, Abbate K, Appelbaum P, Ottman R, Chung W, Marder K, et al. Use of Genetic Tests among Neurologists and Psychiatrists: Knowledge, Attitudes, Behaviors, and Needs for Training. J Genet Couns (2014) 23 (2)156-163. doi:10.1007/s10897-013-9624-0

92. Simoons M, Mulder H, Schoevers RA, Ruhé HG, van Roon EN. Availability of CYP2D6 genotyping results in general practitioner and community pharmacy medical records. Pharmacogenomics (2017) 18 (9)843-851. doi:10.2217/pgs2017-0043

93. Hamilton SP. The Promise of Psychiatric Pharmacogenomics. Biol Psychiatry (2015) 77 (1)29-35. doi:10.1016/j.biopsych.2014.09.009

94. Spina $\mathrm{E}$, de Leon J. Clinical applications of CYP genotyping in psychiatry. J Neural Transm (2015) 122 (1)5-28. doi:10.1007/s00702-014-1300-5 
95. Almoguera B, Riveiro-alvarez R, Lopez-castroman J, Dorado P, Abad-santos $\mathrm{F}$, Baca-garcı E, et al. CYP2D6 poor metabolizer status might be associated with better response to risperidone treatment of Pharmacogenetics Research in Schizophrenia. Pharmacogenet Genomics (2013) 23 (11)627-630. doi:10.1097/FPC.0b013e3283659a94

96. Kaur G, Gupta D, Chavan BS, Sinhmar V, Prasad R, Tripathi A, et al. Identification of genetic correlates of response to Risperidone: Findings of a multicentric schizophrenia study from India. Asian J Psychiatr (2017) 29174182. doi:10.1016/j.ajp.2017.07.026

97. Moher D, Liberati A, Tetzlaff J, Altman DG. Preferred Reporting Items for Systematic Reviews and Meta-Analyses: The PRISMA Statement. PLoS Med (2009) 6 (7)e1000097. doi:10.1371/journal.pmed.1000097

98. Liberati A, Altman DG, Tetzlaff J, Mulrow C, Gøtzsche PC, loannidis JP a, et al. The PRISMA statement for reporting systematic reviews and meta-analyses of studies that evaluate health care interventions: explanation and elaboration. PLoS Med (2009) 6 (7)e1000100. doi:10.1371/journal.pmed.1000100

99. Gaedigk A, Sangkuhl K, Whirl-Carrillo M, Twist GP, Klein TE, Miller NA. The Evolution of PharmVar. Clin Pharmacol Ther (2019) 105 (1)cpt.1275. doi:10.1002/cpt.1275

100. Gaedigk A, Ingelman-Sundberg M, Miller NA, Leeder JS, Whirl-Carrillo M, Klein TE. The Pharmacogene Variation (PharmVar) Consortium: Incorporation of the Human Cytochrome P450 ( CYP) Allele Nomenclature Database. Clin Pharmacol Ther (2018) 103 (3)399-401. doi:10.1002/cpt.910

101. Rosenberg NA, Mahajan S, Ramachandran S, Zhao C, Pritchard JK, Feldman MW. Clines, clusters, and the effect of study design on the inference of human population structure. PLoS Genet (2005) 1 (6)0660-0671. doi:10.1371 /journal.pgen.0010070

102. Suarez-Kurtz G. Pharmacogenomics in admixed populations. Trends Pharmacol Sci (2005) 26 (4)196-201. doi:10.1016/j.tips.2005.02.008

103. Parra FC, Amado RC, Lambertucci JR, Rocha J, Antunes CM, Pena SDJ. Color and genomic ancestry in Brazilians. Proc Natl Acad Sci (2003) 100 (1)177182. doi: $10.1073 /$ pnas. 0126614100

104. Sistonen J, Sajantila A, Lao O, Corander J, Barbujani G, Fuselli S. CYP2D6 worldwide genetic variation shows high frequency of altered activity variants and no continental structure. Pharmacogenet Genomics (2007) 17 (2)93-101.

105. Wendt FR, Pathak G, Sajantila A, Chakraborty R, Budowle B. Global genetic 
variation of select opiate metabolism genes in self-reported healthy individuals. Pharmacogenomics J (2018) 18 (2)281-294.

doi:10.1038/tpj.2017.13

106. Rasmussen JO, Christensen M, Svendsen JM, Skausig O, Hansen EL, Nielsen $\mathrm{K}$ a. CYP2D6 gene test in psychiatric patients and healthy volunteers. Scand J Clin Lab Invest (2006) 66 (2)129-136. doi:10.1080/00365510500469702

107. Vicente J, González-Andrade F, Soriano A, Fanlo A, Martínez-Jarreta B, Sinués B. Genetic polymorphisms of CYP2C8, CYP2C9 and CYP2C19 in Ecuadorian Mestizo and Spaniard populations: a comparative study. Mol Biol Rep (2014) 41 (3)1267-1272. doi:10.1007/s11033-013-2971-y

108. Mirzaev KB, Sychev DA, Ryzhikova KA, Konova OD, Mammaev SN, Gafurov DM, et al. Genetic Polymorphisms of Cytochrome P450 Enzymes and Transport Proteins in a Russian Population and Three Ethnic Groups of Dagestan. Genet Test Mol Biomarkers (2017) 21 (12)747-753. doi:10.1089/gtmb.2017.0036

109. Payan M, Tajik N, Rouini MR, Ghahremani MH. Genotype and allele frequency of CYP2C19*17 in a healthy Iranian population. Med J Islam Repub Iran (2015) 29 (1)269. Available at: http://www.ncbi.nlm.nih.gov/pubmed/26793660

110. Riaz S, Muhammad Din S, Usman Tareen M, Tariq F, Latif Y, Siddiqi S, et al. Genetic Polymorphism of CYP2C19 in Pakistani Population. Iran J Pharm Res (2019) 18 (2)1097-1102. doi:10.22037/ijpr.2019.1100644

111. Deshpande N, V. S, V. V. RK, H. V. V. M, M. S, Banerjee R, et al. Rapid and ultra-rapid metabolizers with CYP2C19 *17 polymorphism do not respond to standard therapy with proton pump inhibitors. Meta Gene (2016) 9 (8)159164. doi:10.1016/j.mgene.2016.06.004

112. Ohkubo T, Suno M, Sugawara K, Motomuro S. Graphic Roots of CYP2C19 genetic polymorphism in Japanese population (preliminary report). Int Congr Ser (2002) 124463-67.

113. Zuo J, Xia D, Jia L, Guo T. Genetic polymorphisms of drug-metabolizing phase I enzymes CYP3A4, CYP2C9, CYP2C19 and CYP2D6 in Han, Uighur, Hui and Mongolian Chinese populations. Pharmazie (2011) 67 (7)639-644. doi:10.1691/ph.2012.1735

114. Yin S-J, Ni Y-B, Wang S-M, Wang X, Lou Y-Q, Zhang G-L. Differences in genotype and allele frequency distributions of polymorphic drug metabolizing enzymes CYP2C19 and CYP2D6 in mainland Chinese Mongolian, Hui and 
Han populations. J Clin Pharm Ther (2012) 37 (3)364-369.

doi:10.1111/j.1365-2710.2011.01298.x

115. Shalia KK, Shah VK, Pawar P, Divekar SS, Payannavar S. Polymorphisms of MDR1, CYP2C19 and P2Y12 genes in Indian population: Effects on clopidogrel response. Indian Heart J (2013) 65 (2)158-167. doi:10.1016/j.ihj.2013.02.012

116. Anichavezhi D, Chakradhara Rao US, Shewade DG, Krishnamoorthy R, Adithan C. Distribution of CYP2C19*17 allele and genotypes in an Indian population. J Clin Pharm Ther (2012) 37 (3)313-318. doi:10.1111/j.13652710.2011.01294.x

117. Afsar NA, Bruckmueller H, Werk AN, Nisar MK, Ahmad HR, Cascorbi I. Implications of genetic variation of common Drug Metabolizing Enzymes and ABC Transporters among the Pakistani Population. Sci Rep (2019) 9 (1)7323. doi:10.1038/s41598-019-43736-z

118. Riaz S, Mansoor A, Siddiqi S, Tareen MU, Batool A, Sultan A. Association of CYP2C19 * 2 and * 17 genetic variants with hypertension in Pakistani population. Trop J Pharm Res (2019) 18 (April)851-855.

doi:10.4314/tjpr.v18i4.24

119. Hashemizadeh Z, Malek-Hosseini SA, Badiee P. Prevalence of CYP2C19 Genetic Polymorphism among Normal People and Patients with Hepatic Diseases. Int J organ Transplant Med (2018) 9 (1)27-33. Available at: http://journals.aace.com/doi/abs/10.4158/EP12130.OR

120. Dehbozorgi $M$, Kamalidehghan $B$, Hosseini I, Dehghanfard Z, Sangtarash $M$, Firoozi M, et al. Prevalence of the CYP2C19*2 (681 G>A), *3 (636 G>A) and ${ }^{*} 17(-806>T)$ alleles among an Iranian population of different ethnicities. Mol Med Rep (2018) 17 (3)4195-4202. doi:10.3892/mmr.2018.8377

121. Ortega-Vázquez $A$, Dorado $P$, Fricke-Galindo I, Jung-Cook $H$, MonroyJaramillo N, Martínez-Juárez IE, et al. CYP2C9, CYP2C19, ABCB1 genetic polymorphisms and phenytoin plasma concentrations in Mexican-Mestizo patients with epilepsy. Pharmacogenomics J (2016) 16 (3)286-292. doi:10.1038/tpj.2015.45

122. de Andrés F, Sosa-Macías M, Ramos BPL, Naranjo M-EG, LLerena A. CYP450 Genotype/Phenotype Concordance in Mexican Amerindian Indigenous Populations-Where to from Here for Global Precision Medicine? Omi A J Integr Biol (2017) 21 (9)509-519. doi:10.1089/omi.2017.0101

123. Favela-Mendoza AF, Martínez-Cortes G, Romero-Prado MM, Romero-Tejeda $\mathrm{EM}$, Islas-Carbajal MC, Sosa-Macias M, et al. Correspondence between the 
CYP2C19 and CYP3A4 genotypes with the inferred metabolizer phenotype by omeprazole administration in Mexican healthy children. J Clin Pharm Ther (2018) 43 (5)656-663. doi:10.1111/jcpt.12699

124. Céspedes-Garro C, Rodrigues-Soares F, Jiménez-Arce G, G. Naranjo M-E, Tarazona-Santos $\mathrm{E}$, Fariñas $\mathrm{H}$, et al. Relevance of the ancestry for the variability of the Drug-Metabolizing Enzymes CYP2C9, CYP2C19 and CYP2D6 polymorphisms in a multiethnic Costa Rican population. Rev Biol Trop (2016) 64 (3) doi:10.15517/rbt.v64i3.20901

125. Ingelman-Sundberg M, Sim SC, Gomez A, Rodriguez-Antona C. Influence of cytochrome $P 450$ polymorphisms on drug therapies: pharmacogenetic, pharmacoepigenetic and clinical aspects. Pharmacol Ther (2007) 116 (3)496526. doi:10.1016/j.pharmthera.2007.09.004

126. Huddart R, Fohner AE, Whirl-Carrillo $M$, Wojcik GL, Gignoux CR, Popejoy AB, et al. Standardized Biogeographic Grouping System for Annotating Populations in Pharmacogenetic Research. Clin Pharmacol Ther (2019) 105 (5)1256-1262. doi:10.1002/cpt.1322

127. Zhang F, Finkelstein J. Inconsistency in race and ethnic classification in pharmacogenetics studies and its potential clinical implications. Pharmgenomics Pers Med (2019) Volume 12107-123. doi:10.2147/PGPM.S207449

128. Riccardi LN, Lanzellotto R, Luiselli D, Ceccardi S, Falconi M, Bini C, et al. CYP2D6 Genotyping in Natives and Immigrants from the Emilia-Romagna Region (Italy). Genet Test Mol Biomarkers (2011) 15 (11)801-806. doi:10.1089/gtmb.2010.0221

129. Dodgen TM, Hochfeld WE, Fickl H, Asfaha SM, Durandt C, Rheeder P, et al. Introduction of the AmpliChip CYP450 Test to a South African cohort: a platform comparative prospective cohort study. BMC Med Genet (2013) 14 (1)20. doi:10.1186/1471-2350-14-20

130. Shah RR, Gaedigk A. Precision medicine: does ethnicity information complement genotype-based prescribing decisions? Ther Adv Drug Saf (2018) 9 (1)45-62. doi:10.1177/2042098617743393

131. de Andrés F, Terán S, Hernández F, Terán E, LLerena A. To Genotype or Phenotype for Personalized Medicine? CYP450 Drug Metabolizing Enzyme Genotype-Phenotype Concordance and Discordance in the Ecuadorian Population. Omi A J Integr Biol (2016) 20 (12)699-710. doi:10.1089/omi.2016.0148 
132. Torres US, Portela-Oliveira E, Borgwardt S, Busatto GF. Structural brain changes associated with antipsychotic treatment in schizophrenia as revealed by voxel-based morphometric MRI: an activation likelihood estimation metaanalysis. BMC Psychiatry (2013) 13 (1)342. doi:10.1186/1471-244X-13-342

133. Zutshi D, Cloud LJ, Factor SA. Tardive syndromes are rarely reversible after discontinuing dopamine receptor blocking agents: Experience from a university-based movement disorder clinic. Tremor Other Hyperkinet Mov (N Y) (2014) 41-9. doi:10.7916/D8MS3R8C

134. Gaedigk A, Simon S, Pearce R, Bradford L, Kennedy M, Leeder J. The CYP2D6 Activity Score: Translating Genotype Information into a Qualitative Measure of Phenotype. Clin Pharmacol Ther (2008) 83 (2)234-242. doi:10.1038/sj.clpt.6100406

135. Kirchheiner J, Meineke I, Müller G, Roots I, Brockmöller J. Contributions of CYP2D6, CYP2C9 and CYP2C19 to the biotransformation of E- and Z-doxepin in healthy volunteers. Pharmacogenetics (2002) 12 (7)571-580. doi:10.1097/00008571-200210000-00010

136. Chang M, Tybring G, Dahl M-L, Lindh JD. Impact of Cytochrome P450 2C19 Polymorphisms on Citalopram/Escitalopram Exposure: A Systematic Review and Meta-Analysis. Clin Pharmacokinet (2014) 53 (9)801-811. doi:10.1007/s40262-014-0162-1

137. Steimer W, Zöpf K, von Amelunxen S, Pfeiffer H, Bachofer J, Popp J, et al. Amitriptyline or Not, That Is the Question: Pharmacogenetic Testing of CYP2D6 and CYP2C19 Identifies Patients with Low or High Risk for Side Effects in Amitriptyline Therapy. Clin Chem (2005) 51 (2)376-385. doi:10.1373/clinchem.2004.041327

138. Laika B, Leucht S, Heres S, Steimer W. Intermediate metabolizer: increased side effects in psychoactive drug therapy. The key to cost-effectiveness of pretreatment CYP2D6 screening? Pharmacogenomics J (2009) 9 (6)395-403. doi:10.1038/tpj.2009.23

139. Hicks J, Sangkuhl K, Swen J, Ellingrod V, Müller D, Shimoda K, et al. Clinical pharmacogenetics implementation consortium guideline (CPIC) for CYP2D6 and CYP2C19 genotypes and dosing of tricyclic antidepressants: 2016 update. Clin Pharmacol Ther (2017) 102 (1)37-44. doi:10.1002/cpt.597

140. González I, Peñas-Lledó EM, Pérez B, Dorado P, Alvarez M, LLerena A. Relation between CYP2D 6 phenotype and genotype and personality in healthy volunteers. Pharmacogenomics (2008) 9 (7)833-40. doi:10.2217/14622416.9.7.833 
141. Babalola CP, Adejumo O, Bs DU, Ms ZX, Fimls AO, Mbbs TK, et al. Cytochrome P450 CYP2C19 genotypes in Nigerian sickle-cell disease patients and normal controls. Pharmacogenetics (2010) 35471-477. doi:10.1111/j.1365-2710.2009.01122.x

142. Barañska M, Dziankowska-bartkowiak B, Waszczykowska E, Rychlik-sych M, Skrêtkowicz J. Significance of genetic polymorphism of CYP2D6 in the pathogenesis of systemic sclerosis. Pharmacoglogical Reports (2012) 64336342.

143. Singh $M$, Khan A, Shah P, Shukla R, Khanna V, Parmar D. Polymorphism in environment responsive genes and association with Parkinson disease. Mol Cell Biochem (2008) 312131-138. doi:10.1007

144. Brown MA, Edwards S, Hoyle E, Campbell S, Laval S, Daly AK, et al. Polymorphisms of the CYP2D6 gene increase susceptibility to ankylosing spondylitis. Hum Mol Genet (2000) 9 (11)1563-1566.

145. Ladona M, Abildua R, Ladero J, Roman J, Plaza M, Agundez J, et al. CYP2D6 genotypes in Spanish women with breast cancer. Cancer Lett (1996) 9923-28.

146. Singh H, Lata S, Gangakhedkar RR. Prevalence of CYP2D6 * 4 1934G / A polymorphism in Western Indian HIV patients. J Pathol Microbiol Immunol (2018) 126842-851. doi:10.1111/apm.12893

147. Del Tredici AL, Malhotra A, Dedek M, Espin F, Roach D, Zhu G, et al. Frequency of CYP2D6 Alleles Including Structural Variants in the United States. Front Pharmacol (2018) 9 (APR) doi:10.3389/fphar.2018.00305

148. Griman P, Moran Y, Valero G, Loreto M, Borjas L, Chiurillo MA. CYP2D6 gene variants in urban/admixed and Amerindian populations of Venezuela: Pharmacogenetics and anthropological implications. Ann Hum Biol (2012) 39 (2)137-142. doi:10.3109/03014460.2012.656703

149. Yousef A-M, Bulatova NR, Newman W, Hakooz N, Ismail S, Qusa H, et al. Allele and genotype frequencies of the polymorphic cytochrome $P 450$ genes (CYP1A1, CYP3A4, CYP3A5, CYP2C9 and CYP2C19) in the Jordanian population. Mol Biol Rep (2012) 39 (10)9423-9433. doi:10.1007/s11033-0121807-5

150. Budd WT, Meyers G, Dilts JR, O' K, Hanlon NA, Woody JR, et al. Next generation sequencing reveals disparate population frequencies among cytochrome P450 genes: clinical pharmacogenomics of the CYP2 family. Int J Comput Biol Drug Des (2016) 9 (1/2)54. doi:10.1504/IJCBDD.2016.074984

151. Pratt VM, Zehnbauer B, Wilson JA, Baak R, Babic N, Bettinotti M, et al. 
Characterization of 107 Genomic DNA Reference Materials for CYP2D6, CYP2C19, CYP2C9, VKORC1, and UGT1A1. J Mol Diagnostics (2010) 12 (6)835-846. doi:10.2353/jmoldx.2010.100090

152. Banda $Y$, Kvale MN, Hoffmann TJ, Hesselson SE, Ranatunga D, Tang $\mathrm{H}$, et al. Characterizing Race/Ethnicity and Genetic Ancestry for 100,000 Subjects in the Genetic Epidemiology Research on Adult Health and Aging (GERA) Cohort. Genetics (2015) 200 (4)1285-1295. doi:10.1534/genetics.115.178616

153. Pratt VM, Del Tredici AL, Hachad H, Ji Y, Kalman L V., Scott SA, et al. Recommendations for clinical CYP2C19 Genotyping allele selection. J Mol Diagnostics (2018) 20 (3)269-276. doi:10.1016/j.jmoldx.2018.01.011

154. Weide J Van Der, Baalen-Benedek EH Van, Kootstra-Ros JE. Metabolic ratios of psychotropics as indication of cytochrome P450 2D6/2C19 genotype. Ther Drug Monit (2005) 27 (4)478-483.

155. Suzuki T, Mihara K, Nakamura A, Nagai G, Kagawa S, Nemoto K, et al. Effects of the CYP2D6*10 allele on the steady-state plasma concentrations of aripiprazole and its active metabolite, dehydroaripiprazole, in Japanese patients with schizophrenia. Ther Drug Monit (2011) 33 (1)21-4. doi:10.1097/FTD.0b013e3182031021

156. Hiemke C., Baumann P., Bergemann N., Arolsen B., Conca A., Dietmaier O., et al. AGNP consensus guidelines for therapeutic drug monitoring in psychiatry: Update 2011. Pharmacopsychiatry (2011) 44 (1)195-235.

doi:http://dx.doi.org/ 10.1055/s-0031-1286287

157. de Haan L, van Bruggen M, Lavalaye J, Booij J, Dingemans PMAJ, Linszen D. Subjective experience and $D 2$ receptor occupancy in patients with recentonset schizophrenia treated with low-dose olanzapine or haloperidol: a randomized, double-blind study. Am J Psychiatry (2003) 160 (2)303-309. doi:10.1176/appi.ajp.160.2.303

158. Nikoloff D, Shim J, Patten N, Fijal BA, Flockhart D, Yoon J, et al. Association between CYP2D6 genotype and tardive dyskinesia in Korean schizophrenics. Pharmacogenomics J (2002) 2400-407. doi:10.1038/sj.tpj.6500138

159. Kapitany T, Meszaros K, Lenzinger E, Schindler SD, Barnas C, Fuchs K, et al. Genetic polymorphisms for drug metabolism (CYP2D6) and tardive dyskinesia in schizophrenia. Schizophr Res (1998) 32 (2)101-106. doi:10.1016/S09209964(98)00038-3

160. Scordo MG, Spina E, Romeo P, Dahl M-L, Bertilsson L, Johansson I, et al. CYP2D6 genotype and antipsychotic-induced extrapyramidal side effects in 
schizophrenic patients. Eur J Clin Pharmacol (2000) 56 (9-10)679-683. doi:10.1007/s002280000222

161. Schillevoort I, de Boer A, van der Weide J, Steijns LSW, Roos RAC, Jansen $\mathrm{PAF}$, et al. Antipsychotic-induced extrapyramidal syndromes and cytochrome P450 2D6 genotype: a case-control study. Pharmacogenetics (2002) 12 (3)235-40. Available at: http://www.ncbi.nlm.nih.gov/pubmed/11927839 [Accessed December 11, 2014]

162. Hiroi T, Imaoka S, Funae Y. Dopamine formation from tyramine by CYP2D6. Biochem Biophys Res Commun (1998) 249 (3)838-843. doi:10.1006/bbrc.1998.9232

163. Llerena A, Edman G, Gobaleda J, Benitz J, Schalling D, Bertilsson L. Relationship between personality and debrisoquine hydroxylation capacity. Acta Psychiatr Scand (1993) 8723-28.

164. Chen CH, Hung CC, Wei FC, Koong FJ. Debrisoquine 4-hydroxylase (CYP2D6) genetic polymorphisms and susceptibility to schizophrenia in Chinese patients from Taiwan. Psychiatr Genet (2001) 11 (3)153-155. doi:10.1097/00041444200109000-00007

165. Dawson E, Powell JF, Nöthen MM, Crocq MA, Lanczik M, Körner J, et al. An association study of debrisoquine hydroxylase (CYP2D6) polymorphisms in schizophrenia. Psychiatr Genet (1994) 4 (4)215-8. doi:66680

166. Pirmohamed M, Wild MJ, Kitteringham NR, O'Brien K, Buchan IE, Back DJ, et al. Lack of association between schizophrenia and the CYP2D6 gene polymorphisms. Am J Med Genet (1996) 67 (2)236-237.

doi:10.1002/ajmg.1320670205

167. Jönsson EG, Dahl ML, Roh HK, Jerling M, Sedvall GC. Lack of association between debrisoquine 4-hydroxylase (CYP2D6) gene polymorphisms and schizophrenia. Psychiatr Genet (1998) 8 (1)25-8.

168. Daniels J, Williams J, Asherson P, McGuffin P, Owen M. No association between schizophrenia and polymorphisms within the genes for debrisoquine 4-hydroxylase (CYP2D6) and the dopamine transporter (DAT). Am J Med Genet (1995) 27 (60(1))85-7.

169. Dahl ML, Johansson I, Bertilsson L, Ingelman-Sundberg M, Sjöqvist F. Ultrarapid hydroxylation of debrisoquine in a Swedish population. Analysis of the molecular genetic basis. J Pharmacol Exp Ther (1995) 274 (1)516-520. 
170. Agúndez JAG, Ledesma MC, Ladero JM, Benítez J. Prevalence of CYP2D6 gene duplication and its repercussion on the oxidative phenotype in a white population. Clin Pharmacol Ther (1995) 57 (3)265-269.

171. Gaedigk A, Bradford LD, Marcucci K a, Leeder JS. Unique CYP2D6 activity distribution and genotype-phenotype discordance in black Americans. Clin Pharmacol Ther (2002) 72 (1)76-89. doi:10.1067/mcp.2002.125783

172. Albuquerque J, Ribeiro C, Naranjo MEG, Llerena A, Grazina M. Characterization of CYP2D6 genotypes and metabolic profiles in the Portuguese population: pharmacogenetic implications. Per Med (2013) 10 (7)709-718. doi:10.2217/pme.13.56

173. Miura J, Obua C, Abbo C, Kaneko S, Tateishi T. Cytochrome P450 2C19 genetic polymorphisms in Ugandans. Eur J Clin Pharmacol (2009) 65 (3)319320. doi:10.1007/s00228-008-0583-6

174. Ragia G, Arvanitidis KI, Tavridou A, Manolopoulos VG. Need for reassessment of reported CYP2C19 allele frequencies in various populations in view of CYP2C19*17 discovery: the case of Greece. Pharmacogenomics (2009) 10 (1)43-49. doi:10.2217/14622416.10.1.43

175. Loovers HM, van der Weide J. Implementation of CYP2D6 genotyping in psychiatry. Expert Opin Drug Metab Toxicol (2009) 5 (9)1065-77. doi:10.1517/17425250903081738

176. Crews KR, Gaedigk a, Dunnenberger HM, Klein TE, Shen DD, Callaghan JT, et al. Clinical Pharmacogenetics Implementation Consortium (CPIC) guidelines for codeine therapy in the context of cytochrome P450 2D6 (CYP2D6) genotype. Clin Pharmacol Ther (2012) 91 (2)321-6. doi:10.1038/clpt.2011.287

177. Raymond M, Rousset F. GENEPOP (version 1.2): population genetics software for exact tests and ecumenicism. J Hered (1995) 86248-249.

178. Rousset F. genepop'007: a complete re-implementation of the genepop software for Windows and Linux. Mol Ecol Resour (2008) 8 (1)103-106. doi:10.1111/j.1471-8286.2007.01931.x

179. Dalhuisen L, Donk R, Hoefte R, Steegh F. History of the Antilles Aruba, Bonaire, Curaçao, Saba, Sint-Eustatius, Sint-Maarten (Geschiedenis van de Antillen Aruba, Bonaire, Curaçao, Saba, Sint-Eustatius, Sint-Maarten). (2009).

180. Samer CF, Lorenzini KI, Rollason V, Daali Y, Desmeules JA. Applications of CYP450 testing in the clinical setting. Mol Diagnosis Ther (2013) 17 (3)165184. doi:10.1007/s40291-013-0028-5 
181. Scott SA, Sangkuhl K, Gardner EE, Stein CM, Hulot J, Johnson JA, et al. Supplemental material clinical pharmacogenetics implementation consortium (CPIC) guidelines for cytochrome P450-2C19 (CYP2C19) genotype and clopidogrel therapy. Clin Pharmacol Ther (2011) 90 (2)1-11.

182. Inaba T, Jorge L, Arias T. Mephenytoin hydroxylation in the Cuna Amerindians of Panama. Br J Clin Pharmacol (1988) 25 (1)75-79. doi:10.1111/j.13652125.1988.tb03284.x

183. Luo H, Poland R, Lin K, Wan Y. Genetic polymorphism of cytochrome P450 2C19 in Mexican Americans: A cross-ethnic comparative study. Clin Pharmacol Ther (2006) 80 (1)33-40. doi:10.1016/j.clpt.2006.03.003

184. Sim SC, Nordin L, Andersson TM-L, Virding S, Olsson M, Pedersen NL, et al. Association between CYP2C19 polymorphism and depressive symptoms. Am J Med Genet Part B Neuropsychiatr Genet (2010) 153B1160-1166. doi:10.1002/ajmg.b.31081

185. Müller DJ, Kekin I, Kao ACC, Brandl EJ. Towards the implementation of CYP2D6 and CYP2C19 genotypes in clinical practice: update and report from a pharmacogenetic service clinic. Int Rev Psychiatry (2013) 25 (5)554-71. doi:10.3109/09540261.2013.838944

186. Goldman ML, Spaeth-Rublee B, Pincus HA. The case for severe mental illness as a disparities category. Psychiatr Serv (2018) 69 (6)726-728. doi:10.1176/appi.ps.201700138

187. Müller DJ, Brandl EJ, Degenhardt F, Domschke K, Grabe H, Gruber O, et al. Pharmakogenetik in der Psychiatrie: eine Standortbestimmung. Nervenarzt (2018) 89 (3)290-299. doi:10.1007/s00115-017-0479-8

188. Koopmans AB, Vinkers DJ, Gelan PJ, Hoek HW, van Harten PN. CYP2D6 and CYP2C19 genotyping in psychiatric patients on psychotropic medication in the former Dutch Antilles. Pharmacogenomics (2017) 18 (10)1003-1012. doi:10.2217/pgs-2017-0011

189. Borges S, Desta Z, Jin Y, Faouzi A, Robarge JD, Philips S, et al. Composite functional genetic and comedication CYP2D 6 activity score in predicting tamoxifen drug exposure among breast cancer patients. J Clin Pharmacol (2010) 50 (4)450-8. doi:10.1177/0091270009359182

190. Guidelines for ATC classification and DDD assignment 2014. WHO Collab Cent Drug Stat Methodol (2014) Oslo doi:10.1017/CBO9781107415324.004

191. Dingemans PM, Winter MF, Bleeker JAC, Rathod P. A cross-cultural study of the reliability and factorial dimensions of the Brief Psychiatric Rating Scale 
(BPRS). Psychopharmacology (Berl) (1983) 80190-191.

192. Gerlach J, Korsgaard S, Clemmesen P, Lund Laursen A, Magelund G, Noring $\mathrm{U}$, et al. The St. Hans Rating Scale for extrapyramidal syndromes: reliability and validitv. Acta Psychiatr Scand (1993) 87244-252.

193. Barnes TRE. A rating scale for drug-induced akathisia. Br J Psychiatry (1989) 154672-677.

194. Janno S, Holi MM, Tuisku K, Wahlbeck K. Actometry and Barnes Akathisia Rating Scale in neuroleptic-induced akathisia. Eur Neuropsychopharmacol (2005) 15 (1)39-41. doi:10.1016/j.euroneuro.2004.05.003

195. Mulhern B, Mukuria C, Barkham M, Knapp M, Byford S, Soeteman D, et al. Using generic preference-based measures in mental health: psychometric validity of the EQ-5D and SF-6D. Br J Psychiatry (2014) 205 (3)236-243. doi:10.1192/bjp.bp.112.122283

196. Üstün TB, Chatterji S, Kostanjsek N, Rehm J, Kennedy C, Epping-Jordan J, et al. Developing the World Health Organization Disability Assessment Schedule 2.0. Bull World Health Organ (2010) 88 (11)815-823. doi:10.2471/BLT.09.067231

197. Üstün T, Chatterji S, Villanueva M, Bendib L, Çelik C, Sadana R, et al. WHO Multi-country survey study on health and responsiveness 2000-2001 GPE discussion Paper No 37. (2001) November

198. de Haan L, Weisfelt M, Dingemans P, Linszen D, Wouters L. Psychometric properties of the Subjective Well-Being Under Neuroleptics scale and the Subjective Deficit Syndrome Scale. Psychopharmacology (Berl) (2002) 162 (1)24-28. doi:10.1007/s00213-002-1054-x

199. Risselada AJ. Switchen van en naar depotantipsychotica. Psyfar (2012) december (4)18-23.

200. Moncrieff J, Leo J. A systematic review of the effects of antipsychotic drugs on brain volume. Psychol Med (2010) 40 (09)1409-1422. doi:10.1017/S0033291709992297

201. Owens DG, Johnstone EC, Crow TJ, Frith CD, Jagoe JR, Kreel L. Lateral ventricular size in schizophrenia: relationship to the disease process and its clinical manifestations. Psychol Med (1985) 15 (1)27-41. 
203. de Andrés F, Terán S, Hernández F, Terán E, LLerena A. To genotype or phenotype for personalized medicine? CYP450 drug metabolizing enzyme genotype-phenotype concordance and discordance in the Ecuadorian population. Omi A J Integr Biol (2016) 20 (12)699-710. doi:10.1089/omi.2016.0148

204. van Harten PN, Hoek HW, Matroos GE, Koeter M, Kahn RS. Intermittent Neuroleptic Treatment and Risk for Tardive Dyskinesia: Curaçao Extrapyramidal Syndromes Study III. Am J Psychiatry (1998) 155 (4)565-567. doi:10.1176/ajp.155.4.565

205. Thomas EC, Despeaux KE, Drapalski AL, Bennett M. Person-oriented recovery of individuals with serious mental illnesses: $A$ review and meta-analysis of longitudinal findings. Psychiatr Serv (2018) 69 (3)259-267. doi:10.1176/appi.ps.201700058

206. Drake RE, Whitley R. Recovery and severe mental illness: Description and analysis. Can J Psychiatry (2014) 59 (5)236-242. doi:10.1177/070674371405900502

207. Whitley R. Introducing recovery. Can J Psychiatry (2014) 59 (5)233-235. doi:10.1177/070674371405900501

208. Jääskeläinen $\mathrm{E}$, Juola $\mathrm{P}$, Hirvonen $\mathrm{N}$, McGrath JJ, Saha $\mathrm{S}$, Isohanni $\mathrm{M}$, et al. $A$ systematic review and meta-analysis of recovery in schizophrenia. Schizophr Bull (2013) 39 (6)1296-1306. doi:10.1093/schbul/sbs130

209. Liberman RP, Kopelowicz A, Ventura J, Gutkind D. Operational criteria and factors related to recovery from schizophrenia. Int Rev Psychiatry (2002) 14 (4)256-272. doi:10.1080/0954026021000016905

210. Marx BP, Wolf EJ, Cornette MM, Schnurr PP, Rosen MI, Friedman MJ, et al. Using the WHODAS 2.0 to assess functioning among veterans seeking compensation for Posttraumatic Stress Disorder. Psychiatr Serv (2015) 66 (12)1312-1317. doi:10.1176/appi.ps.201400400

211. Gold LH. DSM-5 and the assessment of functioning: the World Health Organization Disability Assessment Schedule 2.0 (WHODAS 2.0). J Am Acad Psychiatry Law (2014) 42 (2)173-81. Available at: http://www.ncbi.nlm.nih.gov/pubmed/24986344

212. Hofer A, Baumgartner S, Edlinger $M$, Hummer $M$, Kemmler $G$, Rettenbacher MA, et al. Patient outcomes in schizophrenia I: Correlates with sociodemographic variables, psychopathology, and side effects. Eur Psychiatry (2005) 20 (5-6)386-394. doi:10.1016/j.eurpsy.2005.02.005 
213. Asher L, Hanlon C, Birhane R, Habtamu A, Eaton J, Weiss HA, et al.

Community-based rehabilitation intervention for people with schizophrenia in Ethiopia (RISE): a 12 month mixed methods pilot study. BMC Psychiatry (2018) 18 (1)250. doi:10.1186/s12888-018-1818-4

214. McInerney SJ, Finnerty S, Walsh E, Spelman L, Edgar NE, Hallahan B, et al. Quality of life and social functioning of former long-stay psychiatric patients transferred into the community: a 10 year follow up study. Soc Psychiatry Psychiatr Epidemiol (2018) 53 (8)795-801. doi:10.1007/s00127-018-1520-3

215. Chen R, Liou T-H, Miao N-F, Chang K-H, Yen C-F, Liao H-F, et al. Using World Health Organization Disability Assessment Schedule 2.0 in people with schizophrenia: a 4-year follow-up. Eur Arch Psychiatry Clin Neurosci (2020) 270 (3)301-310. doi:10.1007/s00406-019-01000-5

216. Habtamu K, Alem A, Medhin G, Fekadu A, Hanlon C. Functional impairment among people with severe and enduring mental disorder in rural Ethiopia: $a$ cross-sectional study. Soc Psychiatry Psychiatr Epidemiol (2018) 53 (8)803814. doi:10.1007/s00127-018-1546-6

217. Downing NR, Kim J-I, Williams JK, Long JD, Mills JA, Paulsen JS. WHODAS 2.0 in prodromal Huntington disease: measures of functioning in neuropsychiatric disease. Eur J Hum Genet (2014) 22 (8)958-963. doi:10.1038/ejhg.2013.275

218. World Health Organization (2010) WHO Disability Assessment Schedule (WHODAS 2.0), 36-item proxy version (official Dutch translation by D. van Hoeken \& H.W. Hoek, Parnassia Psychiatric Institute, The Hague, the Netherlands). (2012) Available at: https://www.whofic.nl/en

219. Siu CO, Harvey PD, Agid O, Waye M, Brambilla C, Choi W-K, et al. Insight and subjective measures of quality of life in chronic schizophrenia. Schizophr Res Cogn (2015) 2 (3)127-132. doi:10.1016/j.scog.2015.05.002

220. Harvey PD, Twamley EW, Pinkham AE, Depp CA, Patterson TL. Depression in Schizophrenia: Associations With Cognition, Functional Capacity, Everyday Functioning, and Self-Assessment. Schizophr Bull (2016) 43 (3)sbw103. doi:10.1093/schbul/sbw103

221. Ermel J, Carter CS, Gold JM, MacDonald AW, Daniel Ragland J, Silverstein $\mathrm{SM}$, et al. Self versus informant reports on the specific levels of functioning scale: Relationships to depression and cognition in schizophrenia and schizoaffective disorder. Schizophr Res Cogn (2017) 9 (May)1-7. doi:10.1016/j.scog.2017.04.001

222. Sabbag S, Twamley EW, Vella L, Heaton RK, Patterson TL, Harvey PD. 
Predictors of the accuracy of self assessment of everyday functioning in people with schizophrenia. Schizophr Res (2012) 137 (1-3)190-195.

doi:10.1016/j.schres.2012.02.002

223. Durand D, Strassnig M, Sabbag S, Gould F, Twamley EW, Patterson TL, et al. Factors influencing self-assessment of cognition and functioning in schizophrenia: Implications for treatment studies. Eur Neuropsychopharmacol (2015) 25 (2)185-191. doi:10.1016/j.euroneuro.2014.07.008

224. Van Hoeken D, Heerkens YF, De Kleijn-de Vrankrijker MW, Hoek HW. In: Üstün TB, Chatterji S, Bickenbach JE, Trotter II RT, Room R, Rehm J, Saxena S, editors. Disability and Culture: Universalism and Diversity. (2001).

225. Üstün TB, Kostanjsek N, Chatterji S, Rehm J. Measuring health and disability: Manual for WHO Disability Assessment Schedule WHODAS 2.0 (2010).

226. Federici S, Bracalenti M, Meloni F, Luciano J V. World Health Organization disability assessment schedule 2.0: An international systematic review. Disabil Rehabil (2017) 39 (23)2347-2380. doi:10.1080/09638288.2016.1223177

227. Dingemans $\mathrm{P}$, Linszen $\mathrm{D}$, Lenior $\mathrm{M}$, Smeets R. Component structure of the expanded Brief Psychiatric Rating Scale (BPRS-E). Psychopharmacology (Berl) (1995) 122 (July)263-267.

228. Shafer A. Meta-analysis of the Brief Psychiatric Rating Scale factor structure. Psychol Assess (2005) 17 (3)324-335. doi:10.1037/1040-3590.17.3.324

229. Barton GR, Hodgekins J, Mugford M, Jones PB, Croudace T, Fowler D. Measuring the benefits of treatment for psychosis: validity and responsiveness of the EQ-5D. Br J Psychiatry (2009) 195 (2)170-177. doi:10.1192/bjp.bp.108.057380

230. Green CA, Perrin NA, Leo MC, Janoff SL, Yarborough BJH, Paulson RI. Recovery from serious mental illness: Trajectories, characteristics, and the role of mental health care. Psychiatr Serv (2013) 64 (12)1203-1210. doi:10.1176/appi.ps.201200545

231. Degnan A, Berry K, Sweet D, Abel K, Crossley N, Edge D. Social networks and symptomatic and functional outcomes in schizophrenia: a systematic review and meta-analysis. Soc Psychiatry Psychiatr Epidemiol (2018) 53 (9)873-888. doi:10.1007/s00127-018-1552-8

232. Apiquian R, Elena Ulloa R, Herrera-Estrella M, Moreno-Gómez A, Erosa S, Contreras V, et al. Validity of the Spanish version of the Personal and Social Performance scale in schizophrenia. Schizophr Res (2009) 112 (1-3)181-186. doi:10.1016/j.schres.2009.03.028 
233. Lord S, Godfrey A, Galna B, Mhiripiri D, Burn D, Rochester L. Ambulatory activity in incident Parkinson's: more than meets the eye? J Neurol (2013) 260 (12)2964-72. doi:10.1007/s00415-013-7037-5

234. Cavanaugh JT, Ellis TD, Earhart GM, Ford MP, Foreman KB, Dibble LE. Toward understanding ambulatory activity decline in Parkinson disease. Phys Ther (2015) 95 (8)1142-1150. doi:10.2522/ptj.20140498

235. Thordardottir B, Nilsson MH, Iwarsson S, Haak M. "You plan, but you never know" - participation among people with different levels of severity of Parkinson's disease. Disabil Rehabil (2014) 36 (26)2216-2224. doi:10.3109/09638288.2014.898807

236. Ahn HJ, Yoo W-K, Park J, Ma H-I, Kim YJ. Cognitive dysfunction in druginduced parkinsonism caused by prokinetics and antiemetics. J Korean Med Sci (2015) 30 (9)1328. doi:10.3346/jkms.2015.30.9.1328

237. Kim J-H, Kim S-Y, Byun H-J. Subjective cognitive dysfunction associated with drug-induced parkinsonism in schizophrenia. Parkinsonism Relat Disord (2008) 14 (3)239-242. doi:10.1016/j.parkreldis.2007.07.009

238. Kim Y Do, Kim JS, Chung SW, Song IU, Yang DW, Hong YJ, et al. Cognitive dysfunction in drug induced parkinsonism (DIP). Arch Gerontol Geriatr (2011) 53 (2)222-226. doi:10.1016/j.archger.2010.11.025

239. Sabbag S, Twamley EM, Vella L, Heaton RK, Patterson TL, Harvey PD. Assessing everyday functioning in schizophrenia: Not all informants seem equally informative. Schizophr Res (2011) 131 (1-3)250-255. doi:10.1016/j.schres.2011.05.003

240. Leucht S, Cipriani A, Spineli L, Mavridis D, Örey D, Richter F, et al. Comparative efficacy and tolerability of 15 antipsychotic drugs in schizophrenia: a multiple-treatments meta-analysis. Lancet (2013) 382 (9896)951-962. doi:10.1016/S0140-6736(13)60733-3

241. Cipriani A, Furukawa TA, Salanti G, Chaimani A, Atkinson LZ, Ogawa Y, et al. Comparative efficacy and acceptability of 21 antidepressant drugs for the acute treatment of adults with major depressive disorder: a systematic review and network meta-analysis. Lancet (2018) 391 (10128)1357-1366. doi:10.1016/S0140-6736(17)32802-7

242. Zhang L, Brown SJ, Shan Y, Lee AM, Allen JD, Eum S, et al. CYP2D6 Genetic Polymorphisms and Risperidone Pharmacokinetics: A Systematic Review and Meta-analysis. Pharmacother J Hum Pharmacol Drug Ther (2020) 40 (7)632647. doi:10.1002/phar.2434 
243. Tveito M, Molden E, Høiseth G, Correll CU, Smith RL. Impact of age and CYP2D6 genetics on exposure of aripiprazole and dehydroaripiprazole in patients using long-acting injectable versus oral formulation: relevance of poor and intermediate metabolizer status. Eur J Clin Pharmacol (2020) 76 (1)41-49. doi:10.1007/s00228-019-02768-0

244. Calafato MS, Austin-Zimmerman I, Thygesen JH, Sairam M, Metastasio A, Marston $\mathrm{L}$, et al. The effect of CYP2D6 variation on antipsychotic-induced hyperprolactinaemia: a systematic review and meta-analysis.

Pharmacogenomics J (2020) doi:10.1038/s41397-019-0142-9

245. Jukic MM, Smith RL, Haslemo T, Molden E, Ingelman-Sundberg M. Effect of CYP2D6 genotype on exposure and efficacy of risperidone and aripiprazole: $a$ retrospective, cohort study. The Lancet Psychiatry (2019) 6 (5)418-426. doi:10.1016/S2215-0366(19)30088-4

246. Hicks JK, Bishop JR, Sangkuhl K, Muller DJ, Ji Y, Leckband SG, et al. Clinical Pharmacogenetics Implementation Consortium (CPIC) guideline for CYP2D6 and CYP2C19 genotypes and dosing of selective serotonin reuptake inhibitors. Clin Pharmacol Ther (2015) 98 (2)127-134. doi:10.1002/cpt.147

247. Hicks JK, Bishop JR, Gammal RS, Sangkuhl K, Bousman CA, Leeder JS, et al. $A$ Call for Clear and Consistent Communications Regarding the Role of Pharmacogenetics in Antidepressant Pharmacotherapy. Clin Pharmacol Ther (2020) 107 (1)50-52. doi:10.1002/cpt.1661

248. Cicali EJ, Weitzel KW, Elsey AR, Orlando FA, Vinson M, Mosley S, et al. Challenges and lessons learned from clinical pharmacogenetic implementation of multiple gene-drug pairs across ambulatory care settings. Genet Med (2019) 21 (10)2264-2274. doi:10.1038/s41436-019-0500-7

249. Arwood MJ, Dietrich EA, Duong BQ, Smith DM, Cook K, Elchynski A, et al. Design and Early Implementation Successes and Challenges of a Pharmacogenetics Consult Clinic. J Clin Med (2020) 9 (7)2274. doi:10.3390/jcm9072274

250. Ma L, Shcherbina A, Chetty S. Variations and expression features of CYP2D6 contribute to schizophrenia risk. Mol Psychiatry (2020) doi:10.1038/s41380020-0675-y

251. Jaracz K, Górna K, Kiejda J, Grabowska-Fudala B, Jaracz J, Suwalska A, et al. Psychosocial functioning in relation to symptomatic remission: A longitudinal study of first episode schizophrenia. Eur Psychiatry (2015) 30 (8)907-913. doi:10.1016/j.eurpsy.2015.08.001 
252. Koopmans AB, van Hoeken D, Clarke DE, Vinkers DJ, van Harten PN, Hoek HW. Proxy WHO Disability Assessment Schedule 2.0 Is Clinically Useful for Assessing Psychosocial Functioning in Severe Mental Illness. Front Psychiatry (2020) 11 (April)1-8. doi:10.3389/fpsyt.2020.00303

253. Solomon H V., Cates KW, Li KJ. Does obtaining CYP2D6 and CYP2C19 pharmacogenetic testing predict antidepressant response or adverse drug reactions? Psychiatry Res (2019) 271 (December 2018)604-613. doi:10.1016/j.psychres.2018.12.053

254. Kurylev AA, Brodyansky VM, Andreev B V, Kibitov AO, Limankin O V, Mosolov SN. The combined effect of CYP2D6 and DRD2 Taq $1 A$ polymorphisms on the antipsychotics daily doses and hospital stay duration in schizophrenia inpatients (observational naturalistic study). Psychiatr Danub (2018) 30 (2)157-163. doi:10.24869/psyd.2018.157

255. Alenius $M$, Wadelius M, Dahl M-L, Hartvig P, Lindström L, HammarlundUdenaes M. Gene polymorphism influencing treatment response in psychotic patients in a naturalistic setting. J Psychiatr Res (2008) 42 (11)884-893. doi:10.1016/j.jpsychires.2007.10.007

256. Leucht S, Crippa A, Ph D, Sia S, Patel MX, Orsini N, et al. Dose-Response Meta-Analysis of Antipsychotic Drugs for Acute Schizophrenia. (2018)1-12. doi:10.1176/appi.ajp.2019.19010034

257. Veselinović T, Scharpenberg M, Heinze M, Cordes J, Mühlbauer B, Juckel G, et al. Dopamine D2 Receptor Occupancy Estimated From Plasma Concentrations of Four Different Antipsychotics and the Subjective Experience of Physical and Mental Well-Being in Schizophrenia. J Clin Psychopharmacol (2019) 39 (6)550-560. doi:10.1097/JCP.0000000000001131

258. Jaanson P, Marandi T, Kiivet R-A, Vasar V, Vään S, Svensson J-O, et al. Maintenance therapy with zuclopenthixol decanoate: associations between plasma concentrations, neurological side effects and CYP2D6 genotype. Psychopharmacology (Berl) (2002) 162 (1)67-73. doi:10.1007/s00213-0021059-5

259. Andreassen OA, MacEwan T, Gulbrandsen AK, McCreadie RG, Steen VM. Non-functional CYP2D6 alleles and risk for neuroleptic-induced movement disorders in schizophrenic patients. Psychopharmacology (Berl) (1997) 131 (2)174-179. doi:10.1007/s002130050281

260. De Leon J, Barnhill J, Rogers T, Boyle J, Chou WH, Wedlund PJ. Pilot study of the cytochrome P450-2D6 genotype in a psychiatric state hospital. Am J Psychiatry (1998) 155 (9)1278-1280. 
261. Li M. Antipsychotic-induced sensitization and tolerance: Behavioral characteristics, developmental impacts, and neurobiological mechanisms. J Psychopharmacol (2016) 30 (8)749-770. doi:10.1177/0269881116654697

262. Yin J, Barr A, Ramos-Miguel A, Procyshyn R. Antipsychotic Induced Dopamine Supersensitivity Psychosis: A Comprehensive Review. Curr Neuropharmacol (2016) 15 (1)174-183. doi:10.2174/1570159X14666160606093602

263. Seeman P. All Roads to Schizophrenia Lead to Dopamine Supersensitivity and Elevated Dopamine D2High Receptors. CNS Neurosci Ther (2011) 17 (2)118132. doi:10.1111/j.1755-5949.2010.00162.x

264. Kanahara N, Yoshimura K, Nakamura M, Oda Y, Watanabe M, lyo M. Metabolism of risperidone by CYP2D 6 and the presence of drug-induced dopamine supersensitivity psychosis in patients with schizophrenia. Int Clin Psychopharmacol (2019) 34 (3)124-130. doi:10.1097/YIC.0000000000000257

265. Liu C-C, Takeuchi H. Achieving the Lowest Effective Antipsychotic Dose for Patients with Remitted Psychosis: A Proposed Guided Dose-Reduction Algorithm. CNS Drugs (2020) 34 (2)117-126. doi:10.1007/s40263-01900682-8

266. Kropp S, Lichtinghagen R, Winterstein K, Schlimme J, Schneider U. Cytochrome P-450 2D6 and 2C19 polymorphisms and length of hospitalization in psychiatry. Clin Lab (2006) 52237-240.

267. Swen JJ, Nijenhuis M, de Boer A, Grandia L, Maitland-van der Zee AH, Mulder H, et al. Supplement to: Pharmacogenetics: From Bench to Byte-An Update of Guidelines. Clin Pharmacol Ther (2011) 89 (5)662-673. doi:10.1038/clpt.2011.34

268. Ellingrod L, Skaar TC, Müller DJ, Gaedigk A, Stingl JC. Supplement to: Clinical Pharmacogenetics Implementation Consortium Guideline for. (2017) 49 (0)120.

269. Hicks JK, Bishop JR, Sangkuhl K, Müller DJ, Ji Y, Leckband SG, et al. Supplement to: Clinical Pharmacogenetics Implementation Consortium (CPIC) Guideline for CYP2D6 and CYP2C19 Genotypes and Dosing of SSRIs. 98: 2 (2015).

270. Wang L, Yu L, Zhang A-P, Fang C, Du J, Gu N-F, et al. Serum prolactin levels, plasma risperidone levels, polymorphism of cytochrome P450 2D6 and clinical response in patients with schizophrenia. J Psychopharmacol (2007) 21 (8)837-842. doi:10.1177/0269881107077357

271. Paulzen M, Haen E, Stegmann B, Unterecker S, Hiemke C, Gründer G, et al. 
Clinical response in a risperidone-medicated naturalistic sample: patients' characteristics and dose-dependent pharmacokinetic patterns. Eur Arch Psychiatry Clin Neurosci (2017) 267 (4)325-333. doi:10.1007/s00406-0160736-z

272. Llerena A, Berecz R, Dorado P, de la Rubia A. QTc Interval, CYP2D6 and CYP2C9 Genotypes and Risperidone Plasma Concentrations. J

Psychopharmacol (2004) 18 (2)189-193. doi:10.1177/0269881104042618

273. Koopmans AB, Braakman MH, Vinkers DJ, Hoek HW, van Harten PN. Metaanalysis of probability estimates of worldwide variation of CYP2D6 and CYP2C19. Transl Psychiatry (2021) doi:10.1038/s41398-020-01129-1

274. Rehm J, Shield KD. Global Burden of Disease and the Impact of Mental and Addictive Disorders. Curr Psychiatry Rep (2019) 21 (2)10. doi:10.1007/s11920-019-0997-0

275. Mulder $\mathrm{H}$, Heerdink ER, Lersel EE van, Wilmink FW, Egberts ACG. Prevalence of Patients Using Drugs Metabolized by Cytochrome P450 2D6 in Different Populations: a Cross-Sectional Study. Ann Pharmacother (2007) 41 (3)408413. doi:10.1345/aph.1H482

276. Bousman CA, Jaksa P, Pantelis C. Systematic evaluation of commercial pharmacogenetic testing in psychiatry. Pharmacogenet Genomics (2017) 27 (11)387-393. doi:10.1097/FPC.0000000000000303

277. Vinkers $\mathrm{CH}$. Te vroeg voor farmacogenetica in de psychiatrische praktijk. Tijdschr Psychiatr (2019) 61 (5)298-300.

278. van Westrhenen $\mathrm{R}$, Bet PM, van Weelden $\mathrm{M}$, van Schaik RHN. Te vroeg voor farmacogenetica in de psychiatrische praktijk? Implementatie is volop gaande. Tijdschr Psychiatr (2019) 61 (10)678-680. 



\section{SUPPLEMENTAL MATERIAL}

This supplemental material belongs to Chapter 2. It is available as electronic content published along with the open access article.

Supplemental Table 1. References of Table 2 - Chapter 2

Africa

African American

Americas

Central/ South East Asia

East Asia

Europe

Middle East

Oceania
$(1-29)$

$(20,30-40)$

$(2,3,20,22,32,34,41-85)$

$(1-3,20,22,31,34,36,86-119)$

$(3,10,57,87,90,96,120-125,20,126-135,22,136-$ $145,24,146-155,31,156-165,32,166-175,34,176-$ $185,36,186,48)$

$(1,2,24,30-32,34,36-39,62,3,101,125,131,187-193,4,194-$ 203,5,204-213,10,214-223,14,224-233,15,234243,20,244-253,22,254-261)

$(3,31,36,262-297)$

$(3,32,128,298-300)$ 
Supplemental Table 2. References of Table 3 - Chapter 2

\section{Africa}

African

African (north and East)

Biaka, Pygmies (Subsaharan Africa)

Colored (South African)

Esan (Nigerian)

Gambian

Luhya in Webuye (Kenian)

Mandenka (Subsaharan Africa)

Mende (Sierra Leonean)

Mozabite (Algerian)

North African

South African

West African

Xhosa (South African)

Yoruba (Nigerian) (Ibadan)

Yoruba (Subsaharan Africa)

\section{African American}

\section{Americas}

Admixed Latin Americans

$(22,81)$

African Caribbean (Barbados)

African Caribbean from Barbados (Costa Rica)

Afro-Latin Americans

American Indian

Brazilian (North East)

Brazilian (North)

Brazilian (South East)

Brazilian (South)

Brazilian from African descent

Brazilian from Caucasian descent

Central Native Americans

Colombian

Coras (Mexican)

Cuban from Caucasian descent 
Dutch Caribbean

Ecuadorian

Huicholes (Mexican)

Iberians

Indo-Trinidad

Jewish (Ashkenazi)

Karitiana (South American)

Lacandones (Mexican)

Maya (Mexican)

Maya (South American)

Mestizo (Cuban)

Mestizo (Mexican)

Mestizo (Nicarguan)

Mexican

North Native Americans

Peruvian

Pima (South American)

Puerto Rican

South American

South Native Americans

Surui (South American)

Tarahumares (Mexican)

Tepehuanos (Mexican)

White Latin Americans

\section{Central/ South East Asia}

Balochi (Central/South Asia)

Bengali

Brahui (Central/South Asia)

Burusho (Central/South Asia)

Gujarati (Indian)

Hazara (Central/South Asia)

Kalash (Central/South Asia)

Makrani (Central/South Asia)

Pathan (Central/South Asia)

Punjabi (Indian)

Sindhi (Central/South Asia)
(69)

(83)

(3)

$(44,67,77)$

$(58,303)$

$(20,53,68,83)$

(81)

(3)

(20)

(2)

(3) 
South Asian

South East Asia

(2)

Tamil (Sri Lankan)

Telugu (Indian)

Uyghurs (Central/South Asia)

Viet Kinh (Vietnamese)

Western India

\section{East Asia}

Chinese

$(96,131,132)$

Dai (Chinese)

East Asian

Han (Chinese)

$(20,87,129,142)$

Han (East Asia)

(3)

Japanese

$(3,20,131,136,161)$

Shanghai (Chinese)

Shantou (Chinese)

Shenyang (Chinese)

South Korean

$(127,131,138,184)$

Tibetan Chinese

Xi'an (Chinese)

Yakut (East Asia)

(3)

\section{Europe}

Basque (French)

(3)

British

Caucasian (Danish)

(201)

Caucasian (European)

$(22,260)$

Caucasian (Hungarian)

Caucasian (USA)

$(20,230)$

Estonian

Finnish

Finnish (East)

Finnish (West)

French

German

Iberian (Spanish)

(20) 


\section{Middle East}

Arabian Bedouins (Israel)

Bedouin (Middle Eastern)

Druze (Middle Eastern)

Jewish (Israel)

Palestinian (Westbank)

\section{Oceania}

Aboriginal (North West Australia)

non-Austronesian Melanesian 
Supplemental Table 3. References of Table 4 - Chapter 2

Africa

African

Cape Mixed Ancestry (South African)

Tzotziles (Ugandese)

Xhosa (South African)

African American

(30)(32)

\section{Americas}

Admixed Latin Americans

African Caribbeans from Barbados (Costa Rica)

Brazilian

Bribri (Costa Rican)

Costa Rican

Dutch Caribbean

Ecuadorian

Guarani (Brazil)

Guaymi (Costa Rican)

Mestizo (Costa Rican)

Mestizo (Ecuadorian)

Mestizo (Mexican)

Mexican

$(68,80)$

\section{Central/ South East Asia}

Buruhi (Pakistani)

Burushu (Pakistani)

Hazara (Pakistani)

Indian (West)

Kalash (Pakistani)

Koya (Indian)

Naik (Indian)

Pakistani

Parsi (Pakistani)

Pathan (Pakistani)

Punjabi (Pakistani) 


\section{Supplemental material}

Saraiki (Pakistani)

Sindhi (Pakistani)

South Asian

Tamil (Indian) (South)

\section{East Asia}

Bai (Chinese)

Chinese

$(31,57,93,131)$

East Asian

$(22,24,32,34)$

Hakka (Chinese)

(182)

Han (Chinese)

$(120,123,124,128,129,145,177)$

Han (Chinese) (North)

(154)

Han (Chinese) (South)

Han (Taiwanese)

Hui (Chinese)

$(123,124)$

Japanese

(24)

Japanese

$(31,48,131,133,135,140,144,146,165,169,170)$

Kazakh (Chinese)

(128)

Li (Chinese)

$(162,176)$

Mongolian

$(123,124,158)$

Shanghai (Chinese)

(130)

Shantou (Chinese)

(130)

Shenyang (Chinese)

South Korean

$(24,90,122,125,126,131,147,159)$

Tibetan Chinese

Tohoku (Japanese)

(165)

Uyghurs (Chinese)

$(124,128,179)$

Xi'an (Chinese)

(130)

\section{Europe}

Avars (Russian)

(245)

Caucasian (European)

$(22,131,260)$

Caucasian (USA)

$(30,32)$

Danish

Dargins (Russian)

Estonian

Faroese 
Finnish (North)

Greek

Hispanic (USA)

$(30,32)$

Jewish

(30)

Jewish (Ashkenazi)

$(190,260)$

Jewish (Sephardi)

Laks (Russian)

Macedonian

Nanai (Russian)

Norwegian

Scandinavian

Spanish (North)

Swedish

\section{Middle East}

Caspian (Iranian)

(304)

Fars (Iranian)

Iranian

$(286,289)$

Kurd (Iranian)

Lure (Iranian)

(304)

Saoudi Arabian

$(271,292)$

Turk (Iranian)

(304)

Turkish

\section{Oceania}

Pacific Islander 
This supplemental material belongs to Chapter 2. It is available as electronic content published along with the open access article.

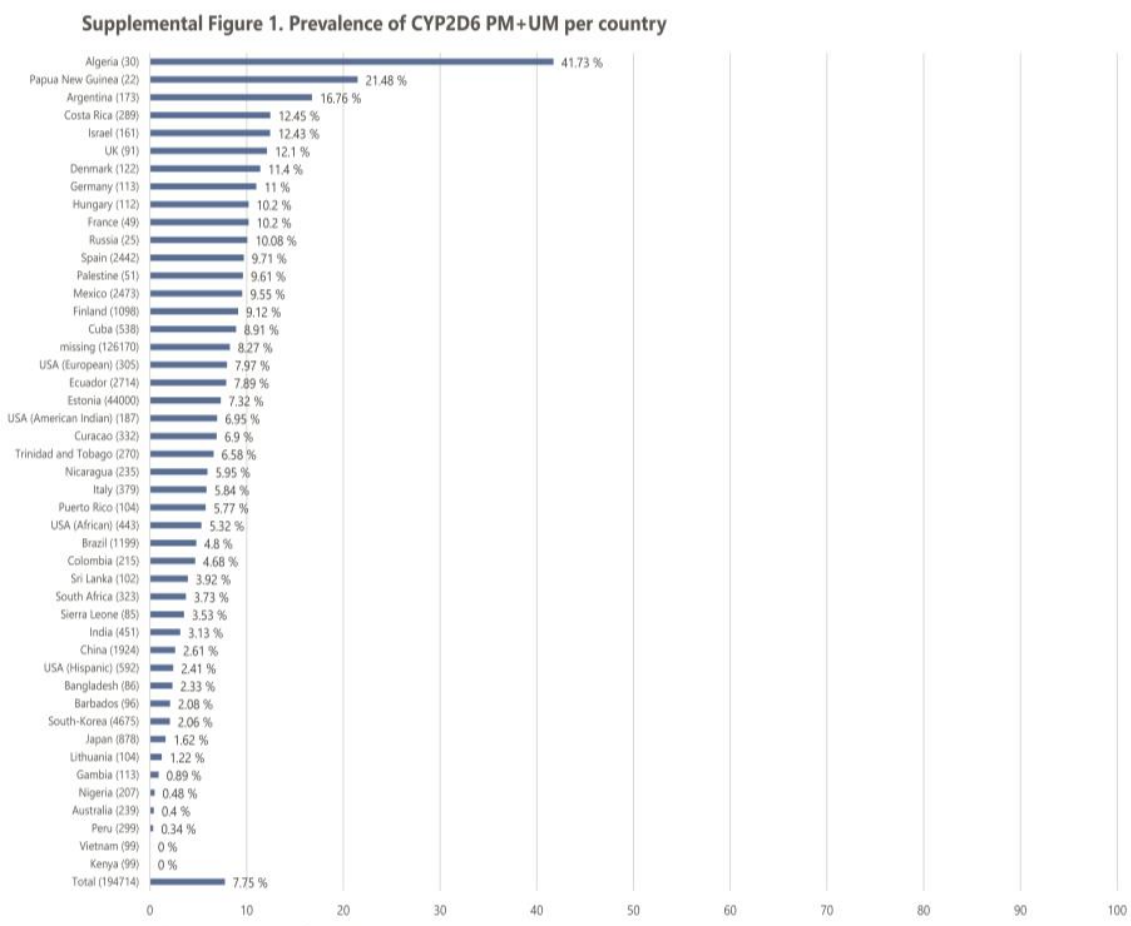

Country (genotyped subjects); Prevalence of PM+UM in \%

Supplemental Figure 2. Prevalence of CYP2C19 PM+UM per country
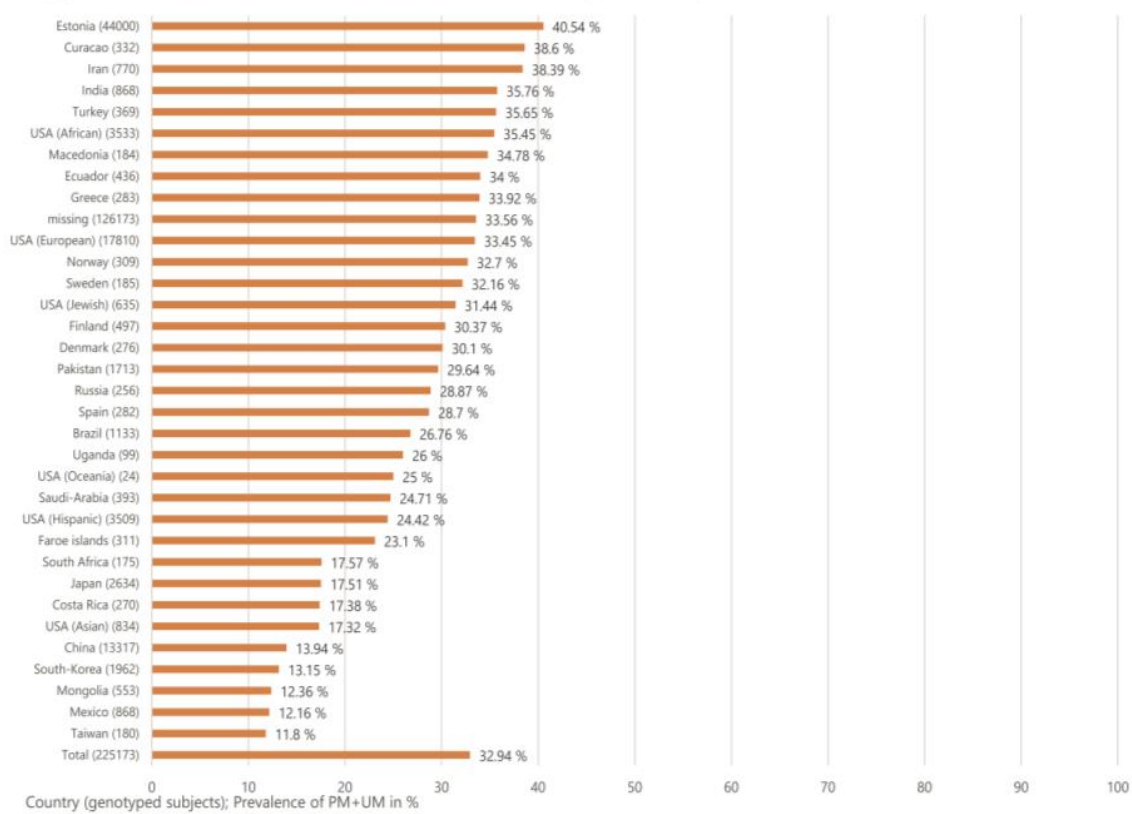



\section{Supplemental references}

1. Dodgen TM, Hochfeld WE, Fickl H, Asfaha SM, Durandt $C$, Rheeder $\mathrm{P}$, et al. Introduction of the AmpliChip CYP450 Test to a South African cohort: a platform comparative prospective cohort study. BMC Med Genet (2013) 14 (1)20. doi:10.1186/1471-2350-14-20

2. Riccardi LN, Lanzellotto R, Luiselli D, Ceccardi S, Falconi M, Bini C, et al. CYP2D6 Genotyping in Natives and Immigrants from the Emilia-Romagna Region (Italy). Genet Test Mol Biomarkers (2011) 15 (11)801-806. doi:10.1089/gtmb.2010.0221

3. Sistonen J, Sajantila A, Lao O, Corander J, Barbujani G, Fuselli S. CYP2D6 worldwide genetic variation shows high frequency of altered activity variants and no continental structure. Pharmacogenet Genomics (2007) 17 (2)93-101.

4. Allabi AC, Gala J-L, Desager J-P, Heusterspreute M, Horsmans Y. Genetic polymorphisms of CYP2C9 and CYP2C19 in the Beninese and Belgian populations. Br J Clin Pharmacol (2003) 56 (6)653-657. doi:10.1046/j.13652125.2003.01937.x

5. Aklillu E, Herrlin K, Gustafsson LL, Bertilsson L, Ingelman-Sundberg M. Evidence for environmental influence on CYP2D6-catalysed debrisoquine hydroxylation as demonstrated by phenotyping and genotyping of Ethiopians living in Ethiopia or in Sweden. Pharmacogenetics (2002) 12 (5)375-383. doi:10.1097/00008571-200207000-00005

6. Hamdy SI, Hiratsuka M, Narahara K, El-Enany M, Moursi N, Ahmed MS-E, et al. Allele and genotype frequencies of polymorphic cytochromes $P 450$ (CYP2C9, CYP2C19, CYP2E1) and dihydropyrimidine dehydrogenase (DPYD) in the Egyptian population. Br J Clin Pharmacol (2002) 53 (6)596-603. doi:10.1046/j.1365-2125.2002.01604.x

7. Bathum L, Skjelbo E, Mutabingwa TK, Madsen H, Hørder M, Brøsen K. Phenotypes and genotypes for CYP2D6 and CYP2C19 in a black Tanzanian population. Br J Clin Pharmacol (1999) 48 (3)395-401. doi:10.1046/j.13652125.1999.00019.x

8. Griese E-U, Asante-Poku S, Ofori-Adjei D, Mikus G, Eichelbaum M. Analysis of the CYP2d6 gene mutations and their consequences for enzyme function in a West-African population. Pharmacogenetics (1999) 9715-723. 
9. Wennerholm A, Johansson I, Massele AY, Jande M, Alm C, Aden-Abdi Y, et al. Decreased capacity for debrisoquine metabolism among black Tanzanians. Pharmacogenetics (1999) 9 (6)707-714. doi:10.1097/00008571-19991200000005

10. Droll K, Bruce-Mensah K, Victoria Otton S, Gaedigk A, Sellers EM, Tyndale RF. Comparision of three CYP2D6 probe substrates and genotype in Ghanaians, Chinese and Caucasians. Pharmacogenetics (1998) 8325-333.

11. Persson I, Aklillu E, Rodrigues F, Bertilsson L, Ingelman-Sundberg M. Smephenytoin hydroxylation phenotype and CYP2C19 genotype among Ethiopians. Pharmacogenetics (1996) 6521-526.

12. Masimirembwa C, Bertilsson L, Johansson I, Hasler JA, Ingelman-Sundberg M. Phenotyping and genotyping of S-mephenytoin hydroxylase (cytochrome P450 2C19) in a Shona population of Zimbabwe. Clin Pharmacol Ther (1995) 57 (6)656-661. doi:10.1016/0009-9236(95)90228-7

13. Babalola CP, Adejumo O, Bs DU, Ms ZX, Fimls AO, Mbbs TK, et al. Cytochrome P450 CYP2C19 genotypes in Nigerian sickle-cell disease patients and normal controls. Pharmacogenetics (2010) 35471-477. doi:10.1111/j.1365-2710.2009.01122.x

14. Evans WE, Relling M V, Rahman A, McLeod HL, Scott EP, Lin JS. Genetic basis for a lower prevalence of deficient CYP2D6 oxidative drug metabolism phenotypes in black Americans. J Clin Invest (1993) 91 (5)2150-2154. doi:10.1172/JCl116441

15. Riccardi LN, Bini C, Ceccardi S, Trane R, Luiselli D, Pelotti S. CYP2D6 polymorphism studies: How forensic genetics helps clinical medicine. Forensic Sci Int Genet Suppl Ser (2009) 2 (1)485-486. doi:10.1016/j.fsigss.2009.08.028

16. Wennerholm A, Johansson I, Hidestrand M, Bertilsson L, Gustafsson LL, Ingelman-Sundberg M. Characterization of the CYP2D6*29 allele commonly present in a black Tanzanian population causing reduced catalytic activity. Pharmacogenetics (2001) 11 (5)417-27. Available at: http://www.ncbi.nlm.nih.gov/pubmed/11470994

17. Herrlin K, Massele AY, Jande M, Alm C, Tybring G, Abdi YA, et al. Bantu Tanzanians have a decreased capacity to metabolize omeprazole and mephenytoin in relation to their CYP2C19 genotype*. Clin Pharmacol Ther (1998) 64 (4)391-401. doi:10.1016/S0009-9236(98)90070-4

18. Masimirembwa C, Hasler J, Bertilssons L, Johansson I, Ekberg O, IngelmanSundberg M. Phenotype and genotype analysis of debrisoquine hydroxylase 
(CYP2D6) in a black Zimbabwean population. Eur J Clin Pharmacol (1996) 51 (2)117-122. doi:10.1007/s002280050170

19. Afilal D, Basselam MA, Brakez Z, Chouham S, Brehm A, Izaabel EH. Genetic Polymorphism of Drug-Metabolizing Enzymes CYP2C9 and CYP2C19 in Moroccan Population. Genet Test Mol Biomarkers (2017) 21 (5)298-304. doi:10.1089/gtmb.2016.0304

20. Wendt FR, Pathak G, Sajantila A, Chakraborty R, Budowle B. Global genetic variation of select opiate metabolism genes in self-reported healthy individuals. Pharmacogenomics J (2018) 18 (2)281-294. doi:10.1038/tpj.2017.13

21. Dodgen TM, Labuschagne CDJ, van Schalkwyk A, Steffens FE, Gaedigk A, Cromarty AD, et al. Pharmacogenetic comparison of CYP2D6 predictive and measured phenotypes in a South African cohort. Pharmacogenomics J (2016) 16 (6)566-572. doi:10.1038/tpj.2015.76

22. Zhou $Y$, Ingelman-Sundberg $M$, Lauschke VM, Hočevar K, Maver A, Peterlin $\mathrm{B}$, et al. Worldwide Distribution of Cytochrome P450 Alleles: A Meta-analysis of Population-scale Sequencing Projects. Genet Med (2019) 21 (4)1345-1354. doi:10.1002/cpt.690

23. Drögemöller BI, Wright GE, Niehaus DJ, Koen L, Malan S, Da Silva DM, et al. Characterization of the genetic profile of CYP2C19 in two South African populations. Pharmacogenomics (2010) 11 (8)1095-1103. doi:10.2217/pgs. 10.90

24. Man M, Farmen M, Dumaual C, Teng CH, Moser B, Irie S, et al. Genetic Variation in Metabolizing Enzyme and Transporter Genes: Comprehensive Assessment in 3 Major East Asian Subpopulations With Comparison to Caucasians and Africans. J Clin Pharmacol (2010) 50 (8)929-940. doi:10.1177/0091270009355161

25. Wright GEB, Niehaus DJH, Drögemöller BI, Koen L, Gaedigk A, Warnich L. Elucidation of CYP2D6 Genetic Diversity in a Unique African Population: Implications for the Future Application of Pharmacogenetics in the Xhosa Population. Ann Hum Genet (2010) 74 (4)340-350. doi:10.1111/j.14691809.2010.00585.x

26. Kudzi W, Dodoo AN, Mills JJ. Characterisation of CYP2C8, CYP2C9 and CYP2C19 polymorphisms in a Ghanaian population. BMC Med Genet (2009) 10 (1)124. doi:10.1186/1471-2350-10-124

27. Miura J, Obua C, Abbo C, Kaneko S, Tateishi T. Cytochrome P450 2C19 
genetic polymorphisms in Ugandans. Eur J Clin Pharmacol (2009) 65 (3)319320. doi:10.1007/s00228-008-0583-6

28. Yen-Revollo JL, Van Booven DJ, Peters EJ, Hoskins JM, Engen RM, Kannall $\mathrm{HD}$, et al. Influence of ethnicity on pharmacogenetic variation in the Ghanaian population. Pharmacogenomics J (2009) 9 (6)373-379. doi:10.1038/tpj.2009.28

29. Gaedigk A, Coetsee C. The CYP2D6 gene locus in South African Coloureds: unique allele distributions, novel alleles and gene arrangements. Eur J Clin Pharmacol (2008) 64 (5)465-475. doi:10.1007/s00228-007-0445-7

30. Martis S, Peter I, Hulot J-S, Kornreich R, Desnick RJ, Scott SA. Multi-ethnic distribution of clinically relevant CYP2C genotypes and haplotypes. Pharmacogenomics J (2013) 13 (4)369-377. doi:10.1038/tpj.2012.10

31. Goldstein JA, Ishizaki T, Chiba K, de Morais SM, Bell D, Krahn PM, et al. Frequencies of the defective CYP2C19 alleles responsible for the mephenytoin poor metabolizer phenotype in various Oriental, Caucasian, Saudi Arabian and American black populations. Pharmacogenetics (1997) 7 (1)59-64. Available at: http://www.ncbi.nlm.nih.gov/pubmed/9110363

32. Budd WT, Meyers G, Dilts JR, O' K, Hanlon NA, Woody JR, et al. Next generation sequencing reveals disparate population frequencies among cytochrome P450 genes: clinical pharmacogenomics of the CYP2 family. Int J Comput Biol Drug Des (2016) 9 (1/2)54. doi:10.1504/IJCBDD.2016.074984

33. Cai W-M, Nikoloff DM, Pan R-M, de Leon J, Fanti P, Fairchild M, et al. CYP2D6 genetic variation in healthy adults and psychiatric African-American subjects: implications for clinical practice and genetic testing. Pharmacogenomics J (2006) 6 (5)343-350. doi:10.1038/sj.tpj.6500378

34. Luo H, Poland R, Lin K, Wan Y. Genetic polymorphism of cytochrome P450 2C19 in Mexican Americans: A cross-ethnic comparative study. Clin Pharmacol Ther (2006) 80 (1)33-40. doi:10.1016/j.clpt.2006.03.003

35. Gaedigk A, Bhathena A, Ndjountché L, Pearce RE, Abdel-Rahman SM, Alander SW, et al. Identification and characterization of novel sequence variations in the cytochrome P4502D6 (CYP2D6) gene in African Americans. Pharmacogenomics J (2005) 5 (3)173-182. doi:10.1038/sj.tpj.6500305

36. Melis R, Lyon E, McMillin GA. Determination of CYP2D6, CYP2C9 and CYP2C19 genotypes with Tag-It ${ }^{T M}$ mutation detection assays. Expert Rev Mol Diagn (2006) 6 (6)811-820. doi:10.1586/14737159.6.6.811

37. Gaedigk A, Bradford LD, Marcucci K a, Leeder JS. Unique CYP2D6 activity 


\section{Supplemental references}

distribution and genotype-phenotype discordance in black Americans. Clin Pharmacol Ther (2002) 72 (1)76-89. doi:10.1067/mcp.2002.125783

38. Wan Y-JY, Poland RE, Han G, Konishi T, Zheng Y-P, Berman N, et al. Analysis of the CYP2D6 gene polymorphism and enzyme activity in African-Americans in Southern California. Pharmacogenetics (2001) 11 (6)489-499. doi:10.1097/00008571-200108000-00004

39. Leathart JB, London SJ, Steward A, Adams JD, Idle JR, Daly AK. CYP2D6 phenotype-genotype relationships in African-Americans and Caucasians in Los Angeles. Pharmacogenetics (1998) 8 (6)529-41. Available at: http://www.ncbi.nlm.nih.gov/pubmed/9918137

40. Marinac JS, Balian JD, Foxworth JW, Willsie SK, Daus JC, Owen R, et al. Determination of CYP2C19 phenotype in black Americans with omeprazole: Correlation with genotype. Clin Pharmacol Ther (1996) 60 (2)138-144. doi:10.1016/S0009-9236(96)90129-0

41. Griman P, Moran Y, Valero G, Loreto M, Borjas L, Chiurillo MA. CYP2D6 gene variants in urban/admixed and Amerindian populations of Venezuela: Pharmacogenetics and anthropological implications. Ann Hum Biol (2012) 39 (2)137-142. doi:10.3109/03014460.2012.656703

42. Llerena A, Dorado P, Ramírez R, González I, Alvarez M, Peñas-Lledó EM, et al. CYP2D6 genotype and debrisoquine hydroxylation phenotype in Cubans and Nicaraguans. Pharmacogenomics J (2012) 12 (2)176-83. doi:10.1038/tpj.2010.85

43. Suarez-Kurtz G, Genro JP, de Moraes MO, Ojopi EB, Pena SDJ, Perini JA, et al. Global pharmacogenomics: Impact of population diversity on the distribution of polymorphisms in the CYP2C cluster among Brazilians. Pharmacogenomics J (2012) 12 (3)267-276. doi:10.1038/tpj.2010.89

44. Contreras A V, Monge-Cazares T, Alfaro-Ruiz L, Hernandez-Morales S, Miranda-Ortiz H, Carrillo-Sanchez K, et al. Resequencing, haplotype construction and identification of novel variants of CYP2D6 in Mexican Mestizos. Pharmacogenomics (2011) 12 (5)745-756. doi:10.2217/pgs.11.8

45. Sosa-Macías M, Dorado P, Alanis-Bañuelos RE, Llerena A, Lares-Asseff I. Influence of CYP2D6 Deletion, Multiplication, $-1584 C \rightarrow G, 31 G \rightarrow A$ and 2988G $\rightarrow$ A Gene Polymorphisms on Dextromethorphan Metabolism among Mexican Tepehuanos and Mestizos. Pharmacology (2010) 86 (1)30-36. doi:10.1159/000314334

46. Kohlrausch FB, Gama CS, Lobato MI, Belmonte-de-Abreu P, Gesteira A, 
Barros F, et al. Molecular diversity at the CYP2D6 locus in healthy and schizophrenic southern Brazilians. Pharmacogenomics (2009) 10 (9)14571466. doi:10.2217/pgs.09.76

47. Maciel ME, Oliveira FK, Propst GB, Bicalho MDG, Cavalli IJ, Ribeiro EMDSF. Population analysis of xenobiotic metabolizing genes in South Brazilian Euro and Afro-descendants. Genet Mol Biol (2009) 32 (4)723-728. doi:10.1590/S1415-47572009005000087

48. Perini JA, Vargens DD, Santana ISC, Moriguchi EH, Ribeiro-Dos-Santos AKC, Tsutsumi M, et al. Pharmacogenetic polymorphisms in Brazilian-born, firstgeneration Japanese descendants. Brazilian J Med Biol Res (2009) 42 (12)1179-84. doi:10.1590/s0100-879x2009001200010

49. Silveira VDS, Canalle R, Scrideli CA, Queiroz RGDP, Tone LG. Polymorphisms in genes encoding drugs and xenobiotic metabolizing enzymes in a Brazilian population. Biomarkers (2009) 14 (2)111-117. doi:10.1080/13547500902767294

50. Bailliet G, Santos MR, Alfaro EL, Dipierri JE, Demarchi DA, Carnese FR, et al. Allele and genotype frequencies of metabolic genes in Native Americans from Argentina and Paraguay. Mutat Res Toxicol Environ Mutagen (2007) 627 (2)171-177. doi:10.1016/j.mrgentox.2006.11.005

51. Isaza C, Henao J, Martínez JHI, Arias JCS, Beltrán L. Phenotype-genotype analysis of CYP2C19 in Colombian mestizo individuals. BMC Clin Pharmacol (2007) 7 (1)6. doi:10.1186/1472-6904-7-6

52. Bravo-Villalta H V., Yamamoto K, Nakamura K, Bayá A, Okada Y, Horiuchi R. Genetic polymorphism of CYP2C9 and CYP2C19 in a Bolivian population: an investigative and comparative study. Eur J Clin Pharmacol (2005) 61 (3)179184. doi:10.1007/s00228-004-0890-5

53. Luo H-R, Gaedigk A, Aloumanis V, Wan Y-JY. Identification of CYP2D6 impaired functional alleles in Mexican Americans. Eur J Clin Pharmacol (2005) 61 (11)797-802. doi:10.1007/s00228-005-0044-4

54. Isaza CA, Henao J, López AM, Cacabelos R. Isolation, sequence and genotyping of the drug metabolizer CYP2D6 gene in the Colombian population. Methods Find Exp Clin Pharmacol (2000) 22 (9)695-705. Available at: http://www.ncbi.nlm.nih.gov/pubmed/11294012

55. Jorge LF, Eichelbaum M, Griese EU, Inaba T, Arias TD. Comparative evolutionary pharmacogenetics of CYP2D6 in Ngawbe and Embera Amerindians of Panama and Colombia: role of selection versus drift in world 
populations. Pharmacogenetics (1999) 9 (2)217-28. doi:10376769

56. Muñoz S, Vollrath V, Vallejos MP, Miquel JF, Covarrubias C, Raddatz A, et al. Genetic polymorphisms of CYP2D6, CYP1A1 and CYP2E1 in the SouthAmerindian population of Chile. Pharmacogenetics (1998) 8 (4)343-51. Available at: http://www.ncbi.nlm.nih.gov/pubmed/9731721

57. Nowak MP, Sellers EM, Tyndale RF. Canadian Native Indians exhibit unique CYP2A6 and CYP2C19 mutant allele frequencies*. Clin Pharmacol Ther (1998) 64 (4)378-383. doi:10.1016/S0009-9236(98)90068-6

58. Agúndez JA, Ramirez R, Hernandez M, Llerena A, Benítez J. Molecular heterogeneity at the CYP2D gene locus in Nicaraguans: impact of gene-flow from Europe. Pharmacogenetics (1997) 7 (4)337-40. Available at: http://www.ncbi.nlm.nih.gov/pubmed/9295063

59. Jurima-Romet M, Foster BC, Casley WL, Rode A, Vloshinsky P, Huang HS, et al. CYP2D6-related oxidation polymorphism in a Canadian Inuit population. Can J Physiol Pharmacol (1997) 75 (3)165-172. doi:10.1139/y97-013

60. Nowak MP, Tyndale RF, Sellers EM. CYP2D6 phenotype and genotype in a Canadian Native Indian population. Pharmacogenetics (1997) 7 (2)145-8. Available at: http://www.ncbi.nlm.nih.gov/pubmed/9170152

61. Jurima-Romet $M$, Goldstein JA, LeBelle $M$, Aubin RA, Foster BC, Walop W, et al. CYP2C19 genotyping and associated mephenytoin hydroxylation polymorphism in a Canadian Inuit population. Pharmacogenetics (1996) 6 (4)329-39. Available at: http://www.ncbi.nlm.nih.gov/pubmed/8873219

62. Vicente J, González-Andrade F, Soriano A, Fanlo A, Martínez-Jarreta B, Sinués B. Genetic polymorphisms of CYP2C8, CYP2C9 and CYP2C19 in Ecuadorian Mestizo and Spaniard populations: a comparative study. Mol Biol Rep (2014) 41 (3)1267-1272. doi:10.1007/s11033-013-2971-y

63. Dorado P, Heras N, Machín E, Hernández F, Teran E, LLerena A. CYP2D6 genotype and dextromethorphan hydroxylation phenotype in an Ecuadorian population. Eur J Clin Pharmacol (2012) 68 (5)637-644. doi:10.1007/s00228011-1147-8

64. Salazar-Flores J, Torres-Reyes LA, Martínez-Cortés G, Rubi-Castellanos R, Sosa-Macías M, Muñoz-Valle JF, et al. Distribution of CYP2D6 and CYP2C19 Polymorphisms Associated with Poor Metabolizer Phenotype in Five Amerindian Groups and Western Mestizos from Mexico. Genet Test Mol Biomarkers (2012) 16 (9)1098-1104. doi:10.1089/gtmb.2012.0055

65. Vargens DD, Petzl-Erler M-L, Suarez-Kurtz G. Distribution of CYP2C 
Polymorphisms in an Amerindian Population of Brazil. Basic Clin Pharmacol Toxicol (2012) 110 (4)396-400. doi:10.1111/j.1742-7843.2011.00807.x

66. Chiurillo MA, Grimán P, Morán Y, Camargo ME, Ramírez JL. Analysis of CYP2D6 gene variation in Venezuelan population: Implications for forensic toxicology. Forensic Sci Int Genet Suppl Ser (2009) 2 (1)483-484. doi:10.1016/j.fsigss.2009.08.044

67. López M, Guerrero J, Jung-Cook H, Alonso ME. CYP2D6 genotype and phenotype determination in a Mexican Mestizo population. Eur J Clin Pharmacol (2005) 61 (10)749-754. doi:10.1007/s00228-005-0038-2

68. de Andrés F, Sosa-Macías M, Ramos BPL, Naranjo M-EG, LLerena A. CYP450 Genotype/Phenotype Concordance in Mexican Amerindian Indigenous Populations-Where to from Here for Global Precision Medicine?. Omi A J Integr Biol (2017) 21 (9)509-519. doi:10.1089/omi.2017.0101

69. Koopmans AB, Vinkers DJ, Gelan PJ, Hoek HW, van Harten PN. CYP2D6 and CYP2C19 genotyping in psychiatric patients on psychotropic medication in the former Dutch Antilles. Pharmacogenomics (2017) 18 (10)1003-1012. doi:10.2217/pgs-2017-0011

70. Acuña M, Pinto E, Olivares P, Ríos C. Genetic Variants of Cytochrome CYP2D6 in Two Mixed Chilean Populations. Hum Hered (2016) 82 (1-2)16-20. doi:10.1159/000478047

71. Céspedes-Garro C, Rodrigues-Soares F, Jiménez-Arce G, G. Naranjo M-E, Tarazona-Santos $\mathrm{E}$, Fariñas $\mathrm{H}$, et al. Relevance of the ancestry for the variability of the Drug-Metabolizing Enzymes CYP2C9, CYP2C19 and CYP2D6 polymorphisms in a multiethnic Costa Rican population. Rev Biol Trop (2016) 64 (3) doi:10.15517/rbt.v64i3.20901

72. De Andrés F, Terán S, Hernández F, Terán E, LLerena A. To genotype or phenotype for personalized medicine? CYP450 drug metabolizing enzyme genotype-phenotype concordance and discordance in the Ecuadorian population. Omi A J Integr Biol (2016) 20 (12)699-710. doi:10.1089/omi.2016.0148

73. Ortega-Vázquez A, Dorado P, Fricke-Galindo I, Jung-Cook H, MonroyJaramillo N, Martínez-Juárez IE, et al. CYP2C9, CYP2C19, ABCB1 genetic polymorphisms and phenytoin plasma concentrations in Mexican-Mestizo patients with epilepsy. Pharmacogenomics J (2016) 16 (3)286-292. doi:10.1038/tpj.2015.45

74. Saldaña-Cruz AM, León-Moreno LC, Sánchez-Corona J, Santiago DAM, 
Mendoza-Carrera F, Castro-Martínez XH, et al. CYP2C9 and CYP2C19 Allele and Haplotype Distributions in Four Mestizo Populations from Western Mexico: An Interethnic Comparative Study. Genet Test Mol Biomarkers (2016) 20 (11)702-709. doi:10.1089/gtmb.2016.0115

75. Varela N, Quiñones LA, Stojanova J, Garay J, Cáceres D, Cespedes S, et al. Characterization of the CYP2D6 drug metabolizing phenotypes of the Chilean mestizo population through polymorphism analyses. Pharmacol Res (2015) 101124-129. doi:10.1016/j.phrs.2015.07.020

76. Friedrich DC, Genro JP, Sortica VA, Suarez-Kurtz G, de Moraes ME, Pena SDJ, et al. Distribution of CYP2D6 Alleles and Phenotypes in the Brazilian Population. PLoS One (2014) 9 (10)e110691. doi:10.1371/journal.pone.0110691

77. López-López M, Peñas-Lledó E, Dorado P, Ortega A, Corona T, Ochoa A, et al. CYP2D6 genetic polymorphisms in Southern Mexican Mayan Lacandones and Mestizos from Chiapas. Pharmacogenomics (2014) 15 (15)1859-1865. doi:10.2217/pgs.14.139

78. Espinoza N, Galdames J, Navea D, Farfán MJ, Salas C. Frequency of the CYP2C19*17 polymorphism in a Chilean population and its effect on voriconazole plasma concentration in immunocompromised children. Sci Rep (2019) 9 (1)8863. doi:10.1038/s41598-019-45345-2

79. León-Moreno LC, Saldaña-Cruz AM, Sánchez-Corona J, Mendoza-Carrera F, García-Zapién AG, Revilla-Monsalve C, et al. Distribution of potential risk alleles and haplotypes of the CYP2C9 and CYP2C19 genes in Mexican native populations: A comparative study among Amerindian populations. Meta Gene (2019) 20100565. doi:10.1016/j.mgene.2019.100565

80. Favela-Mendoza AF, Martínez-Cortes G, Romero-Prado MM, Romero-Tejeda $\mathrm{EM}$, Islas-Carbajal MC, Sosa-Macias $\mathrm{M}$, et al. Correspondence between the CYP2C19 and CYP3A4 genotypes with the inferred metabolizer phenotype by omeprazole administration in Mexican healthy children. J Clin Pharm Ther (2018) 43 (5)656-663. doi:10.1111/jcpt.12699

81. Naranjo M-EG, Rodrigues-Soares F, Peñas-Lledó EM, Tarazona-Santos E, Fariñas $\mathrm{H}$, Rodeiro I, et al. Interethnic Variability in CYP2D6, CYP2C9, and CYP2C19 Genes and Predicted Drug Metabolism Phenotypes Among 6060 Ibero- and Native Americans: RIBEF-CEIBA Consortium Report on Population Pharmacogenomics. Omi A J Integr Biol (2018) 22 (9)575-588. doi:10.1089/omi.2018.0114

82. Kohlrausch FB, Carracedo Á, Hutz MH. Characterization of CYP1A2, 
CYP2C19, CYP3A4 and CYP3A5 polymorphisms in South Brazilians. Mol Biol Rep (2014) 41 (3)1453-1460. doi:10.1007/s11033-013-2990-8

83. Lazalde-Ramos BP, Martínez-Fierro MDLL, Galaviz-Hernández C, GarzaVeloz I, Naranjo MEG, Sosa-Macías M, et al. CYP2D6 gene polymorphisms and predicted phenotypes in eight indigenous groups from northwestern Mexico. Pharmacogenomics (2014) 15 (3)339-348. doi:10.2217/pgs.13.203

84. Fohner A, Muzquiz LI, Austin MA, Gaedigk A, Gordon A, Thornton T, et al. Pharmacogenetics in American Indian populations. Pharmacogenet Genomics (2013) 23 (8)403-414. doi:10.1097/FPC.0b013e3283629ce9

85. Montané Jaime LK, Lalla A, Steimer W, Gaedigk A. Characterization of the CYP2D6 gene locus and metabolic activity in Indo- and Afro-Trinidadians: discovery of novel allelic variants. Pharmacogenomics (2013) 14 (3)261-276. doi:10.2217/pgs.12.207

86. Suwannasri $P$, Thongnoppakhun W, Pramyothin P, Assawamakin A, Limwongse C. Combination of multiplex PCR and DHPLC-based strategy for CYP2D6 genotyping scheme in Thais. Clin Biochem (2011) 44 (13)1144-1152. doi:10.1016/j.clinbiochem.2011.06.985

87. Kim E, Lee $\mathrm{S}$, Jung $\mathrm{H}-\mathrm{J}$, Jung $\mathrm{H}$, Yeo $\mathrm{C}$, Shon J, et al. Robust CYP2D6 genotype assay including copy number variation using multiplex single-base extension for Asian populations. Clin Chim Acta (2010) 411 (23-24)2043-2048. doi:10.1016/j.cca.2010.08.042

88. Veiga MI, Asimus S, Ferreira PE, Martins JP, Cavaco I, Ribeiro V, et al. Pharmacogenomics of CYP2A6, CYP2B6, CYP2C 19, CYP2D6, CYP3A4, CYP3A5 and MDR1 in Vietnam. Eur J Clin Pharmacol (2009) 65 (4)355-363. doi:10.1007/s00228-008-0573-8

89. Ghodke Y, Joshi K, Arya Y, Radkar A, Chiplunkar A, Shintre P, et al. Genetic polymorphism of CYP2C19 in Maharashtrian population. Eur J Epidemiol (2007) 22 (12)907-915. doi:10.1007/s10654-007-9196-0

90. Lee SS, Lee S-J, Gwak J, Jung H-J, Thi-Le H, Song I-S, et al. Comparisons of CYP2C19 Genetic Polymorphisms Between Korean and Vietnamese Populations. Ther Drug Monit (2007) 29 (4)455-459. doi:10.1097/FTD.0b013e31811f383c

91. Tassaneeyakul W, Mahatthanatrakul W, Niwatananun K, Na-Bangchang K, Tawalee A, Krikreangsak N, et al. CYP2C19 Genetic Polymorphism in Thai, Burmese and Karen Populations. Drug Metab Pharmacokinet (2006) 21 (4)286-290. doi:10.2133/dmpk.21.286 
92. Jose R, Chandrasekaran A, Sam SS, Gerard N, Chanolean S, Abraham BK, et al. CYP2C9 and CYP2C19 genetic polymorphisms: frequencies in the south Indian population. Fundam Clin Pharmacol (2005) 19 (1)101-105. doi:10.1111/j.1472-8206.2004.00307.x

93. Yang YS, Wong LP, Lee TC, Mustafa AM, Mohamed Z, Lang CC. Genetic polymorphism of cytochrome P450 2C19 in healthy Malaysian subjects. $\mathrm{Br} J$ Clin Pharmacol (2004) 58 (3)332-335. doi:10.1111/j.1365-2125.2004.02144.x

94. Adithan C, Gerard N, Vasu S, Rosemary J, Shashindran CH, Krishnamoorthy $\mathrm{R}$. Allele and genotype frequency of CYP2C19 in a Tamilian population. $\mathrm{Br} \mathrm{J}$ Clin Pharmacol (2003) 56 (3)331-333. doi:10.1046/j.1365-2125.2003.01883.x

95. Tassaneeyakul W, Tawalee A, Tassaneeyakul W, Kukongviriyapan V, Blaisdell $\mathrm{J}$, Goldstein JA, et al. Analysis of the CYP2C19 polymorphism in a Northeastern Thai population. Pharmacogenetics (2002) 12 (3)221-225. doi:10.1097/00008571-200204000-00006

96. Ismail R, Teh LK, Amir J, Alwi Z, Lopez CG. Genetic polymorphism of CYP2D6 in Chinese subjects in Malaysia. J Clin Pharm Ther (2003) 28 (4)279-84. Available at: http://www.ncbi.nlm.nih.gov/pubmed/12911679

97. Teh LK, Ismail R, Yusoff R, Hussein A, Isa MN, Rahman ARA. Heterogeneity of the CYP2D6 gene among Malays in Malaysia. J Clin Pharm Ther (2001) 26205-211.

98. Gulati S, Yadav A, Kumar N, Kanupriya, Kumar G, Aggarwal N, et al. Frequency distribution of high risk alleles of CYP2C19, CYP2E1, CYP3A4 genes in Haryana population. Environ Toxicol Pharmacol (2014) 37 (3)1186-1193. doi:10.1016/j.etap.2014.03.013

99. Baclig MO, Predicala RZ, Mapua CA, Lozano-Kühne JP, Daroy MLG, Natividad FF, et al. Allelic and genotype frequencies of catechol-Omethyltransferase (Val158Met) and CYP2D6*10 (Pro34Ser) single nucleotide polymorphisms in the Philippines. Int J Mol Epidemiol Genet (2012) 3 (2)11521. Available at: http://www.ncbi.nlm.nih.gov/pubmed/22724048

100. Siddapuram SP, Banerjee R, Tandan M, Prathap N, Mitnal S, Duvvuru NR. CYP2C19 polymorphism as a predictor of personalized therapy in South Indian population. J Assoc Physicians India (2011) 59490-3. Available at: http://www.ncbi.nlm.nih.gov/pubmed/21887904 
101. Sistonen J, Fuselli S, Palo JU, Chauhan N, Padh H, Sajantila A.

Pharmacogenetic variation at CYP2C9, CYP2C19, and CYP2D6 at global and microgeographic scales. Pharmacogenet Genomics (2009) 19 (2)170-179. doi:10.1097/FPC.0b013e32831ebb30

102. Majumdar S, Mondal BC, Ghosh M, Dey S, Mukhopadhyay A, Chandra S, et al. Association of cytochrome P450, glutathione S-transferase and N-acetyl transferase 2 gene polymorphisms with incidence of acute myeloid leukemia. Eur J Cancer Prev (2008) 17 (2)125-132. doi:10.1097/CEJ.0b013e3282b6fd68

103. Singh $M$, Khan A, Shah P, Shukla R, Khanna V, Parmar D. Polymorphism in environment responsive genes and association with Parkinson disease. Mol Cell Biochem (2008) 312131-138. doi:10.1007

104. Naveen AT, Adithan C, Soya SS, Gerard N, Krishnamoorthy R. CYP2D6 Genetic Polymorphism in South Indian Populations. Biol Pharm Bull (2006) 29 (8)1655-1658. doi:10.1248/bpb.29.1655

105. Buch S, Kotekar A, Kawle D, Bhisey R. Polymorphisms at CYP and GST gene loci. Prevalence in the Indian population. Eur J Clin Pharmacol (2001) 57 (67)553-5. Available at: http://www.ncbi.nlm.nih.gov/pubmed/11699625

106. Weerasuriya K, Jayakody R, Smith C, Wolf C, Tucker G, Lennard M. Debrisoquine and mephenytoin oxidation in Sinhalese: a population study. $\mathrm{Br}$ J Clin Pharmacol (1994) 38 (5)466-470. doi:10.1111/j.13652125.1994.tb04384.x

107. Deshpande N, V. S, V. V. RK, H. V. V. M, M. S, Banerjee R, et al. Rapid and ultra-rapid metabolizers with CYP2C19 *17 polymorphism do not respond to standard therapy with proton pump inhibitors. Meta Gene (2016) 9 (8)159164. doi:10.1016/j.mgene.2016.06.004

108. Sridharan K, Kataria R, Tolani D, Bendkhale S, Gogtay N, Thatte U. Evaluation of CYP2C19, P2Y12, and ABCB1 polymorphisms and phenotypic response to clopidogrel in healthy Indian adults. Indian J Pharmacol (2016) 48 (4)350. doi:10.4103/0253-7613.186191

109. Ayyappadhas $\mathrm{R}$, Dhanalekshmi U, Jestin C. CYP 2D6*4 polymorphism and interindividual response variation to metoprolol instage 1 hypertensive patients: no association in a rural Indian population?. Turkish J Med Sci (2015) 45352-357. doi:10.3906/sag-1307-133 
110. Choudhury S, Akam E, Mastana S. Genetic Analysis of CYP2D6 Polymorphism in Indian Populations and its Pharmacogenetic Implications. Curr Pharmacogenomics Person Med (2014) 12 (2)123-132. doi:10.2174/1875692112666140908231649

111. Afsar NA, Bruckmueller H, Werk AN, Nisar MK, Ahmad HR, Cascorbi I. Implications of genetic variation of common Drug Metabolizing Enzymes and ABC Transporters among the Pakistani Population. Sci Rep (2019) 9 (1)7323. doi:10.1038/s41598-019-43736-z

112. Nguyen HH, Ma TTH, Vu NP, Bach QTN, Vu TH, Nguyen TD, et al. Single nucleotide and structural variants of CYP2D6 gene in Kinh Vietnamese population. Medicine (Baltimore) (2019) 98 (22)e15891. doi:10.1097/MD.0000000000015891

113. Riaz S, Muhammad Din S, Usman Tareen M, Tariq F, Latif $Y$, Siddiqi S, et al. Genetic Polymorphism of CYP2C19 in Pakistani Population. Iran J Pharm Res (2019) 18 (2)1097-1102. doi:10.22037/ijpr.2019.1100644

114. Bhat MA, Gandhi G. CYP2D6 (C2850T, G1846A, C100T) polymorphisms, haplotypes and MDR analysis in predicting coronary artery disease risk in north-west Indian population: A case-control study. Gene (2018) 663 (October 2017)17-24. doi:10.1016/j.gene.2018.04.008

115. Paradkar MU, Shah SAV, Dherai AJ, Shetty D, Ashavaid TF. Distribution of CYP2D6 genotypes in the Indian population - preliminary report. Drug Metab Pers Ther (2018) 33 (3)141-151. doi:10.1515/dmpt-2018-0011

116. Riaz S, Mansoor A, Siddiqi S, Tareen MU, Batool A, Sultan A. Association of CYP2C19 * 2 and * 17 genetic variants with hypertension in Pakistani population. Trop J Pharm Res (2019) 18 (April)851-855. doi:10.4314/tjpr.v18i4.24

117. Singh H, Lata S, Gangakhedkar RR. Prevalence of CYP2D6 * 4 1934G / A polymorphism in Western Indian HIV patients. J Pathol Microbiol Immunol (2018) 126842-851. doi:10.1111/apm.12893

118. Shalia KK, Shah VK, Pawar P, Divekar SS, Payannavar S. Polymorphisms of MDR1, CYP2C19 and P2Y12 genes in Indian population: Effects on clopidogrel response. Indian Heart J (2013) 65 (2)158-167. doi:10.1016/j.ihj.2013.02.012

119. Anichavezhi D, Chakradhara Rao US, Shewade DG, Krishnamoorthy R, Adithan C. Distribution of CYP2C19*17 allele and genotypes in an Indian population. J Clin Pharm Ther (2012) 37 (3)313-318. doi:10.1111/j.13652710.2011.01294.x 
120. Xiuchun Y, Fan L, Jingchao L, Bing X, Wei C. GW24-e1197 Allele and genotype frequencies of CYP2C19 in Chinese Han population. Heart (2013) 99 (Suppl 3)e128. doi:10.1136/heartjnl-2013-304613.347

121. Jin T, Ma L, Zhang J, Yuan D, Sun Q, Zong T, et al. Polymorphisms and phenotypic analysis of cytochrome P450 2D6 in the Tibetan population. Gene (2013) 527 (1)360-365. doi:10.1016/j.gene.2013.03.110

122. Shin D-J, Kwon J, Park A-R, Bae Y, Shin E, Park S, et al. Association of CYP2C19*2 and *3 Genetic Variants with Essential Hypertension in Koreans. Yonsei Med J (2012) 53 (6)1113. doi:10.3349/ymj.2012.53.6.1113

123. Yin S-J, Ni Y-B, Wang S-M, Wang X, Lou Y-Q, Zhang G-L. Differences in genotype and allele frequency distributions of polymorphic drug metabolizing enzymes CYP2C19 and CYP2D6 in mainland Chinese Mongolian, Hui and Han populations. J Clin Pharm Ther (2012) 37 (3)364-369. doi:10.1111/j.1365-2710.2011.01298.x

124. Zuo J, Xia D, Jia L, Guo T. Genetic polymorphisms of drug-metabolizing phase I enzymes CYP3A4, CYP2C9, CYP2C19 and CYP2D6 in Han, Uighur, Hui and Mongolian Chinese populations. Pharmazie (2011) 67 (7)639-644. doi:10.1691/ph.2012.1735

125. Ramsjö M, Aklillu E, Bohman L, Ingelman-Sundberg M, Roh H-K, Bertilsson L. CYP2C19 activity comparison between Swedes and Koreans: effect of genotype, sex, oral contraceptive use, and smoking. Eur J Clin Pharmacol (2010) 66 (9)871-877. doi:10.1007/s00228-010-0835-0

126. Kim KA, Song WK, Park JY. Association of CYP2B6, CYP3A5, and CYP2C19 Genetic Polymorphisms With Sibutramine Pharmacokinetics in Healthy Korean Subjects. Clin Pharmacol Ther (2009) 86 (5)511-518. doi:10.1038/clpt.2009.145

127. Lee S-J, Lee SS, Jung H-J, Kim H-S, Park S-J, Yeo C-W, et al. Discovery of Novel Functional Variants and Extensive Evaluation of CYP2D6 Genetic Polymorphisms in Koreans. Drug Metab Dispos (2009) 37 (7)1464-1470. doi:10.1124/dmd.108.022368

128. Wang S-M, Zhu A-P, Li D, Wang Z, Zhang P, Zhang G-L. Frequencies of genotypes and alleles of the functional SNPs in CYP2C19 and CYP2E1 in mainland Chinese Kazakh, Uygur and Han populations. J Hum Genet (2009) 54 (6)372-375. doi:10.1038/jhg.2009.41

129. Zhou Q, Yu XM, Lin HB, Wang L, Yun QZ, Hu SN, et al. Genetic polymorphism, linkage disequilibrium, haplotype structure and novel allele 


\section{Supplemental references}

analysis of CYP2C19 and CYP2D6 in Han Chinese. Pharmacogenomics J (2009) 9 (6)380-394. doi:10.1038/tpj.2009.31

130. Chen L, Qin S, Xie J, Tang J, Yang L, Shen W, et al. Genetic polymorphism analysis of CYP2C19 in Chinese Han populations from different geographic areas of mainland China. Pharmacogenomics (2008) 9 (6)691-702. doi:10.2217/14622416.9.6.691

131. Myrand S, Sekiguchi K, Man M, Lin X, Tzeng R-Y, Teng C-H, et al. Pharmacokinetics/Genotype Associations for Major Cytochrome P450 Enzymes in Native and First- and Third-generation Japanese Populations: Comparison With Korean, Chinese, and Caucasian Populations. Clin Pharmacol Ther (2008) 84 (3)347-361. doi:10.1038/sj.clpt.6100482

132. Qin S, Shen L, Zhang A, Xie J, Shen W, Chen L, et al. Systematic polymorphism analysis of the CYP2D6 gene in four different geographical Han populations in mainland China. Genomics (2008) 92 (3)152-158. doi:10.1016/j.ygeno.2008.05.004

133. Sugimoto $\mathrm{K}$, Uno $\mathrm{T}$, Yamazaki $\mathrm{H}$, Tateishi T. Limited frequency of the CYP2C19*17 allele and its minor role in a Japanese population. Br J Clin Pharmacol (2008) 65 (3)437-439. doi:10.1111/j.1365-2125.2007.03057.x

134. Cai WM, Chen B, Zhang WX. Frequency of CYP2D 6*10 and * 14 Alleles and their Influence on the Metabolic Activity of CYP2D6 in a Healthy Chinese Population. Clin Pharmacol Ther (2007) 81 (1)95-98. doi:10.1038/sj.clpt.6100015

135. Ishii G, Suzuki A, Oshino S, Shiraishi H, Otani K. CYP2C19 polymorphism affects personality traits of Japanese females. Neurosci Lett (2007) 411 (1)7780. doi:10.1016/j.neulet.2006.10.012

136. Iwashima K, Yasui-Furukori N, Kaneda A, Saito M, Nakagami T, Sato Y, et al. No association between CYP2D6 polymorphisms and personality trait in Japanese. Br J Clin Pharmacol (2007) 64 (1)96-99. doi:10.1111/j.13652125.2007.02858.x

137. Sheng $\mathrm{H}-\mathrm{H}$, Zeng A-P, Zhu W-X, Zhu R-F, Li H-M, Zhu Z-D, et al. Allelic distributions of CYP2D6 gene copy number variation in the Eastern Han Chinese population. Acta Pharmacol Sin (2007) 28 (2)279-286. doi:10.1111/j.1745-7254.2007.00479.x

138. Lee S-Y, Sohn KM, Ryu JY, Yoon YR, Shin JG, Kim J. Sequence-based CYP2D6 Genotyping in the Korean Population. Ther Drug Monit (2006) 28 (3)382-387. doi:10.1097/01.ftd.0000211823.80854.db 
139. Liou Y-H, Lin C-T, Wu Y-J, Wu LS-H. The high prevalence of the poor and ultrarapid metabolite alleles of CYP2D6, CYP2C9, CYP2C19, CYP3A4, and CYP3A5 in Taiwanese population. J Hum Genet (2006) 51 (10)857-863. doi:10.1007/s10038-006-0034-0

140. Fukushima-Uesaka H, Saito Y, Maekawa K, Ozawa S, Hasegawa R, Kajio H, et al. Genetic variations and haplotypes of CYP2C19 in a Japanese population. Drug Metab Pharmacokinet (2005) 20 (4)300-7. Available at: http://www.ncbi.nlm.nih.gov/pubmed/16141610

141. Ikenaga $Y$, Fukuda T, Fukuda $\mathrm{K}$, Nishida $\mathrm{Y}$, Naohara $\mathrm{M}$, Maune $\mathrm{H}$, et al. The Frequency of Candidate Alleles for CYP2D6 Genotyping in the Japanese Population with an Additional Respect to the $-1584 \mathrm{C}$ to $\mathrm{G}$ Substitution. Drug Metab Pharmacokinet (2005) 20 (2)113-116. doi:10.2133/dmpk.20.113

142. Ji L, Pan S, Marti-Jaun J, Hänseler E, Rentsch K, Hersberger M. Single-step assays to analyze CYP2D6 gene polymorphisms in Asians: allele frequencies and a novel *74B allele in mainland Chinese. Clin Chem (2002) 48 (7)983-8. Available at: http://www.ncbi.nlm.nih.gov/pubmed/12089164

143. Mitsunaga $Y$, Kubota T, Ishiguro A, Yamada $Y$, Sasaki H, Chiba K, et al. Frequent occurrence of CYP2D $6 * 10$ duplication allele in a Japanese population. Mutat Res Mol Mech Mutagen (2002) 505 (1-2)83-85. doi:10.1016/S0027-5107(02)00122-7

144. Kimura M, leiri I, Mamiya K, Urae A, Higuchi S. Genetic polymorphism of cytochrome P450s, CYP2C19, and CYP2C9 in a Japanese population. Ther Drug Monit (1998) 20 (3)243-7. Available at: http://www.ncbi.nlm.nih.gov/pubmed/9631918

145. Xiao ZS, Goldstein JA, Xie HG, Blaisdell J, Wang W, Jiang $\mathrm{CH}_{\text {, et al. }}$ Differences in the incidence of the CYP2C19 polymorphism affecting the Smephenytoin phenotype in Chinese Han and Bai populations and identification of a new rare CYP2C19 mutant allele. J Pharmacol Exp Ther (1997) 281 (1)604-9. Available at: http://www.ncbi.nlm.nih.gov/pubmed/9103550

146. Kubota T, Chiba K, Ishizaki T. Genotyping of S-mephenytoin 4'-hydroxylation in an extended Japanese population. Clin Pharmacol Ther (1996) 60 (6)661-6. doi:10.1016/S0009-9236(96)90214-3

147. Roh HK, Dahl ML, Tybring G, Yamada H, Cha YN, Bertilsson L. CYP2C19 genotype and phenotype determined by omeprazole in a Korean population. Pharmacogenetics (1996) 6 (6)547-51. Available at: http://www.ncbi.nlm.nih.gov/pubmed/9014204 


\section{Supplemental references}

148. Roh HK, Dahl ML, Johansson I, Ingelman-Sundberg M, Cha YN, Bertilsson L. Debrisoquine and S-mephenytoin hydroxylation phenotypes and genotypes in a Korean population. Pharmacogenetics (1996) 6 (5)441-7. Available at: http://www.ncbi.nlm.nih.gov/pubmed/8946476

149. Li J, Wang X, Zhang Z, Chen Y, Zou J, Wang X, et al. Correlation between CYP2D6*10 Gene Mutation, and Structure and Function of its Encoding Prot. Trop J Pharm Res (2014) 13 (3)347. doi:10.4314/tjpr.v13i3.5

150. Yan F, Xu J-F, Liu X, Li X-H. Interaction between smoking and CYP2C19*3 polymorphism increased risk of lung cancer in a Chinese population. Tumor Biol (2014) 35 (6)5295-5298. doi:10.1007/s13277-014-1689-3

151. Chan SW, Hu M, Ko SSW, Tam CWY, Fok BSP, Yin OQP, et al. CYP2C19 genotype has a major influence on labetalol pharmacokinetics in healthy male Chinese subjects. Eur J Clin Pharmacol (2013) 69 (4)799-806. doi:10.1007/s00228-012-1428-x

152. Qian J-C, Xu X-M, Hu G-X, Dai D-P, Xu R-A, Hu L-M, et al. Genetic variations of human CYP2D6 in the Chinese Han population. Pharmacogenomics (2013) 14 (14)1731-1743. doi:10.2217/pgs.13.160

153. Wu Z, Zhang X, Shen L, Xiong Y, Wu X, Huo R, et al. A Systematically Combined Genotype and Functional Combination Analysis of CYP2E1, CYP2D6, CYP2C9, CYP2C19 in Different Geographic Areas of Mainland China - A Basis for Personalized Therapy. PLoS One (2013) 8 (10) doi:10.1371/journal.pone.0071934

154. Hu L-M, Dai D-P, Hu G-X, Yang J-F, Xu R-A, Yang L-P, et al. Genetic polymorphisms and novel allelic variants of CYP2C19 in the Chinese Han population. Pharmacogenomics (2012) 13 (14)1571-1581. doi:10.2217/pgs.12.141

155. Okubo M, Murayama N, Miura J, Shimizu M, Yamazaki H. A rapid multiplex $P C R$ assay that can reliably discriminate the cytochrome P450 2D6 wholegene deletion allele from 2D6*10 alleles. Clin Chim Acta (2012) 413 (1920)1675-1677. doi:10.1016/j.cca.2012.05.013

156. Shao H, Ren XM, Liu NF, Chen GM, Li WL, Zhai ZH, et al. Influence of CYP2C9 and CYP2C19 genetic polymorphisms on pharmacokinetics and pharmacodynamics of gliclazide in healthy Chinese Han volunteers. J Clin Pharm Ther (2010) 35 (3)351-360. doi:10.1111/j.1365-2710.2009.01134.x

157. Yang Y-N, Wang X-L, Ma Y-T, Xie X, Fu Z-Y, Li X-M, et al. Association of Interaction Between Smoking and CYP 2C19*3 Polymorphism With Coronary 
Artery Disease in a Uighur Population. Clin Appl Thromb (2010) 16 (5)579583. doi:10.1177/1076029610364522

158. Yang ZF, Cui HW, Hasi T, Jia SQ, Gong ML, Su XL. Genetic polymorphisms of cytochrome P450 enzymes 2C9 and 2C19 in a healthy Mongolian population in China. Genet Mol Res (2010) 9 (3)1844-1851. doi:10.4238/vol9-3gmr938

159. Yoo HD, Park SA, Cho HY, Lee YB. Influence of CYP3A and CYP2C19 genetic polymorphisms on the pharmacokinetics of cilostazol in healthy subjects. Clin Pharmacol Ther (2009) 86 (3)281-284. doi:10.1038/clpt.2009.90

160. Otani K, Ujike H, Sakai A, Okahisa Y, Kotaka T, Inada T, et al. Reduced CYP2D6 activity is a negative risk factor for methamphetamine dependence. Neurosci Lett (2008) 434 (1)88-92. doi:10.1016/j.neulet.2008.01.033

161. Kato D, Kawanishi C, Kishida I, Furuno T, Suzuki K, Onishi $H$, et al. Effects of CYP2D6 polymorphisms on neuroleptic malignant syndrome. Eur J Clin Pharmacol (2007) 63 (11)991-996. doi:10.1007/s00228-007-0355-8

162. Wang J-H, Li P-Q, Fu Q-Y, Li Q-X, Cai W-W. CYP2C19 genotype and omeprazole hydroxylation phenotype in Chinese Li population. Clin Exp Pharmacol Physiol (2007) 34 (5-6)421-424. doi:10.1111/j.14401681.2007.04583.x

163. Kim M-K, Cho J-Y, Lim H-S, Hong K-S, Chung J-Y, Bae K-S, et al. Effect of the CYP2D6 genotype on the pharmacokinetics of tropisetron in healthy Korean subjects. Eur J Clin Pharmacol (2003) 59 (2)111-116. doi:10.1007/s00228003-0595-1

164. Ling J, Shixiu P, Jianmin W, Marti-Jaun J, Hersberger M. Genetic polymorphism of CYP2D6 in Chinese mainland. Chin Med J (Engl) (2002) 115 (12)1780-1784. Available at:

http://www.ncbi.nlm.nih.gov/pubmed/12911679

165. Ohkubo T, Suno M, Sugawara K, Motomuro S. Graphic Roots of CYP2C19 genetic polymorphism in Japanese population (preliminary report). Int Congr Ser (2002) 124463-67.

166. Tateishi T. Analysis of the CYP2D6 gene in relation to its metabolic capacity in Japanese men and in comparison with other populations. Int Congr Ser (2002) 124433-39. 
167. Chida M, Yokoi T, Nemoto N, Inaba M, Kinoshita M, Kamataki T. A new variant CYP2D6 allele (CYP2D6*21) with a single base insertion in exon 5 in a Japanese population associated with a poor metabolizer phenotype. Pharmacogenetics (1999) 9 (3)287-93. Available at: http://www.ncbi.nlm.nih.gov/pubmed/10471060

168. Tateishi T, Chida M, Ariyoshi N, Mizorogi Y, Kamataki T, Kobayashi S. Analysis of the gene in relation to dextromethorphan -demethylation capacity in a Japanese population. Clin Pharmacol Ther (1999) 65 (5)570-575. doi:10.1016/S0009-9236(99)70077-9

169. Takakubo F, Kuwano A, Kondo I. Evidence that poor metabolizers of (S)mephenytoin could be identified by haplotypes of CYP2C19 in Japanese. Pharmacogenetics (1996) 6 (3)265-267. doi:10.1097/00008571-19960600000011

170. Tsuneoka Y, Fukushima K, Matsuo Y, Ichikawa Y, Watanabe Y. Genotype analysis of the CYP2C19 gene in the Japanese population. Life Sci (1996) 59 (20)1711-5. Available at: http://www.ncbi.nlm.nih.gov/pubmed/8890945

171. Akasaka T, Hokimoto S, Sueta D, Tabata N, Sakamoto K, Yamamoto E, et al. Sex differences in the impact of CYP2C19 polymorphisms and low-grade inflammation on coronary microvascular disorder. Am J Physiol Circ Physiol (2016) 310 (11)H1494-H1500. doi:10.1152/ajpheart.00911.2015

172. Jeon J-Y, Chae S-W, Kim M-G. Population pharmacokinetics of aripiprazole in healthy Korean subjects. Int J Clin Pharmacol Ther (2016) 54 (4)293-304. doi:10.5414/CP202466

173. Jin T, Zhang X, Geng T, Shi X, Wang L, Yuan D, et al. Genotype-phenotype analysis of CYP2C19 in the Tibetan population and its potential clinical implications in drug therapy. Mol Med Rep (2016) 13 (3)2117-2123. doi:10.3892/mmr.2016.4776

174. Chen R, Wang H, Shi J, Shen K, Hu P. Cytochrome P450 2D6 genotype affects the pharmacokinetics of controlled-release paroxetine in healthy Chinese subjects: comparison of traditional phenotype and activity score systems. Eur J Clin Pharmacol (2015) 71 (7)835-841. doi:10.1007/s00228-015-1855-6

175. Cho D-Y, Bae SH, Lee JK, Park JB, Kim Y-W, Lee S, et al. Effect of the potent CYP2D6 inhibitor sarpogrelate on the pharmacokinetics and pharmacodynamics of metoprolol in healthy male Korean volunteers. Xenobiotica (2015) 45 (3)256-263. doi:10.3109/00498254.2014.967824

176. Ding Y, Xu D, Zhang X, Yang H, Geng T, He P, et al. Genetic polymorphisms 
and phenotypic analysis of drug-metabolizing enzyme CYP2C19 in a $\mathrm{Li}$ Chinese population. Int J Clin Exp Pathol (2015) 8 (10)13201-8. Available at: http://www.ncbi.nlm.nih.gov/pubmed/26722519

177. Dong Y, Xiao H, Wang Q, Zhang C, Liu X, Yao N, et al. Analysis of genetic variations in CYP2C9, CYP2C19, CYP2D6 and CYP3A5 genes using oligonucleotide microarray. Int J Clin Exp Med (2015) 8 (10)18917-26. Available at: http://www.ncbi.nlm.nih.gov/pubmed/26770516

178. Hokimoto S, Tabata N, Akasaka T, Arima Y, Kaikita K, Morita K, et al. Gender Differences in Impact of CYP2C19 Polymorphism on Development of Coronary Artery Disease. J Cardiovasc Pharmacol (2014) 65 (2)1. doi:10.1097/FJC.0000000000000171

179. Jin T, Zhang M, Yang H, Geng T, Zhang N, Feng T, et al. Genetic polymorphisms of the drug-metabolizing enzyme CYP2C19 in the Uyghur population in northwest China. Xenobiotica (2016) 46 (7)634-640. doi:10.3109/00498254.2015.1102986

180. Moon SJ, Yoon J, Oh J, Lee S, Yu K-S. Population Pharmacokinetics of Voriconazole in Healthy Korean Male with Various CYP2C19 Genotypes. J Pharmacokinet Pharmacodyn (2015) 42759.

181. Li J, Wang X, Zhang Z, Zou J, Chen Y, Wang X, et al. Statin therapy correlated CYP2D6 gene polymorphism and hyperlipidemia. Curr Med Res Opin (2014) 30 (2)223-228. doi:10.1185/03007995.2013.858619

182. Zhong Z, Hou J, Li B, Zhang Q, Liu S, Li C, et al. Analysis of CYP2C19 Genetic Polymorphism in a Large Ethnic Hakka Population in Southern China. Med Sci Monit (2017) 236186-6192. Available at: http://www.ncbi.nlm.nih.gov/pubmed/29288619

183. Lee J, Yoo H-D, Bae J-W, Lee S, Shin K-H. Population pharmacokinetic analysis of tramadol and O-desmethyltramadol with genetic polymorphism of CYP2D6. Drug Des Devel Ther (2019) Volume 131751-1761. doi:10.2147/DDDT.S199574

184. Byeon J-Y, Kim Y-H, Lee C-M, Kim S-H, Chae W-K, Jung E-H, et al. CYP2D6 allele frequencies in Korean population, comparison with East Asian, Caucasian and African populations, and the comparison of metabolic activity of CYP2D6 genotypes. Arch Pharm Res (2018) 41 (9)921-930. doi:10.1007/s12272-018-1075-6 
185. Cao P, Zhao Q, Shao Y, Yang H, Jin T, Li B, et al. Genetic polymorphisms of the drug-metabolizing enzyme CYP2J2 in a Tibetan population. Medicine (Baltimore) (2018) 97 (40)e12579. doi:10.1097/MD.0000000000012579

186. Jung E, Ryu S, Park Z, Lee J-G, Yi J-Y, Seo DW, et al. Influence of CYP2D6 Polymorphism on the Pharmacokinetic/Pharmacodynamic Characteristics of Carvedilol in Healthy Korean Volunteers. J Korean Med Sci (2018) 33 (27)112. doi:10.3346/jkms.2018.33.e182

187. Jakovski K, Nestorovska AK, Labacevski N, Dimovski AJ. Characterization of the most common CYP2C9 and CYP2C19 allelic variants in the population from the Republic of Macedonia. Pharmazie (2013) 68 (11)893-8. doi:24380239

188. Sipeky C, Weber A, Szabo M, Melegh BI, Janicsek I, Tarlos G, et al. High prevalence of CYP2C19*2 allele in Roma samples: study on Roma and Hungarian population samples with review of the literature. Mol Biol Rep (2013) 40 (8)4727-4735. doi:10.1007/s11033-013-2569-4

189. Korchagina RP, Osipova LP, Vavilova NA, Ermolenko NA, Voronina EN, Filipenko ML. Polymorphisms of the GSTM1, GSTT1, and CYP2D6 xenobiotic biotransformation genes, which are possible risk markers of cancer in populations of indigenous ethnic groups and Russians of North Siberia. Russ J Genet Appl Res (2012) 2 (1)7-17. doi:10.1134/S2079059712010091

190. Scott SA, Martis S, Peter I, Kasai Y, Kornreich R, Desnick RJ. Identification of CYP2C19*4B: Pharmacogenetic implications for drug metabolism including clopidogrel responsiveness. Pharmacogenomics J (2012) 12 (4)297-305. doi:10.1038/tpj.2011.5

191. Stingl JC, Esslinger C, Tost H, Bilek E, Kirsch P, Ohmle B, et al. Genetic variation in CYP2D6 impacts neural activation during cognitive tasks in humans. Neuroimage (2012) 59 (3)2818-2823.

doi:10.1016/j.neuroimage.2011.07.052

192. Buzoianu AD, Trifa AP, Popp RA, Militaru MS, Militaru CF, Bocşan Cl, et al. Screening for CYP2C19*2, *3 AND *4 gene variants in a Romanian population study group. Farmacia (2010) 58 (6)806-817.

193. Fernández-Santander A, Luna F, Santiago C, Rodríguez MT, Bandrés F, Ruiz $J \mathrm{R}$, et al. CYP2D6 polymorphism screening in a selected population of Spain (La Alpujarra): No effect of geographical isolation. Ann Hum Biol (2010) 37 (2)268-274. doi:10.3109/03014460903051658

194. Gra O, Mityaeva O, Berdichevets I, Kozhekbaeva Z, Fesenko D, Kurbatova O, 
et al. Microarray-Based Detection of CYP1A1, CYP2C9, CYP2C19, CYP2D6, GSTT1, GSTM1, MTHFR, MTRR, NQO1, NAT2, HLA-DQA1, and ABO Allele Frequencies in Native Russians. Genet Test Mol Biomarkers (2010) 14 (3)329342. doi:10.1089/gtmb.2009.0158

195. Correia C, Santos P, Coutinho AM, Vicente AM. Characterization of pharmacogenetically relevant CYP2D6 and ABCB1 gene polymorphisms in a Portuguese population sample. Cell Biochem Funct (2009) 27 (4)251-255. doi:10.1002/cbf.1561

196. Ragia G, Arvanitidis KI, Tavridou A, Manolopoulos VG. Need for reassessment of reported CYP2C19 allele frequencies in various populations in view of CYP2C19*17 discovery: the case of Greece. Pharmacogenomics (2009) 10 (1)43-49. doi:10.2217/14622416.10.1.43

197. Bertrand-Thiébault C, Berrahmoune H, Thompson A, Marie B, Droesch S, Siest G, et al. Genetic Polymorphism of CYP2C19 Gene in the Stanislas Cohort. A link with Inflammation. Ann Hum Genet (2008) 72 (2)178-183. doi:10.1111/j.1469-1809.2007.00417.x

198. Crescenti A, Mas S, Gassó P, Baiget M, Bernardo M, Lafuente A. Simultaneous genotyping of CYP2D6*3, *4, *5 AND *6 polymorphisms in a Spanish population through multiplex long polymerase chain reaction and minisequencing multiplex single base extension analysis. Clin Exp Pharmacol Physiol (2007) 34 (10)992-997. doi:10.1111/j.1440-1681.2007.04665.x

199. Hilli J, Rane A, Lundgren S, Bertilsson L, Laine K. Genetic polymorphism of cytochrome P450s and P-glycoprotein in the Finnish population. Fundam Clin Pharmacol (2007) 21 (4)379-386. doi:10.1111/j.1472-8206.2007.00494.x

200. Menoyo A, del Rio E, Baiget M. Characterization of variant alleles of cytochrome CYP2D6 in a Spanish population. Cell Biochem Funct (2006) 24 (5)381-385. doi:10.1002/cbf.1258

201. Rasmussen JO, Christensen M, Svendsen JM, Skausig O, Hansen EL, Nielsen $\mathrm{K}$ a. CYP2D6 gene test in psychiatric patients and healthy volunteers. Scand J Clin Lab Invest (2006) 66 (2)129-136. doi:10.1080/00365510500469702

202. Halling J, Petersen MS, Damkier P, Nielsen F, Grandjean $P$, Weihe $P$, et al. Polymorphism of CYP2D6, CYP2C19, CYP2C9 and CYP2C8 in the Faroese population. Eur J Clin Pharmacol (2005) 61 (7)491-497. doi:10.1007/s00228005-0938-1 
203. Scordo MG, Caputi AP, D'Arrigo C, Fava G, Spina E. Allele and genotype frequencies of CYP2C9, CYP2C19 and CYP2D6 in an Italian population. Pharmacol Res (2004) 50 (2)195-200. doi:10.1016/j.phrs.2004.01.004

204. Gaikovitch EA, Cascorbi I, Mrozikiewicz PM, Brockmöller J, Frötschl R, Köpke $\mathrm{K}$, et al. Polymorphisms of drug-metabolizing enzymes CYP2C9, CYP2C19, CYP2D6, CYP1A1, NAT2 and of P-glycoprotein in a Russian population. Eur J Clin Pharmacol (2003) 59 (4)303-312. doi:10.1007/s00228-003-0606-2

205. Zackrisson A-L, Lindblom B. Identification of CYP2D6 alleles by single nucleotide polymorphism analysis using pyrosequencing. Eur J Clin Pharmacol (2003) 59 (7)521-526. doi:10.1007/s00228-003-0654-7

206. Tamminga W, Wemer J, Oosterhuis B, de Zeeuw R, de Leij L, Jonkman J. The prevalence of CYP2D6 and CYP2C19 genotypes in a population of healthy Dutch volunteers. Eur J Clin Pharmacol (2001) 57 (10)717-722. doi:10.1007/s002280100359

207. Duzhak T, Mitrofanov D, Ostashevskii V, Gutkina N, Chasovnikova O, Posukh $O$, et al. Genetic polymorphisms of CYP2D6, CYP1A1, GSTM1 and p53 genes in a unique Siberian population of Tundra Nentsi. Pharmacogenetics (2000) 10 (6)531-537. doi:10.1097/00008571-200008000-00006

208. Hoskins JM, Shenfield GM, Gross AS. Relationship between proguanil metabolic ratio and CYP2C19 genotype in a Caucasian population. Br J Clin Pharmacol (1998) 46 (5)499-504. doi:10.1046/j.1365-2125.1998.00807.x

209. Ruas JL, Lechner MC. Allele frequency of CYP2C19 in a Portuguese population. Pharmacogenetics (1997) 7 (4)333-335. doi:10.1097/00008571199708000-00009

210. Sachse C, Brockmöller J, Bauer S, Roots I. Cytochrome P450 2D6 variants in a Caucasian population: allele frequencies and phenotypic consequences. Am J Hum Genet (1997) 60 (2)284-95. doi:10.1158/1078-0432.CCR-16-2809

211. Akhmedova SN, Pushnova EA, Anisimov S, Bogdanova LA, Bova LK, Schwartz El. CYP2D6 Genotyping in a Russian Population Using a Novel Approach for Identification of the CYP2D6A Mutation. Biochem Mol Med (1996) 58 (2)234236. doi:10.1006/bmme.1996.0054

212. Albuquerque J, Ribeiro C, Naranjo MEG, Llerena A, Grazina M. Characterization of CYP2D6 genotypes and metabolic profiles in the Portuguese population: pharmacogenetic implications. Per Med (2013) 10 (7)709-718. doi:10.2217/pme.13.56

213. Caccamo D, Cesareo E, Mariani S, Raskovic D, lentile R, Currò M, et al. 
Xenobiotic sensor- and metabolism-related gene variants in environmental sensitivity-related illnesses: a survey on the Italian population. Oxid Med Cell Longev (2013) 2013831969. doi:10.1155/2013/831969

214. Barañska M, Dziankowska-bartkowiak B, Waszczykowska E, Rychlik-sych M, Skrêtkowicz J. Significance of genetic polymorphism of CYP2D6 in the pathogenesis of systemic sclerosis. Pharmacoglogical Reports (2012) 64336342.

215. Nyírő G, Inczédy-Farkas G, Reményi V, Gál A, Pál Z, Molnár MJ. The effect of the CYP 2C19*2 polymorphism on stroke care. Acta Physiol Hung (2012) 99 (1)33-9. doi:10.1556/APhysiol.99.2012.1.4

216. Pedersen RS, Christensen MMH, Brøsen K. Linkage disequilibrium between the CYP2C19*17 allele and other clinically important CYP2C allelic variants in a healthy Scandinavian population. Eur J Clin Pharmacol (2012) 68 (10)14631464. doi:10.1007/s00228-012-1272-z

217. Rideg O, Háber Á, Botz L, Szücs F, Várnai R, Miseta A, et al. Pilot study for the characterization of pharmacogenetically relevant CYP2D6, CYP2C19 and $A B C B 1$ gene polymorphisms in the Hungarian population. Cell Biochem Funct (2011) 29 (7)562-568. doi:10.1002/cbf.1788

218. Adrian A, Daniela C, Axente Gl, lonut O, Flavian R, Anamaria G. Detection of CYP2D6*6 allele by real time polymerase chain reaction in Romanian population. Farmacia (2010) 58 (3)353-361. Available at:

http://www.revistafarmacia.ro/20103/issue32010art12.pdf\%5Cnhttp://ovidsp .ovid.com/ovidweb.cgi? T=JS\&PAGE $=$ reference $\& D=$ emed9\&NEWS $=N \& A N=$ 2010353680

219. Berg ND, Berg Rasmussen $H$, Linneberg A, Brasch-Andersen C, Fenger M, Dirksen A, et al. Genetic susceptibility factors for multiple chemical sensitivity revisited. Int J Hyg Environ Health (2010) 213 (2)131-139.

doi:10.1016/j.jjheh.2010.02.001

220. De Luca C, Scordo MG, Cesareo E, Pastore S, Mariani S, Maiani G, et al. Biological definition of multiple chemical sensitivity from redox state and cytokine profiling and not from polymorphisms of xenobiotic-metabolizing enzymes. Toxicol Appl Pharmacol (2010) 248 (3)285-292.

doi:10.1016/j.taap.2010.04.017 
221. Pedersen RS, Brasch-Andersen C, Sim SC, Bergmann TK, Halling J, Petersen $\mathrm{MS}$, et al. Linkage disequilibrium between the CYP2C19*17 allele and wildtype CYP2C8 and CYP2C9 alleles: Identification of CYP2C haplotypes in healthy Nordic populations. Eur J Clin Pharmacol (2010) 66 (12)1199-1205. doi:10.1007/s00228-010-0864-8

222. Buzková $\mathrm{H}$, Pechandová K, Slanař O, Perlík F. Frequency of single nucleotide polymorphisms of CYP2D6 in the Czech population. Cell Biochem Funct (2008) 26 (1)76-81. doi:10.1002/cbf.1402

223. Fernández-Santander A, Santiago C, Díez-Durán S, González M, de Castro E, Guijarro J, et al. Identification of CYP2D6 null variants among long-stay, chronic psychiatric inpatients: Is it strictly necessary?. Hum Psychopharmacol (2008) 23 (6)533-536. doi:10.1002/hup.943

224. Makeeva O, Stepanov V, Puzyrev V, Goldstein DB, Grossman I. Global pharmacogenetics: genetic substructure of Eurasian populations and its effect on variants of drug-metabolizing enzymes. Pharmacogenomics (2008) 9 (7)847-868. doi:10.2217/14622416.9.7.847

225. Wijnen PAHM, Drent M, Nelemans PJ, Kuijpers PMJC, Koek GH, Neef C, et al. Role of Cytochrome P450 Polymorphisms in the Development of Pulmonary Drug Toxicity. Drug Saf (2008) 31 (12)1125-1134. doi:10.2165/0002018200832120-00008

226. Oliveira E, Marsh S, van Booven DJ, Amorim A, Prata MJ, McLeod HL. Pharmacogenetically relevant polymorphisms in Portugal. Pharmacogenomics (2007) 8 (7)703-12. doi:10.2217/14622416.8.7.703

227. Alonso-Navarro H, Martínez C, García-Martín E, Benito-León J, García-Ferrer I, Vázquez-Torres P, et al. CYP2C19 polymorphism and risk for essential tremor. Eur Neurol (2006) 56 (2)119-23. doi:10.1159/000095702

228. Scordo M, Dahl M, Spina E, Cordici F, Arena M. No association between CYP2D6 polymorphism and Alzheimer's disease in an Italian population. Pharmacol Res (2006) 53 (2)162-165. doi:10.1016/j.phrs.2005.10.005

229. Niewiński P, Patkowski J, Orzechowska-Juzwenko K, Hurkacz M, WolańczykMedrala A, Nittner-Marszalska M. CYP2D6 phenotype versus genotype and the potential risk of allergic diseases. Adv Clin Exp Med (2005) 14 (6)11751180. Available at: https://www.scopus.com/inward/record.uri?eid=2-s2.031444448262\&partnerlD $=40 \& m d 5=e 0 f 58 c d 715 c 3 d a 9 f 401 f 4 a 8439 a 1051 a$ NS -

230. Chou W-H. Comparison of Two CYP2D6 Genotyping Methods and 
Assessment of Genotype-Phenotype Relationships. Clin Chem (2003) 49 (4)542-551. doi:10.1373/49.4.542

231. Agúndez JAG, Gallardo L, Ledesma MC, Lozano L, Rodriguez-Lescure $A$, Pontes JC, et al. Functionally Active Duplications of the CYP2D6 Gene Are More Prevalent among Larynx and Lung Cancer Patients. Oncology (2001) 61 (1)59-63. doi:10.1159/000055354

232. Brown MA, Edwards S, Hoyle E, Campbell S, Laval S, Daly AK, et al. Polymorphisms of the CYP2D6 gene increase susceptibility to ankylosing spondylitis. Hum Mol Genet (2000) 9 (11)1563-1566.

233. Gawronska-Szklarz B, Wójcicki M, Kuprianowicz A, Kedzierska K, Kedzierski M, Górnik W, et al. CYP2D6 and GSTM1 genotypes in a Polish population. Eur J Clin Pharmacol (1999) 55 (5)389-92. Available at: http://www.ncbi.nlm.nih.gov/pubmed/10456489

234. Yamada H, Dahl ML, Lannfelt L, Viitanen M, Winblad B, Sjöqvist F. CYP2D6 and CYP2C19 genotypes in an elderly Swedish population. Eur J Clin Pharmacol (1998) 54 (6)479-81. Available at: http://www.ncbi.nlm.nih.gov/pubmed/9776439

235. Marandi T, Dahl ML, Rägo L, Kiivet R, Sjöqvist F. Debrisoquine and Smephenytoin hydroxylation polymorphisms in a Russian population living in Estonia. Eur J Clin Pharmacol (1997) 53 (3-4)257-60. Available at: http://www.ncbi.nlm.nih.gov/pubmed/9476041

236. Ruas JL, Lechner MC. Allele frequency of CYP2C 19 in a Portuguese population. Pharmacogenetics (1997) 7 (4)333-5. Available at: http://www.ncbi.nlm.nih.gov/pubmed/9295062

237. Ladona M, Abildua R, Ladero J, Roman J, Plaza M, Agundez J, et al. CYP2D6 genotypes in Spanish women with breast cancer. Cancer Lett (1996) 9923-28.

238. Marandi T, Dahl ML, Kiivet RA, Rägo L, Sjöqvist F. Debrisoquin and Smephenytoin hydroxylation phenotypes and CYP2D6 genotypes in an Estonian population. Pharmacol Toxicol (1996) 78 (5)303-7. Available at: http://www.ncbi.nlm.nih.gov/pubmed/8737964

239. Agúndez JAG, Ledesma MC, Ladero JM, Benítez J. Prevalence of CYP2D6 gene duplication and its repercussion on the oxidative phenotype in a white population*. Clin Pharmacol Ther (1995) 57 (3)265-269. doi:10.1016/00099236(95)90151-5

240. Brockmöller J, Rost KL, Gross D, Schenkel A, Roots I. Phenotyping of CYP2C19 with enantiospecific HPLC-quantification of $R$ - and S-mephenytoin 
and comparison with the intron4/exon5 G-->A-splice site mutation.

Pharmacogenetics (1995) 5 (2)80-8. Available at:

http://www.ncbi.nlm.nih.gov/pubmed/7663532

241. Agúndez JAG, Martínez C, Ledesma MC, Ladona MG, Ladero JM, Benítez J. Genetic basis for differences in debrisoquin polymorphism between a spanish and other white populations. Clin Pharmacol Ther (1994) 55 (4)412-417. doi:10.1038/clpt.1994.50

242. Tefre $T$, Daly AK, Armstrong $M$, Leathart JB, Idle JR, Brøgger A, et al. Genotyping of the CYP2D6 gene in Norwegian lung cancer patients and controls. Pharmacogenetics (1994) 4 (2)47-57. Available at: http://www.ncbi.nlm.nih.gov/pubmed/8081413

243. Graf T, Broly F, Hoffmann F, Probst M, Meyer UA, Howald H. Prediction of phenotype for acetylation and for debrisoquine hydroxylation by DNA-tests in healthy human volunteers. Eur J Clin Pharmacol (1992) 43 (4)399-403. Available at: http://www.ncbi.nlm.nih.gov/pubmed/1451720

244. Broly F, Gaedigk A, Heim M, Eichelbaum M, Morike K, Meyer UA. Debrisoquine/Sparteine Hydroxylation Genotype and Phenotype: Analysis of Common Mutations and Alleles of CYP2D6 in a European Population. DNA Cell Biol (1991) 10 (8)545-558. doi:10.1089/dna.1991.10.545

245. Mirzaev KB, Sychev DA, Ryzhikova KA, Konova OD, Mammaev SN, Gafurov DM, et al. Genetic Polymorphisms of Cytochrome P450 Enzymes and Transport Proteins in a Russian Population and Three Ethnic Groups of Dagestan. Genet Test Mol Biomarkers (2017) 21 (12)747-753. doi:10.1089/gtmb.2017.0036

246. Sychev D, Shuev G, Suleymanov S, Ryzhikova K, Mirzaev K, Grishina E, et al. Comparison of CYP2C9, CYP2C19, CYP2D6, ABCB1, and SLCO1B1 genepolymorphism frequency in Russian and Nanai populations. Pharmgenomics Pers Med (2017) Volume1093-99. doi:10.2147/PGPM.S129665

247. Barańska M, Rychlik-Sych M, Kaszuba A, Dziankowska-Bartkowiak B, Skrętkowicz J, Waszczykowska E. Genetic polymorphism of CYP2D6 in patients with systemic lupus erythematosus and systemic sclerosis. Autoimmunity (2016) 6934 (February)1-6. doi:10.3109/08916934.2015.1134508

248. Naranjo MEG, de Andrés F, Delgado A, Cobaleda J, Peñas-Lledó EM, LLerena A. High frequency of CYP2D6 ultrarapid metabolizers in Spain: controversy about their misclassification in worldwide population studies. Pharmacogenomics J (2016) 16 (5)485-490. doi:10.1038/tpj.2016.47 
249. Pietarinen P, Tornio A, Niemi M. High Frequency of CYP2D6 Ultrarapid Metabolizer Genotype in the Finnish Population. Basic Clin Pharmacol Toxicol (2016) 119 (3)291-296. doi:10.1111/bcpt.12590

250. Rychlik-Sych M, Barańska M, Wojtczak A, Skrętkowicz J, Żebrowska A, Waszczykowska $\mathrm{E}$. The impact of the CYP2D6 gene polymorphism on the risk of pemphigoid. Int J Dermatol (2015) 54 (12)1396-1401. doi:10.1111/ijd.12967

251. Weber A, Szalai R, Sipeky C, Magyari L, Melegh M, Jaromi L, et al. Increased prevalence of functional minor allele variants of drug metabolizing CYP2B6 and CYP2D6 genes in Roma population samples. Pharmacol Reports (2015) 67 (3)460-464. doi:10.1016/j.pharep.2014.11.006

252. Dudarewicz M, Rychlik-Sych M, Barańska M, Wojtczak A, Trzciński R, Dziki A, et al. Significance of the genetic polymorphism of CYP2D6 and NAT2 in patients with inflammatory bowel diseases. Pharmacol Reports (2014) 66 (4)686-690. doi:10.1016/j.pharep.2014.04.002

253. Kuhlmann JB, Wensing G, Kuhlmann J. Correlation of genotype, phenotype, and mRNA expression of CYP2D6 and CYP2C19 in peripheral blood leukocytes (PBLs). Int J Clin Pharmacol Ther (2014) 52 (02)143-150. doi:10.5414/CP201966

254. Tervasmäki A, Winqvist R, Jukkola-Vuorinen A, Pylkäs K. Recurrent CYP2C19 deletion allele is associated with triple-negative breast cancer. BMC Cancer (2014) 14 (1)1-7. doi:10.1186/1471-2407-14-902

255. Dahl M-L, Johansson I, Palmertz MP, Ingelman-Sundberg M, Sjöqvist F. Analysis of the CYP2D6 gene in relation to debrisoquin and desipramine hydroxylation in a Swedish population. Clin Pharmacol Ther (1992) 51 (1)1217. doi:10.1038/clpt.1992.2

256. Dlugauskas E, Strumila R, Lengvenyte A, Ambrozaityte L, Dagyte E, Molyte A, et al. Analysis of Lithuanian CYP2D6 polymorphism and its relevance to psychiatric care of the local population. Nord J Psychiatry (2019) 73 (1)31-35. doi:10.1080/08039488.2018.1548648

257. Sałagacka-Kubiak A, Żebrowska-Nawrocka M, Jeleń A, Mirowski M, Balcerczak E. CYP2C19*2 polymorphism in Polish peptic ulcer patients. Pharmacol Reports (2019) 71 (2)272-275. doi:10.1016/j.pharep.2018.12.011

258. Belmonte $C$, Ochoa $D$, Román $M$, Saiz-Rodríguez $M$, Wojnicz A, GómezSánchez $\mathrm{Cl}$, et al. Influence of CYP2D6, CYP3A4, CYP3A5 and ABCB1 Polymorphisms on Pharmacokinetics and Safety of Aripiprazole in Healthy 
Volunteers. Basic Clin Pharmacol Toxicol (2018) 122 (6)596-605. doi:10.1111/bcpt.12960

259. Reisberg S, Krebs K, Lepamets M, Kals M, Mägi R, Metsalu K, et al. Translating genotype data of 44,000 biobank participants into clinical pharmacogenetic recommendations: challenges and solutions. Genet Med (2019) 21 (6)1345-1354. doi:10.1038/s41436-018-0337-5

260. Zhou Y, Lauschke VM. Comprehensive overview of the pharmacogenetic diversity in Ashkenazi Jews. J Med Genet (2018) 55 (9)617-627. doi:10.1136/jmedgenet-2018-105429

261. Hočevar K, Maver A, Peterlin B. Actionable Pharmacogenetic Variation in the Slovenian Genomic Database. Front Pharmacol (2019) 10 (March)1-11. doi:10.3389/fphar.2019.00240

262. Sameer A-El, Amany GM, Abdela AA, Fadel SA. CYP2C19 genotypes in a population of healthy volunteers and in children with hematological malignancies in Gaza Strip. Can J Clin Pharmacol (2009) 16 (1)e156-62. Available at: http://www.ncbi.nlm.nih.gov/pubmed/19193970

263. Koseler A, Ilcol YO, Ulus IH. Frequency of Mutated Allele CYP2D6*4 in the Turkish Population. Pharmacology (2007) 79 (4)203-206. doi:10.1159/000100959

264. Zand N, Tajik N, Moghaddam AS, Milanian I. Genetic polymorphisms of cytochrome P450 enzymes 2C9 and 2C19 in a healthy Iranian population. Clin Exp Pharmacol Physiol (2007) 34 (1-2)102-105. doi:10.1111/j.14401681.2007.04538.x

265. Aydin M, Hatirnaz O, Erensoy N, Ozbek U. CYP2D6 and CYP1A1 mutations in the Turkish population. Cell Biochem Funct (2005) 23 (2)133-135. doi:10.1002/cbf.1222

266. Luo H, Aloumanis V, Lin K, Gurwitz D, Wan YY. Polymorphisms of CYP2C19 and CYP2D6 in Israeli ethnic groups. Am J Pharmacogenomics (2004) 4 (6)395-401. Available at: http://www.ncbi.nlm.nih.gov/pubmed/15651900

267. Aynacioglu A, Sachse C, Bozkurt A, Kortunay S, Nacak M, Schroder T, et al. Low frequency of defective alleles of cytochrome P450 enzymes 2C19 and $2 D 6$ in the Turkish population. Clin Pharmacol Ther (1999) 66 (2)185-192. doi:10.1053/cp.1999.v66.100072001

268. Sviri S, Shpizen S, Leitersdorf E, Levy M, Caraco Y. Phenotypic-genotypic analysis of CYP2C19 in the Jewish Israeli population. Clin Pharmacol Ther (1999) 65 (3)275-282. doi:10.1016/S0009-9236(99)70106-2 
269. Nassar S, Amro O, Abu-Rmaileh H, Alshaer I, Korachi M, Ayesh S. ABCB1 C3435T and CYP2C19*2 polymorphisms in a Palestinian and Turkish population: A pharmacogenetic perspective to clopidogrel. Meta Gene (2014) 2 (1)314-319. doi:10.1016/j.mgene.2014.01.009

270. Al-Dosari MS, Al-Jenoobi Fl, Alkharfy KM, Alghamdi AM, Bagulb KM, Parvez MK, et al. High prevalence of CYP2D6*41 (G2988A) allele in Saudi Arabians. Environ Toxicol Pharmacol (2013) 36 (3)1063-1067. doi:10.1016/j.etap.2013.09.008

271. Al-Jenoobi Fl, Alkharfy KM, Alghamdi AM, Bagulb KM, Al-Mohizea AM, AlMuhsen S, et al. CYP2C19 Genetic Polymorphism in Saudi Arabians. Basic Clin Pharmacol Toxicol (2013) 112 (1)50-54. doi:10.1111/j.17427843.2012.00919.x

272. Serin A, Canan H, Alper B, Gulmen. M. The frequencies of mutated alleles of CYP2D6 gene in a Turkish population. Forensic Sci Int (2012) 222 (1-3)332334. doi:10.1016/j.forsciint.2012.07.012

273. Erden G, Acar FS, Inal EE, Soydas AO, Ozoran K, Bodur H, et al. Frequency of mutated allele CYP2D6*4 in the Turkish ankylosing spondylitis patients and healthy controls. Rheumatol Int (2009) 29 (12)1431-1434. doi:10.1007/s00296-009-0874-y

274. Gutman G, Morad T, Peleg B, Peretz C, Bar-Am A, Safra T, et al. CYP1A1 and CYP2D6 Gene Polymorphisms in Israeli Jewish Women With Cervical Cancer. Int J Gynecol Cancer (2009) 19 (8)1300-1302. doi:10.1111/IGC.0b013e3181b9fa5d

275. Homaei-Shandiz F, Brook A, Tavakol Afshari J, Mohammad Pour AH, Ganjali $\mathrm{R}$, Morad Abbassi Fuladi J, et al. Study the frequency of CYP2D6*4 null allele in Iranian population. Pharmacol 3 (2009) 31003-1007.

276. Kortunay S, Bozkurt A, Bathum L, Basci NE, Calguneri M, Brosen K, et al. CYP2C19 genotype does not represent a genetic predisposition in idiopathic systemic lupus erythematosus. Ann Rheum Dis (1999) 58 (3)182-185. doi:10.1136/ard.58.3.182

277. McLellan RA, Oscarson M, Seidegård J, Evans DA, Ingelman-Sundberg M. Frequent occurrence of CYP2D6 gene duplication in Saudi Arabians. Pharmacogenetics (1997) 7 (3)187-91. Available at: http://www.ncbi.nlm.nih.gov/pubmed/9241658

278. Hadidi HF, Cholerton S, Monkman SC, Armstrong M, Irshaid YM, Rawashdeh $\mathrm{NM}$, et al. Debrisoquine 4-hydroxylation (CYP2D6) polymorphism in 


\section{Supplemental references}

Jordanians. Pharmacogenetics (1994) 4 (3)159-61. Available at:

http://www.ncbi.nlm.nih.gov/pubmed/7920696

279. Arici M, Özhan G. CYP2C9, CYPC19 and CYP2D6 gene profiles and gene susceptibility to drug response and toxicity in Turkish population. Saudi Pharm J (2017) 25 (3)376-380. doi:10.1016/j.jsps.2016.09.003

280. Barlas IÖ, Sezgin O, Dandara C, Türköz G, Yengel E, Cindi Z, et al. Harnessing Knowledge on Very Important Pharmacogenes CYP2C9 and CYP2C19 Variation for Precision Medicine in Resource-Limited Global Conflict Zones. Omi A J Integr Biol (2016) 20 (10)604-609. doi:10.1089/omi.2016.0133

281. Ghasemi Z, Hashemi M, Ejabati M, Ebrahimi SM, Manjili HK, Sharafi A, et al. Development of a high-resolution melting analysis method for CYP2C19*17 genotyping in healthy volunteers. Avicenna J Med Biotechnol (2016) 8 (4)193-199.

282. Tabari RG, Marjani A, Ataby OA, Mansourian AR, Samai NM. Genetic Polymorphism of Cytochrome p450 (2C19) Enzyme in Iranian Turkman Ethnic Group. Oman Med J (2013) 28 (4)237-44. doi:10.5001/omj.2013.69

283. Taskin B, Percin FE, Ergun MA. Investigation of CYP2D6 Gene Polymorphisms in Turkish Population. Psychopharmacol Bull (2016) 46 (1)67-72. Available at: http://www.ncbi.nlm.nih.gov/pubmed/27738374

284. Yasin S, Tahtamouni L, Al-Khateeb R, Abdellatif R, Al-Mazaydeh Z, AlEmerieen A, et al. Screening for CYP2C19 Gene variants in a healthy Jordanian population. Trop J Pharm Res (2017) 15 (12)2745. doi:10.4314/tjpr.v15i12.30

285. Kamalidehghan $B$, Vejdandoust $F$, Bagheri $A$, Houshmand $M$, Azadfar $P$, Akbari $L$, et al. Prevalence of the CYP2D6*10(C100T), *4(G1846A), and *14(G1758A) alleles among Iranians of different ethnicities. Drug Des Devel Ther (2015)2627. doi:10.2147/DDDT.S79709

286. Payan M, Tajik N, Rouini MR, Ghahremani MH. Genotype and allele frequency of CYP2C19*17 in a healthy Iranian population. Med J Islam Repub Iran (2015) 29 (1)269. Available at:

http://www.ncbi.nlm.nih.gov/pubmed/26793660

287. Uckun Z, Baskak B, Ozel-Kizil ET, Ozdemir H, Devrimci Ozguven H, Suzen HS. The impact of CYP2C19 polymorphisms on citalopram metabolism in patients with major depressive disorder. J Clin Pharm Ther (2015) 40 (6)672-679. doi:10.1111/jcpt.12320

288. Dehbozorgi M, Kamalidehghan B, Hosseini I, Dehghanfard Z, Sangtarash M, 
Firoozi M, et al. Prevalence of the CYP2C19*2 (681 G\&gt;A), *3 (636 G\&gt;A) and ${ }^{*} 17(-806 \mathrm{C} \& g t ; T)$ alleles among an Iranian population of different ethnicities. Mol Med Rep (2018) 17 (3)4195-4202. doi:10.3892/mmr.2018.8377

289. Hashemizadeh Z, Malek-Hosseini SA, Badiee P. Prevalence of CYP2C19 Genetic Polymorphism among Normal People and Patients with Hepatic Diseases. Int J organ Transplant Med (2018) 9 (1)27-33. Available at: http://journals.aace.com/doi/abs/10.4158/EP12130.OR

290. Lotfi F, Bahrehmand F, Vaisi-Raygani A, Khodarahmi R, Tanhapour M, Kiani A, et al. Cytochrome P450 (CYP450,2D6*A), N-Acetyltransferase-2 (NAT2*7, A) and Multidrug Resistance 1 (MDR1 3435 T) Alleles Collectively Increase Risk of Ulcerative Colitis. Arch Iran Med (2018) 21 (11)530-535. Available at: http://www.ncbi.nlm.nih.gov/pubmed/30551694

291. Pourkarami Z, Sangtarash MH, Jafarzadeh N, Poursina Z, Izanloo A, Houshmand M. Genetic polymorphisms of CYP2D6*41 in different ethnicities of Iranian population. Gazz Med Ital (2018) 177 (4)158-164. doi:10.23736/S0393-3660.17.03508-2

292. Saeed LH, Mayet AY. Genotype-Phenotype Analysis of CYP2C19 in Healthy Saudi Individuals and its Potential Clinical Implication in Drug Therapy. Int J Med Sci (2013) 10 (11)1497-1502. doi:10.7150/ijms.6795

293. Yousef A-M, Bulatova NR, Newman W, Hakooz N, Ismail S, Qusa H, et al. Allele and genotype frequencies of the polymorphic cytochrome $P 450$ genes (CYP1A1, CYP3A4, CYP3A5, CYP2C9 and CYP2C19) in the Jordanian population. Mol Biol Rep (2012) 39 (10)9423-9433. doi:10.1007/s11033-0121807-5

294. Zihlif M, Imraish A, Irshaid YM. Frequency of Certain Single-Nucleotide Polymorphisms and Duplication of CYP2D6 in the Jordanian Population. Genet Test Mol Biomarkers (2012) 16 (10)1201-1205.

doi:10.1089/gtmb.2012.0122

295. Hashemi-Soteh SMB, Sarzare F, Merat F, Salehifar E, Shiran M-R. Frequencies of Three CYP2D6 Nonfunctional Alleles (CYP2D6*3, *4, and *6) Within an Iranian Population (Mazandaran). Genet Test Mol Biomarkers (2011) 15 (11)821-825. doi:10.1089/gtmb.2011.0033

296. Djaffar Jureidini I, Chamseddine N, Keleshian S, Naoufal R, Zahed L, Hakime N. Prevalence of CYP2C19 polymorphisms in the Lebanese population. Mol Biol Rep (2011) 38 (8)5449-5452. doi:10.1007/s11033-011-0700-y 


\section{Supplemental references}

297. Kouhi H, Hamzeiy H, Barar J, Asadi M, Omidi Y. Frequency of Five Important CYP2D6 Alleles Within an Iranian Population (Eastern Azerbaijan). Genet Test Mol Biomarkers (2009) 13 (5)665-670. doi:10.1089/gtmb.2009.0009

298. Hsu H-L, Woad KJ, Woodfield DG, Helsby NA. A high incidence of polymorphic CYP2C19 variants in archival blood samples from Papua New Guinea. Hum Genomics (2008) 3 (1)17. doi:10.1186/1479-7364-3-1-17

299. Griese E-U, llett KF, Kitteringham NR, Eichelbaum M, Powell H, Spargo RM, et al. Allele and genotype frequencies of polymorphic cytochromes P4502D6, 2C19 and 2E1 in Aborigines from Western Australia. Pharmacogenetics (2001) 11 (1)69-76. doi:10.1097/00008571-200102000-00008

300. Kaneko A, Lum JK, Yaviong L, Takahashi N, Ishizaki T, Bertilsson L, et al. High and variable frequencies of CYP2C19 mutations: medical consequences of poor drug metabolism in Vanuatu and other Pacific islands. Pharmacogenetics (1999)9(5)581-90.

Available at: http://www.ncbi.nlm.nih.gov/pubmed/10591538

301. Montané Jaime LK, Lalla A, Steimer W, Gaedigk A. Characterization of the CYP2D6 gene locus and metabolic activity in Indo- and Afro-Trinidadians: discovery of novel allelic variants. Pharmacogenomics (2013) 14 (3)261-76. doi:10.2217/pgs.12.207

302. Kohlrausch FB, Gama CS, Lobato MI, Belmonte-de-Abreu P, Gesteira A, Barros $F$, et al. Molecular diversity at the CYP2D6 locus in healthy and schizophrenic southern Brazilians. Pharmacogenomics (2009) 10 (9)14571466. doi:10.2217/pgs.09.76

303. LLerena A, Dorado P, Ramírez R, González I, Álvarez M, Peñas-LLedó EM, et al. CYP2D6 genotype and debrisoquine hydroxylation phenotype in Cubans and Nicaraguans. Pharmacogenomics J (2012) 12 (2)176-183. doi:10.1038/tpj.2010.85

304. Dehbozorgi M, Kamalidehghan B, Hosseini I, Dehghanfard Z, Sangtarash M, Firoozi $\mathrm{M}$, et al. Prevalence of the CYP2C19*2 (681 G>A), *3 (636 G>A) and $* 17(-806>T)$ alleles among an Iranian population of different ethnicities. Mol Med Rep (2018) 17 (3)4195-4202. doi:10.3892/mmr.2018.8377 



\section{DANKWOORD}

Het is zover, als ik iets geleerd heb van promoveren dan is het doorzetten. Teksten als 'de aanhouder wint' en 'opgeven is geen optie' zijn nu echt op mij van toepassing. Dat ik nu eindelijk tot een dankwoord en de afronding van dit proefschrift mag komen is enerzijds een kwestie geweest van jarenlang doorbuffelen. Anderzijds heb ik genoten van het eindeloze verdiepen, bedenken, uitrekenen, opschrijven, herstellen, frustreren, opnieuw opschrijven, koffiedrinken, verdiepen, herstellen, opschrijven en zal ik de dagen van "eenzame hyperconcentratie" gaan missen.

Allereerst David Vinkers, jij bent de founder van dit promotietraject en met jouw idee voor een beursaanvraag voor onderzoek naar CYP genotypering op Curaçao ben je de aanstichter van mijn zeven jaar durende promotietraject. Toen ik je leerde kennen op je praktijk aan de Westersingel in Rotterdam (speciaal voor patiënten afkomstig van de voormalig Nederlandse Antillen), voldeed je niet aan mijn verwachting van het prototype psychiater. Je bent ontzettend eigenzinnig, slim en doortastend waardoor ideeën heel snel een concrete vorm aan konden nemen. Ik moest even wennen aan je directe vorm van communiceren maar ik had vrij snel door dat je me regelmatig in de maling probeert te nemen. Je hebt ontzettend veel ambitie en je geeft hier op uiteenlopende manieren vorm aan. Met jouw eeuwige optimisme verdween bij mij ieder gevoel van tegenslag, vaak als sneeuw voor de zon. Voor jou is niets te veel en alles is mogelijk. In combinatie met een goede dosis humor heb je me geïnspireerd voor jouw manier van werken en heb je mijn promotietraject verlicht op momenten dat het zwaar was.

Wijbrand Hoek, als belangrijke schakel in het contact tussen de psychiatrische praktijk van Curaçao en Nederland, was jij vanaf het begin bij dit project betrokken. Je deed me als mijn aanstaand opleider het aanbod om naar Curaçao te gaan. Voor mij een lot uit de loterij! Ik kon weer terug naar het eiland waar ik een jaar eerder met veel plezier gewerkt had, en dat in combinatie met de opleiding tot psychiater. $\mathrm{Ik}$ geloof niet dat ik het beter kon treffen. Deze bijzondere combinatie, helemaal passend bij mijn persoonlijke situatie kenmerkt jouw stijl van begeleiden en opleiden. Je hebt ontzettend veel oog voor interne motivatie en persoonlijke omstandigheden waardoor ik het maximale in mijzelf naar boven kon halen. Je hebt me altijd vertrouwen en tijd gegeven, en me regelmatig voorzien van positieve feedback. Samen met Peter van Harten, een goede vriend van je, vormden jullie een schitterend promotor-team.

Peter, je hebt jarenlang zelf op het eiland als psychiater gewerkt en er zijn al meer dan 10 studies over jouw onderzoeksgegevens gepubliceerd. Je bent een expert op het gebied van bewegingsstoornissen en door jouw bevlogenheid heb ik ontzettend veel over dit onderwerp geleerd. Je bent gedurende mijn gehele promotietraject heel erg betrokken geweest. Je bent betrouwbaar, kritisch, secuur en er is geen moment 
geweest dat ik niet op je kon rekenen voor inhoudelijke feedback of een waardevol inzicht. Ik heb genoten van je aanwezigheid bij de workshops in Berlijn en Maastricht waar de trots op je promovendi duidelijk zichtbaar was! Met Charlie, Jeroen, Mushde en Anne vormden we een gezellig groepje met inhoudelijk een steengoed aanbod op congressen.

De hooggeleerde leden van de lees- en beoordelingscommissie, Prof. van Amelsvoort, Prof. Cahn, Prof. Marcelis en Prof. Slotema wil ik bedanken voor het lezen en beoordelen van mijn proefschrift en het plaatsnemen in de commissie om van gedachten te wisselen over de inhoud van dit proefschrift. Een leescommissie van vrouwen brengt voor mij een mooie balans in een overwegend mannelijk promotieteam. Jullie zijn als vrouw nog steeds in de minderheid op de hogere wetenschappelijke posities (23.1\%) en ik ben erg trots dat het gelukt is om jullie intelligente geesten bij elkaar te krijgen.

Mijn liefde voor het eiland Curaçao is groot en ik heb er ontzettend veel geleerd over leven in een andere cultuur. Frans Heijtel, Micha van de Vorst en zuster Koeiman van psychiaters maatschap de Antillen hebben me hartelijk ontvangen en mee op pad genomen in de wereld achter het toerisme. Ik werd wegwijs in de gevangenis van Bonaire en Curaçao en ging mee op huisbezoek in 'de kunuku'. Samen met Igmar Poulina, inmiddels psychiater maar destijds mede opleideling werd ik wegwijs in de Capriles Kliniek en konden we ons samen boos maken over het feit dat we steevast 'de stagiaires' genoemd werden. Petra Gelan en Michel Dings hielpen ons op weg in de psychiatrische kliniek en steunden onze ingewikkelde verzoeken om het onderzoek goed te laten verlopen. In de Capriles kliniek waren er een heleboel zusters, broeders, begeleiders en patiënten die hebben deelgenomen aan het onderzoek of hebben geholpen het vorm te geven.

Annemiek en Anton, huisgenote en duikmaatje, met jullie heb ik de gekste avonturen beleefd. Op de Anasaweg was het als een echt thuis. Er waren hoogtepunten (een surfsessie en twee duiksessies op één dag) en dieptepunten (een dode rat naast mijn slaapkamerraam). Jullie zijn na 10 jaar weer terug in Nederland en ik ben blij dat je met je slimme hoofd de psychiatrie weer komt versterken!

En niet te vergeten de oldskoolers van de Jorisbaai (Ed, Carola, Martijn, Nienke en Kenny). De plek die jullie gecreëerd hebben op de Jorisbaai is zo onbeschrijfelijk mooi, puur en met jullie erbij gezellig! Het vrije gevoel van een middag windsurfen, biertjes drinken, bbqen en ouwehoeren op deze prachtige verlaten plek zal ik nooit vergeten. Dank jullie wel dat jullie me zo warm en hartelijk ontvangen hebben.

$\mathrm{Na}$ deze onvergetelijk ervaring op Curaçao moest het echte werk, namelijk het analyseren, schrijven, indienen en herschrijven beginnen. Judith Offringa, dank voor alle duizenden puntjes op de i. Zonder jou was het nooit wat met me geworden! Mathijs Deen en Daphne van Hoeken hebben mij qua methodologie en statistiek een 
flink eind verder geholpen. Mario Braakman, dank voor je inspiratie en vertrouwen bij het schrijven van de meta-analyse. Alle mede-opleidelingen van de Parnassia Groep en specifiek mijn jaargenoten, dank ik voor de gezelligheid en het kunnen delen van ervaringen in de eerste fantastische jaren in de psychiatrie. Een opleiding om nooit te vergeten!

In de laatste twee jaar van mijn promotie traject heb ik het voorrecht gehad om bij een fantastische club collega's te werken in de transculturele psychiatrie. Ik wil al mijn lieve collega's van i-psy Utrecht bedanken voor de prettige werksfeer en inspirerende werkomgeving.

Thuis zijn er een heleboel mensen geweest die het promoveren een beetje gemakkelijker gemaakt hebben en als allereerste wil ik daarvoor in het zonnetje zetten: mijn schoonmoeder Jeanne. Jeanne, jij hebt 4 jaar lang ons gezin mede draaiende gehouden, steevast nam jij op woensdag de gehele dag de kinderen en ons huishouden onder je hoede en eerder regel dan uitzondering was je er ook in geval van nood. Jij hebt je kranig geweerd tegen kindergriepjes, poepluiers, hongerige kinderen en oververmoeide volwassenen. Je wilt niet weten hoe dankbaar ik je daarvoor ben!

Ik prijs mezelf gelukkig met een ontzettend grote groep vrienden, familie en schoonfamilie uit Weert, Amsterdam, Leiden, en inmiddels ook Utrecht. Met jullie deel ik vele hobby's en plezierige activiteiten als windsurfen, wielrennen, mountainbiken, snowboarden, biertjes drinken, pandemieën bestrijden, pizza's bakken, vuurtjes stoken, wandelen, strandbezoekjes, vakantie vieren, eindeloos kletsen en filosoferen over het leven. Jullie hebben ieder afzonderlijk mijn leven gekleurd en daarmee een bijdrage geleverd aan dit eindresultaat.

In het bijzonder wil ik noemen Laura, mijn paranimf, sinds ons $12^{\mathrm{e}}$ fietsten we iedere dag samen naar school waardoor we elkaar nogal goed hebben leren kennen. Ondanks een flinke fysieke afstand (Utrecht-Maastricht) voel jij nog steeds feilloos aan hoe het leven er bij mij voorstaat. Ik hou van je gezelligheid en je optimistische kijk op het leven, als ik van iemand heb geleerd wat doorzetten is dan ben jij het wel!

Dan mijn lieve, slimme zusjes Merel, Marleen en Kristijn, op de één of andere manier hebben we alle vier een ongebreidelde interesse in het brein. Toen we klein waren trokken we elkaar de haren uit het hoofd maar inmiddels kunnen we niet zonder elkaar. Ik voel me door jullie ontzettend gesteund en geliefd. Merel, na zoveel jaren als zussen ben ik steeds minder grote en jij steeds minder kleine zus en dat is fijn. Ik ben heel erg blij dat je me als paranimf op mijn promotie kan bijstaan. Ik weet zeker dat als ik flauwval, je me tot de tand toe zal verdedigen!

Mijn ouders, Ben en Liesbeth, aan jullie heb ik een heel warm nest te danken met alle ingrediënten voor een kleurrijke ontwikkeling. Pap, door jou ben ik niet bang om te 
komen waar ik wil zijn. Nog steeds kan ik jou opbellen voor advies en ben je altijd een luisterend oor. Mam, ook jij bent er in voor en tegenspoed. Je bent een krachtig en zorgzaam mens en hierin een voorbeeld voor mij.

En dan tot slot, mijn eigen lieve jonge gezinnetje. Mijn dierbare Jos, alweer 14 jaar samen, ik denk dat ik hier niet gekomen was zonder jou. Allereerst omdat jij voor mij een inspiratiebron bent geweest om te beginnen met het onderzoek. Ik heb veel aan je gehad tijdens het gehele proces, onder andere doordat jij het allemaal al een keer doorlopen had. Maar vooral omdat er met jouw creativiteitstheorie overal een oplossing voor is. Jij bent de kalmte zelve en bij jou ben ik mezelf. Je zou een hele goede psychiater kunnen zijn, maar gelukkig ben je het niet!

Lieve Ise en lieve Kees, jullie zijn een stel deugnieten! Jullie hebben het me eigenlijk alleen maar moeilijker gemaakt en daar ben ik jullie dankbaar voor. Door jullie weet ik wat belangrijk is in het leven! 


\section{CURRICULUM VITRE}

Anne Koopmans

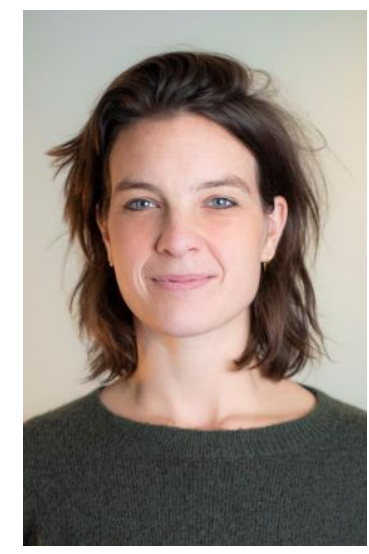

Anne Koopmans (16 juni 1986) is geboren in Almere en getogen in Weert. Na het behalen van haar vwo-diploma (2004) aan het Bisschoppelijk College is ze verhuisd naar Amsterdam. Zij heeft de interdisciplinaire bachelor Bèta Gamma aan de Universiteit van Amsterdam afgerond en in haar tweede studiejaar is zij gestart met de studie geneeskunde aan de Universiteit van Amsterdam. Tijdens deze studie deed zij diverse stages in het buitenland, waaronder in het 's Lands Hospitaal in Suriname, het Thyolo District Hospitaal in Malawi en maakte zij kennis met de wetenschap op het Ernest Gallo research center van de University of California, San Francisco onder leiding van Prof. dr. Dick Swaab. Zij volgde de minor Gender, Seksualiteit en Cultuur en de minor Conflictstudies aan de Universiteit van Amsterdam.

$\mathrm{Na}$ het behalen van haar artsdiploma vertrok zij met haar vriend Jos naar Curaçao om als arts niet-in-opleiding te werken op de afdeling interne geneeskunde in het Sint-Elisabeth Hospitaal. Bij terugkeer werkte zij als arts niet in opleiding bij een FACT-team in Leiden met voornamelijk patiënten met psychotische stoornissen. Zij ging in opleiding tot psychiater bij de Parnassia Groep te Den Haag alwaar zij gelijktijdig aan haar promotietraject begon. Aan het begin van haar opleiding verbleef zij tweemaal drie maanden op Curaçao om onderzoeksgegevens te verzamelen. Haar interesse in andere culturen is gebleven en sinds 2019 is zij werkzaam als psychiater bij i-psy Utrecht waar ze patiënten met psychische problemen en een migratie achtergrond behandelt. $\mathrm{Zij}$ is inmiddels verhuisd naar Utrecht en heeft samen met Jos, twee kinderen; Ise en Kees. 